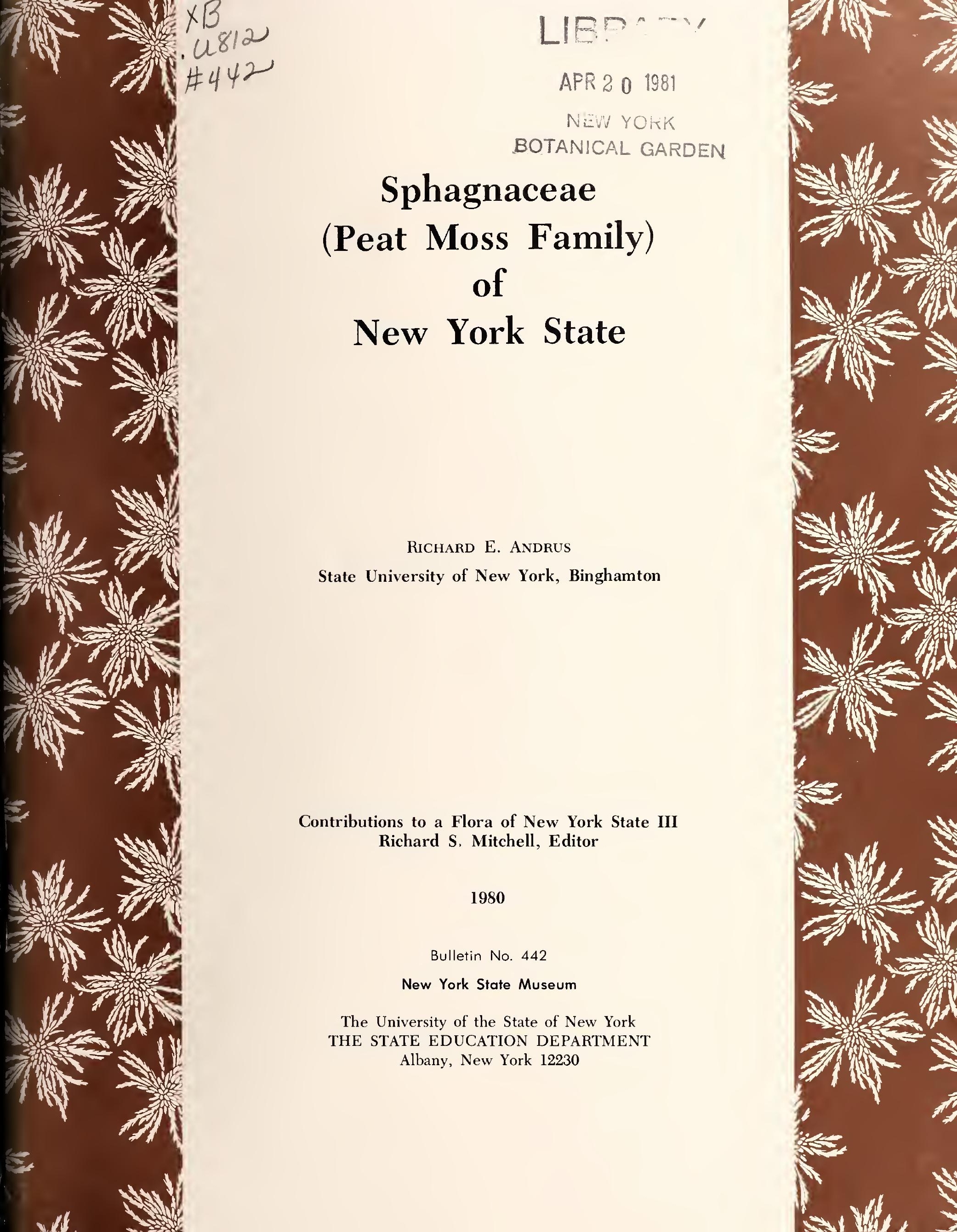


Digitized by the Internet Archive in 2017 with funding from

IMLS LG-70-15-0138-15

https://archive.org/details/bulletinnewyorks4421 newy 


\section{Sphagnaceae \\ (Peat Moss Family) \\ of \\ New York State}

Ruchard E. ANDRUS

State University of New York, Binghamton

Contributions to a Flora of New York State III Richard S. Mitchell, Editor

1980

Bulletin No. 442

New York State Museum

The University of the State of New York THE STATE EDUCATION DEPARTMENT

Albany, New York 12230 


\section{THE UNIVERSITY OF THE STATE OF NEW YORK}

Regents of The University (with years when terms expire)

1988 Willard A. Genrich. LL. B.. L.H.D., LL.D.. Litt.D..

D.C.S. Chancellor

1981 J. EDWARD MEYER. B. A., LL.B.

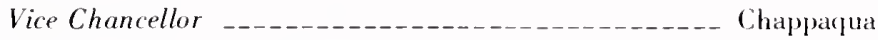

1986 Kenneth B. Clark, A.B., M.S., Ph.D., LL.D., L.H.D.,

D.SC. -

on Hudson

1983 Harold E. Nenconb. B. A.

Owego

1982 EMLYN I. GRIFFith, A.B.. J.D.

Rome

1983 MARY ALICE KENDALl, B.S. Ruchester

1984 Jorge L. Batista, B.A.. J.D., LL.D. Bronx

1982 LOUIS E. YAVNER, LL. 8. New York

1986 Laura Bradley Chodos. B.A.. M.A. Vischer Ferry

1987 Martin C. Barell, B.A., I.A., LL.B. Kings Point

1984 Louise P. Matteoni. B.A., M.A., Ph.D. Bayside

1985 Arlene B. Reed-Delaney, B.A., M.D. Albany

1987 R. Carlos Carballada, B.S. Arcade

1981 Floyd S. LinTon, A.B., M.A. M.P.A. Miller Place

1981 Salvatore J. SClafani, B.S., M.D. Staten Island

President of The University and Commissioner of Eduration GORDON M. AMBACH

Executive Deputy Commissioner of Education JOSEPH J. BLANEY

Deputy Commissioner for Cultural Education ROBERT J. MAURER

Assistant Commissioner for Museum, Science Service, and Historical Services Patrick T. Houlihan

Director, State Science Service HugO JAMNBACK

Chief, Biological Survey Richard H. Monheimer

State Botanist

RICHARD S. MitCHELL 


\section{PREFACE}

OUR GOAL in producing this series is to present a useful and authoritative account of the plants of New York State. This series of contributions is intended to reflect the knowledge and taxonomic opinions of specialists who prepare the manuscripts, while following a generalized format for consistency. Inclusion of ecological, distributional, medical and economic information on each species is also one of our major aims. Habitat referenees, flowering times, pertinent synonymy, etc., apply specifically to New York plants rather than to the entire ranges. Complete illustration should facilitate identification of specimens for those who are not formally trained in botany. Descriptions are original, ordered and as complete as possible to provide sequential cross-referencing.

Distribution maps accompany species of seed plants, ferns, mosses, lichens and some groups of fungi. Maps are based on the master file at the New York State Museum, Albany, and supplemented by available data (specimens examined by the authors) from herbaria housing significant New York collections. Specific data or literature citations for any map may be obtained, on approval, from the Museum.

We hope that these bulletins will serve individuals with interest in the flora, as well as to provide information for State and Federal agencies, conservation organizations, industry and the scientific community. With these works go our hopes for the preservation and wise use of a precious and lifegiving resource - our State's plantlife.

Richard S. Mitchell, Editor

\section{The New York State Flora Committee}

The steering council of the New York State Flora Committee met for the first time on January 19 , 1976, and established as its goals the promotion of study of the State's plant resources and the publication of this series of Museum Bulletins. These contributions will be continually updated after publication for possible incorporation into larger volumes at a later date.

Members of the council at the time of this publication are:

Richard S. Mitchell, Chairman, State Botanist, N.Y. State Museum, Albany (Vascular Plants) Charles J. Sheviak, Curator of Botany, N.Y. State Museum, Albany (Vascular Plants)

Robert T. Clausen, Cornell University, Ithaca (Vascular Plants)

Edwin H. Ketchledge, College of Environmental Science and Forestry, Syracuse (Bryophytes)

Clark T. Rogerson, New York Botanical Garden, New York (Fungi)

George J. Schumacher, Biology Department, SUNY, Binghamton (Algae) 


\section{CONTENTS}

Preface

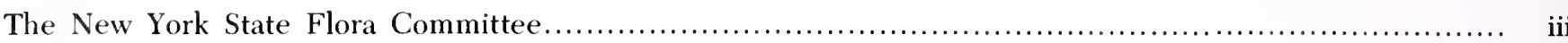

Acknowledgments

Note

Map of Physiographic Provinces

Legend

Introduction

Ecology

Table 1. Mire Types

Peatland Geography.

Economic Significance

Phytogeography

Phytogeographic Patterns.

Table 2. Occurrence of Sphagnum

Morphology

Sphagnum

Key to Sections.

Table 3.

Table 4

Glossary

Literature Cited

Index 


\section{ACKNOWLEDGMENTS}

As this represents a refinement of my doctoral research, very special thanks are due to Edwin H. Ketchledge and James W. Geis for their guidance and moral support during my graduate studies. Although numerous bryologists have contributed to my sphagnological education, special gratitude is due Howard A. Crum, Lewis E. Anderson, Norton G. Miller, Gary L. Smith, and Dale H. Vitt. Literally dozens of herbarium curators have provided assistance, but I am particularly grateful to Robert T. Clausen at Cornell University for making available to me the extensive A. Leroy Andrews herbarium and bryological library. Most of all, however, I owe a huge debt of gratitude to the late Stanley J. Smith of the New York State Museum for his indefatigable collecting and constant encouragement; without him, not only would this work be considerably less detailed in New York phytogeography, but also I might never have gotten involved with these unusual and fascinating mosses. Special thanks to Steve Sierigk who provided most of the habit sketches. The cover art is by Kathryn M. Conway.

\section{NOTE}

All geographic distributions reported here, both for New York State and in general, are based on personally verified specimens unless otherwise indicated.

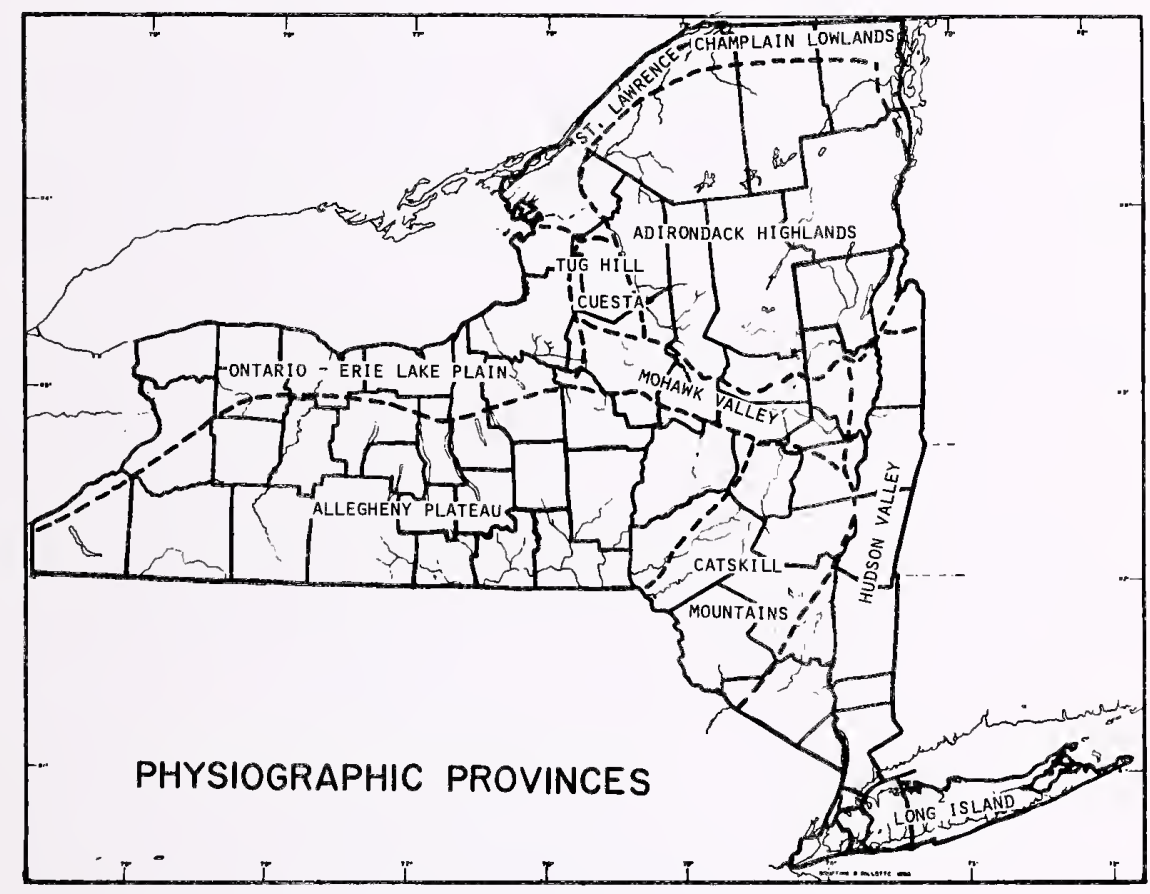




\section{LEGEND}

For all illustrations in this publication the following letter designations apply:

A. Habit sketch

B. Branch leaf from spreading branch

C. Transverse section of branch leaf from spreading branch

D. Convex surface, upper middle region, of branch leaf from spreading branch

DM. Same as D but middle region

DL. Same as D but lower middle region

E. Concave surface, upper middle region, of branch leaf from spreading branch

EM. Same as E but middle region

EL. Same as E but lower middle region

F. Apex of spreading branch leaf

G. Border of spreading branch leaf

H. Cortical cells of spreading branches

I. Stem leaf

J. Stem leaf hyaline cells, upper middle region, convex surface, anisophyllous form

K. Stem leaf hyaline cells, upper middle region, convex surface, hemiisophyllous form

L. Stem leaf hyaline cells, upper middle region, concave surface, anisophyllous form

M. Stem leaf hyaline cells, upper middle region, concave surface, hemiisophyllous form

N. Stem transverse section

O. Stem cortex, surface view

P. Hanging branch leaf, upper middle region, convex surface 


\section{INTRODUCTION}

Of all bryophytes, the Sphagnum or Peat Moss group is certainly the most familiar to biologist and layman alike. Its ecological and economic significance substantially surpasses that of other bryophytes and has made Sphagnum of great interest to ecologists as well as taxonomists. Although the following treatment is limited to the species found in New York State, 46 of the 61 known North American species are represented. Since most of the remaining species are either far northem or limited to westem North America, this flora is applicable over a large geographic area.

\section{ECOLOGY}

Species Ecology. The ecological significance of Sphagnum derives primarily from its ability to grow in wet conditions and acidify its environment. The preference of Sphagnum for wet habitats is well known, and different species occur at characteristic levels with respect to the water table. Species such as Sphagnum cuspidatum and $S$. macrophyllum are well adapted to growing submersed or at water level while S. fallax and S. riparium form carpets slightly above the water table. Others such as S. magellanicum and S. russowii are found higher yet, often on hummock sides, while $S$. nemoreum and $S$. fuscum are often found on tops of hummocks, up to 50 centimeters or more above the water table. The exact factors affecting species distribution with respect to the water table are as yet unknown. It is known, however, that Sphagnum species can hold from 10 to 25 times their dry weight in water (Vitt, Crum \& Snider, 1975) and retain this water for considerable periods. Another important adaptation is the ability of the plants, mainly by virtue of wick branches hanging down the stem, to draw water upward by capillary action to their growing tips.

Perhaps the most striking characteristic of the sphagna is their ability to increase acidity by releasing hydrogen ions in exchange for dissolved cations such as calcium, magnesium, sodium and potassium. The highly acidic environments of most mire habitats are directly attributable to this acidifying action.

The plants function as cation exchangers (Anschutz \& Gessner, 1954) with the exchange matrix consisting of polyuronic acids (Clymo, 1963) found in the cellulose matrix of the cell wall (Craigie \& Maass, 1966). The cation exchange capacity is directly correlated with polyuronic acid content (Clymo, 1963; Spearing, 1972). A strong correlation also exists between polyuronic acid content and optimum height above the water table, with hummock top species having higher amounts than carpet formers (Clymo, 1963; Spearing, 1972). Craigie and Maass (1966), working with species characteristic of richer sites (higher $\mathrm{pH}$ and nutrient concentrations) than those of Clymo or Spearing (ibid), found substantially higher exchange capacities than the latter workers. Species of richer sites would be expected to have higher exchange capacities due to the higher ionic concentrations and $\mathrm{pH}^{\prime}$ s encountered, but more research is needed to clarify this question. Clymo (1963) was able to demonstrate infraspecific variation for $S$. papillosum, with cation exchange capacity increasing both with increasing $\mathrm{pH}$ values and increasing cation concentrations. Thus the species possesses a certain degree of flexibility with respect to chemically varying environments. Ecological Influence. Sphagnum species provide one of the clearest examples of living organisms which can control the metabolism and succession of a community. Their acidifying capabilities contribute to acid peat formation which greatly inhibits decomposition (Wetzel, 1975). Under suitable conditions, this leads to accumulation of deep beds of only partially decomposed peat moss, whose highly acid character preserves both natural and human artifacts. Woolly mammoths and even humans have been almost perfectly preserved after many thousands of years interment in peat bogs.

Sphagnum plants themselves also decay very slowly and can often be identified to species hundreds of years after deposition as peat deposits. Because of this, it is possible to take corings through the peat below the living Sphagnum and determine which different species, if any, have preceded the present ones on that particular site. Using this approach, several kinds of mire successions have been demonstrated. The first of these depends upon the acidifying action of different species. Carefully analyzed peat profiles have revealed a complete successional series from species able to tolerate and acidify neutral waters up to species that thrive in very acid habitats. Mörnsjö (1969) found that a typical southern Swedish mire succession includes the S. contortum stage $\rightarrow$ S. teres stage $\rightarrow$ S. angustifolium stage $\rightarrow$ S. rubellum stage $\rightarrow$ Polytrichum strictum. Each stage has created an environment suitably acidic for the following stage, and peat $\mathrm{pH}$ profiles taken where this kind of succession has occurred show increasing pH values with depth (Kurz, 1928; Pearsall, 1941). Certain Sphagnum species, perhaps because of very strong acidifying capabilities, are more prominent than others in mire succession. Green and Pearson (1968) have noted the aggressiveness of "S. recurvum" (probably S. fallax) in colonizing new areas in English mires. In 
many mires, a similar pattern can be seen along the gradient from the perimeter of the mire, where mineralized soil water is influential, to the center where the soil mineral influx has been taken up by perimeter species, thus allowing more acidophilous species to predominate.

Succession also occurs along a wet-dry gradient. In weakly mineralized systems, the first sphagna to colonize new aquatic habitat are species such as S. cuspidatum, S. torreyanum, and S. macrophyllum which are well adapted to growing submerged. Gradually these are replaced by carpet-forming species such as S. fallax, S. angustifolium and S. recurvum. Succession can then continue on through to hummock formers such as $S$. magellanicum, $S$. nemoreum and $S$. fuscum. In less acid mineralized mires, more minerotrophic species will be found, but the basic pattern still occurs.

Wetland Types. Although sphagna always grow in very moist sites, marked differences exist in the kinds of moist sites that different species inhabit. Geologic, climatıc, and vegetational influences have combined to produce a variety of wetland types, many of which are characterized by distinct Sphagnum floras. A wetland classification scheme, then, can provide valuable insights into Sphagnum ecology. Conversely, knowledge of the Sphagnum flora can also yield useful information about a given wetland.

Extensive literature review and field observation have led to the conclusion that the most useful wetland classification is that generally used throughout Sweden, and the following discussion is based thereon. Special mention may be made of papers by Malmer (1962), Mörnsjö (1969), Persson (1961), and Sjörs (1950a). Sjörs (1959, 1963) has also applied the Swedish mire classification to northern Canadian vegetation. In his work on Minnesota wetlands, Heinselman $(1963,1970)$ developed a peatland classification employing many aspects of the Swedish system but retaining some American terminology. Damman (1977, 1979a) has done valuable work on eastern North American peatlands and their relationship to European vegetation types.

Most New York State sphagna also occur in Sweden, and an abundant Swedish ecological literature on Sphagnum exists (see esp. Sjörs, 1950a, 1950b), Malmer (1959) and Nyholm, (1969). It was possible, by means of field observations of Sphagnum species associations, their vertical distribution and their water supply chemistry, to correlate the ecological distributions of the species common to both New York and Sweden. Within the limits of accuracy that such an approach offers, it appears that all species compared have similar ecological distributions and occur with similar other sphagna in both areas. Comparisons with British (see esp. Tansley, 1939; Gorham, 1953a; Rose, 1953; Gorham and Pearsall, 1956; Ratcliffe and Walker, 1958), French (see esp. Couderc and LeGoff, 1969; Courtejaire, 1963; Touffet, 1968), Russian (Abramova, Savich-Lyubitskaya and Smirnova, 1961), and Japanese (see esp. Horikawa and Suzuki, 1954a, 1954b; Suzuki, 1956a, 1960) literature yields a similar correspondence.

Sphagnum occurs almost exclusively in mires, defined by DuReitz (1954) as wetlands where at least some peat formation is occurring. The mire classification employed in Table 1 is based upon water chemistry and hydrologic criteria and closely reflects variations in vegetation.

Bogs (ombrotrophic mires in the strict sense) are defined as mires where the subsoil water is derived solely from precipitation. In other words, bog vegetation is completely insulated from any nutrient influx via mineral soil water. It should be noted, however, that nutrients may be recycled through the peat profile (Damman, 1978). Low $\mathrm{pH}$ values $(3.0-4.5)$ and small amounts of dissolved minerals, especially calcium ions, are typical.

Raised bogs are characterized by convex cross sections, the centers being higher than the margins. They occur mostly in northern coastal areas with very high rainfall and humidity, although Heinselman (1970) has described the formation of such a bog on a water-table divide in Minnesota. In North America, raised bogs are found in coastal regions of Washington, British Columbia, Alaska, Maine and eastern Canada (Oswald, 1955; Rigg, 1940), but are absent as far south as New York (Damman, 1979b). Typical raised bog sphagna include S. papillosum, S. fuscum, S. lindbergii, S. tenellum and S. rubellum.

Blanket bogs frequent even moister climates than raised bogs (Tansley, 1939) and cover the land continuously, even on slopes. Impeded lateral drainage is not a prerequisite for their formation, since heavy rainfall and high humidity provide a sufficiently moist environment. Due apparently to a greater nutrient influx from the higher rainfall, blanket bogs are less acid than raised bogs (Gorham, 1953b). Though widespread in western Ireland and western Scotland, blanket bogs are rare in North America, being prominent only on the Queen Charlotte Islands of British Columbia. In New York, blanket bog vegetation is found on the alpine summit area of Algonquin Peak (elev. $5114 \mathrm{ft}$.), in the Adirondack Mountains. Extending down gently sloping sides from the summit is a blanket bog vegetation type dominated by S. fuscum and S. nemoreum. Its principal causal factors appear to be the very poor drainage afforded by the massive anorthosite bedrock and the very humid microclimate (even in summer the summit is often covered by cap clouds). 
I. Bog-Water supply strictly atmospheric.

A. Raised bog-Convex in transverse section.

B. Blanket bog-Irregular in transverse section, following land contours.

C. Flat bog-Flat in transverse section.

II. Fen-Water supply influenced by mineral soil ground water.

A. Poor fen-Water supply low in dissolved nutrients and strongly to moderately

acid.

B. Medium fen---Water supply, dissolved nutrients, and acidity intermediate between poor and rich fen.

C. Rich fen-Water supply relatively high in dissolved nutrients and weakly acid to weakly basic.

Flat bogs occur in drier climates than the previous bog types, and are usually located as central portions of larger mire complexes, of which the marginal vegetation is fen influenced by mineral soil water. As their name implies, flat bogs have a surface that appears flat in cross section.

Since there are no obligate bog plants-all characteristic bog species also occur in poor fens (Malmer, 1962)flat bogs must be recognized vegetationally by a lack of obligate fen species. A monotonous hummock-hollow topography typifies flat bogs and, due to the limited number of plants able to tolerate the highly acidic and very weakly mineralized substrate, species diversity is low. In New York, true flat bogs are apparently quite rare. The only one well known to this author occurs as part of an extensive mire complex near Bloomingdale, N.Y. on the northern fringe of the Adirondacks. A large central portion of the mire is a very hummocky, true flat bog with a limited number of sphagna-S. nemoreum, S. rubellum, S. fuscum, S. fallax, S. angustifolium and rarely $S$. cuspidatum.

Any mire in which the subsurface water has any contact with mineral soil is herein considered a fen. Fens are thus always minerotrophic as opposed to the ombrotrophic bogs. The term "bog" or "valley bog" as employed by most British and North American ecologists (see esp. Tansley, 1939; Dansereau and Segadas-Vianna, 1952; Jeglum et al., 1974), refers to any Sphagnum-dominated, peat-forming wetland in an impeded drainage situation, and therefore includes many mires classed as fens by Swedish workers. Conway (1949) has used moss-heath to include a vegetational type dominated by ombrophilous ericaceous plants and ombrotrophic sphagna such as $S$. nemoreum, S. recurvum, S. magellanicum and S. cuspidatum. In the present classification, moss-heaths would be either flat bogs or very poor fens. In Britain, "moss" is also used interchangeably with "bog" in the broader sense.

The earliest fen classification (DuReitz, 1949) included only poor and rich fens. Sjörs (1950a), however, recognized intermediate classes and suspected that a continuum from poor to rich probably existed. Most recent workers separate at least poor, medium and rich fens, with finer subdivisions frequently made. In the investigations to date, New York fens could generally be recognized as poor, medium, or rich and it is felt such a subdivision adequately reflects the current knowledge of mire site preferences for the New York sphagna.

Poor fens have weakly mineralized waters with low pH values, generally between 3.5 and 5.0. Sphagnum species present in New York include the facultative ombrotrophs S. rubellum, S. nemoreum, S. fuscum, S. magellanicum, S. fallax, S. angustifolium and S. cuspidatum as well as a number of other obligate minerotrophs requiring at least a minimal mineral influx. Among the more conspicuous sphagna in the latter category are $S$. papillosum, S. lescurii, S. majus, S. flexuosum, S. torreyanum and S. russowii. In wooded poor fens, S. russowii, S. girgensohnii, S. magellanicum and occasionally S. centrale and S. subtile become prominent.

Poor fens dominate the major New York mire areas of Long Island and the Adirondack Mountains as well as much of the remainder of the State. 
Medium fens present perhaps the most difficult classification problem since they seem to lack specific indicator species. Recognition must come instead from the absence of several of the prominent bog and poor fen species (S. cuspidatum, S. fuscum, S. nemoreum, S. rubellum and S. tenellum) and the presence of several other sphagna also found in rich fens $(S$. centrale, S. henryense, S. palustre, S. imbricatum, S. squarrosum, S. subsecundum, S. teres, and S. warnstorfii).

Prominent medium fen sphagna include S. imbricatum, S. centrale, S. subsecundum, S. teres, S. squarrosum and $S$. fimbriatum. Medium fen $\mathrm{pH}$ values generally range from 4.5 to 6.5 , with waters being somewhat more mineralized than for poor fens.

The most minerotrophic mires are the rich fens. In six New York rich fens sampled, $\mathrm{pH}$ values ranged from 6.0 to 7.8 . Typical rich fen sphagna include $S$. centrale, S. teres, S. contortum and S. warnstorfii, with S. contortum being practically obligate. Other bryophytes such as Campylium stellatum, Tomenthypnum nitens, Catoscopium nigritum and Scorpidium scorpioides as well as the hepatics Trichocolea tomentella and Riccardia pinguis are also important rich fen indicators. Rich fens are not common in New York, but become increasingly common in North America as one progresses northward and inland. Much muskeg is rich fen.

Spring fens may be poor, medium or rich and occur as small mires that have developed around a fresh, flowing water source. In Britain, the term flush is roughly comparable; S. squarrosum, S. fimbriatum, S. girgensohnii, and S. lescurii are often prominent in spring fens in New York.

Sphagnum may also grow in several non-peat-accumulating wetland types. Fen meadows are periodically flooded meadow-like wetlands bordering water courses. Because of flooding, no peat aecumulation can occur. Sphagnum lescurii occasionally occurs here. American and British ecologists often refer to fen meadows as marshes.

Carrs are Alnus and/or Salix dominated wetlands adjoining water courses. Periodic flooding also precludes peat accumulation here; S. fimbriatum, S. palustre and S. imbricatum occur in carrs with some frequency. American ecological literature (Heinselman, 1970; Jeglum et al., 1974) has generally included carrs, along with richer forested fens, as swamps. To British (Tansley, 1939) and Swedish (Mörnsjö, 1969) ecologists, however, a swamp is a rich wetland where the normal summer water level never falis below the soil surface. Swamps in this latter sense do not contain Sphagnum.

\section{PEATLAND GEOGRAPHY}

Of the world's peat reserves, the U.S.A. (excluding Alaska) has $5 \%$, ranking fourth behind the U.S.S.R. (61\%), Finland (10\%) and Canada (9\%) (Olenin, 1968). Although no accurate figures are available, most of the U.S. Sphagnum peat reserves certainly lie in Minnesota and Michigan, with lesser amounts in other northern states including New York and Maine. Overall, about $1 \%$ of the U.S.A. is peatland, outside of Alaska, a signifieant but unknown portion of which is Sphagnum-dominated. By comparison, 32\% of Finland (Kivinen, 1968), 15\% of Sweden and $7 \%$ of the United Kingdom (Moore and Bellamy, 1974) are covered by peatland.

\section{ECONOMIC SIGNIFICANCE}

Sphagnum and its peat have a remarkably diverse range of uses deriving fundamentally from its highly acidic character. Eskimos and Indians have used it for bedding, swaddling and diapering in areas as widely separated as Lapland and Michigan (Crum, 1976). In fact, the anti-bacterial properties of the aeid peat make it quite effective against that bane of parenthood, diaper rash. The great absorbency of dried Sphagnum is also of obvious utility in diapering.

Peat in the broad sense can be of several types. Classification systems vary substantially, but based upon the plant material several types can be recognized. Sphagnum peat, of course, is formed mainly of partially decomposed remains of Sphagnum moss. Highly humid oceanic climates such as those in Ireland, Scotland and the Queen Charlotte Islands of British Columbia especially favor the development of Sphagnum peat. The majority of the world's peat is, however, probably derived principally from sedges of the genus Carex. A smaller but still significant portion originates from non-sphagnous mosses and is usually termed Hypnum peat after the kind of moss that predominates. Some peat, formed in areas where forested mires are important, may also contain a large percentage of woody material. There are also many possible combinations and intergrades of the above types, depending upon the nature of the mire from which the peat has developed. Since natural succession often replaces one type of mire with another, e.g., Carex-dominated with Sphagnum-dominated mires, the same peat deposit may contain several peat types. 
In Ireland and Scotland, where Sphagnum is prominent in peat deposits, peat has been used locally for centuries as a fuel. Sphagnum-dominated peat is apparently preferable as a fuel source. Most of the residents of Ireland live in houses heated by one form or another of peat, ranging from hand cut turf to briquettes (Miller, 1968).

In more rural areas of Ireland, peat has also been used to fire small scale electrical generating plants totaling $387.5 \mathrm{MW}$ and in more remote areas of the Soviet Union, peat has been used in electrical generating stations since 1914 (Moore and Bellamy, 1974). As recently as 1963, 60 U.S.S.R. electric and gas generating plants were using peat as a fuel (Tsuprov and Sokol, 1968), a usage which consumed $70 \%$ of the Soviet peat harvest (Moore and Bellamy, 1974). With recent world energy supply problems, interest in larger scale peat-fueled power stations have developed, but the economics seem largely unfavorable due to the remoteness of most peat deposits and the difficulty of drying peat efficiently.

In the U.S., the Minnesota Gas Company is working on a process to convert peat to synthetic natural gas (Mickelsen, 1976). If economically feasible, a full-scale plant could conceivably produce $25 \%$ of the U.S. current annual use for the next 20 years from 200,000 acres of Minnesota bogs averaging 71/2 feet in thickness.

Peat also lends itself to a variety of other uses. During World War I, a cotton shortage led to widespread usage of sterilized Sphagnum in wound dressings (Crum, 1976). Material from species in section Sphagnum such as S. papillosum and S. palustre was preferred because of its high absorbency, usually exceeding 20 grams of water per gram of plant dry weight.

The use of peat in horticulture is familiar to all; in the U.S. nearly all peat, whether locally harvested or imported, is used for this purpose. For horticultural purposes, Sphagnum peat tends to be superior to other peats due to its higher water-holding capacity, lower mineral ash percentage and higher fiber content. In the U.S. about 15 to $20 \%$ of the peat harvested is Sphagnum peat, and this is employed in such uses as soil improvement, seed germination, potting soils, mixed fertilizer and packaging for flowers and shrubs (Mickelsen, 1976). In the Soviet Union, peat has even been dried and pressed into boards for use as insulation.

Although the use of peat by man is ancient, recent technological advances are finding new uses for it. The high absorbency of peat makes it effective in the treatment of modest oil spills (Hennezel and Coupal, 1972), and its ability to absorb chemicals has proved useful in water pollution control for removing acid dyes (Poots, McKay and Healy, 1976) and toxic metals (Coupal and Lalancette, 1976) from industrial waste waters. Peat-sand filters have also proved to be cheap and effective in small-scale sewage treatment (Mickelsen, 1976).

Because of their ability to retain large quantities of water where they are widespread, peatlands significantly influence hydrology and even climate. In northern Europe and Asia especially, huge amounts of peatland have been reclaimed for agriculture and forest. Properly reclaimed, peatlands can produce good yields of crops and trees, and the reclaimed area may actually produce a steadier water release than an undisturbed mire (Vidal, 1968). A long-term problem results, however, because such reclamation reduces the rate of peat accumulation to below the rate of loss, and eventually the peat substrate will disappear-a problem of great concern to some ecologists (Moore and Bellamy, 1974). A more benign usage of Sphagnum mires is for cranberry production, for here peat accumulation can continue. In New York State, a significant cranberry industry once flourished in the abundant bogs of Long Island's Peconic River drainage basin (Huss, 1977). Cranberry farming went on here from the late 1800 's through the early 1930 's, but declined thereafter due to the Blackheaded Fireworm and problems with the pesticide used to control it. In 1974, the last commercial cranberry bog on Long Island ceased operation. The old Woodhull cranberry bog around Sweezy Pond outside Riverhead is now part of the Suffolk County park system, but the old drainage channels from the cranberry days are still clearly visible. At least one other attempt to reclaim New York State Sphagnum peatlands failed in the 1960's when the voracious appetites of the local deer ended the hopes of converting part of a large Franklin County bog into a lettuce farm.

U.S. peat production totalled 731,000 short tons (ST) in 1974, of which 13,000 ST were classed as "Moss Peat". In addition, about 300,000 ST were imported. New York alone imported 116,000 ST of peat worth $\$ 7,200,000$ in 1974 , most of it coming from Canada into Ogdensburg and Buffalo. New York's own production for 1974 was 18,000 ST worth $\$ 181,000$ mainly from Orange, Westchester and Seneca counties (Heising, 1977).

\section{PHYTOGEOGRAPHY}

New York's exceptionally rich Sphagnum flora results from a fortunate combination of geography and physiography. Between Long Island, with its relatively moderate coastal climate, and the Adirondack Mountains, with a cold boreal climate, a broad range of mire habitats are to be found; these give New York State the largest number of Sphagnum species of any comparably sized area in the world. Because of this great diversity, it is especially worthwhile to look at the phytogeography of the New York species and how they are distributed within the State. 


\section{PHYTOGEOGRAPHIC PATTERNS}

The New York State sphagna fall into several distributional patterns, the general nature of which are discussed by Isoviita (1966). The major overall patterns are related to the affinities of species for humid or continental climates. Continental distributions are clearly concentrated inland, though they are not necessarily completely limited to such areas. In Sphagnum, continental tendencies become more clearcut at southern range extremes, whcre environmental conditions are less favorable than in the central portion of their distribution. The following New York species fit this pattern:
S. centrale
S. platyphyllum
S. contortum
S. majus
S. jensenii

S. angustifolium
S. riparium
S. wulfianum
S. nemoreum
S. fuscum
S. warnstorfii

Sphagna with continental distributional tendencies occur almost exclusively upstate with only S. fuscum and S. angustifolium having any occurrences on Long Island.

A number of species are found predominantly near the coast with sometimes a few scattered occurrences inland, especially at high elevations in the Adirondack Mountains and southern Appalachians. Most of these are basically Atlantic coastal plain endemics (S. portoricense, S. macrophyllum, S. trinitense, S. torreyanum, S. tenerum and S. flavicomans), while the remainder are amphiatlantic (S. strictum, S. pylaesii, S. angermanicum and S. molle). In New York, these species occur almost exclusively on Long Island.

Intermediate between these first two groups is a third group whieh seems limited mainly by the humidity of the climate and in North America is found east of the Mississippi River and west of the Cascade Mountains. In New York, species in this group generally are widespread both upstate and on Long Island. In this group, S. lescurii, S. cuspidatum and S. flexuosum are amphiatlantic while S. palustre, S. papillosum, S. imbricatum, S. tenellum, S. fallax, S. pulchrum, S. rubellum, S. quinquiforium and S. subfulvum are both amphiatlantic and amphipacific. Of the remainder, S. subtile is amphiatlantic and east-pacific, $S$. henryense is west-atlantic and amphipacific while S. recurvum and S. andersonianum are east-atlantic. Sphagnum recurvum could also be treated as simply having an expanded coastal distribution, particularly because of its frequent occurrence in ruderal habitats.

The remaining species have no obvious distributional tendencies related to climatic variables and, given suitable habitat, seem equally likely to occur near the coast or in the continental interior. New York sphagna with such widespread distributional tendencies include S. magellanicum, S. compactum, S. squarrosum, S. teres, S. subsecundum, S. lindbergii, S. fimbriatum, S. girgensohnii and S. russowii. All of these, except for S. lindbergii, occur both upstate and on Long Island. The relative scarcity of S. teres and S. subsecundum on Long Island can be related to two factors: 1) they are both near the southern limits of their distribution and Long Island has a milder climate than upstate, and 2) they both occur mainly in medium to rich fen habitats and such habitats don't exist on Long Island. Sphagnum lindbergii has a much more northerly distribution than the other species in this group and in New York has been collected only in one location as an isolated southern disjunct.

The differences between the categories are, of course, not absolute, and considerable variation can also be found within categories. For example, among the coastal species S. angermanicum and S. flavicomans are more strictly coastal than either $S$. molle or S. torreyanum. In spite of this and other similar inequities, this classification does point up some basic distributional pattern differences in Sphagnum that may eventually be found to be physiologically based.

The presence of a great diversity of both coastal and inland mire habitats is a major factor contributing to the great diversity in Sphagnum, but also important is New York's latitudinal position that causes many northern and southern distributions to overlap. In New York, Sphagnum centrale, S. teres, S. contortum, S. platyphyllum, S. lindbergii, S. majus, S. jensenii, S. wulfianum, S. warnstorfii and S. subfulvum are all either at or within a few degrees of latitude of their southern range limits for eastern North America, while S. portoricense, S. henryense, $S$. trinitense and $S$. tenerum are close to their northern range limits.

\section{Worldwide Distribution:}

All twenty continental and widespread species have circumboreal distributions and thus oceur throughout the northern hemisphere. Of the remaining species, all but S. recurcum and S. andersonianum also occur in Europe, most of them being amphipacific as well. It is remarkable to note that $37 \mathrm{New}$ York sphagna occur in Europe while 
at least 31 species are native to Japan also. Regarding the widespread distribution patterns typical of Sphagnum in general, there are no European species that do not also occur in North America, and even in a country as northerly as Finland, 34 of 39 species also are found in New York State.

\section{New York Distribution:}

New York can be subdivided into several physiographic provinces (see Map 1), with some rather striking contrasts emerging when the numbers of Sphagnum species known from each are compared (see Table 2). Although some of these differences undoubtedly reflect collecting patterns, New York has been thoroughly enough collected throughout that these numbers are likely to reflect real differences in the diversity of Sphagnum. An examination of the physiography and geology of each province provides some insight into the factors responsible for these differences. The province descriptions that follow are based on Broughton et al. (1966), Fenneman (1938) and Miller (1913).

1. St. Lawrence-Champlain Lowlands. Low-lying with numerous low hills, the St. Lawrence-Champlain Lowlands are underlain with sandstones and limestones and often covered with glacial drift. The most important Sphagnum sites are several "flatrock" pine barrens in the northeast corner of the province where Sphagnum is often abundant over poorly drained sandstone. The low number of sphagna reflects both the lime influence and the generally limited habitat diversity.

\section{TABLE 2. OCCURRENCE OF SPHAGNUM SPECIES IN NEW YORK'S PHYSIOGRAPHIC PROVINCES}

\section{Physiographic Province}

St. Lawrence-Champlain

Lowlands

Adirondack Highlands

Tug Hill Cuesta

Ontario-Erie Lake Plain

Mohawk Valley

Allegheny Plateau

Catskill Mountains

Hudson Valley

Long Island
No. of Sphagnum spp. Known 
4. Ontario-Erie Lake Plain. The generally flat aspect of the Ontario-Erie Lake Plain is broken mainly by relatively small relief features of recent glacial origin such as drumlins and recessional moraines. The underlying rock is sedimentary and consists primarily of sandstone, siltstone, limestone and shale. In the eastern portion of the province thick glacial overburden has created numerous mire habitats. Because of the variety of underlying bedrock a full range of poor through rich fens is present, and consequently a fairly high number of sphagna are found.

5. Mohawk Valley Province. Although called a valley, considerable topographic relief is present here, due to both glacial features and underlying bedrock inequities. The bedrock is shale, sandstone and limestone with black shales predominating. Drainage is generally good and fen habitats uncommon. The number of Sphagnum species is higher than might be expected, mainly as a result of very thorough collecting in the far eastern portion of the valley.

6. Allegheny Plateau. The largest province in the State, the Allegheny Plateau is actually the northern tip of the Appalachian Plateau that extends along the western base of the Appalachian Mountains. Shale, sandstone and siltstone underlie the area, with the glacial overburden of varying thickness. A small portion of southern Allegany County was the only area in upstate New York to escape Wisconsin glaciation. Drainage is good throughout, and mire sites are mostly small and forested. A notable exception to this is the series of open fens developed in extensive morainal deposits between Ithaca and Cortland.

7. Catskill Mountains. The Catskill Mountains are basically a deeply dissected plateau, capped with a thick layer of resistant sandstone and conglomerate. Due to its porose nature, this layer resists concentration of water into streams and the infrequent mires are mostly poor, wooded fens. Reflecting the similar bedrock, the $S p h a g n u m$ list is very similar to that for the Tug Hill Cuesta, with additions coming mainly from mires near the province margin.

8. Hudson Valley. Quite highly heterogeneous, the Hudson Valley province can perhaps best be characterized as a depression between the western New England and eastern New York highlands. The western portion is primarily a shale-underlain lowland of little topographic relief, and is generally poor in mire habitats. In the northern part, however, are extensive sand plains that once bordered extinct, glacial Lake Albany, and boggy habitats are frequent there in some locations. The province's eastern portion consists of rather strongly dissected topography, and grades from the Hudson Highlands in the south to the Taconic Mountains in the north. Highly folded, resistant metamorphic rocks characterize the Hudson Highlands, and good drainage makes for few mires. The Taconic Mountains, also strongly dissected, owe their relief to resistant schists capping the mountains and nonresistant limestone in the valleys. Here again, mires are generally rare. In the middle of the Taconic area, however, and developed on a resistant graywacke, is the approximately 180-mile-square Rensselaer Plateau. It's gentle relief, high elevation (1500-2000 ft.), acidic bedrock and the often heavy glacial deposits have created numerous poor fens of both open and forested character. In the southwest corner of this province where it borders the Catskills is another strongly differentiated area-the Shawangunk Mountains. These unique, flat-topped, steepsided mountains have resulted from dissection of flat-lying beds of highly resistant conglomerate, and the poorly drained and acidic nature of their summits has created habitats for the relatively uncommon $S$. tenellum. Due to the great variety of habitats, species diversity in the Hudson Valley is second only to the Adirondack Mountains.

9. Long Island. Long Island is essentially part of the Wisconsin glaciation's terminal moraine. It's low hills are mostly gravel deposits, with the bulk of the island composed of sand, especially the unglaciated southern shores. Numerous small, freshwater streams and ponds occur which, because of the sandy substrate, contain quite acidic and weakly mineralized water. As a result, nearly every pond and stream that has remained relatively undisturbed and unpolluted contains a conspicious growth of Sphagnum. The character of the water seems to vary little, and virtually every mire is of the very poor or poor fen type. In spite of the narrow range of mire types, the number of Sphagnum species present is high; numerous coastal endemics are present as well as the usual widely distributed species.

\section{MORPHOLOGY}

Aspiring Sphagnum taxonomists quickly learn of the frustrating amount of morphological variability associated with individual species. Most of this variability is almost certainly due to phenotypic responses to environmental factors, especially moisture stress, but a genetic component is likely involved in many cases. The best approach to the problem of phenotypic variability is to attain a good sense of how key characters vary under different conditions and then use this sensitivity to interpret difficult materials. 
For example, individual species often show great variability in gross phenotype. Depending on site, the same species may be slender, compact, lax or even prostrate. The more compact forms typically occur in more xeric populations in habitats such as hummock tops, while lax, weak-stemmed forms are found in very wet, often aquatic sites. Individual species are, however, often recognizable on gross appearance, especially in characteristic habitats, and an experienced observer can identify many populations in the field on this basis. More difficult variations, however, are those involving microscopic details, upon which the keys are usually based. Phenotypic variability occurs over a wide spectrum of characters, including leaf shape, leaf size, branch leaf cross-section, stem cortical pores and numbers of branches per fascicle. Most of this variability is treated adequately under individual species discussions, but a general discussion is needed for stem leaf variability. Perhaps because they are not as intimately involved with water gain and loss as the much more numerous branch leaves, stem leaves differ more between similar species, and they are thus a valuable taxonomic aid. Unfortunately, stem leaf characters can be subject to considerable variation, especially in response to hydrologic stress. Fortunately, the most important variations occur in a predictable way so that, by knowing the kinds of changes that occur, it is often possible to recognize even strongly modified stem leaves of many species.

In all of our sphagna that have clearly differentiated stem leaves (i.e., all but S. pylaesii) an anisophyllous form exists in which the stem leaves are maximally different from branch leaves of the same species. Anisophyllous stem leaves are those which differ maximally from branch leaves and presumably are indicators of optimal habitat. Modifications away from this condition represent a stress response. Anisophyllous stem leaves can be characterized as follows:

1. Hyaline cell walls often resorbed on one or both surfaces.

2. Hyaline cells efibrillose (except in S. tenellum and S. platyphyllum).

3. Hyaline cells aporose or nearly so.

4. Hyaline cells short and broad, t rhombic.

5. Hyaline cells $1-2$ divided in many species.

6. Border (in sections Rigida, Subsecunda, Cuspidata and Acutifolia) \pm strongly broadened toward the leaf base.

7. Shape markedly different from branch leaves.

Under hydrologic stress, Sphagnum plants often develop stem leaves that differ from the anisophyllous form. The nature of these morphological modifications is such that stem leaves developed under conditions of hydrologic stress take on many characters normally associated with branch leaves. In extreme cases, this results in isophyllous stem leaves which strongly resemble branch leaves on the same plant. Isophyllous stem leaves are especially frequent when plants are growing in sites where alternate wetting and drying are common--along shorelines, over rock, etc. Their production can be seen as an adaptive mechanism, since the branch leaf morphology, with its abundant fibrils and pores, is much more suited to water retention than that of the anisophyllous stem leaves.

Much more frequently encountered, however, are the hemisophyllous forns which are the intermediate stages between anisophylly and isophylly. So many kinds of intermediate forms are possible that the best approach to understanding them is to know the kinds of modifications that occur as a given genotype alters from anisophyllous to hemiisophyllous to isophyllous. On page 10, the major morphological modifications are indicated. The exact sequence of these changes is difficult to predict as it apparently varies both with species and the kind of hydrologic stress involved. By being aware of the kinds of changes to be expected, and also by studying genotypically identical populations as they vary through environmental gradients, it is possible to understand more clearly Sphagnum stem leaf variations. In the case of "juvenile" plants, the developmental sequence is reversed, with stem leaves progressively changing from the isophyllous form on young simplex and subsimplex plants to the anisophyllous forms characteristic of fully developed mature plants. It should also be noted that in some species it is common to find a variety of stem leaf forms on the same plant if the degree of stress varies either during the year or from year to year.

In some species, stem leaf modifications are so widely prevalent in given geographic areas that they evidently are climatically induced. For example, S. rubellum in the northern portions of its range is mostly anisophyllous while plants from its southern distribution are mostly hemiisophyllous. A similar tendency is found in $S$. nemoreum and probably other species as well. Such variations have led to different key characters being applied to the same species in different geographic areas.

Many species have been described, based upon hemiisophyllous and isophyllous material, with Warnstorf being the most profligate in this regard. Among recent work, Suzuki (1956b, 1958) in his revision of the Japanese 
sphagna made special effort to account for intraspecific stem leaf variability, and was able to demonstrate a complete series of forms for many species, as follows:

Hyaline cells, if resorbed in anisophylly, develop intact walls on both surfaces.

Hyaline cells develop fibrils starting at the leaf apex and working down.

Hyaline cells develop pores, starting at the apex on the convex surface and later on the concave surface also. Hyaline cells become longer, narrower, and more S-shaped.

Anisophyllous $\rightarrow$ hemiisophyllous $\rightarrow$ isophyllous

Hyaline cell divisions become less frequent and eventually absent.

Border becomes progressively less broadened basally.

Leaf shape becomes more pointed and involute.

Particularly striking in the sphagna is their seemingly infinite variety of colors. Earlier work generally considered species to have one of two basic pigments, brown or purplish-red. Later biochemical research, however, has demonstrated basic pigments of brown, red and violet (Mårtensson and Nilsson, 1974). Apparently all species possess the red and brown pigments while those normally considered to be purplish-red also have the violet pigment. The violet pigment dominates over the brown and red while the brown usually masks the red. Thus the division of species into "brown" or "purplish-red" is functionally accurate; however, all kinds of interesting variations are possible. Under certain conditions, especially on exposed sites, many so-called "brown" sphagna such as S. tenellum, S. lescurii, S. compactum, S. uulfianum and S. palustre can develop noticeable red coloration. The brown pigment is a polymer (Bendz et al., 1965), and the greater the degree of polymerization the darker brown the color becomes; this accounts for the great range of "browns" found in various species. Sphagnum cuspidatum, for example, is usually quite light yellowish-brown in the same mixed stand with $S$. majus, which will often be much darker.

Intensity of coloration varies greatly even within individuals of a species. Rudolph (1964) has shown that, for S. magellanicum at least, the governing factor in pigment development is low temperature in the growing season. An inverse relationship exists between growth and pigment formation (Paton and Goodman, 1955; Rudolph, 1964), thus accounting for some of the seasonal variations in pigment intensity, with the deepest shades occurring in cool, fall weather. Some species (S. squarrosum, S. fimbriatum) seldom develop any noticeable color other than green where they occur in New York. But these same species frequently are quite deeply pigmented in more northerly areas, where they grow under colder, more exposed conditions. The brown pigment is apparently quite stable after the death of plants, but the red and violet pigments gradually fade (Mårtensson and Nilsson, 1974), eventually leaving old herbarium specimens with a dull, drab, brown appearance. Also quite noticeable on dried specimens of some species is a glossy metallic bluish sheen. Morris (1977) has demonstrated that in S. subnitens from Britain this sheen results from the structural optical properties of the branch leaf hyaline cells and has nothing to do with the pigments. The metallic sheen of S. subfulvum, S. flavicomans and occasionally S. warnstorfii is almost certainly of similar origin. 


\section{SPHAGNUM}

Common Names: Peat Moss, Bog Moss, Sphagnum Moss

Authority: Linnaeus, Species PI. II., p. 1106, 1753.

Description: Protonema thallose and typically one cell thick; gametophyte developing from lateral margin; plants upright (sometimes prostrate), with a strong central stem and branches in fascicles of $2-12$ (except in simplex forms); branches of two kinds, hanging (wick) and spreading; hanging branches pendent along the stem and typically softer and weaker than the spreading branches; branch fascicles spirally arranged around the stem and coming close together at the plant's apex to form the capitulum (head); leaves one cell thick, composed of a matrix of clear, dead, hyaline cells and green, living, chlorophyll cells, leaves typically dimorphic, stem leaves smaller, less fibrillose, less porose, more frequently septate and with a greater width/length ratio than the branch leaves; in some sections cell walls absent (resorbed) on one or both surfaces of the hyaline cells and with borders strongly broadened basally, these characters always lacking in branch leaves; isophyllous forms with stem and branch leaves similar; branch leaves with hyaline cells reinforced by spiral or ring-like fibrils (except in S. macrophyllum) and bearing few to numerous (rarely no) pores, pseudopores and/or wall-thinnings; stems typically consisting of three distinct layers: 1) a central cylinder of thin-walled, colorless, parenchymatous cells that merges outward into 2) several layers of thick-walled, pigmented, prosenchymatous cells of the wood cylinder which are in turn usually surrounded by 3) a cortex of one or more layers of thin-walled, clear, parenchymatous cortical cells (cortex sometimes indistinct or lacking); plants monoicous or dioicous; antheridia long-stalked and globose to oval, developed singly in the leaf axils on antheridial branches, these similar to but more deeply pigmented and compact than nonantheridial spreading branches; archegonial branches short, green and bud-like; bearing 1-5 long-stalked archegonia enclosed in large strongly differentiated perichaetial leaves; mature capsules one per archegonial branch, globose, dark brown to black, with operculum but lacking peristome or annulus, borne on a pseudopodium, a stalk-like outgrowth of the gametophyte; spores tetrahedral, when mature $28-45 \mu$ in diameter; basic pigments green, brown, red and violet; the plants themselves variously colored depending on the pigments present in a given species and environmental factors affecting their expression. Plants perennial and growing upright, prostrate or floating in \pm dense stands on wet acidic to weakly basic sites with \pm weakly mineralized water supplies.

\section{KEY TO SECTIONS OF SPHAGNUM}

1. Cortical cells of stem (Fig. 1) with reinforcing fibrils; branch leaves strongly cucullate (Fig. 2) .........

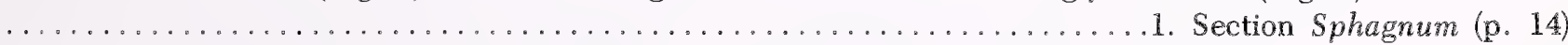

1. Cortical cells of stem without reinforcing fibrils; branch leaves not strongly cucullate ..............(2)

2. Branch cortical cells of one kind, mostly with pores (Fig. 3); branch leaves denticulate margined (Fig. 4) 2. Section Rigida (p.23)

2. Branch cortical cells of two kinds--porose, retort cells and smaller aporose cells (Fig. 5); branch leaves not

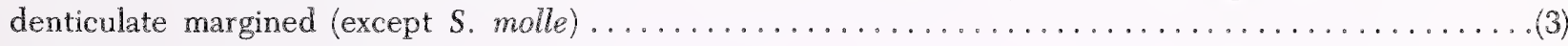

3. Branches 6 or more per fascicle .......................... Section Polyclada (p. 58)

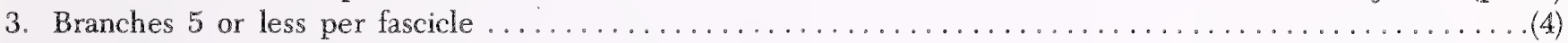

4. Branch leaf hyaline cells efibrillose (Fig. 6) ................. Section Isocladus (p. 37)

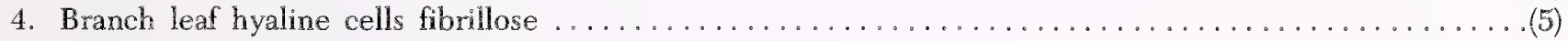

5. Stem leaves isophyllous, normally larger than branch leaves; plants sparingly branched or unbranched, often procumbent; leaves oval to ovate ..................... Section Subsecunda (in part) (p. )

5. Stem leaves not normally isophyllous; plants normally branched and erect or aquatic; leaves variously shaped

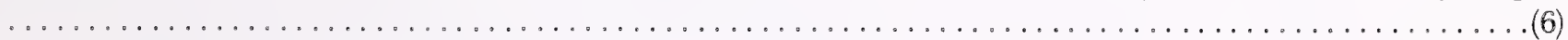
6. Branch leaf chlorophyll cells in transverse section triangular to trapezoidal, exposed more broadly on concave surface (Fig. 7 ); plants often purplish-red ................. Section Acutifolia (p. 59)

6. Branch leaf chlorophyll cells in transverse section exposed more broadly on the convex surface or equally on both surfaces; plants never purplish-red

7. Stem leaves lingulate, apex broad, rounded and fimbriate (Fig. 8); branch leaves with large and numerous rounded pores on the concave (Fig. 9) and convex (Fig. 10) surfaces; hyaline branch leaf cells often finely papillose where overlying chlorophyl cells; branch leaves often squarrose......3. Section Squarrosa (p. 26)

7. Stem leaves triangular to lingulate, apex mucronate, acute, obtuse, or rarely broad, rounded and erose to fimbriate; branch leaf pores various but never both large and numerous on both surfaces; hyaline branch leaf cells epapillose where overlying chlorophyll cells; branch leaves only very rarely squarrose (as in $S$. lescurii) 

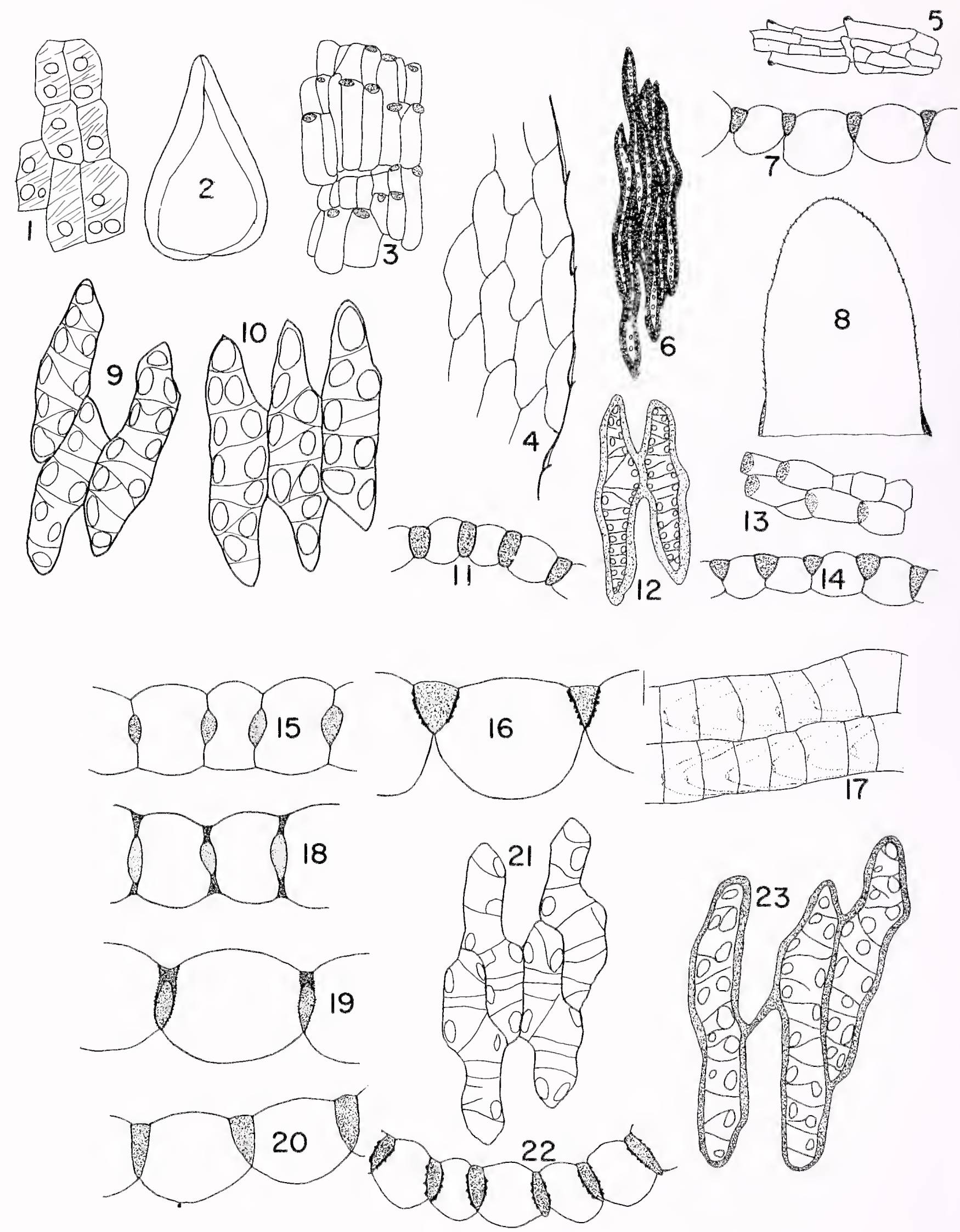
8. Branch leaf chlorophyll cells in transverse section truncate-elliptic to trapezoidal, exposed equally on both surfaces or slightly broader on the convex surface; (Fig. 11); branch leaf hyaline cells (except in some aquatic modifications) with numerous small round pores and/or pseudopores along the commissures (Fig.

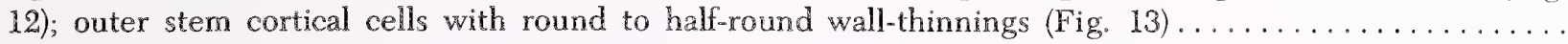
$\ldots \ldots \ldots \ldots \ldots \ldots \ldots \ldots \ldots \ldots \ldots \ldots \ldots \ldots \ldots \ldots \ldots \ldots \ldots \ldots$ Section Subsecunda (in part) (p. 29)

8. Branch leaf chlorophyll cells in transverse section triangular to trapezoidal, exposed more broadly on the convex surface (Fig. 14); branch leaf hyaline cells lacking numerous small round pores along the commissures (if pores small and round, these free and not along the commissures, see S. majus and S. jensenii); outer stem cortical layer without pores or wall-thinnings ...........6. Section Cuspidata (p. 39)

\section{MULTIPLE-ACCESS KEY TO SECTIONS OF GENUS SPHAGNUM}

Due to difficulty often encountered in using dichotomous keys to Sphagnum, wherever appropriate the alternative approach of a multiple-access key will be offered. Multiple-access keys can be used in several ways. The first is to write out all the numbers referring to the taxonomic units being keyed out. For the following key, the numbers 1 through 8 are written out. Then, choosing any character in the key, check for character state and cross out any numbers not listed after that character state. Proceed through additional characters in any order until only one number is left. This number indicates the section you have just keyed out. An altemative, quicker method using punch analysis cards is described in Vitt and Andrus (1977).

\section{Character}

Fibrils of stem cortex

Porosity of stem cortex

Stem leaf apex

Stem leaf shape

Stem leaf border

Number of branches/fascicle

Branch leaf apex

Branch leaf border

Branch leaf hyaline cell fibrillosity

Branch leaf convex surface pores

\section{Character State}

\section{STEM CORTEX}

1. with reinforcing fibril bands: 1

2. without reinforcing fibril bands: all others

3. with clear pores: 1,8

4. with wall-thinnings: $3,4,8$

5. without pores or wall-thinnings: $2,3,4,5,6,7,8$

\section{STEM LEAVES}

6. pointed: $4,6,8$

7. rounded: all

8. spatulate: $1,6,8$

9. lingulate: $1,3,4,6,8$

10. triangular to lingulate triangular: $2,4,5,6,7,8$

11. ovate: 4,6

12. borderless at apex and sides: $1,3,6,8$

13. borderless across at least $1 / 2$ broad rounded apex: $2,4,5,6,7,8$

14. bordered except at extreme apex: $4,5,6,8$

\section{BRANCHES}

15. 6 or more: 7

16. $0-2: 4$

17. $3-5: 1,2,3,4,5,6,8$

\section{BRANCH LEAVES}

18. hooded: $1,2,8$

19. involute: $2,3,4,5,6,7,8$

20. toothed: $1,2,6,8$

21. entire: $3,4,5,6,7,8$

22. efibrillose: 5

23. fibrillose: all others

24 . $\leq 12 /$ cell: $1,4,5,6$

25. > 12/cell: $1,2,3,4,6,7,8$ 
Position of branch leaf convex surface pores

Branch leaf chlorophyll cell exposure
26. free from commissures: 5, 6

27. along commissures: $1,2,3,4,6,7,8$

28. enclosed within both surfaces: 1,2

29. exposed \pm equally on both surfaces: $1,3,4,5,7$

30. clearly exposed more greatly on convex surface: $2,4,6$

31. clearly exposed more greatly on concave surface: $1,4,8$

\section{SECTION LIST}

1. Sphagnum; 2. Rigida; 3. Squarrosa; 4. Subsecunda; 5. Isocladus; 6. Cuspidata; 7. Polyclada; 8. Acutifolia

\section{SECTION SPHAGNUM}

Description: Stem cortex 3-4 layers of greatly enlarged, thin-walled cells reinforced by spiral fibrils and with 1-10 round pores per cell; stem leaves spatulate-lingulate and borderless, the convex surface with extensive cell wall resorption, apex fimbriate and sides denticulate, hyaline cells short, broad, and irregularly rhomboidal; branch cortex of uniform, nonretort-shaped cells with reinforcing fibrils and typically 1 pore per cell; branch leaves oval to broadly ovate, concave, the apex cucullate with cell wall resorption on the convex surface and the margin borderless and denticulate; hyaline cells of the branch leaves having small- to medium-sized, round to elliptic, few to numerous pores in the cell angles and along the commissures on their convex surface and with large round pores free from the commissures in the lower side regions or throughout on the concave surface; chlorophyll cells of the branch leaves in transverse section varying from short-elliptic to equilateral-triangular in shape, completely enclosed, equally exposed or more broadly exposed on the concave surface; branch leaf hyaline cell walls where overlying chlorophyll cells smooth or with papillae, ridges or comb-fibrils; pigment brown, reddish-brown or purplish-red.

Note: Species of section Sphagnum are distinguishable from species of other sections by their robust appearance broad cucullate branch leaves, large unbordered stem leaves and thick loose stem cortex. Section Sphagnum has also been referred to various subgeneric levels as the Inophloea, Cymbifolia and Palustria.

\section{KEY TO SPECIES OF SECTION SPHAGNUM}

1. Branch leaf chlorophyll cells completely enclosed on both surfaces (Fig. 15); plants purplish-red when

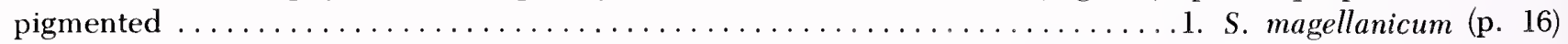

1. Branch leaf chlorophyll cells exposed on one or both surfaces; plants reddish-brown to brown when pigmented

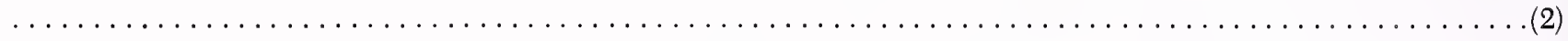

2. Branch leaf chlorophyll cells \pm equilateral-triangular (Fig. 16) with the base on the concave surface; combfibrils often present on the hyaline cell walls where overlying chlorophyll cells ...............(3)

2. Branch leaf chlorophyll cells isosceles-triangular, trapezoidal, truncate-elliptic or lenticular; comb-fibrils

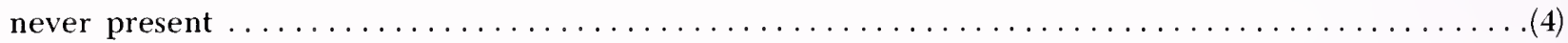

3. Branch cortical cells each projecting into the next with a funnel-shaped end wall (Fig. 17); branches tightly imbricate and club-shaped. (An oceanically distributed species of the Atlantic coast, very rare north of New

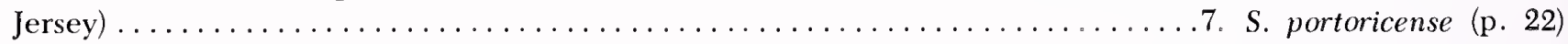

3. Branch cortical cells with flat end walls; branches normally lax and not club-shaped. (Wide-spread in eastern

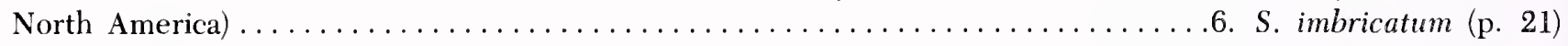

4. Branch leaf chlorophyll cells in transverse section lenticular to narrowly elliptical (Fig. 18)..........

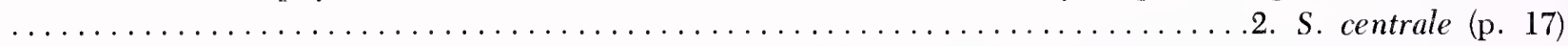

4. Branch leaf chlorophyll cells in transverse section isosceles triangular, trapezoidal or truncate-elliptic. .(5)

5. Branch leaf chlorophyll cells smooth or with irregular worm-like ridges where overlying chlorophyll cells; stem

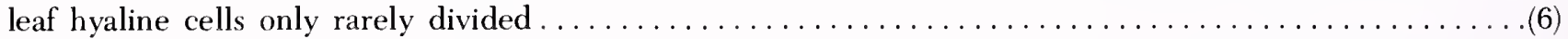

5. Branch leaf chlorophyll cells papillose where overlying chlorophyll cells (Fig. 19); stem leaf hyaline cells frequently divided $\ldots \ldots \ldots \ldots \ldots \ldots \ldots \ldots \ldots \ldots \ldots \ldots \ldots \ldots \ldots \ldots \ldots \ldots \ldots \ldots$. . . papillosum (p. 20)

6. Branch leaf hyaline cells smooth throughout (Fig. 20); pores on the convex surface (Fig. 21) elliptic to

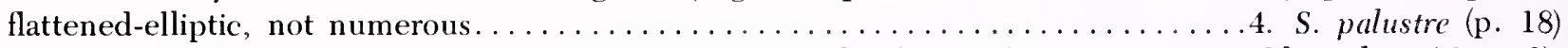

6. Branch leaf hyaline cells where overlying chlorophyll cells often with irregular worm-like ridges (Fig. 22), especially at the leaf base; pores on the convex surface numerous, small and round to elliptic (Fig. 23) 


\section{MULTIPLE-ACCESS KEY TO SPECIES OF SECTION SPHAGNUM}

\section{Character}

\section{Character State}

\section{STEM LEAVES}

Stem leaf hyaline cells

Branch leaf habit

Branch leaf convex surface pores

Branch leaf chlorophyll cell shape

Branch leaf chlorophyll cell exposure

Branch leaf hyaline cell surface where overlying chlorophyll cells

Branch cortical cells
Color

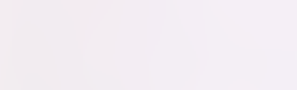

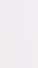

Branch cortical cells
1. often divided: $3,6,7$

2. rarely divided: $1,2,4,5$

\section{BRANCH LEAVES}

3. squarrose: 4,6

4. not squarrose: all others

5. > 10/cell: $2,5,6,7$

6. $\leq 10 /$ cell: $1,2,3,4,5$

7. equilateral-triangular: 6,7

8. isosceles-triangular: 4,5

9. trapezoidal: $3,4,5$

10. elliptical to lenticular: $1,2,3$

11. enclosed with both surfaces: 1

12. enclosed on convex surface only: $4,5,6,7$

13. exposed on both surfaces: $2,3,4,5$

14. papillose: 3

15. with comb-fibrils: 6,7

16. with irregular worm-like ridges: 5

17. smooth: 1, 2, 4, 5, 6

\section{BRANCH CORTEX}
18. projected into proximal cells with funnel-shaped end wall: 7

19. flat end walls: all others

\section{COLOR}

20. red-violet: 1

21. brown: $2,3,4,5,6,7$

22. green: all

\section{SPECIES LIST}

1. S. magellanicum;2. S. centrale; 3. S. papillosum; 4. S. palustre; 5. S. henryense; 6. S. imbricatum; 7. S. portoricense 


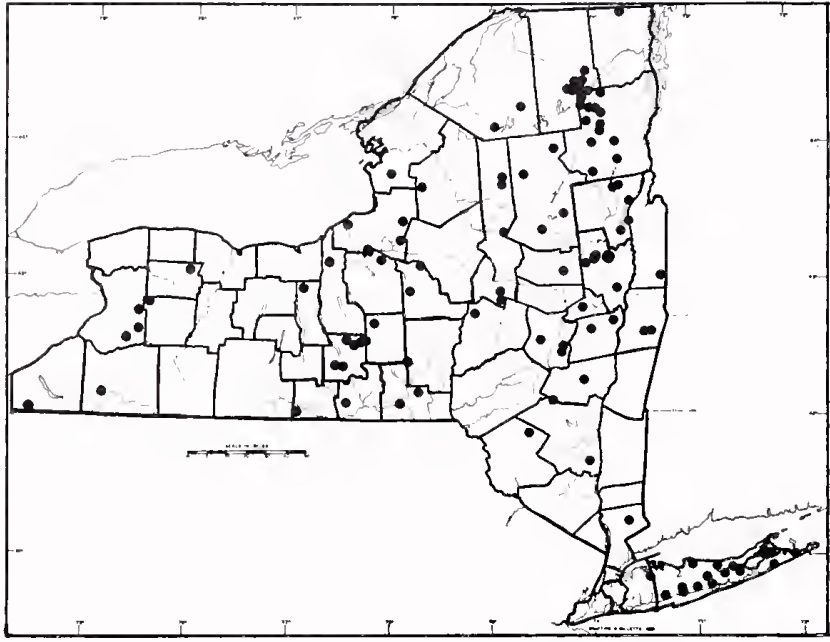

1. Sphagnum magellanicum Brid.

Type Description: Bridel-Brideri, Muscologia recentiorum 11, p. 24, 1978.

Synonym: S.' medium Limpr.

Ecology: Ombrotrophic to weakly minerotrophic. Found in a wide range of poor fen mires and occasionally even medium fens.

Habit: A moderate-sized to robust plant with a lax to compact growth form. Forms \pm dense stands on hummock sides and tops but also common in floating mats and in forested mire carpets.

General Distribution: Bipolar. Circumpolar in the Northern Hemisphere. Probably the most widespread Sphagnum. In North America from the arctic south to Florida, Texas, Idaho and California.

Description: Stem leaves with hyaline cells undivided, rarely hemiisophyllous; branch leaves imbricate to moderately lax but not squarrose in shade forms, with elliptic pores along the commissures of the convex surface; chlorophyll cells in transverse section shortelliptic and well enclosed on both surfaces and hyaline cell walls smooth where overlying chlorophyll cells; pigmentation purplish-red; plants green, pink-tinged or deep purplish-red.

Distinguishing Characters: The only species in section Sphagnum with purplish-red pigment. Other species in this section may, however, become reddish-brown or develop a faint purplish luster upon drying so some caution must be employed in utilizing pigmentation for identification. Weakly pigmented or green specimens can be distinguished by means of the branch leaf chlorophyll cells completely enclosed on both surfaces. The chlorophyll cells of $S$. centrale appear somewhat similar but their thickened end walls reach both surfaces.

Importance: Widespread and common, but not abundant enough to be a significant peat former in New York or elsewhere.
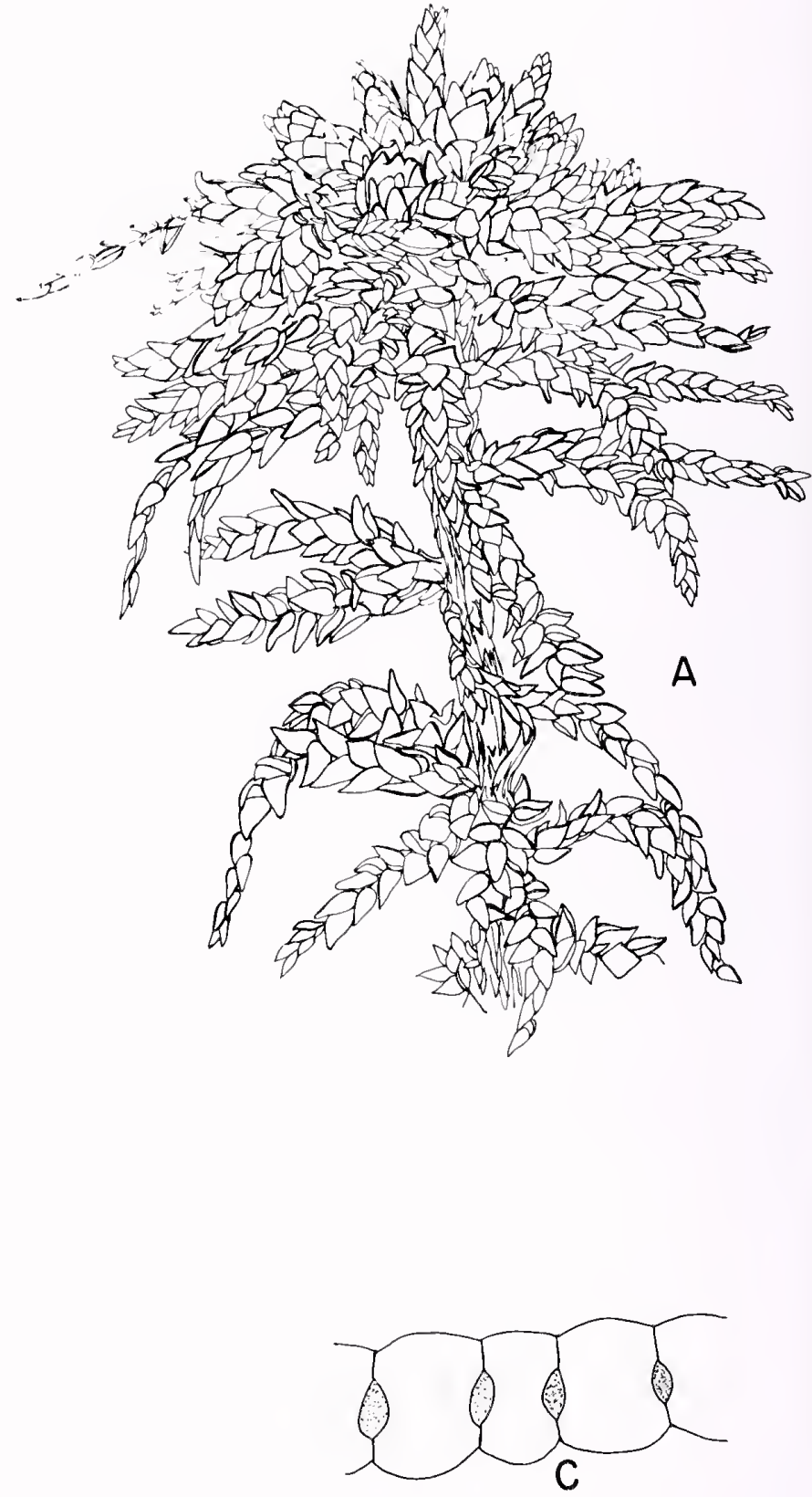


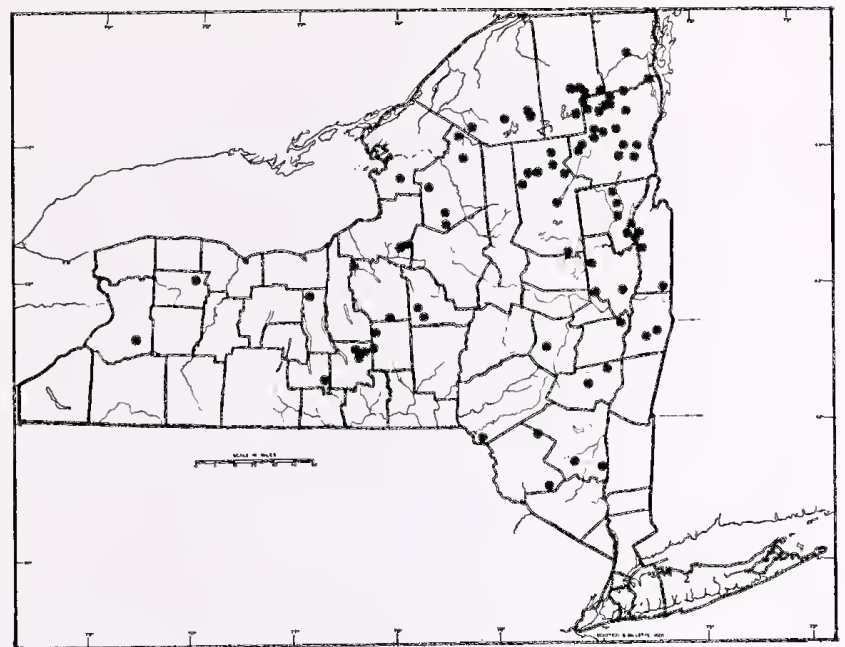

2. Sphagnum centrale C. Jens.

Type Description: C. Jensen in Arnell and Jensen, K. Svenska Vetensk-Akad. Handl. afd. III, p. 34, 1896.

Ecology: Minerotrophic, widespread in coniferous wooded fens where it is associated with Sphagnum russowii, S. girgensohnii, S. wulfianum, and S. magellanicum. In northern New York and northward also common in a wide variety of poor to rich fens as well as at pond margins. Typical associates here include S. fimbriatum, S. teres, S. subsecundum and S. lescurii.

Habit: A moderate-sized to robust plant. Generally a hummock former, but may also form \pm dense carpets, especially in forested mires.

General Distribution: Circumpolar, with continental tendencies. Distribution in North America unclear due to confounding with $S$. palustre and S. magellanicum, but at least from the arctic south to Pennsylvania, Indiana, Illinois, Iowa, Montana and Washington.

Description: Stem leaves with hyaline cells rarely divided, seldom hemiisophyllous; branch leaves imbricate to slightly lax, very rarely squarrose, with numerous elliptic (rarely round) pores along the commissures of the convex surface, these frequently becoming confluent near the leaf apex and then appearing as irregular holes at the upper end of the hyaline cells; chlorophyll cells in transverse section lenticular to narrowly elliptical, with thickened walls at both ends, often slightly more exposed on the concave surface and hyaline cell walls smooth where overlying chlorophyll cells; pigmentation brown; plants green, golden-brown or purplish-brown.

Distinguishing Characters: See under S. magellanicum, S. palustre and S. papillosum.

Importance: Of local importance as an acidifier of minerotrophic habitats. Probably never abundant enough to be a significant peat former.
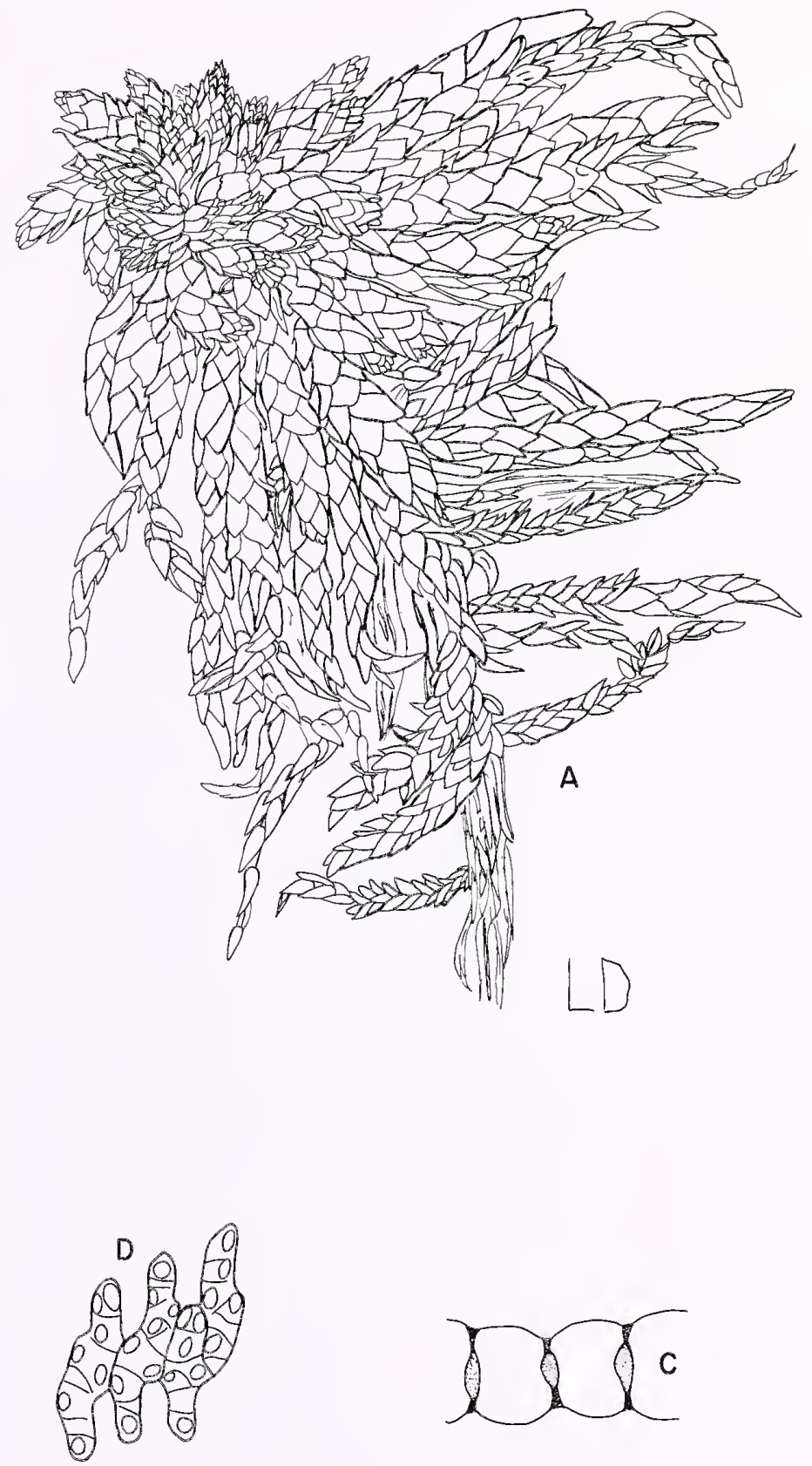


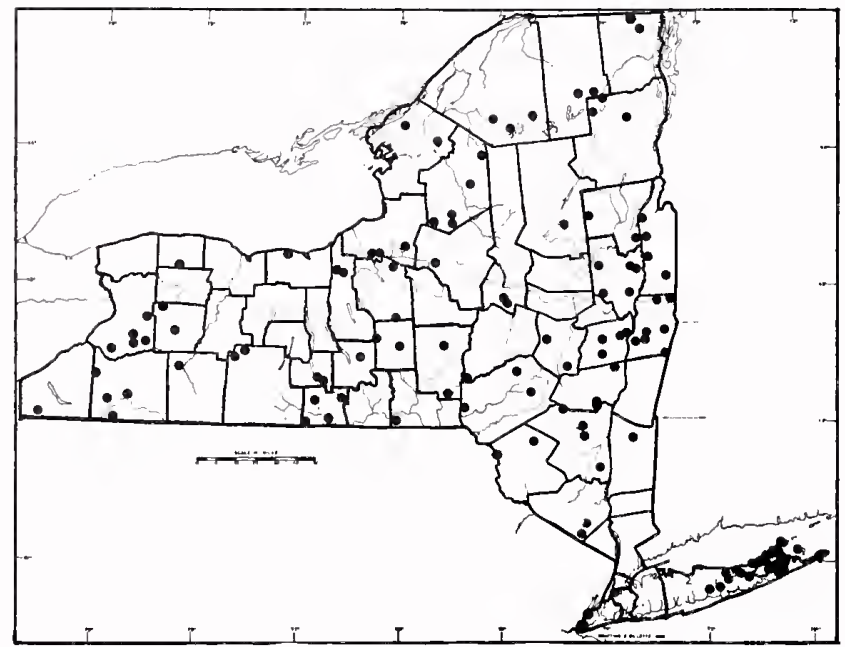

3. Sphagnum palustre L.

Type Description: Linnaeus, Species Pl., II, p. 1106, 1753.

Synonyms: S. cymbifolium Hedw., S. subbicolor Hampe.

Ecology: Minerotrophic. At margins of ponds, bogs and in a wide range of minerotrophic mires. Widely distributed, but seldom abundant where found.

Habit: A moderate-sized to robust plant with a lax to occasionally compact growth habit, it generally forms low to moderately high hummocks or may also form carpets in Salix or Alnus carrs.

General Distribution: Amphiatlantic and amphipacific, absent from much of continental interior. In North America, distributional details are unclear due to confounding with $S$. centrale and $S$. henryense, but S. palustre appears to extend southward to Florida and Texas, up the Mississippi River to Arkansas, inland around the Great Lakes to Michigan and Minnesota and on the Pacific coast from Alaska to California. Absent from arctic and subarctic regions.

Description: Stem leaves with hyaline cells only rarely divided, often hemiisophyllous; branch leaves imbricate to spreading, frequently squarrose in shade forms, with narrowly elliptic pores along the commissures of the convex surface, these becoming confluent toward the leaf apex and appearing as large irregular holes at the upper end of the hyaline cells; chlorophyll cells in transverse section isosceles-triangular to ovatetriangular with the base on the concave surface and the apex enclosed or just reaching the convex surface and hyaline cell walls smooth where overlying chlorophyll cells; pigmentation brown; plants green to golden-brown.

Distinguishing Characters: Sphagnum centrale has branch leaf chlorophyll cells that, in transverse section, are broader in the middle and narrowed toward

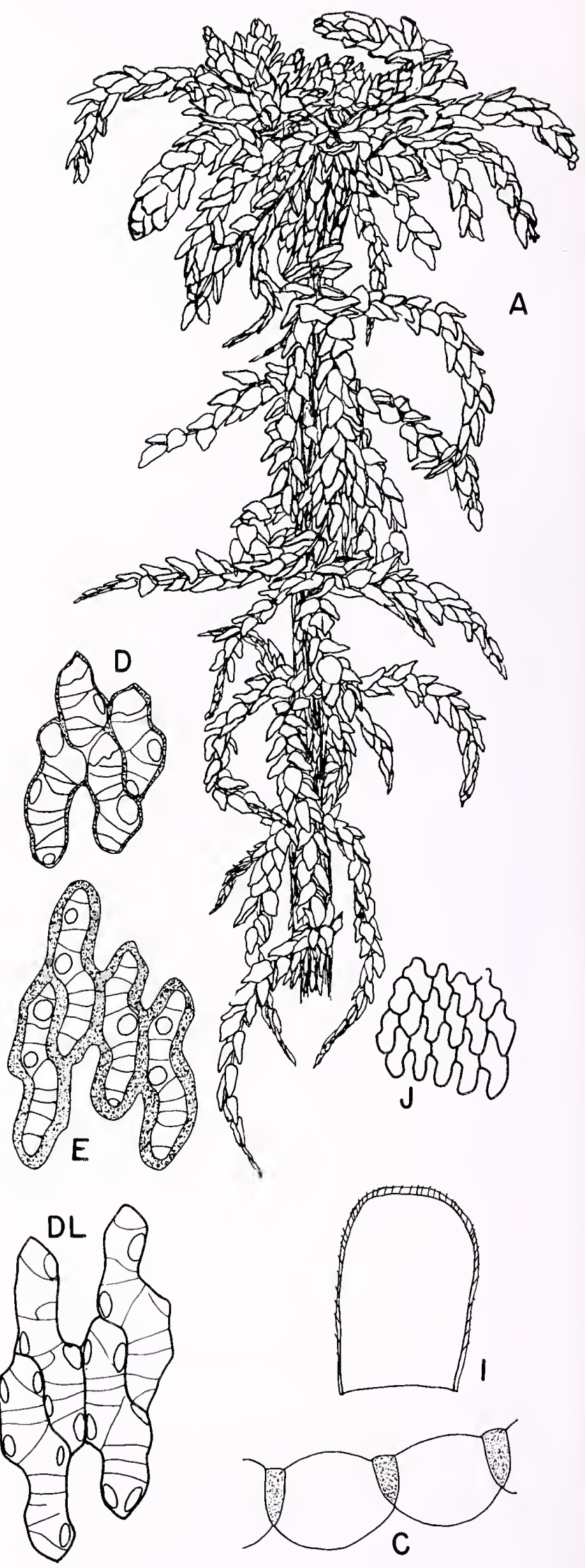


both surfaces while in $S$. palustre the cells are broadest at or very near the concave surface. Also, in transverse section, the chlorophyll cell walls of $S$. centrale are strongly thickened at both ends while those of $S$. palustre are normally uniformly thin. For distinction from S. papillosum, S. imbricatum and S. henryense, see under those species.

Infraspecific Variation: Shade forms often develop squarrose branch leaves and may then appear superficially similar to Sphagnum squarrosum.

Importance: In New York, this species is quite widespread, but never very abundant where found. Field

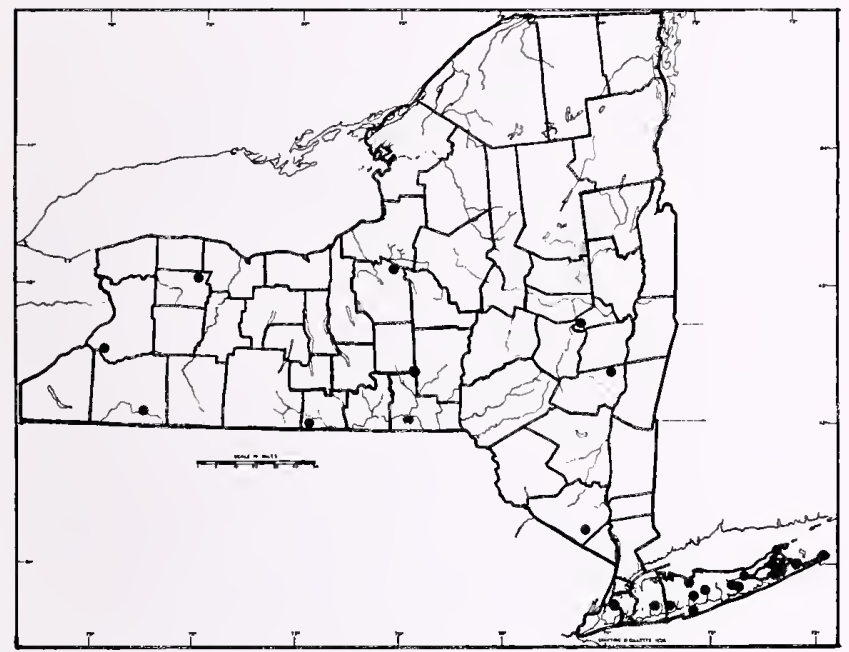

4. Sphagnum henryense Warnst.

Type Description: Warnstorf, Hedwigia, 39: 107, 1900.

Ecology: Minerotrophic. Found in poor fens, pond margins and medium to rich wooded fens. Found in habitats similar to Sphagnum palustre though usually more abundant where found than that species.

Habit: A moderate-sized to robust plant with a lax to occasionally compact growth form.

General Distribution: On the coastal plain from Massachusetts south to Florida and Louisiana and inland to Arkansas, Missouri, West Virginia and around the Great Lakes to Michigan. In western North America near the coast from Alaska to California. Japan.

Description: Stem leaves with hyaline cells only rarely divided, often \pm hemiisophyllous; branch leaves imbricate to spreading, rarely if ever squarrose, with numerous small, round to short-elliptic pores along the commissures of the convex surface; chlorophyll cells in transverse section isosceles-triangular with the base on the concave surface and the apex just reaching the convex surface; hyaline cell walls often with a network of irregular worm-like ridges where they overlie the chlorophyll cells, especially near the leaf base; experience indicates this is likely to be true throughout the rest of North America.

Note: Sphagnum perichaetiale Hampe $(=S$. erythrocalyx Hampe) is an Atlantic coastal plain species of section Sphagnum that is known as far north as New Jersey and may yet be found on Long Island. It differs from $S$. palustre in its more compact growth form, truncate-elliptic branch leaf chlorophyll cells (transverse section) and its small round pores or pseudopores on the branch leaf convex surfaces.

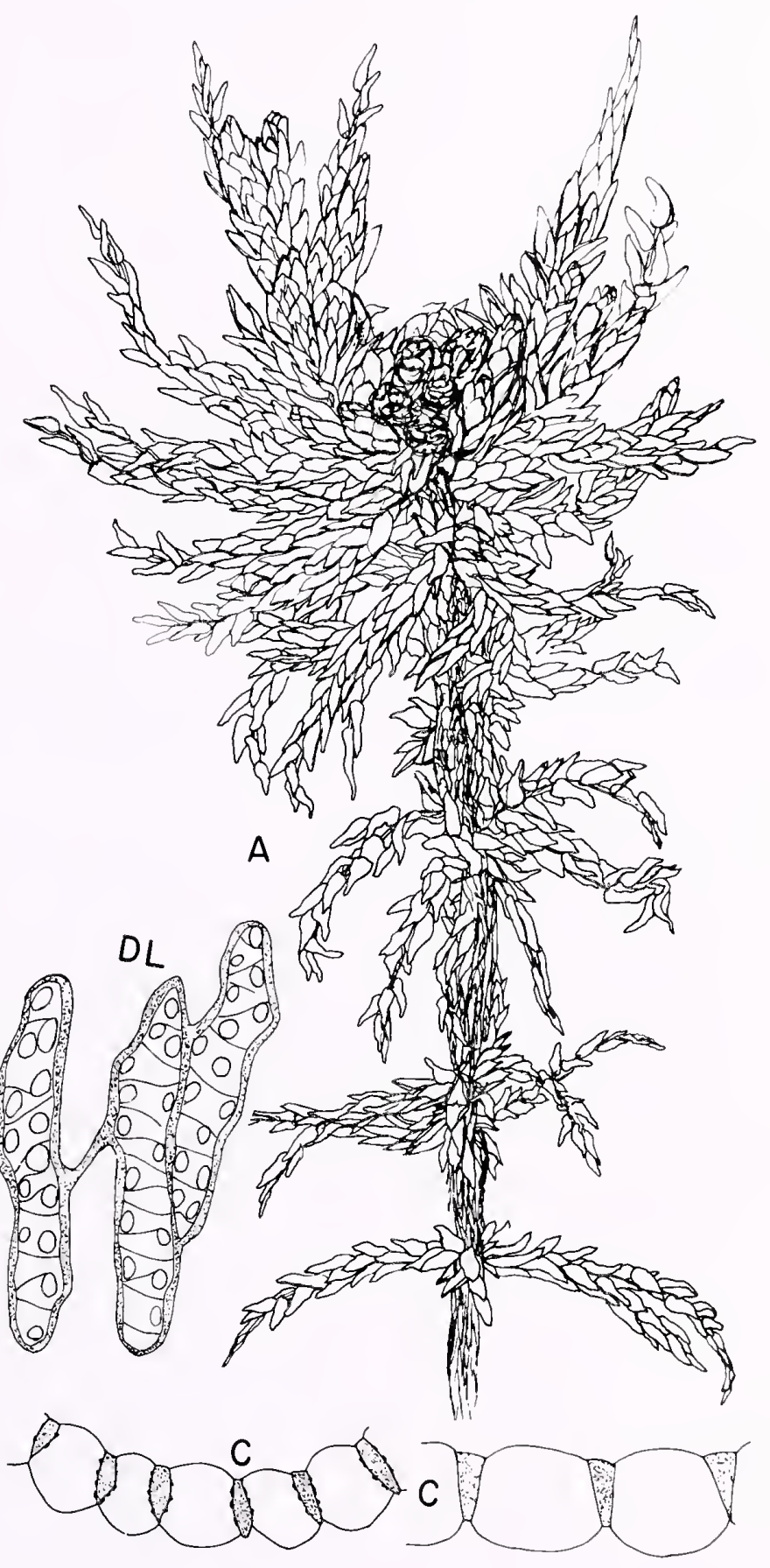


pigmentation brown; plants green or tinged brown to reddish-brown.

Distinguishing Characters: The ridge network on the branch leaf hyaline cell walls is diagnostic when present, but, unfortunately, is often obscure or perhaps even absent. In such cases, other characters must be utilized. The isosceles-triangular branch leaf chlorophyll cells in transverse section will separate $S$. henryense from all section Sphagnum species except S. palustre and S. papillosum. New York material of $S$. papillosum apparently always has discernible papillae, and its stem leaves have many hyaline cells divided. Sphagnum palustre is best separated from nonridged $S$. henryense by the pore characteristics of

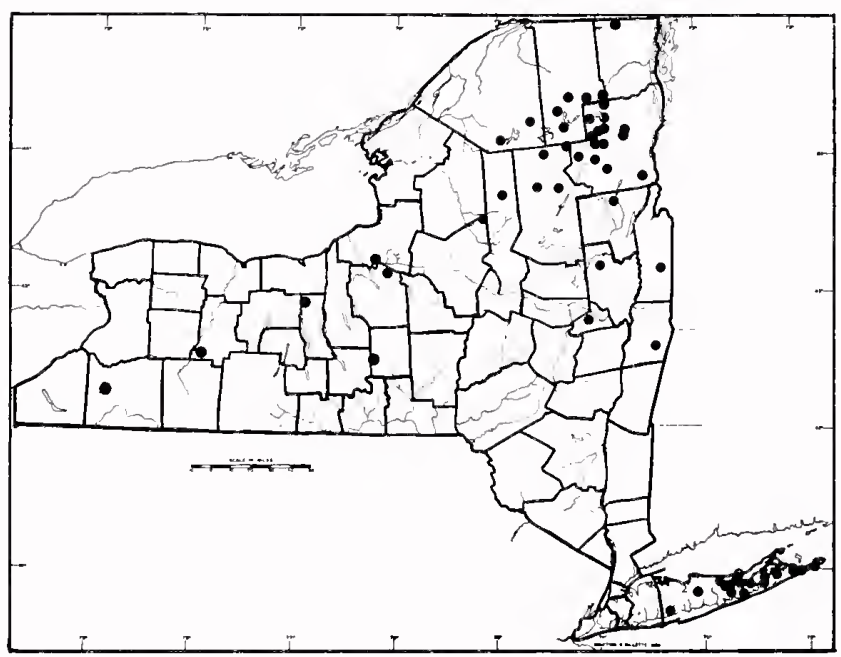

5. Sphagnum papillosum Lindb.

Type Description: Lindberg: Acta Soc. Sci. Fenn., 10: $280,187$.

Ecology: Weakly minerotrophic. A characteristic poor fen species common in wet carpets associated with Sphagnum rubellum, S. fallax, S. angustifolium, S. pulchrum, S. fuscum and S. magellanicum. In high mountain regions of New York it is common over exposed wet rock with S. pylaesii, S. fallax and S. magellanicum. A light-demanding species rarely found in forested mires.

Habit: A moderate-sized to robust plant, normally with a compact growth habit, it forms carpets or low hummocks.

General Distribution: Amphiatlantic and amphipacific. In eastern North America from Manitoba (Goose Bay) to the Hudson Bay lowlands and Labrador south to North Carolina and inland around the Great Lakes to Michigan, Minnesota and Wisconsin. On the Pacific coast from Alaska to Washington.

Description: Stem leaves and hyaline cells frequently 1-divided (sometimes in lower side regions only), occa- the convex branch leaf surface. In $S$. henryense, these pores are typically quite small, round and numerous while S. palustre has larger, less numerous, elliptical pores that become confluent apically to form large membrane gaps. Sphagnum henryense may also be recognized in the field by a soft reddish-brown color and distinctive flattened capitulum. In characteristic form, this capitulum has an aspect similar to $S$. riparium with a small but noticeable terminal bud and the newest developing branches much shorter than those immediately below.

Importance: Locally abundant, but not a significant peat former.

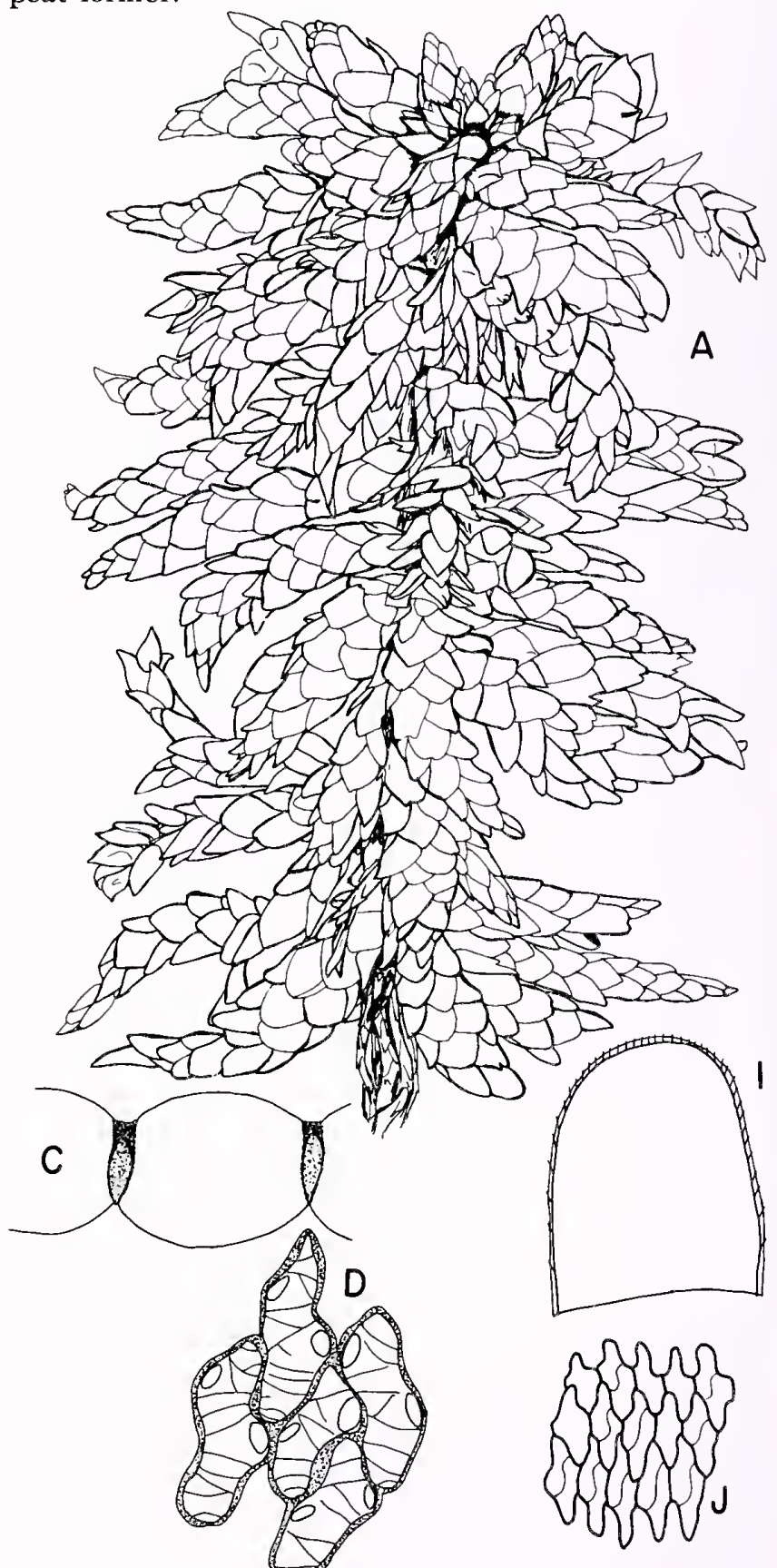


sionally hemiisophyllous; branch leaves loosely imbricate, never squarrose, with elliptic pores along the commissures of the convex surface, these becoming confluent near the leaf apex and then appearing as irregular holes at the upper end of the hyalline cells; chlorophyll cells in transverse section trapezoidal to truncate-elliptic, thick-walled (thin-walled in aquatic forms), normally more broadly exposed on the concave surface and hyaline cell walls where overlying chlorophyll cells with numerous papillae (these occasionally sparse or possibly absent); pigmentation brown; plants golden brown to dark purplish-brown, rarely green.

Distinguishing Characters: When papillae are abundant, as is the normal case, S. papillosum is easily recognized. Occasional forms, however, have the papillae faint (no epapillose forms have been seen from New York). Such forms can be determined by examination

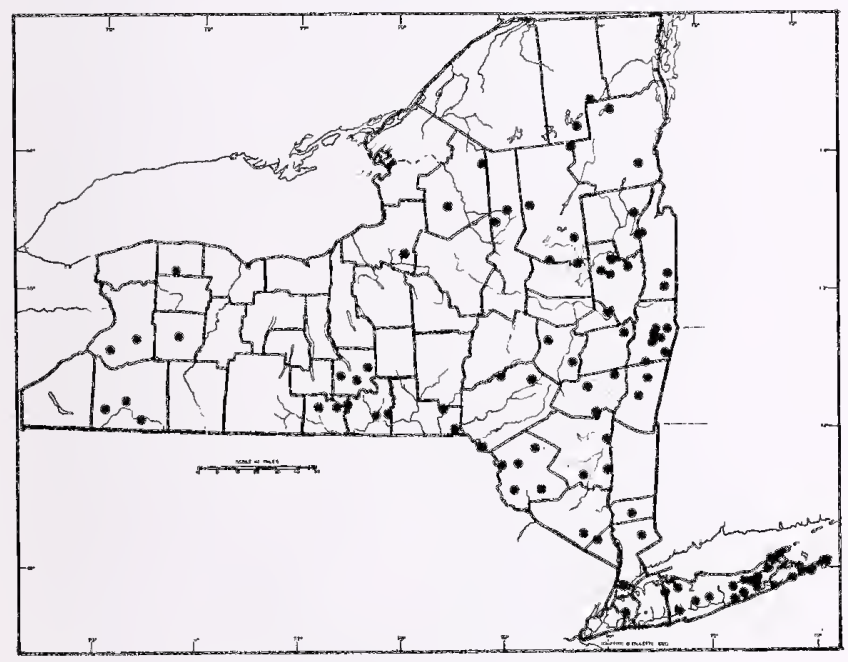

\section{Sphagnum imbricatum Russow}

Type Description: Hornschuch ex Russow, Beitr. Torfm., 21, 1865.

Synonyms: S. austinii Sull., S. affine Ren. \& Card., S. imbricatum var. affine (Ren. \& Card.) Warnst.

Ecology: Minerotrophic. Inland occurring primarily in sedge fens, Salix-Alnus carrs and occasionally pond margins. Near the coast found in a variety of poor fen habitats. Commonly associated with Sphagnum fimbriatum, S. lescurii, S. henryense and S. papillosum.

Habit: Plants are moderate to large-sized, lax or rarely moderately compact, forming mats and low hummacks.

General Distribution: Amphiatlantic and amphipacific, absent from the continental interior. In eastern North America from Newfoundland south to Florida and Texas and inland to Tennessee, Arkansas, In- of the stem leaves. This species has stem leaf hyaline cells that are often l-divided while in S. centrale and S. palustre these cells are only rarely divided. Epapillose S. papillosum, if it exists in the area of range overlap, could also be confused with $S$. perichaetiale. The latter species should be separable by its different growth habit, ecology and distinctive small round pores and pseudopores of the convex branch leaf surface. Sphagnum papillosum may often be field identified by its short, thick and blunt spreading branches. Sphagnum perichaetiale typically has short but pointed branches.

Importance: A dominant species and major peatformer in acid boreal mires with oceanic climatic influence.

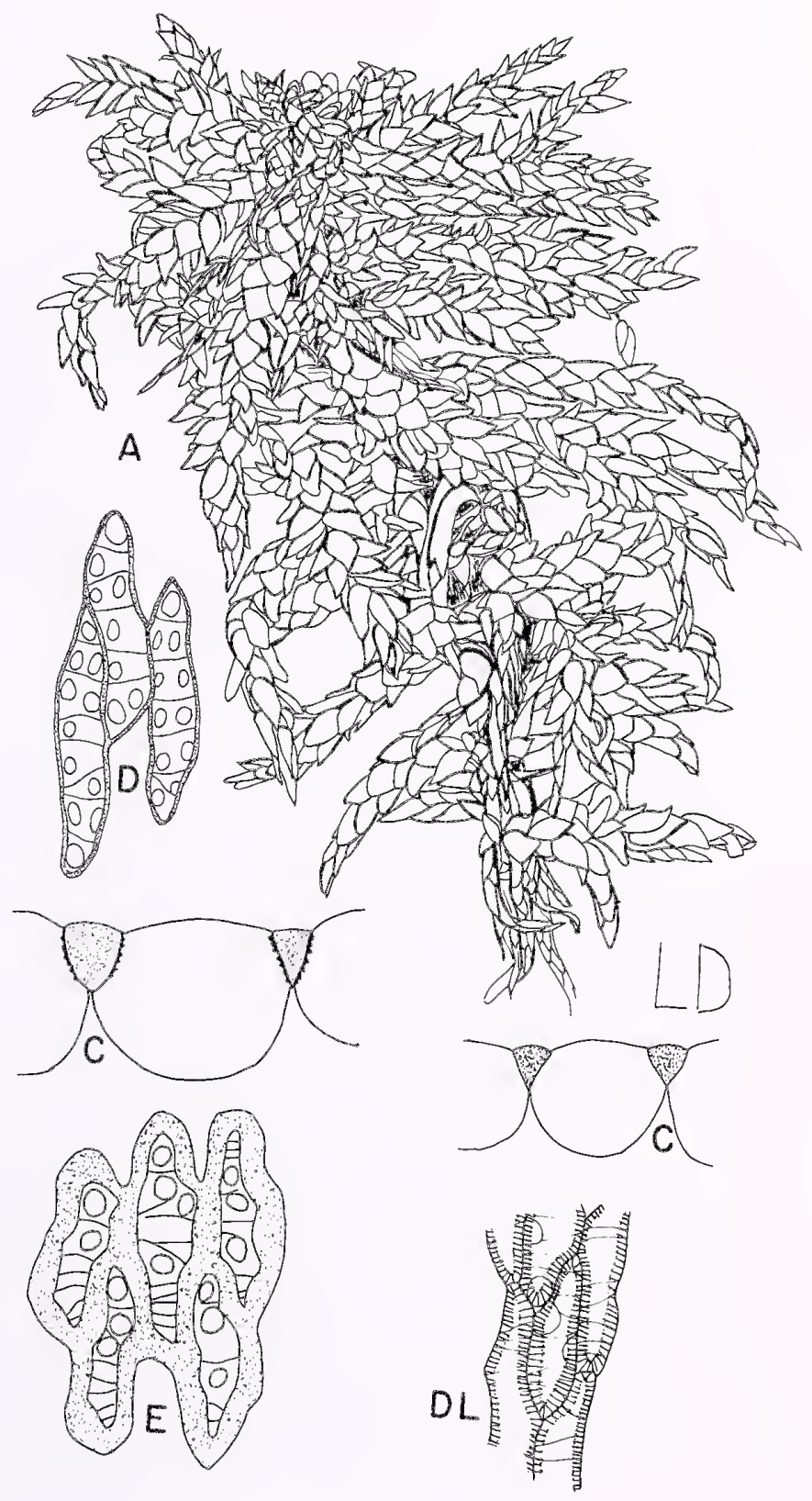


diana, Kentucky, Tennessee, and Oklahoma. On the Pacific coast from Alaska south to B.C.; also in Chile in South America (Maass, 1966).

Description: Stem leaves with hyaline cells occasionally divided, seldom hemiisophyllous; branch leaves loosely imbricate to spreading, often squarrose in shade forms, with numerous small round to elliptic pores along the commissures (sometimes also free) on the convex surface; chlorophyll cells in transverse section equilateral-triangular with the base on the concave surface and the apex typically well enclosed on the convex surface; hyaline cell walls where overlying chlorophyll cells smooth or with conspicuous combfibrils, these more frequent at the leaf base; pigmentation brown; plants green or tinged with brown to purplish-brown.

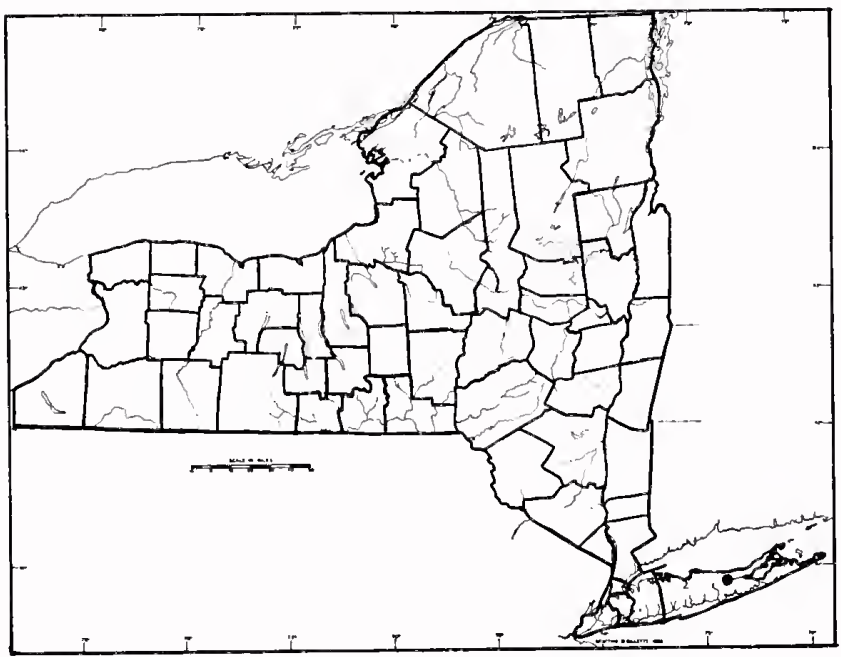

7. Sphagnum portoricense Hampe.

Type Description: Hampe, Linnaea, 25: 359, 1853.

Synonym: S. sullivantianum Aust.

Ecology: Weakly minerotrophic. The most aquatic species of section Sphagnum. In New York and New Jersey found submerged or emergent in acid, shallow, sandy-bottomed ponds associated with Sphagnum lescurii, S. pylaesii, S. cyclophyllum, S. cuspidatum, S. torreyanum and S. macrophyllum.

Habit: Moderate-sized to usually robust. Growth form lax to somewhat compact.

General Distribution: Western hemisphere. Near the coast, from Maine south to Florida and Louisiana, also in Mexico, Guadelupe, Puerto Rico and Venezuela (Maass, 1966).

Description: Stem leaves with hyaline cells often divided, frequently hemiisophyllous: branch cortical cells aporose on the outside wall, each cell extended by a funnel-like projection into the next distal cortical cell; branch leaves tightly imbricate, with numerous
Distinguishing Characters: Forms lacking comb-fibrils may be confused with Sphagnum palustre and S. henryense. Both of these species, however, have branch leaf chlorophyll cells much narrower in transverse section and stem leaves lacking divided hyaline cells (at least in eastern North America forms). In the field $S$. imbricatum is often recognizable by its slender aspect and branch leaves that are frequently squarrose. When intimately mixed with other section Sphagnum species, $S$. imbricatum is nearly always paler.

Importance: Seldom abundant where found, but appears to have previously been a major peat former in boreal mires (Green, 1968).

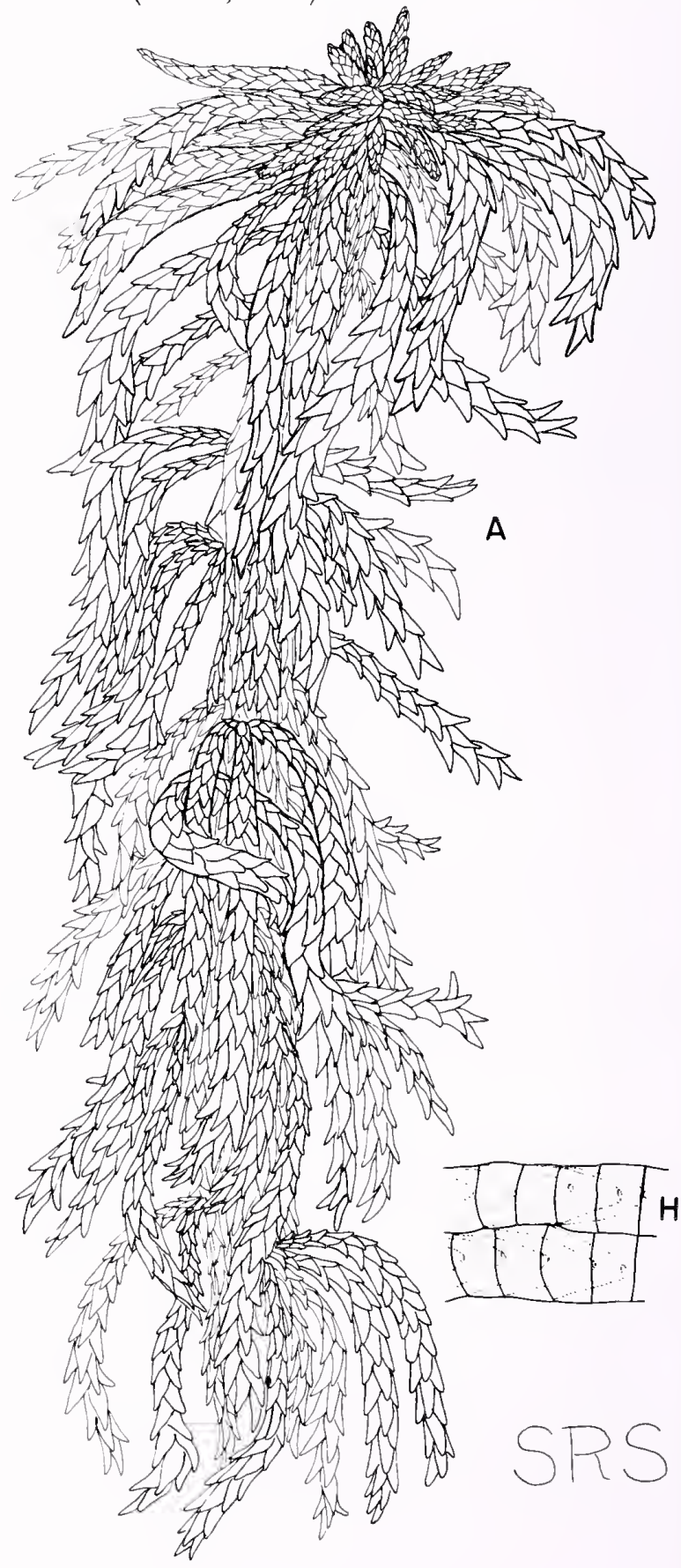


elliptic pores along the commissures of the convex surface; chlorophyll cells in transverse section equilateral-triangular with the base on the concave surface and the apex typically well enclosed on the convex surface; hyaline cell walls (where overlying chlorophyll cells) with comb-fibrils, these more prominent at the leaf base (rarely absent); pigmentation brown; plants variegated green and brown to golden brown.
Distinguishing Characters: One of the few Sphagna easily recognizable macroscopically. The branches, especially in the capitulum, have a distinct slenderly clavate shape that is unmistakable once seen. Microscopically, the unusual branch cortical cells separate it from S. imbricatum.

\section{SECTION RIGIDA}

Description: Stem cortex 1-3 layers of enlarged, thin-walled, efibrillose, and aporose cells; stem leaves small and triangular-lingulate, fringed across the apex and finely denticulate on the sides, border strongly broadened basally; hyaline cells rhomboidal, efibrillose, and rarely divided; branch cortex of \pm uniform and retort-shaped cells; branch leaves ovate to elongate-ovate, \pm abruptly involute above to a broadly truncate, toothed and sometimes slightly cucullate apex, margin borderless and denticulate; hyaline cells on the convex surface with \pm 5 small to medium-sized free pores, sometimes with numerous pseudopores and on the concave surface with large pores in the cell angles; chlorophyll cells in transverse section elliptic to ovate-triangular, completely enclosed or exposed on the concave surface; pigments brown and red.
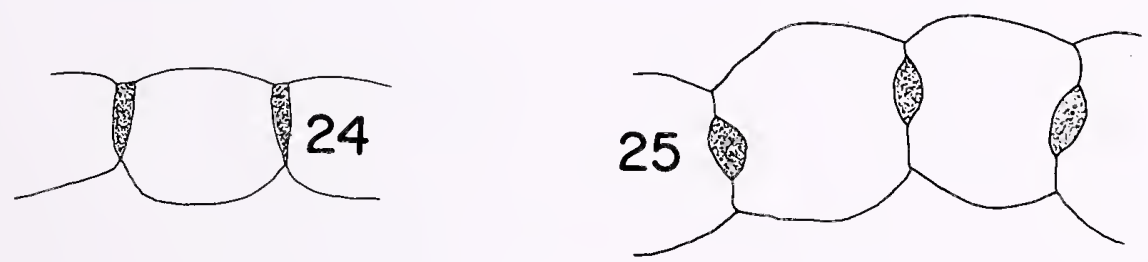

\section{KEY TO SPECIES OF SECTION RIGIDA}

1. Branch leaf chlorophyll cells in transverse section ovate-triangular, enclosed on the concave surface and broadly exposed (Fig. 24); hyaline cell walls typically minutely papillose where overlying chlorophyll cells; plants \pm lax, pale stemmed, whitish-green with the branch leaves nearly always squarrose............

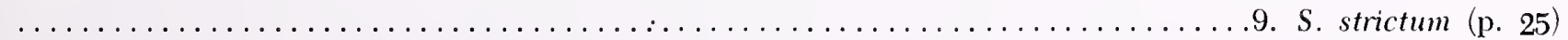

1. Branch leaf chlorophyll cells in transverse section elliptic, completely enclosed on both surfaces (Fig. 25); hyaline cell walls smooth where overlying chlorophyll cells; plants \pm compact, brown stemmed, brownish with the branch leaves often not squarrose $\ldots \ldots \ldots \ldots \ldots \ldots \ldots \ldots \ldots \ldots \ldots \ldots$. . compactum (p. 24) 


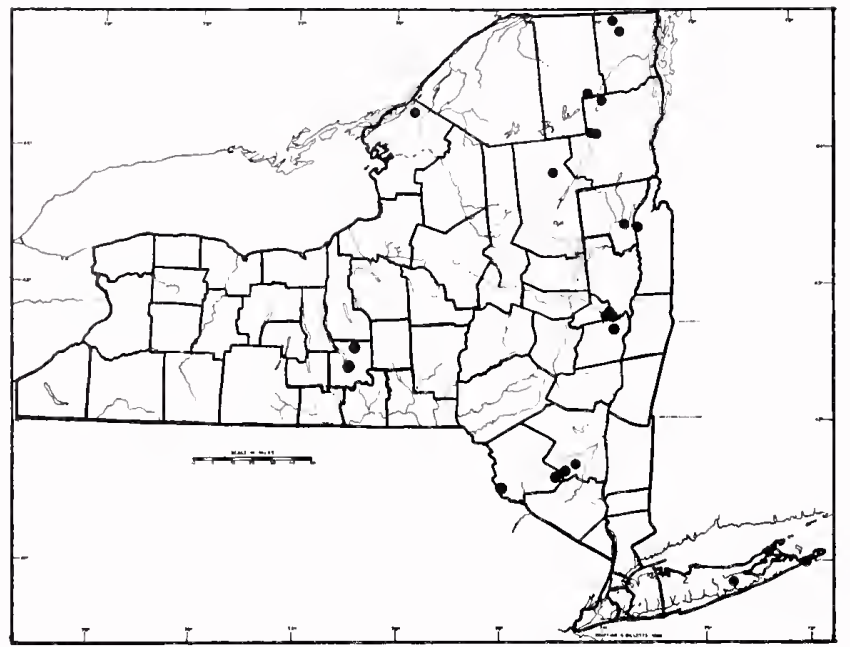

8. Sphagnum compactum DC.

Type Description: DeCandolle in Lamarck \& DeCandolle, Fl. Fr., 443, 1805.

Synonym: S, rigidum (Nees \& Hornsch.) Schimp.

Ecology: Ombrotrophic to weakly minerotrophic. A characteristic pioneer species over poorly drained sand, siliceous rock, and bare peat. Often found in fire climax vegetation, especially among Pinus banksiana and $P$. rigida. Also in seepage areas on cliff faces with Sphagnum lescurii and S. pylaesii.

Habit: Plants \pm moderate-sized, usually short and compact; simplex and subsimplex forms common. The species forms dense carpets or occasionally develops a lax habit over sloping, wet rocks.

General Distribution: Circumpolar: in North America from the arctic south to Georgia, Alabama, Tennessee, Missouri, Manitoba, Alberta and Washington.

Description: Stem brown; branch leaves imbricate, semi-squarrose, or squarrose, in shape ovate and \pm abruptly involute above to a tubular, sometimes slightly cucullate, apex, with the hyaline cells on the convex surface each with \pm 5 pores and numerous pseudopores along the commissures; chlorophyll cells elliptic in transverse section, centrally positioned and completely enclosed on both surfaces; hyaline cell walls smooth where overlying chlorophyll cells; pigments brown and red; plants pale green, brownishwhite, golden-brown or (in very exposed sites) variegated golden-brown and red.

Distinguishing Characters: See under S. strictum.

Infraspecific Variation: Some forms, particularly in shade, develop strongly squarrose branch leaves. Such forms may be separated from $S$. squarrosum by their small triangụlar stem leaves.

Importance: Can be locally important as an aggressive pioneer species over rock or thin peat.

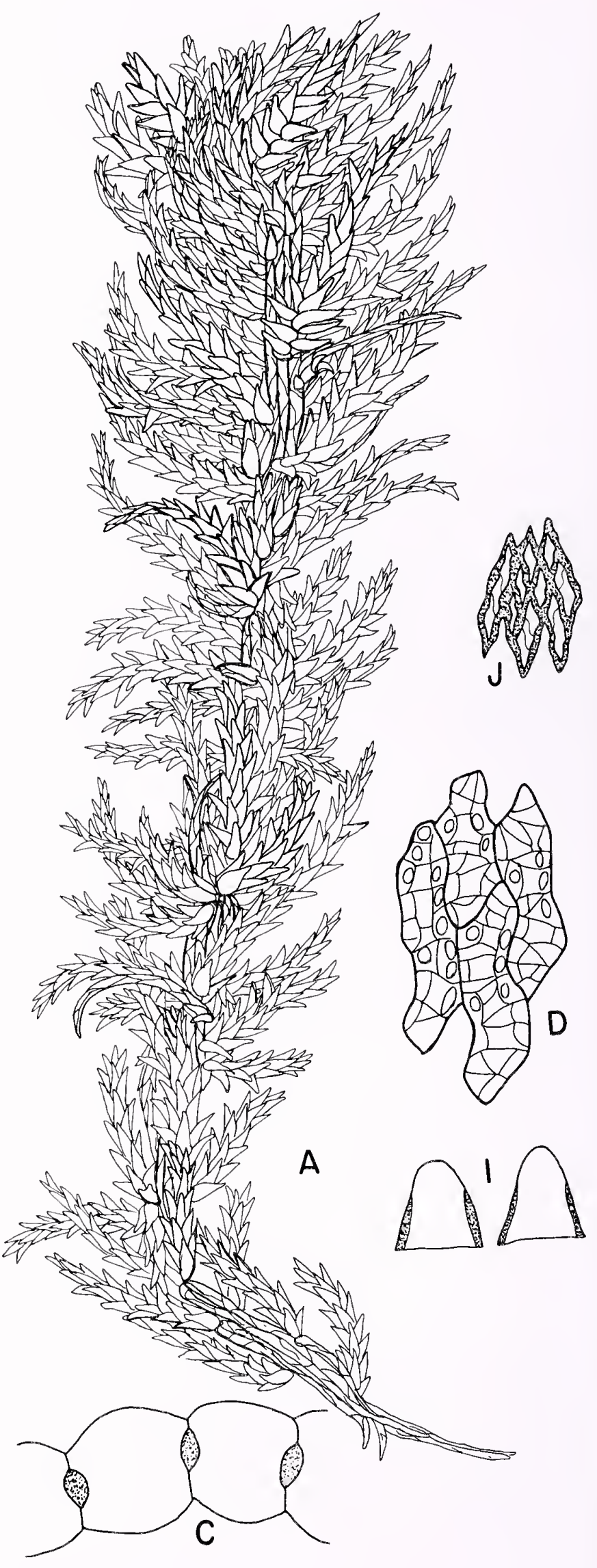




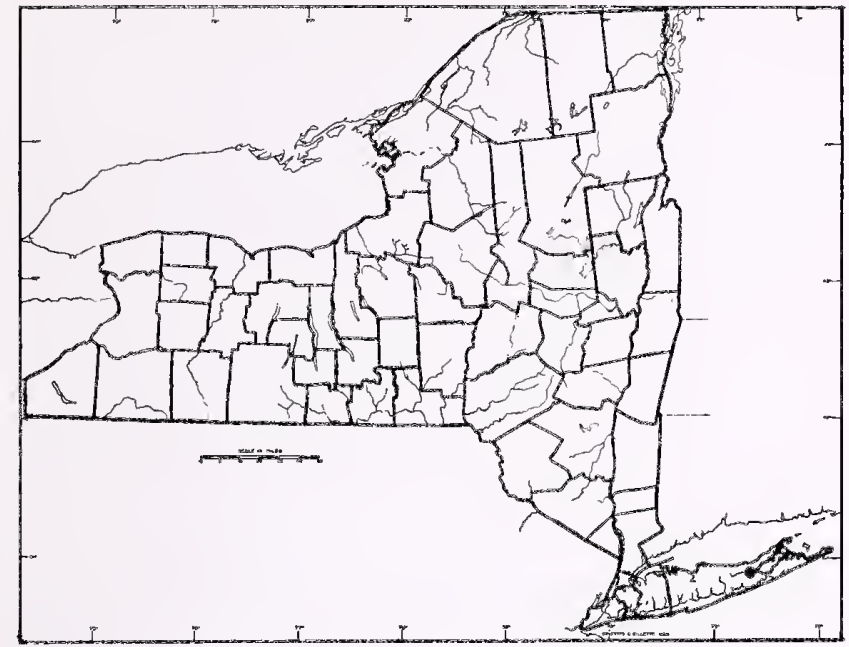

9. Sphagnum strictum Sull.

Type Description: Sullivant, Musci Allegh. 201, 1845. Synonym: S. Garberi Lesq. \& James

Ecology: Weakly minerotrophic. A pioneer species found around pond margins and on wet, bare organic soil.

Habit: Plants \pm moderate-sized, short and compact to more commonly larger, stiff and open (like a somewhat reduced form of $S$. squarrosum), forming loose to occasionally dense patches.

General Distribution: Amphiatlantic, oceanic (Isoviita, 1966). In North America near the coast from Newfoundland to Florida and Louisiana (Maass, 1966). Inland to western North Carolina and Arkansas. Also in Mexico, the West Indies, Venezuela and Ecuador (Maass, ibid).

Description: Stem pale brown or green; branch leaves strongly squarrose to infrequently slightly spreading, ovate to elongate-ovate, abruptly involute above to a long tubular apex; hyaline cells on the convex surface each with \pm 5 pores and normally 0 -few pseudopores; chlorophyll cells in transverse section ovate-triangular, broadly exposed on the convex surface and completely enclosed on the concave surface; hyaline cell walls minutely papillose (rarely smooth ?) where overlying chlorophyll cells; pigment brown; plants pale green, whitish-green or rarely golden-brown.

Distinguishing Characters: Although typical forms are easily recognized, atypical $S$. strictum is often confused with $S$. compactum. The only sure traits for separation of these two species are the branch leaf chlorophyll cell transverse section and the presence or absence of minute papillae on the hyaline cell walls where they overlap the chlorophyll cells. The papillae, found only in S. strictum, may be difficult to see and are best viewed in branch leaf cross sections under high magnification. Some forms of $S$. strictum may

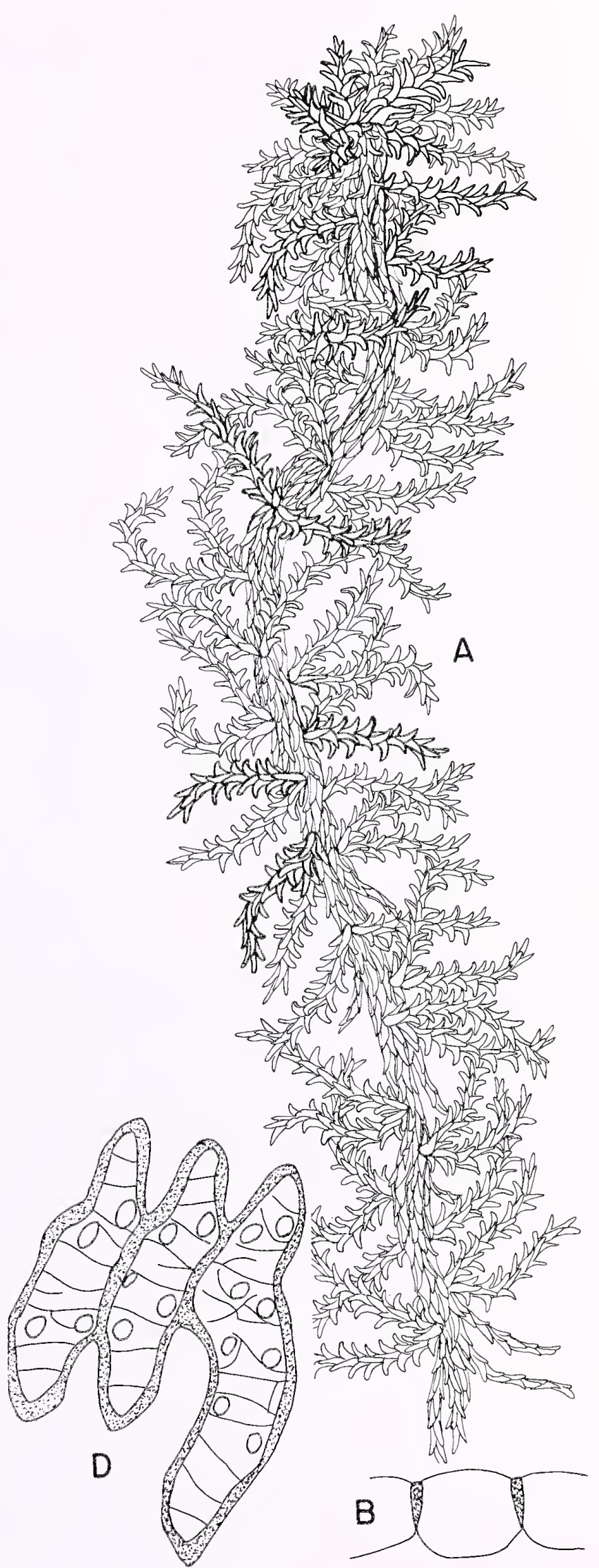


even lack them altogether. Sphagnum strictum also typically has the branch leaf convex surface with larger pores and few or no pseudopores while in typical $S$. compactum the pores are somewhat smaller and the pseudopores numerous. These characters, however, are of limited usefulness as they apply only to welldeveloped plants. A wide range exists in variability in the branch leaf pore patterns of $S$. compactum and $S$. strictum. Caution must also be applied to other characters often used to separate these two species such as color of stem cortex, compactness of growth habit and squarrosity of branch leaves. Sphagnum strictum may be separated in the field from the superficially similar S. squarrosum by its small, entire-margined, triangular stem leaves.

\section{SECTION SQUARROSA}

Description: Stem cortex 2-4 layers of enlarged, thin-walled cells, the outer layer often with I round to half-round wall-thinning per cell; stem leaves lingulate, apex broadly rounded and fimbriate, border narrow and present only basally; hyaline cells short-rhomboidal, efibrillose, aporose, and undivided with cell walls mostly resorbed on outer leaf surfaces, but on inner surfaces resorbed in apical regions only; branch leaves ovate, ovate-hastate or ovatelanceolate, involute above to a narrowly truncate and toothed apex, border entire, both surfaces with large, round pores in the cell ends and along the commissures; chlorophyll cells in transverse section triangular to trapezoidal, more broadly exposed on the convex surface; pigment brown.

\section{KEY TO SPECIES OF SECTION SQUARROSA}

1. Plants robust, branch leaves almost invariably squarrose throughout; color typically pale green, rarely dark

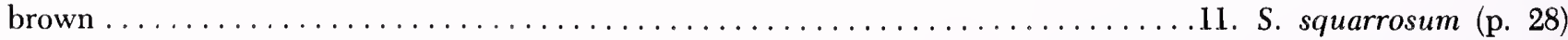

1. Plants \pm moderate-sized; branch leaves normally imbricate above, but often squarrose in small shade forms and lower portions of open grown plants; color rich brown in sun-grown forms to pale green in shade forms

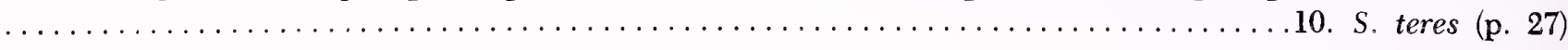




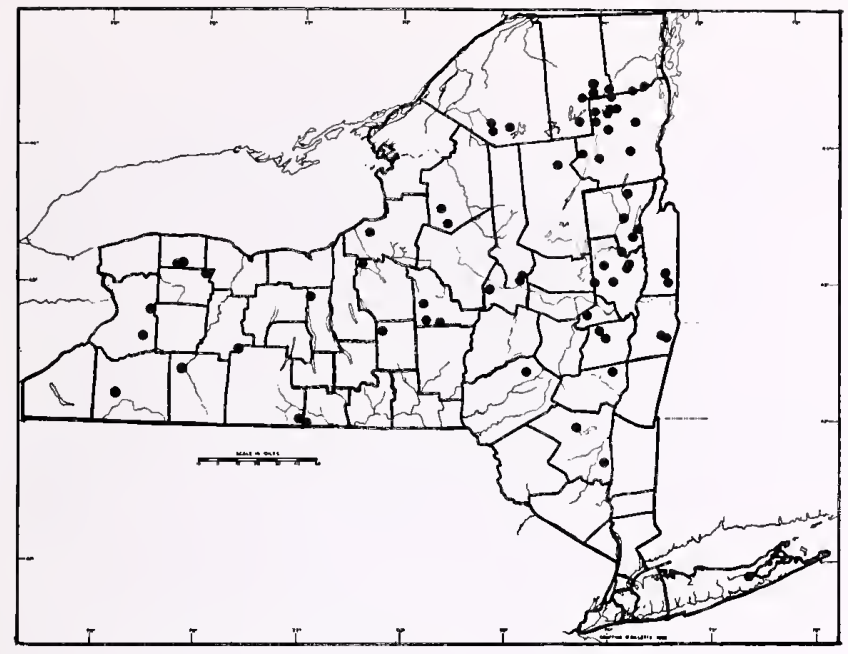

10. Sphagnum teres (Schimp.) Ångstr.

Type Description: Ångström in C. Hartman, Skand. F. ed. 8, p. 4127, 1861.

Ecology: Strongly minerotrophic. In open, medium to rich fens associated with Sphagnum centrale, S. imbricatum, S. subsecundum, S. fimbriatum, and S. warnstorfii. Less frequently in rich, wooded mires with Thuja occidentalis and Abies balsamea, usually in small clearings and often mixed with Sphagnum squarrosum and $S$. centrale. A characteristic species of rich weakly acid to slightly basic mires.

Habit: Plants small to moderate-sized, slender to moderately stout, not especially stiff, forming sparse to dense carpets.

General Distribution: Circumpolar: in North America from the arctic south to Pennsylvania, Ohio, Michigan, Illinois, Iowa, North Dakota, Colorado, Montana, Idaho and California.

Description: Stem slender to moderately thick, pale green to dark reddish-brown; stem cortical cells 3-4 layers thick; branch leaves ovate to ovate-lanceolate, imbricate on sun-grown forms, but frequently squarrose in shade forms and on lower portions of open grown forms; pigment brown; plants green to reddishbrown.

Distinguishing Characters: Sphagnum teres, in its characteristic sun-grown form, is a rich reddish-brown plant with imbricate branch leaves while S. squarrosum, in New York, is a very robust plant with strongly squarrose branch leaves, and usually pale green.

Infraspecific Variation: A rather variable species with shade forms often having squarrose branch leaves. Such squarrose forms can be separated from $S$. squarrosum by their smaller size. This squarrosity is often a useful field character in separating $S$. teres from other small, nondescript green sphagna. 


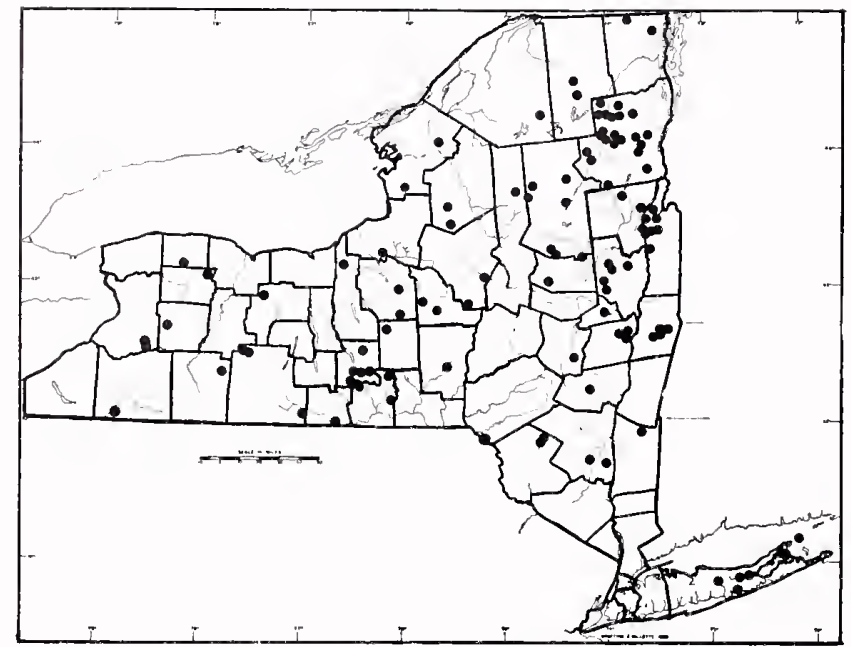

\section{Sphagnum squarrosum Crome}

Type Description: Crome, Samml. Deuts. Laubm, p. 24, 1803.

Ecology: Minerotrophic. A characteristic species of poor to medium coniferous fens, typically associated with Sphagnum centrale, S. girgensohnii, S. russowii and S. wulfianum. Also common at margins of ponds and open mires. Very shade tolerant and rarely found in mire expanses.

Habit: Plants robust, open and stiff. Forming carpets on moist sites rather than at water level.

General Distribution: Circumpolar. In eastern North America common from the arctic south to New York and at higher elevations in the mountains to North Carolina and Tennessee; in the midwest south to Ohio, Michigan, Illinois, and Wisconsin and in western North America from Alaska south in the mountains to California, Arizona, Colorado and South Dakota.

Description: Stem thick, usually pale green, but occasionally brown; stem cortical cells 2-3 layers thick; branch leaves ovate-hastate to ovate, sharply squarrose; pigment brown; plants usually green, but infrequently yellowish-brown.

Distinguishing Characters: Usually an easily recognized species, but certain forms of S. palustre, S. imbricatum, and S. strictum and S. compactum, though differing sharply microscopically, may resemble it macroscopically. Sphagnum palustre and S. imbricatum can be separated by their cucullate branch leaves and $S$. strictum and $S$. compactum by their small, triangular, nonfimbriate stem leaves. For separation from $S$. teres, see that species.

Infraspecific Variation: Imbricate forms are frequent in tundra environments and can be difficult to distinguish from S. teres. Such forms, are, however, rare in New York.

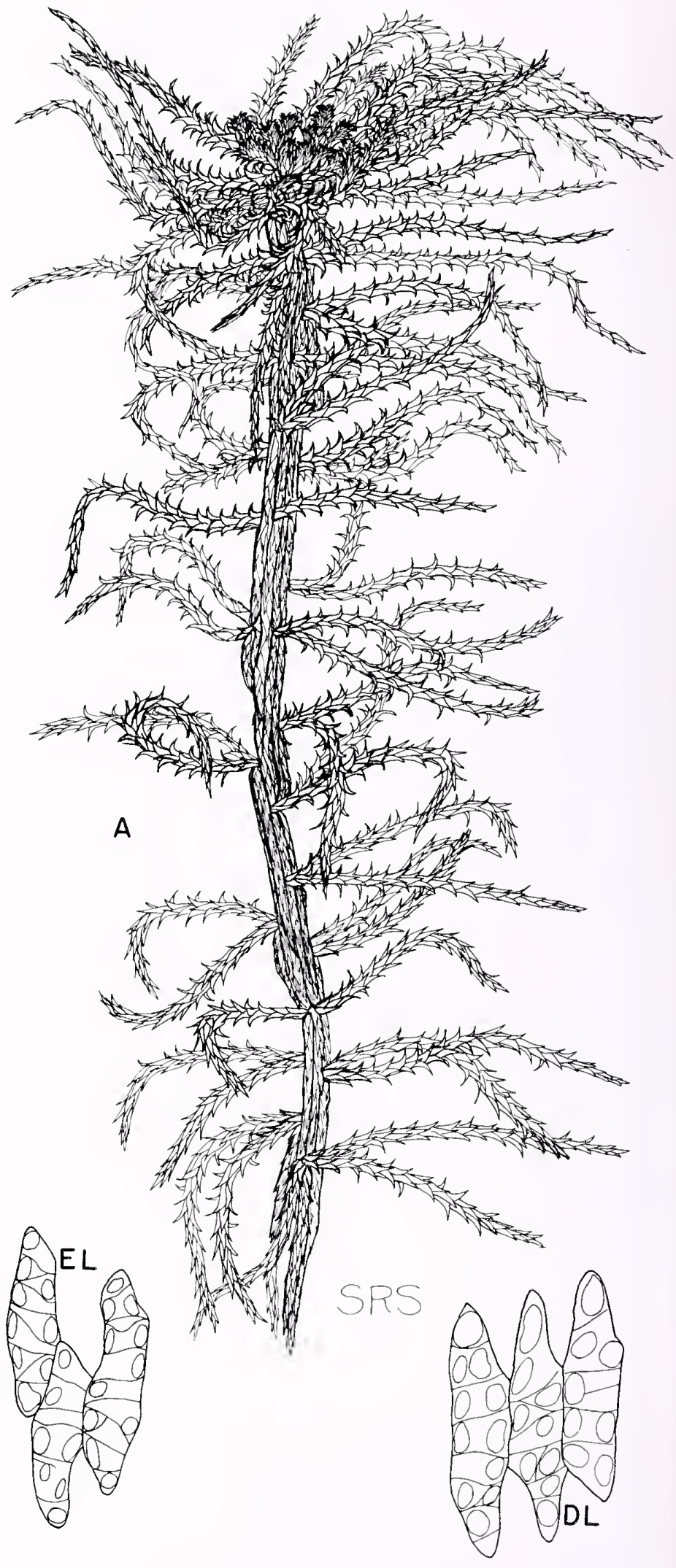




\section{SECTION SUBSECUNDA}

Description: Stem cortex 1-3 layers of enlarged, thin-walled cells with the outer layer often having 1 round to half-round wall-thinning per cell; stem leaves triangular-lingulate, lingulate or ovate, apex erose to denticulate. border strong and greatly broadened basally (in anisophyllous forms), hyaline cells efibrillose or fibrillose, undivided or divided, aporose or porose and, especially at the leaf apex, often with small pores at the cell ends and along the commissures; branch leaves broadly ovate to ovate-lanceolate, \pm involute above to a narrowly truncate and toothed apex, border entire; hyaline cells on the convex surface typically with a continuous row of small beadlike pores along the commissures in aquatic forms and S. pylaesii these reduced to a few pores at the cell in ends and on the concave surface aporose or with few to numerous pores as on the convex surface; chlorophyll cells in transverse section trapezoidal to ovate, equally exposed or more broadly exposed on either surface; pigmentation brown, less frequently red or dark, bluish-purple.
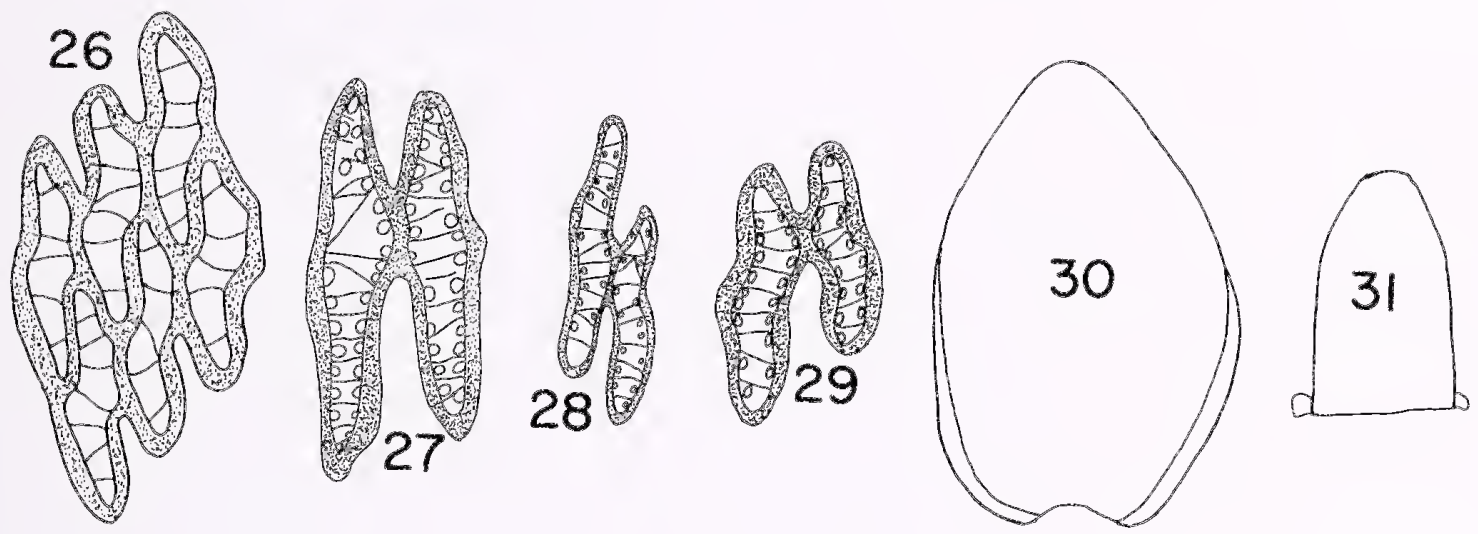

\section{KEY TO SPECIES OF SECTION SUBSECUNDA}

1. Branch leaf hyaline cells on the convex surface aporose or with membrane gaps near the leaf apex and a few end pores (Fig. 26); plants slender and unbranched or sparingly branched..........12. S. pylaesii (p. 31)

1. Branch leaf hyaline cells on the convex surface with numerous small pores in rows along the commissures (Fig. 27); pores sometimes reduced in aquatic forms but these plants much larger than $S$. pylaesii plants unbran-

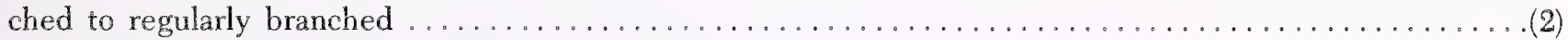

2. Plants simplex, the branching merely forkings of the stem ............ 15. S. platyphyllum (p. 36)

2. Plants with branches in fascicles (subsimplex forms occasionally found, these normally mixed with welldeveloped forms of the same species) . . . . . . . . . . . . . . . . . . . .

3. Stem leaves small $(0.5-1.0 \mathrm{~mm})$, normally porose and fibrillose at apex only; branch leaves subsecund; slender to moderate-sized hydrostable plants . . . . . . . . . . . . . . . . . . . . . . . . . . . .

3. Stem leaves medium-sized to large $(0.7-2.0 \mathrm{~mm}$ or larger), often porose and fibrillose in at least the apical half; branch leaves rarely subsecund; slender to large hydrolabile species ................... (5)

4. Branch leaf hyaline cells with very small pores (Fig. 28); stem cortex typically $2-3$ layered .........

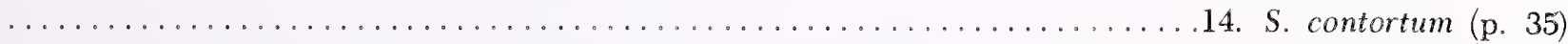

4. Branch leaf hyaline cells with larger pores (Fig. 29); stem cortex 1-2 layered.13. S. subsecundum (p. 34)

5. Slender, weak-stemmed plants with the terminal buds usually large and distinct; stem leaves (Fig. 30) large and broadly ovate, always fibrillose; stem cortex typically 2-3 layered, up to 3 branches per fascicle...... $\ldots \ldots \ldots \ldots \ldots \ldots \ldots \ldots \ldots \ldots \ldots \ldots \ldots \ldots \ldots \ldots \ldots \ldots \ldots \ldots \ldots \ldots \ldots \ldots \ldots \ldots \ldots \ldots$. S. platyphyllum (p. 36)

5. Moderate-sized to large, strong- to weak-stemmed plants with terminal bud not distinct; stem leaves (Fig. 31) small to large, lingulate to ovate (if ovate always more narrowly so than S. platyphyllum), sometimes fibrillose; stem cortex usually 1-layered; up to 5 branches per fascicle in nonaquatic forms ....16. S. lescurii (p. 32) 


\section{MULTIPLE-ACCESS KEY TO SPECIES OF SECTION SUBSECUNDA \\ Character \\ Character State}

\section{STEM CORTEX}

Differentiation of stem cortex

Stem leaf length

Stem leaf shape

Septation of stem leaf hyaline cells

Fibrillosity of stem leaf hyaline

cells in lower one half of leaf

Porosity of stem leaf hyaline cells

Number of branches/fascicle

Branch leaf habit

Branch leaf shape

Number of branch leaf convex

surface pores

Size of branch leaf convex

surface pores

Color (at least in part)

12. S. pylaesii; 13. S. subsecundum
1. One layer of enlarged thin-walled cells: all

2. Two layers of enlarged thin-walled cells: $12,14,15,16$

3. More than two layers of enlarged thin-walled cells: 14,15

\section{STEM LEAVES}

4. $\leq 1 \mathrm{~mm}: 12,13,14,16$

5. > 1mm: $14,15,16$

6. ovate to ovate-triangular: $12,15,16$

7. lingulate to lingulate-triangular: $13,14,16$

8. $>10 \%$ of cells divided: 14,16

9 . $\leq 10 \%$ of cells divided: all

10. efibrillose: $13,14,16$

11. fibrillose: $12,15,16$

12. aporose: $12,13,14,15$

13. porose in upper $1 / 3$ only: $13,14,15,16$

14. porose over more than upper $1 / 3: 12,15,16$

\section{BRANCHES}

15. $0-1: 12,15$

16. $2-5: 13,14,15,16$

\section{BRANCH LEAVES}

17. subsecund: $13,14,15,16$

18. not subsecund: $12,15,16$

19. ovate: $12,13,15,16$

20. ovate-lanceolate: $13,14,15,16$

$21 . \leq 2 /$ cell: 12

22. $>$ 2/cell: $13,14,15,16$

23. $₹ 2 \mu: 14,15$

24. $>2 \mu: 12,13,15,16$

\section{COLOR}

25. red: 12,16

26. brown or green: all

\section{SPECIES LIST}

14. S. contortum; 15. S. platyphyllum; 16. S. lescurii 


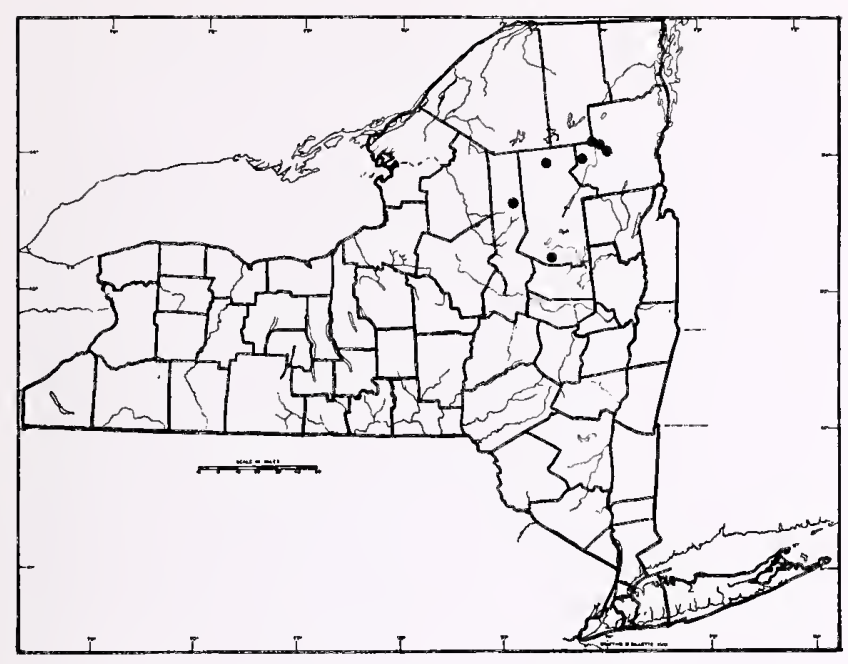

12. Sphagnum pylaesii Brid.

Type Description: Bridel-Brideri, Bryol. Univ. I, p. $749,1827$.

Synonym: S. sedoides Brid.

Ecology: Weakly minerotrophic. At higher elevations in the Adirondack Mountains, widely distributed as a pioneer species over wet rock, associated with Sphagnum tenellum and S. papillosum. Also occasionally found in poor fen pools, associated with $S$. papillosum, S. majus and S. pulchrum.

Habit: Plants slender and delicate, aquatic or prostrate. Unbranched forms common.

General Distribution: Amphiatlantic and coastal, with main distribution in North America (Isoviita 1966). In North America either along the coast or in mountains near the coast from Labrador to New Jersey with outlying stations at high altitudes in South Carolina, North Carolina and Tennessee. Also known from Colombia in South America (Maass, 1966).

Description: Stem pale green to brown with a cortex 1-2 layers of enlarged, thinner-walled cells; stem leaves broadly ovate, concave and isophyllous, very large in proportion to stem; hyaline cells long, narrow, undivided and fibrillose throughout, on the convex surface aporose or with membrane gaps at the leaf apex and a few pores at the cell ends (no more than 2 per cell) in the remainder of the leaf and on the concave surface with a few small pores in the cell ends and comers; branch leaves, when present, like the stem leaves but smaller, their chlorophyll cells in transverse section trapezoidal, exposed equally on both surfaces or somewhat more broadly on the concave surface; pigments brown and red; plants varying from a dark greenish- to purplish-brown in submerged plants to deep salmon-red in prostrate plants growing over exposed rock.

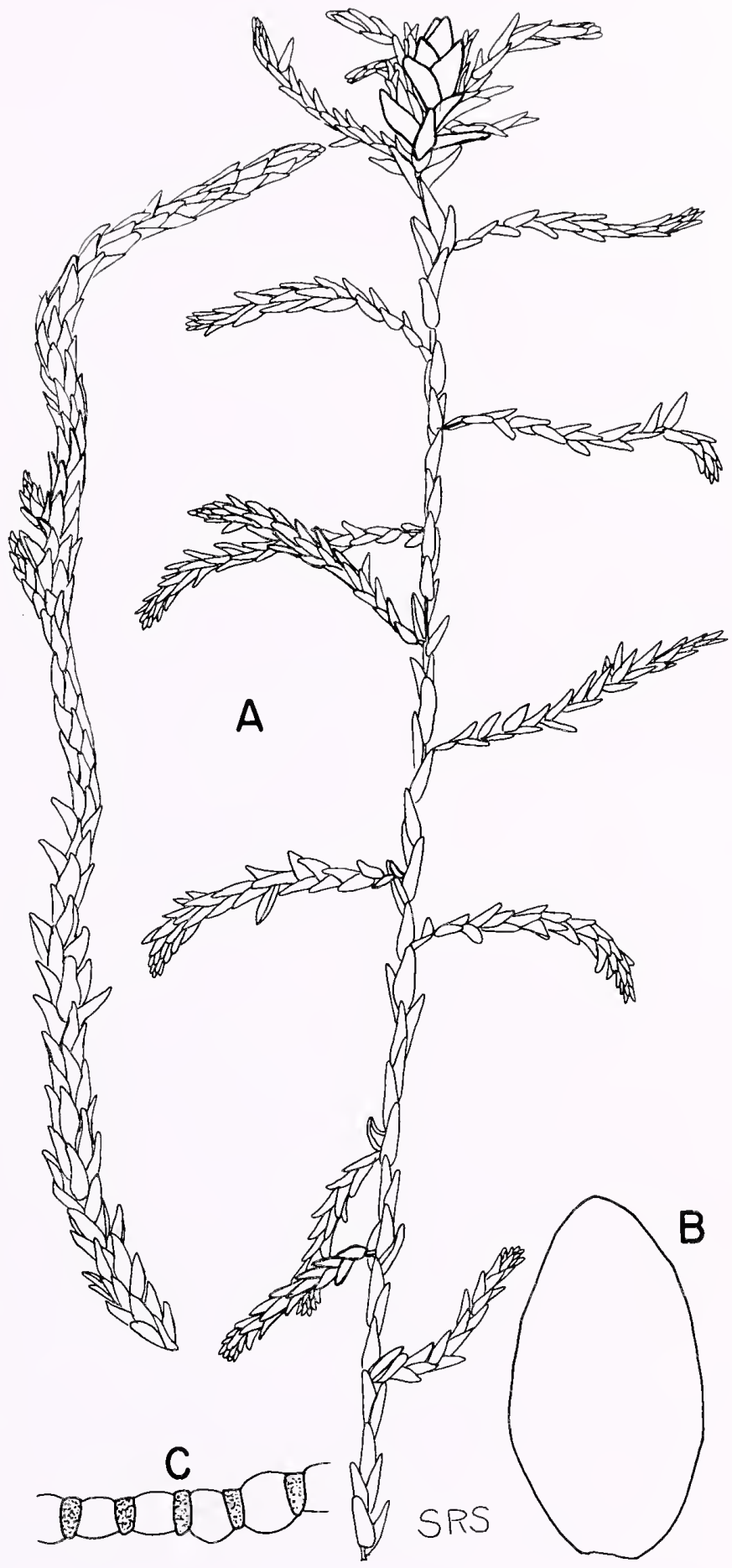


Distinguishing Characters: Because of the conspicuous terminal bud often found on aquatic S. pylaesii, confusion may occur with $S$. platyphyllum. However, $S$. platyphyllum is nearly always larger, has much larger branch leaves and has numerous pores in the hyaline cells of both branch and stem leaves.

Note: Sphagnum cyclophyllum Sull. \& Lesq. is an Atlantic coastal plain species with an unbranched growth form that resembles $S$. pylaesii. Since it is known from New Jersey and Nova Scotia, $S$. cyclophyllum may yet be found in Long Island. It is larger than S. pylaesii and has much more numerous branch leaf pores.

Infraspecific Variation: Some bryologists have recognized the branched and unbranched forms of $S$. $p y$ laesii as separate taxa-the unbranched form becoming

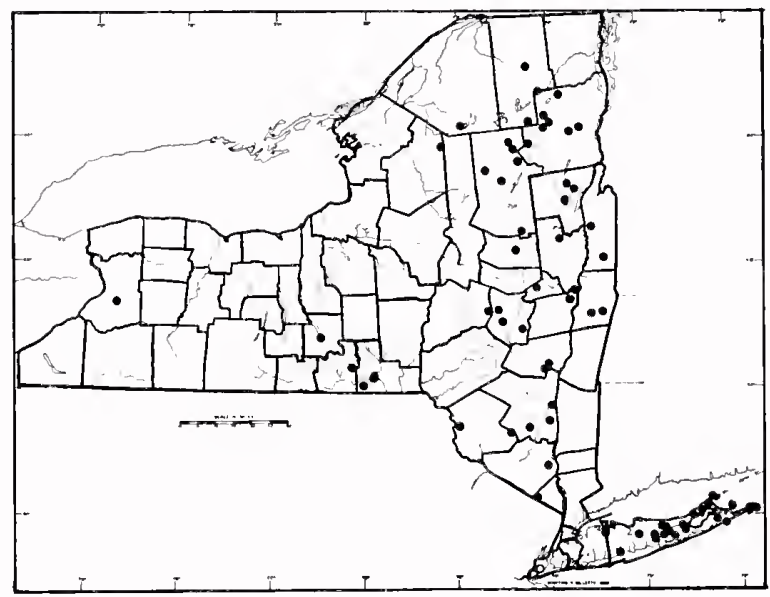

\section{Sphagnum lescurii Sull.}

Type Description: Sullivant in Gray's Man. Bot. Ed. 2, p. 611, 1856.

Synonyms: $S$. auriculatum Schimp, S. rufescens (Nees. \& Hornsch.) Warnst., S. obesum (Wils.) Warnst., S. gravetii Russow, S. bavaricum Warnst., $S$. inundatum Russow.

Ecology: Weakly minerotrophic. Found in a wide variety of slightly minerotrophic habitats, often of an aquatic or periodically dried character. Commonly submerged at stream, pond and mire margins. Also on dripping cliffs.

Habit: Plants highly variable; rarely small or, more commonly, moderate-sized to robust; upright, prostrate or aquatic. Forming thin to compact carpets when emergent.

General Distribution: Amphiatlantic. Distributional details unclear due to similarity between this and related species. Eastern North American northern range limit probably subarctic. South to Florida and Texas and inland to Michigan, Illinois, Missouri, Oklahoma and Arkansas. var. sedoides (Brid.) Lindb., and the branched form becoming the typical form or var. ramosum Warnst. It appears certain that these "varieties" represent morphological responses of the same genotype to different site factors and thus should not be recognized at the varietal level. The "var. seduides" seems to be an adaptation to sites where periodic dessication occurs. Unbranched S. pylaesii occurs frequently in such habitats in high mountain areas where it grows as the leading edge of vegetational mats extending over wet rock. Where it occurs as an aquatic, the branched or "var. ramosum" form is found. In high mountain habitats, however, it is invariably possible, by careful searching, to find stands containing both branched and unbranched forms as well as a continuum of intermediate forms.
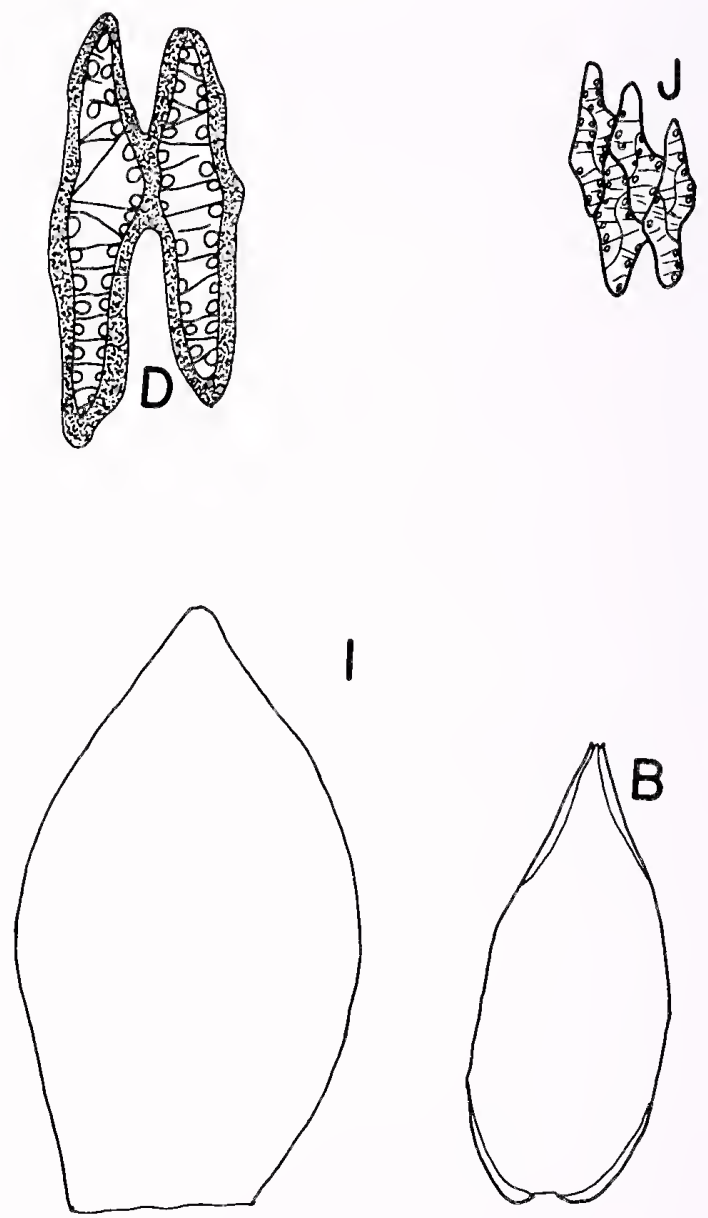
Description: Stem variable, ranging from pale green to brown in nonaquatic forms to dark brown in aquatic forms, its cortex 1 layer of enlarged thin-walled cells, occasionally with 2 layers in part (or rarely with 2 layers throughout) and often with 1 large pore-like wallthinning per cell; stem leaves medium-sized to large, $0.7 \mathrm{~mm}+$, usually $1.0 \mathrm{~mm}+$, varying from shortlingulate in anisophyllus forms to ovate-lingulate or ovate in hemisophyllous or isophyllous forms, apex truncate to rounded, usually denticulate; hyaline cells in anisophyllous forms rhomboidal, efibrillose, often 1-2 divided and porose near the apex (pores more frequent on the concave surfaces), with a continuous gradation to isophyllous forms which have hyaline cells long, narrow, S-shaped, fibrillose, undivided and porose nearly to the leaf base (pores less frequent on the concave surface); branch leaves broadly to narrowly ovate, in aquatic forms often greatly elongated at the branch tips, lax to imbricate, typically straight to infrequently subsecund or subsquarrose, concave in hygrophytic forms to flat in aquatic forms; hyaline cells on the convex surface with very numerous small pores and/or pseudopores in a continuous row along the commissures in aquatic forms these sometimes reduced to only a few pores in the cell angles and on the concave surface poreless or with a few pores in the cell angles, rarely with numerous pores and/or pseudopores as on the convex surface; chlorophyll cells trapezoidal, truncate-elliptic or ovate, usually exposed more broadly on the convex surface; pigments brown and red; plants green, pale yellow, goldenbrown, or dark brown, in exposed sites often \pm tinged with red and in aquatic forms sometimes purpletinged.

Distinguishing Characters: This species can normally be distinguished from other members of the section by the frequently divided stem leaf hyaline cells. Sphagnum contortum may also have such divided cells but has much smaller branch leaf pores. Slender sub. merged forms of $S$. lescurii can be field-separated from $S$. cuspidatum by their broader branch leaves and more rounded stem leaf apices. Robust submerged or emersed forms can be field-separated from members of section Sphagnum by their lack of cucullate branch leaves and lingulate unbordered stem leaves of that section.

Infraspecific Variation: As the list of synonyms would indicate, $S$. lescurii exhibits rather remarkable morphological variability; this apparently stems mainly from its great phenotypic plasticity and its common occurrence in sites of great hydrologic stress such as shorelines, ditches and mudflats. Genotypic variability cannot, however, be completely ruled out. Based upon stem leaf differences, some bryologists recognize two taxa within $S$. lescurii as follows:

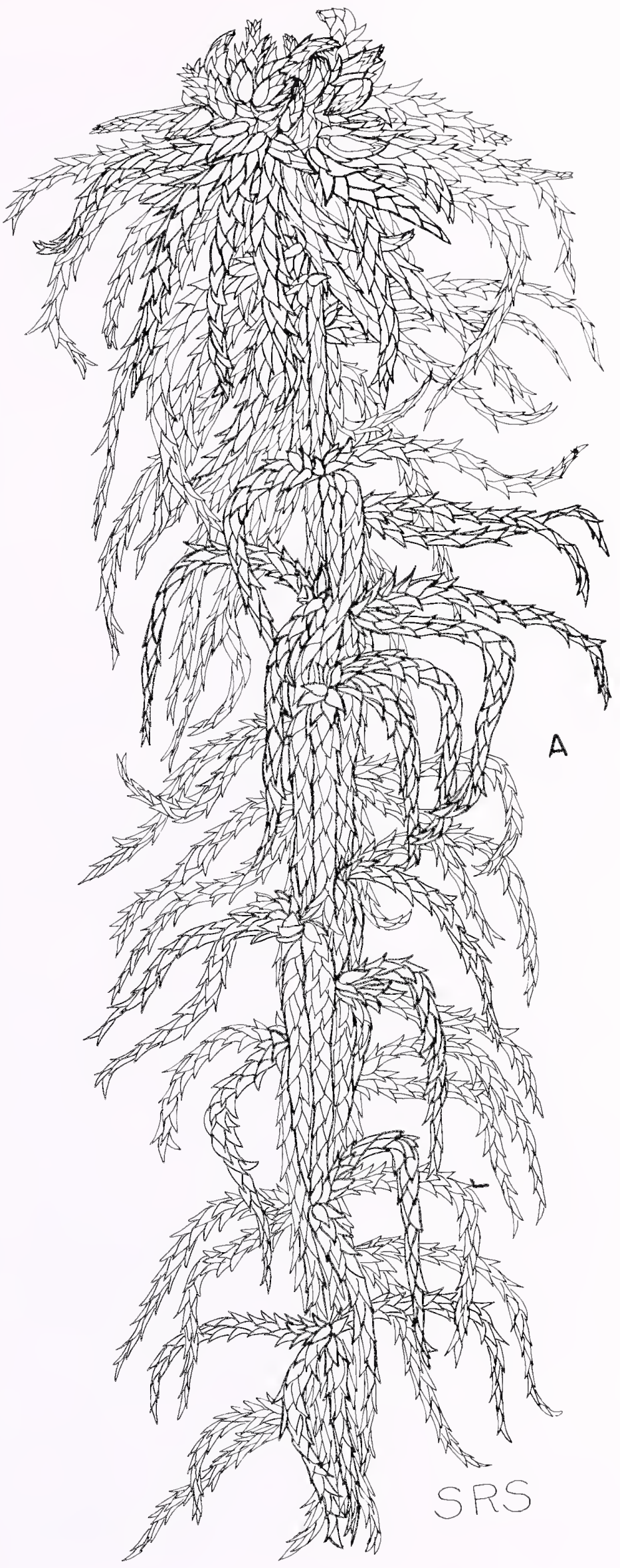



S. auriculatum
S. inundatum
stem leaves
stem leaves

Hyaline cells long, narrow

and S-shaped

Hyaline cells short rhombic

and mostly divided

Often fibrillose nearly to base

V'ery porose on convex surface, less so on concave

Usually fibrillose in upper half only

More porose on inner (concave) surface than on outer

Since the $S$. auriculatum stem leaf type is basically a hemiisophyllous to isophyllous modification of the $S$. inundatum type, synonymization under the earlier

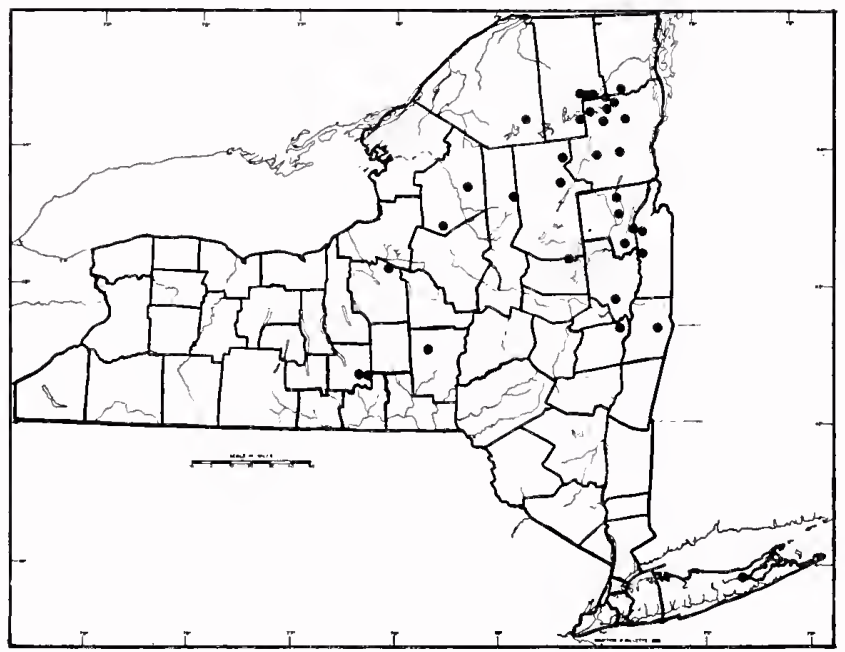

\section{Sphagnum subsecundum Nees}

Type Description: Nees von Esenbeck in Sturm, Deutschl. Fl. 2 (17): 3, 1819.

Ecology: Minerotrophic. Occurring near the edge of open, poor fens, often associated with Sphagnum centrale, S. palustre, S. teres, S. flexuosum, S. angustifolium, and S. fimbriatum. Less commonly found in open, medium fen mire-wide vegetation. Intolerant of shade and therefore rare in wooded mires.

Habit: Plants small, slender and often wiry; capitulum small, with terminal bud usually lacking. Forming low hummocks and patches of loose to thick carpet.

General Distribution: Circumpolar. In North America from the arctic south to North Carolina, Indiana, Illinois, Iowa, Minnesota, Montana and California.

Description: Stem light brown to dark brown, its cortex one layer of enlarged thin-walled cells which normally have 1 large pore-like wall-thinning per cell; stem leaves small, 0.5-0.8 $\mathrm{mm}$ long, triangularlingulate to lingulate, apex entire or weakly denticulate; hyaline cells undivided, efibrillose and aporose except at the very apex, hemiisophyllous forms rare; name $S$. lescurii seems reasonable. It should also be noted that $S$. auriculatum-type stem leaves are usually found on plants in periodically dessicated sites where such stem leaf modifications are to be expected. It is also possible to find single plants with all gradations of stem leaves from anisophyllous to isophyllous. Red pigment normally develops only on plants in exposed sites on cliff faces or muddy shorelines. Such plants often have a \pm prostrate growth habit, hemiisophyllous stem leaves and turgid, curved branches. This is perhaps the most easily recognizable form of the species.

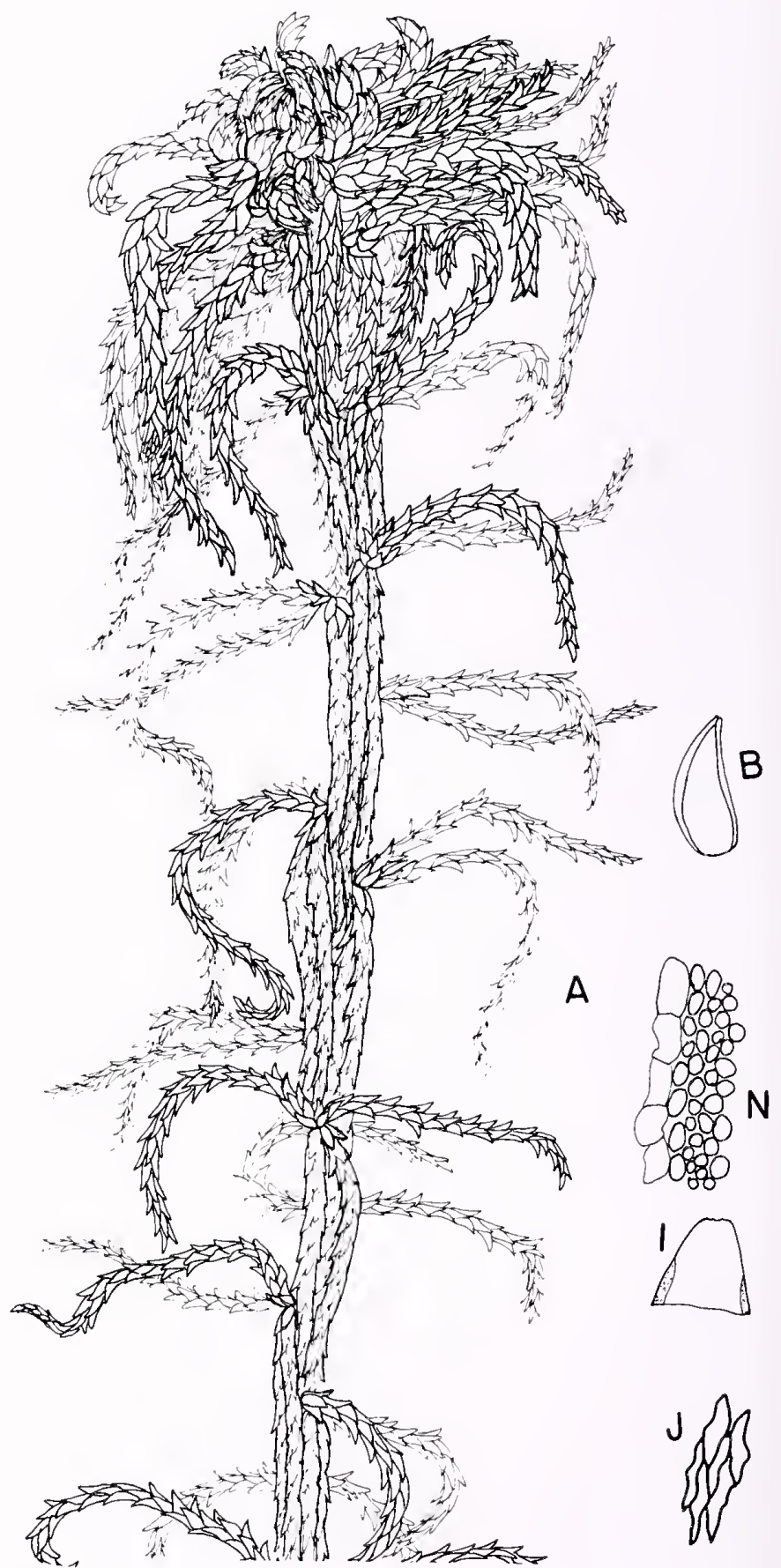


branch leaves small, broadly ovate to ovate-lanceolate, lax, subsecund, and often deeply concave; hyaline cells on the convex surface with very numerous small pores in a continuous row along the commissures and on the concave surface aporose or rarely with a few small pores along the commissures; chlorophyll cells trapezoidal, truncate-elliptic or ovate, usually exposed more broadly on the convex surface; pigment brown; plants green, yellow-brown or golden-brown.

Distinguishing Characters: Sphagnum subsecundum is normally a quite distinctive, small, slender and darkstemmed plant with very small, broad, subsecund branch leaves and short branches. Sphagnum contortum, with which it may be confused, is a larger, weaker-stemmed plant with a twomlayered stem cortex, paler stem, larger stem leaves and longer, narrow branch leaves with much smaller pores. There are occasional forms of $S$. contortum that have only one stem cortical layer but these are separable on other characters, especially the very small branch leaf pores. Such forms do not represent a transition to $S$. subsecundum but, simply an overlap of variation ranges in one specific character. Sphagnum lescurii is normally a larger plant and has larger stem leaves. Occasional small forms of S. lescurii can be troublesome and may have to be separated on other details, such as their less concave and less subsecund branch leaves.

Infraspecific Variation: In contrast to S. lescurii, S. subsecundum exhibits very little variation, only rarely developing hemiisophyllous stem leaves.

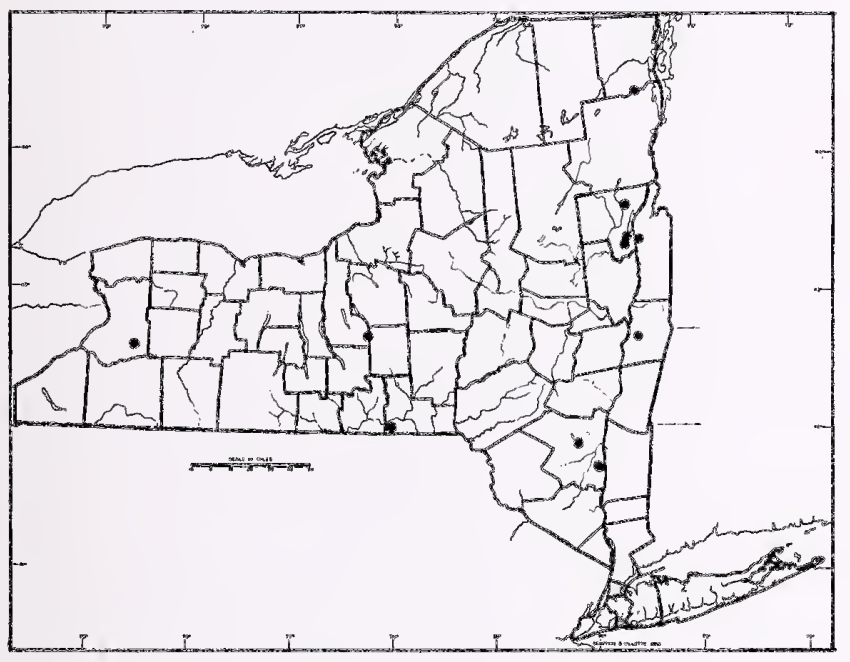

15. Sphagnum contortum K. F. Schultz

Type Description: K. F. Schultz, Prodr. Fl. Starg. Suppl. p. 64, 1819.

Ecology: Very minerotrophic. Perhaps our most minerotrophic species, occurring even in slightly basic mires. Intolerant of shade. A characteristic richfen species commonly associated with Sphagnum warnstorfii, $S$. centrale, Campylium stellatum and Calliergonella cuspidata.

Habit: Plants moderate-sized, often weak-stermmed and sprawling; capitulum typically large and flat, often with a small terminal bud. Forming low cushions or patches of loose to thick carpet.

General Distribution: Circumpolar, with slightly continental tendencies. North American distributional details unclear, but at least from the subarctic south to New York, Ohio, Indiana, Illinois, Wisconsin, Minnesota, Alberta, Washington and California.

Description: Stem pale green to light brown, rarely dark brown, its cortex 2-3 (rarely 1) layers of enlarged
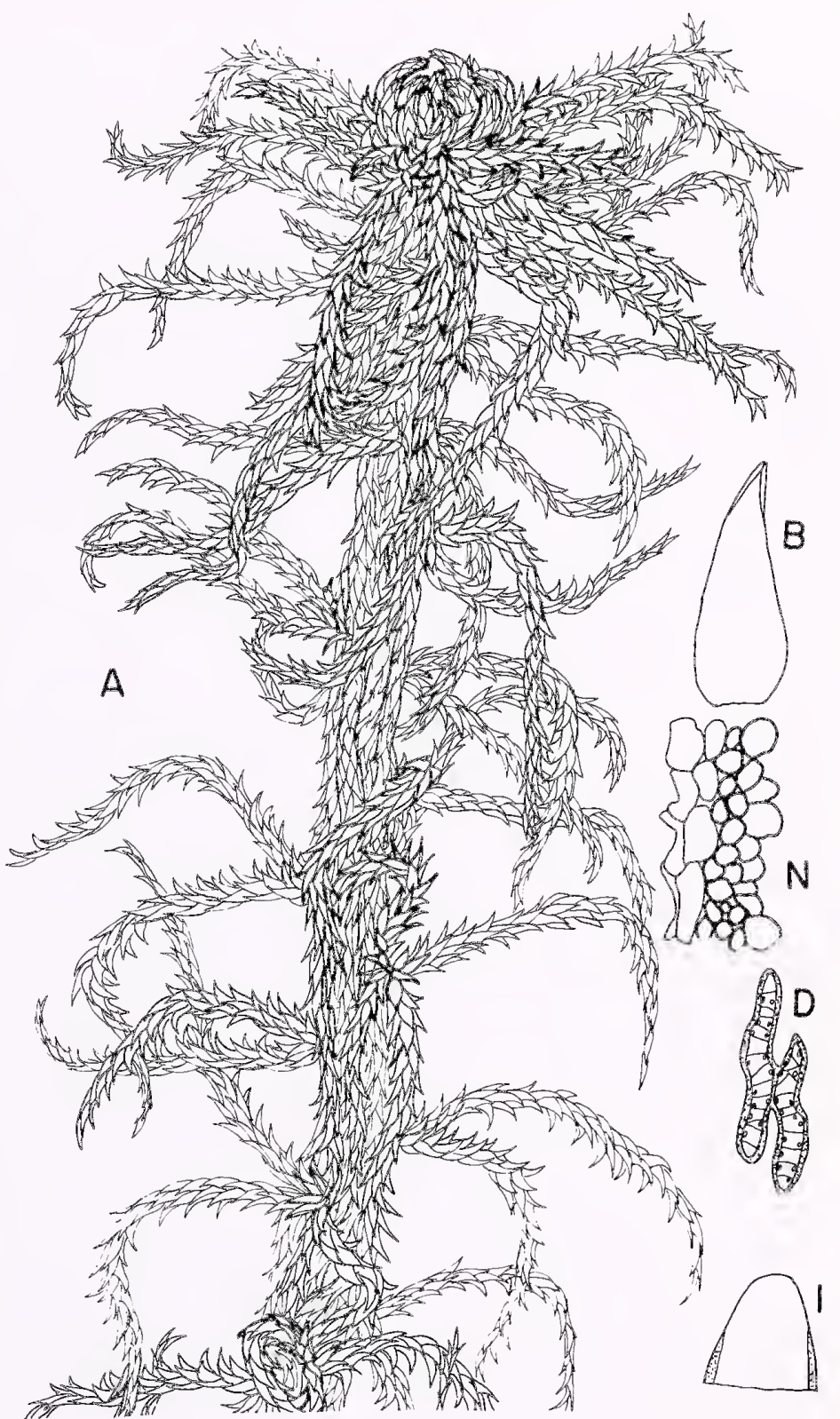
thin-walled cells with the outer layer usually having 1 large pore-like wall-thinning per cell; stem leaves moderate-sized, $0.7-1.0 \mathrm{~mm}$, triangular-lingulate to lingulate, apex weakly denticulate; hyaline cells efibrillose and aporose except near the apex, sometimes with few to many cells divided; hemiisophyllous forms rare; branch leaves small to moderate-sized, ovate to ovatelanceolate, laxly imbricate, \pm subsecund and concave; hyaline cells on the convex surface with very numerous tiny pores in a continuous row along the commissures and on the concave surface with 0 to few scattered pores along the commissures; chlorophyll cells in transverse section trapezoidal, truncate-elliptie or ovate, usually exposed more broadly on the convex

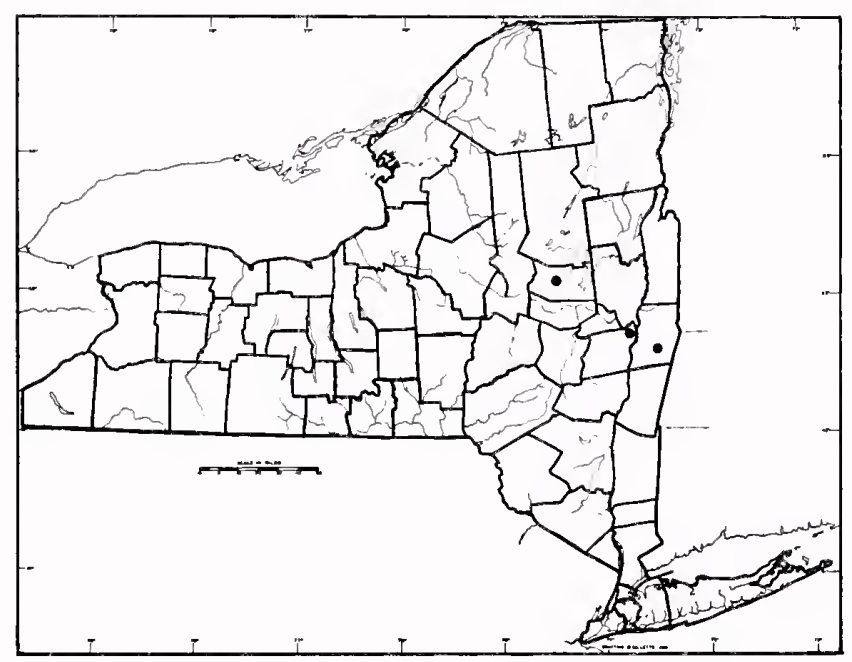

16. Sphagnum platyphyllum (Braithw.) Warnst.

Type Description: Warnstorf, Sphag. Eur., n. 187, 1884.

Ecology: Minerotrophic. Shores of lakes, ponds and streams and margins of open fens, especially seasonally flooded sites.

Habit: Plant small to moderate-sized, unbranched or sparsely branched (1-3 branches per fascicle) forms common; capitulum small with a large and conspicuous terminal bud. Forming open carpets with plants lax and often sprawling, or growing submerged.

General Distribution: Circumpolar, with slightly continental tendencies. In North America from the arctic south through Massachusetts, New York, New Jersey, Michigan, Illinois, Wisconsin, Minnesota, Alberta and British Columbia. South at high elevations to Montana, Wyoming, Arizona, and California.

Description: .Stem green to brown, its cortex 2-3 (rarely 1) layers of enlarged thin-walled eells with the outer layer often with 1 large pore-like wall-thinning surface; pigment brown; plants green, yellow-green, or golden-brown.

Distinguishing Characters: Because of its slender branches, golden-brown color and hydrophytic nature, S. contortum may be macroscopically mistaken for a member of section Cuspidata. The Cuspidata, however, are rarely found in highly minerotrophic habitats and, in any event, are easily separated microscopically by branch leaf pore characters (see also under S. subsecundum).

Infraspecific Variation: Sphagnum contortum, like $S$. subsecundum, is a hydrostable species. Sphagnum lescurii and S. platyphyllum, by contrast, are hydrolabile and vary greatly under different moisture regimes.

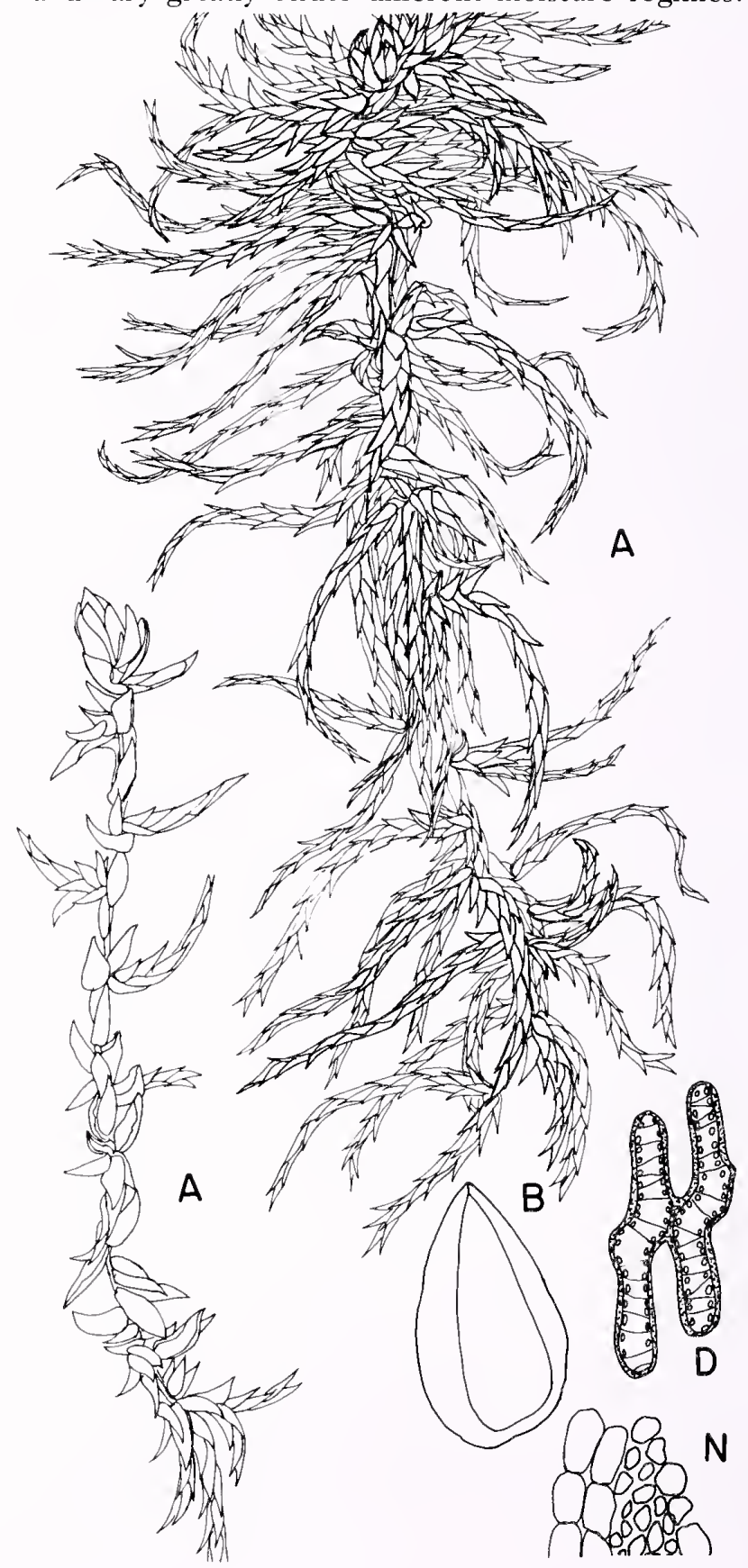


per cell; stem leaves large, concave and isophyllous; branch leaves medium-sized to very large, broadly ovate, strongly concave, and not subsecund, apex rounded; hyaline cells on the convex surface with numerous small to very small pores forming a continuous row along the commissures (these pores sometimes reduced or wanting) and on the concave surface aporose or with a few pores at the cell ends and along the commissures; chlorophyll cells in transverse section trapezoidal, truncate-elliptic, or ovate, usually exposed more broadly on the convex surface; pigment brown; plants grcen to brown.

Distinguishing Characters: Sphagnum platyphyllum is usually a distinctive species with its large terminal bud, short branches, slender stem and large, ovate, spreading stem leaves. Simplex and subsimplex forms (the so-called "juvenile" forms) of S. lescurii may be confused with it, but have no terminal bud, a onelayered stem cortex, and both branch and stem leaves are narrower and more pointed.

\section{SECTION ISOCLADUS}

A monotypic Section.

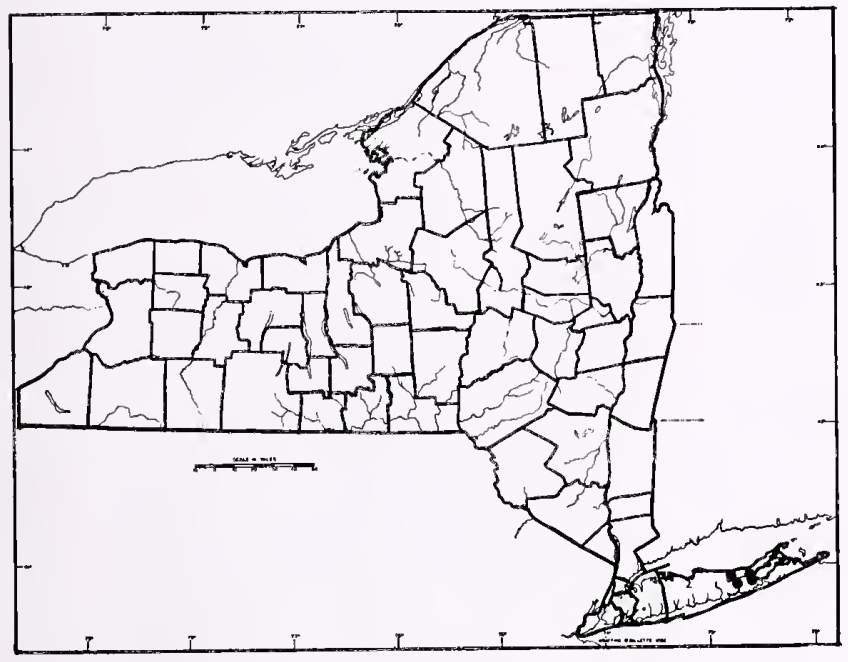

17. Sphagnum macrophyllum Brid.

Type Description: Bernhardi ex Bridel-Brideri, Bryol. Univ. I, p. 10, 1826.

Synonyms: S. floridanum (Aust.) Card., S. macrophyllum var. floridanum Aust.

Ecology: Weakly minerotrophic. Aquatic. On Long Island found floating in shallow, sandy-bottomed ponds mixed with $S$. torreyanum, S. cuspidatum, $S$. lescurii and S. trinitense. Farther south it may also be found emergent in very moist fen habitats.

Habit: Plants are normally large, aquatic and floating.

General Distribution: Endemic to the North American Atlantic coast. Near the coast of Newfoundland south to Florida and Texas and inland to eastern Tennessee and Arkansas.

Description: Stem cortex of 2-3 layers of enlarged thin-walled cells; stem leaves small, triangularlingulate, apex broadly rounded; hyaline cells rhom-

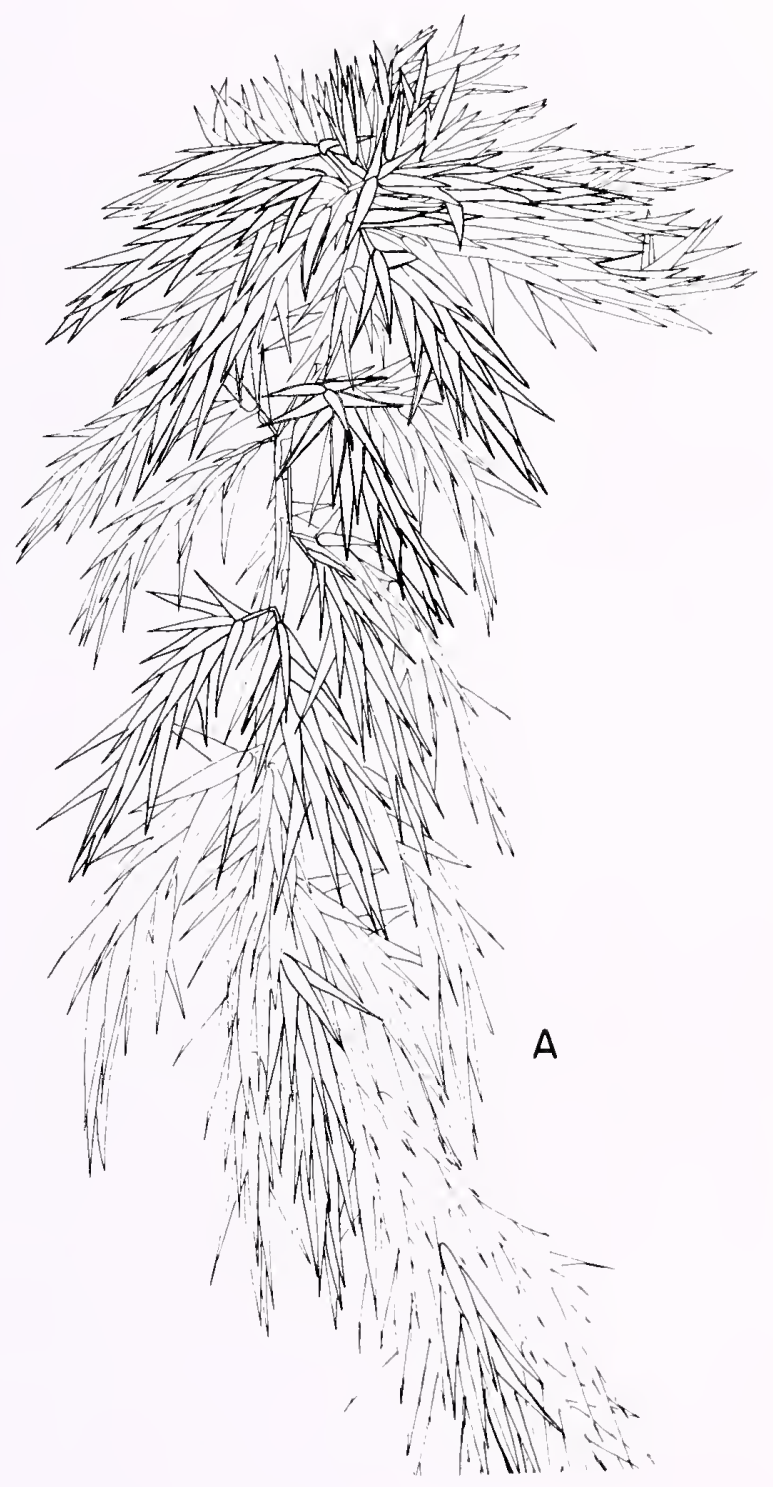


boidal, often divided, efibrillose and on the convex surface with 1-many pores per cell and the concave surface with 0 -few pores per cell; branches in fascicles of 1-3; cortex of 1-3 layers of \pm uniform aporose cells; branch leaves tufted toward the branch tips, lanceolate to lanceolate-linear, not undulate or recurved, apex long involute, border entire; hyaline cells efibrillose and very long and narrow, on the convex surface with $8-60$ or more small pores per cell in 1-3 irregular rows and on the concave surface nearly aporose; chlorophyll cells in transverse section rectangular and equally exposed on both surfaces; pigment brown; plants dark brown, greenish or silvery when living, with a metallic sheen when dry.

Distinguishing Characters: As our only completely efibrillose Sphagnum, S. macrophyllum is unmistakable microscopically. Macroscopically, it is easily recognized, when dry, by the long, narrow nonundulate and tufted branch leaves. Confusion is possible in the field with some dark aquatic forms of $S$, torreyanum, but branch leaves on the latter are not as tufted as those of S. macrophyllum.

Infraspecific Variation: Forms of S. macrophyllum differ markedly in numbers of branch leaf pores; taxonomic recognition has sometimes been given to forms of $S$. macrophyllum with more numerous branch leaf pores, either at the varietal level (var. floridanum Aust.) or the species level (S. cribrosum Lindb. or $S$. floridanum (Aust.) Card. Since intergrades exist and both forms plus intergrades can be found, even on the same plant, it seem best not to recognize any varieties.

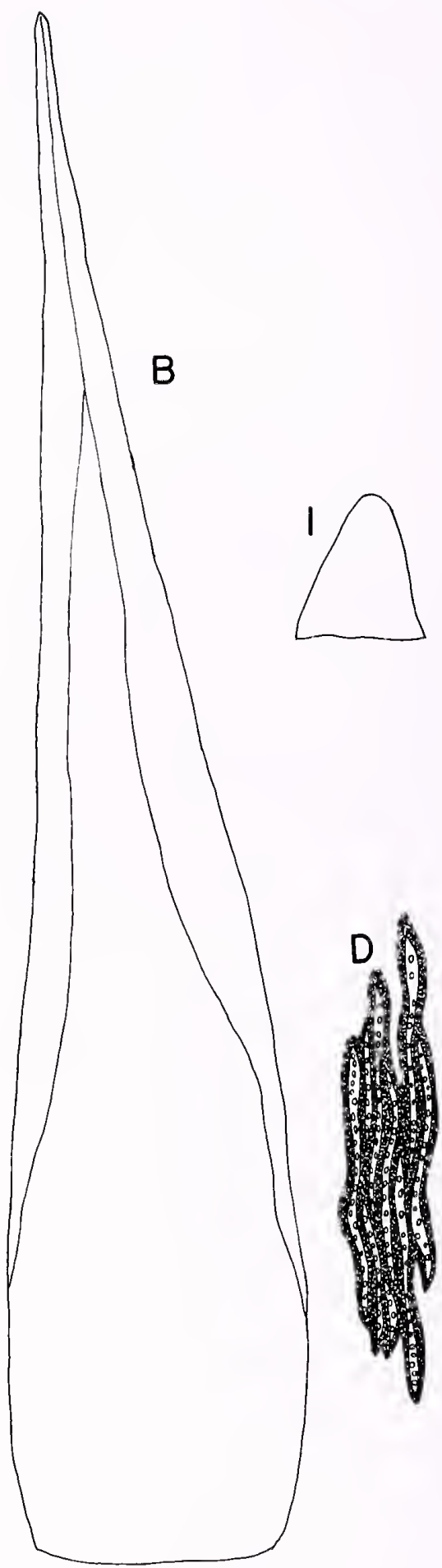




\section{SECTION CUSPIDATA}

Description: Stem cortex undifferentiated or of 1-4 layers of \pm enlarged and thin-walled cells, aporose; stem leaves triangular, triangular-ovate, triangular-lingulate, lingulate or spatulate, apex apiculate, entire, denticulate, fimbriate, or lacerate, border typically much broadened basally; hyaline cells normally efibrillose and aporose, sometimes 1-2 divided, hyaline cell walls often resorbed on the concave surface; branch leaves ovate to lanceolate-linear, I involute above to a narrowly truncate and toothed apex, border entire or serrulate; hyaline cells on the convex surface aporose (rarely) or with few to numerous pores and/or pseudopores and on the concave surface aporose or with pores or pore-like wall-thinnings; chorophyll cells in transverse section triangular to trapezoidal, the broad base exposed on the convex surface, hyaline cells smooth throughout; pigment brown, on some species red also.
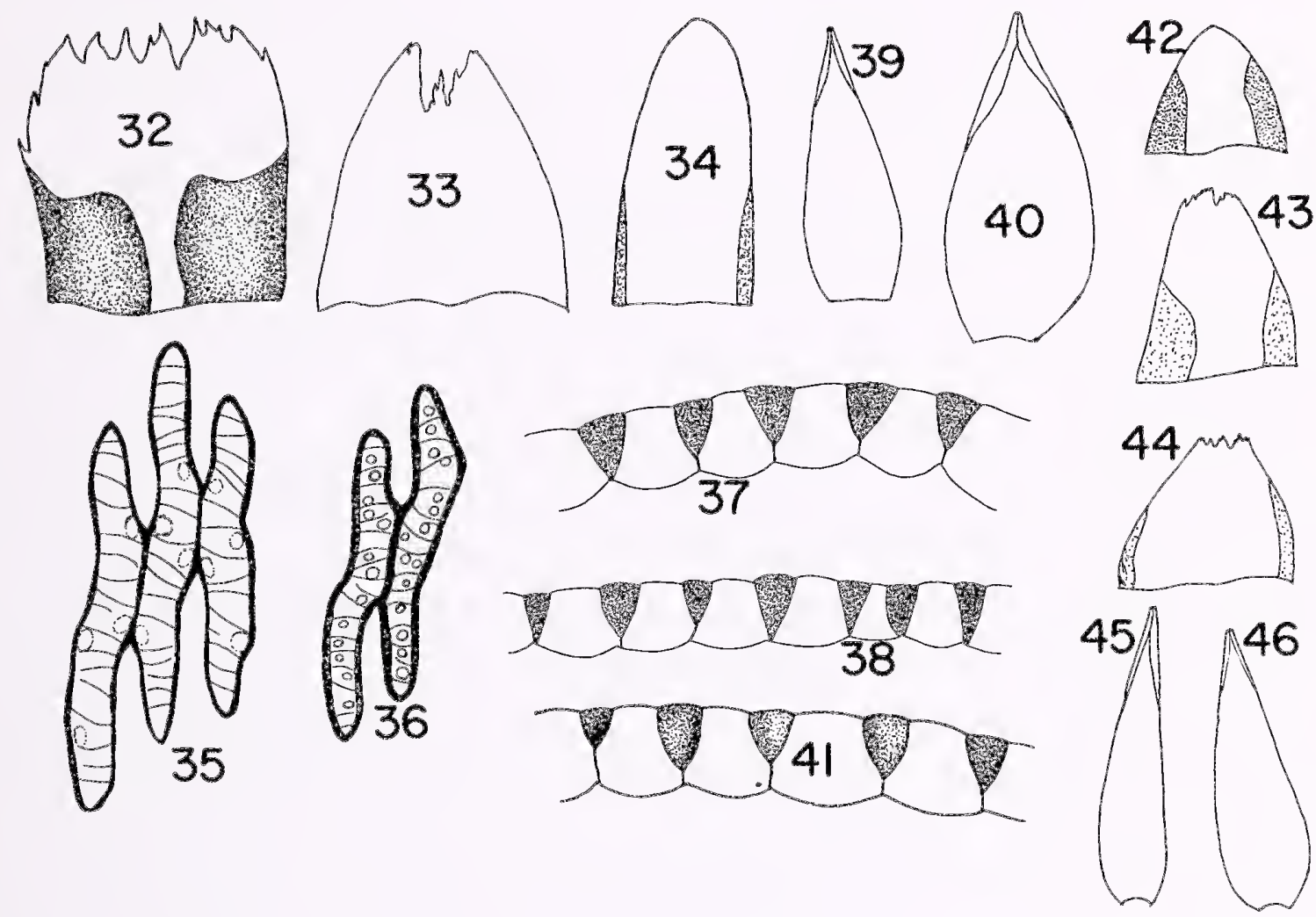

\section{KEY TO SPECIES OF SECTION CUSPIDATA}

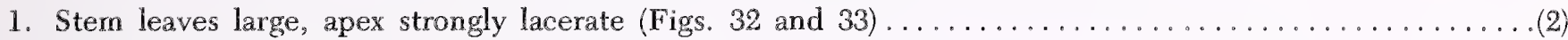

1. Stem leaves small to moderately large, apex entire, denticulate, erose or weakly fibrillose ...........(3)

2. Stem leaves broadly spatulate, lacerate across the broad apex (Fig. 32) .......19. S. lindbergii (p. 43)

2. Stem leaves triangular-lingulate, apex with a deep rent (Fig. 33) .........20. S. riparium (p. 44)

3. Branch leaves small, ovate, strongly concave, not undulate, not recurved, and without a long involute apex; stem leaves ovate-lingulate (Fig. 34), as large as branch leaves and normally fibrillose in at least the apical half

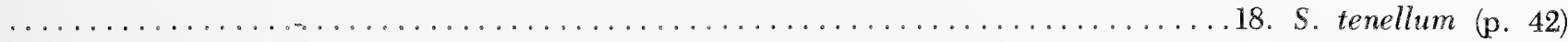

3. Branch leaves large, ovate to lanceolate-linear, slightly to moderately concave and usually undulate and/or recurved; stem leaves triangular to lingulate, smaller than branch leaves, and normally efibrillose .......(4)

4. Convex surface of branch leaf hyaline cells with numerous small pores free from the commissures; on the concave surface aporose or also with small, to moderate-sized pores free from the commissures (S. majus

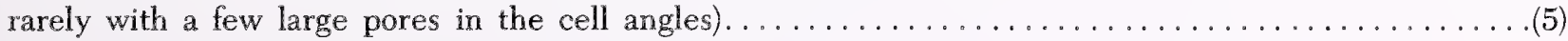

4. Convex surface of branch leaves with a few moderate-sized pores or few to numerous pseudopores at the cell ends and along the commissures; on the concave surface with moderate-sized to large, round, porelike, wall-thinnings in the cell angles (Fig. 35). 
5. Hyaline cells of branch leaf aporose on the concave surface (very rarely with a few large round wall-thinnings

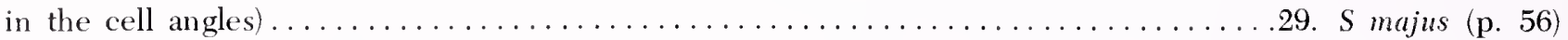

5. Hyaline cells of branch leaf hyaline cells on the concave surface with numerous moderate-sized pores free from

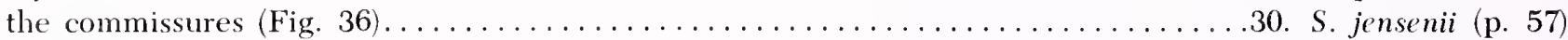

6. Branch leaves greatly elongated toward the branch tips; plants weak-stemmed and typically aquatic...(7)

6. Branch leaves not greatly elongated toward the branch tips; stronger stemmed and rarely aquatic ....(9)

7. Chlorophyll cells of branch leaf in transverse section mostly enclosed on the concave surface (Fig. 37); stem leaves typically obtuse; plants robust ......................... torreyanum (p. 55)

7. Chlorophyll cells of branch leaf in transverse section mostly exposed on the concave surface (Fig. 38); stem leaves typically acute to mucronate; plants slender to moderate-sized $\ldots \ldots \ldots \ldots \ldots \ldots \ldots \ldots \ldots$. $\ldots \ldots$ (8)

8. Branch leaves strongly serrate to weakly serrulate; stem leaves with many hyaline cells divided; stem cortex undifferentiated; head branches imbricate .................. S. trinitense (p. 54)

8. Branch leaves entire to weakly serrulate; stem leaves with hyaline cells only rarely divided; stem cortex typically clearly differentiated; head branches with recurved leaf tips.......26. S. cuspidatum (p. 52)

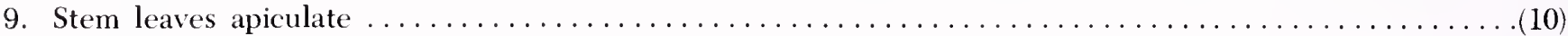

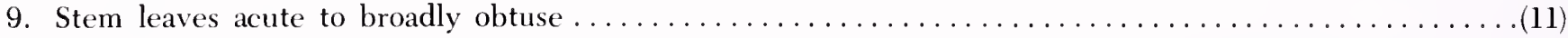

10. Branch leaves ovate-lanceolate, apex not abruptly pointed (Fig. 39), when dry always recurved but never subsecund; chlorophyll cells in transverse section slightly exposed to slightly enclosed............ .25. S. fallax (p. 51)

10. Branch leaves broadly ovate to ovate-lanceolate, apex abruptly pointed (Fig. 40), when dry often subsecund but seldom recurved, chlorophyll cells in transverse section typically well enclosed on the concave

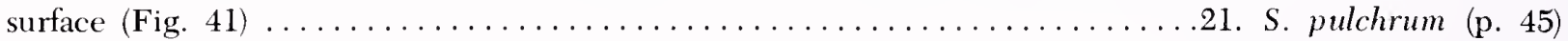

11. Stem leaves small $(0.5-0.8 \mathrm{~mm}$ ) and broadly triangular (Fig. 42), apex acute to obtuse and often weakly denticulate; stem frequently pinkish; open grown plants often quite brown....24. S. angustifolium (p. 49)

11. Stem leaves larger $(0.7 \mathrm{~mm}$ or more) and narrowly triangular, triangular-lingulate or lingulate (Figs. 43, 44), apex obtuse and erose to weakly fibrillose; stem never pinkish; open grown plants usually pale yellowish-

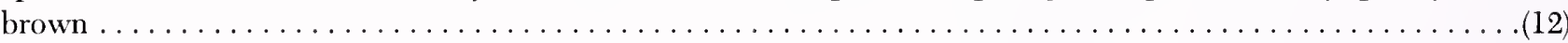

12. Branch leaves narrowly ovate-lanceolate (Fig. 45) and typically sharply 5-ranked, chlorophyll cells in transverse section enclosed on the concave surface; stem cortex clearly differentiated; plants quite often robust

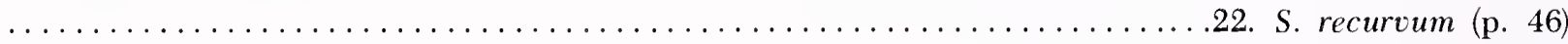

12. Branch leaves broadly ovate-lanceolate (Fig. 46) and only rarely 5-ranked, chlorophyll cells in transverse section exposed on the concave surface; stem cortex poorly differentiated; plants small to moderatesized 


\section{MULTIPLE-ACCESS KEY TO SPECIES OF SECTION CUSPIDATA}

\section{Character}

Differentiation of stem cortex

Stem leaf length

Stem leaf apex

Stem leaf shape

Stem leaf hyaline cell septation (in anisophyllous forms)

Branch leaf shape:

Branch leaf habit:

Branch leaf margin:

Branch leaf convex surface pores:

Branch leaf concave surface wall-thinnings

Branch leaf chlorophyll cell exposure on concave surface

Stem color
Character State

\section{STEM CORTEX}

1. 1 or more layers enlarged and differentiated cells: $18,19,21,22,25,26,28,29,30$

2. undifferentiated or poorly differentiated: $20,21,23,24,25,27$

\section{STEM LEAVES}

4. $\leq 0.7 \mathrm{~mm}: 24$

5. $>0.7 \mathrm{~mm}$ : all

6. apiculate: $21,25,26,28$

7. acute: $21,24,25,26,27,28,29,30$

8. obtuse and smooth: $18,24,27,28,29,30$

9. obtuse and erose: 22,23

10. broad, flat and lacerate: 19

11. with a deep, lacerate rent: 20

12. spatulate: 19

13. ovate-lingulate to lingulate: $18,22,23$

14. triangular-lingulate to triangular ovate: $20,21,22,23,25,26,27,28,29,30$

15. triangular: $21,24,25$

16. $<10 \%$ of cells divided: $18,21,22,23,24,25,26,29,30$

17. $10-50 \%$ of cells divided: $20,22,26,27,28$

18. $>50 \%$ of cells divided: $19,20,27,28$

\section{BRANCH LEAVES}

19. ovate: 18,21

20. ovate-lanceolate (length:width $\leq 5: 1$ ): $2-13$

21. lanceolate-linear (length:width $>5: 1$ ): 26-30

22. straight: $18,20,21,22,23,24,25,26,27,28$

23. falcate-secund: $19,21,26,27,28,29$

24. serrulate: 27

25. entire: all others

26. free from commissures: 29,30

27. along commissures: all others

28. free from commissures: 30

29. absent or along commissures: all others

30. well enclosed: 18, 21, 22, 28

31. just reaching surface: $18,19,20,21,22,24$, $25,26,28,29,30$

32. well exposed: 19, 20, 23, 25, 26, 27, 29, 30

\section{COLOR}

33. pink: 21,24

34. dark brown: 19

35. pale brown or green: $18,20,21,22,23,24$, $25,26,27,28,29,30$ 


\section{SPECIES}

18. S. tenellum; 19. S. lindbergii; 20. S. riparium; 21. S. pulchrum

22. S. recurtum; 23. S. flexuosum; 24. S. angustifolium; 25. S. fallax

26. S. cuspidatum; 27. S. trinitense; 28. S. torreyanum; 29. S. majus

30. S. jensenii
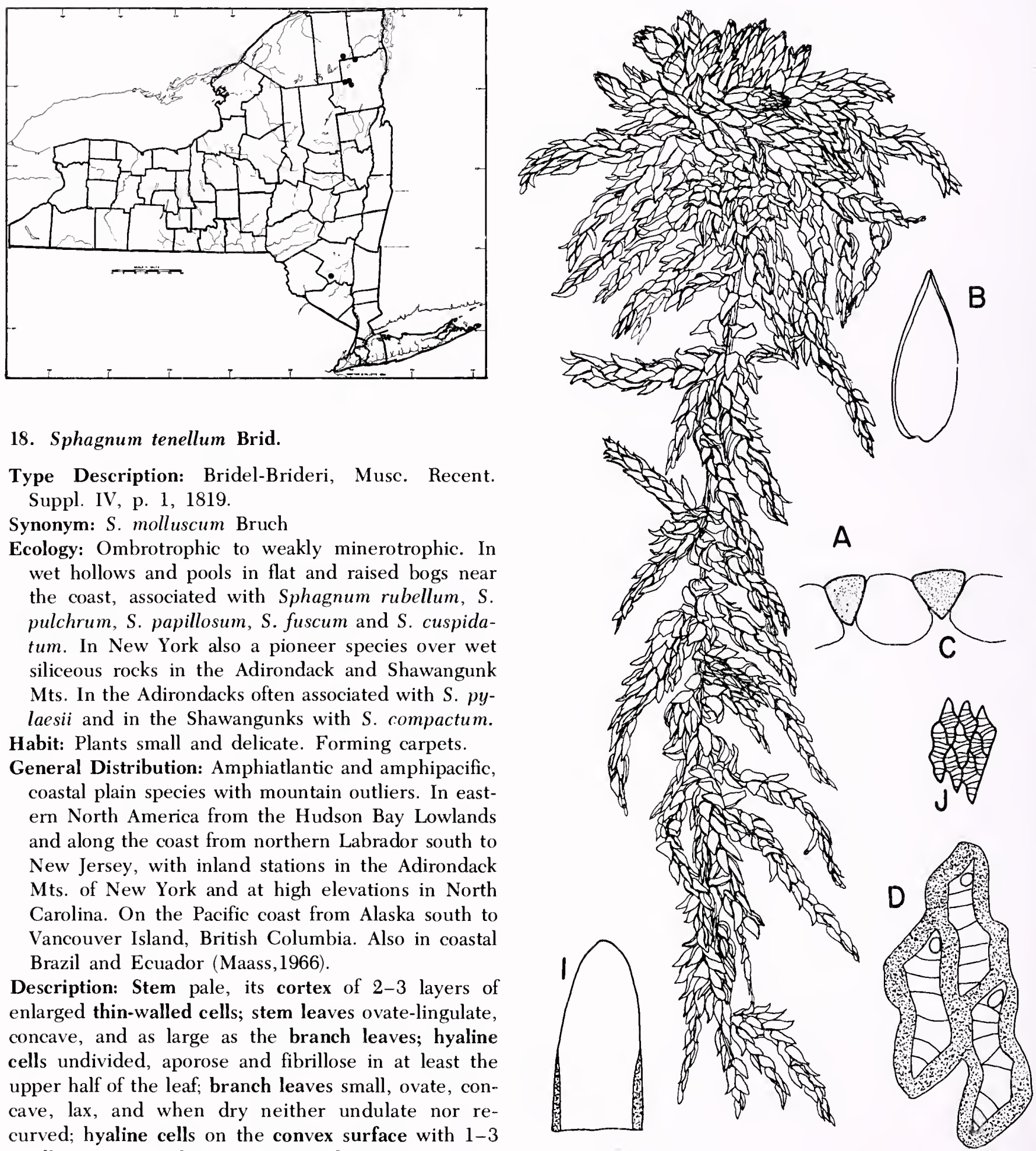

18. Sphagnum tenellum Brid.

Type Description: Bridel-Brideri, Musc. Recent. Suppl. IV, p. 1, 1819.

Synonym: S. molluscum Bruch

Ecology: Ombrotrophic to weakly minerotrophic. In wet hollows and pools in flat and raised bogs near the coast, associated with Sphagnum rubellum, $S$. pulchrum, S. papillosum, S. fuscum and S. cuspidatum. In New York also a pioneer species over wet siliceous rocks in the Adirondack and Shawangunk Mts. In the Adirondacks often associated with S. pylaesii and in the Shawangunks with S. compactum.

Habit: Plants small and delicate. Forming carpets.

General Distribution: Amphiatlantic and amphipacific, coastal plain species with mountain outliers. In eastern North America from the Hudson Bay Lowlands and along the coast from northern Labrador south to New Jersey, with inland stations in the Adirondack Mts. of New York and at high elevations in North Carolina. On the Pacific coast from Alaska south to Vancouver Island, British Columbia. Also in coastal Brazil and Ecuador (Maass, 1966).

Description: Stem pale, its cortex of 2-3 layers of enlarged thin-walled cells; stem leaves ovate-lingulate, concave, and as large as the branch leaves; hyaline cells undivided, aporose and fibrillose in at least the upper half of the leaf; branch leaves small, ovate, concave, lax, and when dry neither undulate nor recurved; hyaline cells on the convex surface with 1-3 small pores per cell at the apical ends and corners and 
on the concave surface with large round pore-like wall-thinnings in the cell angles; chlorophyll cells in transverse section equilateral-triangular, the apex slightly exposed to well enclosed on the concave surface; pigments brown and red; plants pale yellow to golden-brown, rarely tinged with red.

Distinguishing Characters: The only other species apt

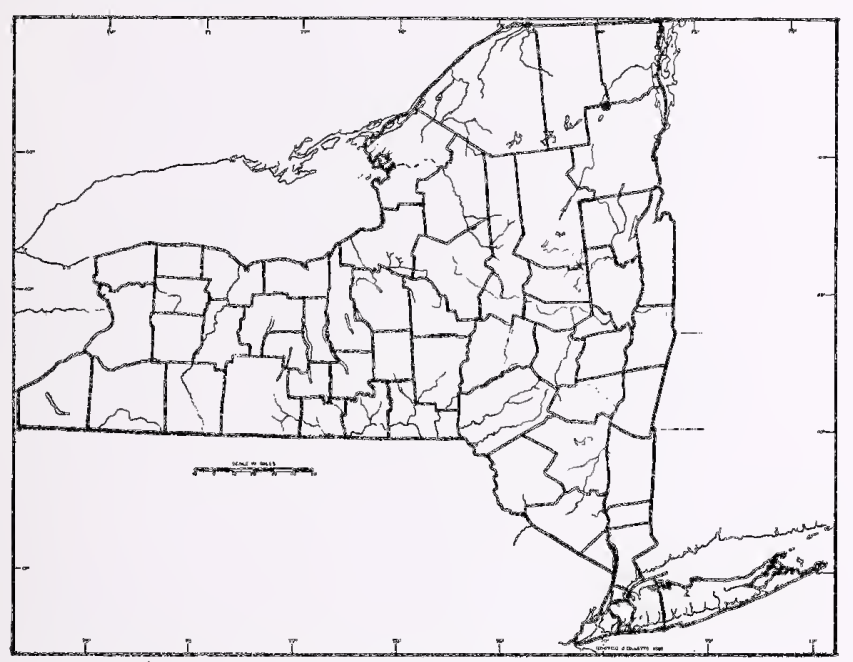

19. Sphagnum lindbergii Lindb.

Type Description: Schimper ex Lindberg, Ofvers. K. Svenska Vetensk-Akad. Förh. 19: 126, 1857.

Ecology: Ombrotrophic to weakly minerotrophic. In New York found only on one steep rock slide at high elevation in the Adirondack Mts. It is there associated with Sphagnum russowii and S. girgensohnii.

Habit: Plants moderate-sized to robust, forming \pm dense carpets.

General Distribution: Circumpolar. In North America from the arctic south to New Hampshire, New York and Washington. The conterminous U.S. locations are limited to 3 , all of these in isolated, highmountain sites.

Description: Stem dark brown, its cortex of 2-14 layers of enlarged thin-walled cells; stem leaves large, broadly spatulate and lacerate across the broad apex; hyaline cells often divided and normally efibrillose; branch leaves ovate-lanceolate, 5-ranked, imbricate to slightly lax and reflexed, I subsecund, and when dry sometimes weakly undulate; hyaline cells on the convex surface aporose or with a few small pores in the cell ends and angles, also often with numerous pseudopores along the commissures toward the leaf apex and on the concave surface with large pore-like wall-thinnings in the cell ends and angles; chlorophyll cells in transverse section triangular to trapezoidal, the apex often exposed on the concave surface; pigment brown, plants green to brown, often with a bluish gloss when dry. to be confused even macroscopically with $S$. tenellum is $S$. subsecundum. The latter can be field-separated by its much smaller and flatter stem leaves, subsecund branch leaves and more minerotrophic habitats.

Importance: Often a major carpet former in coastal mires.

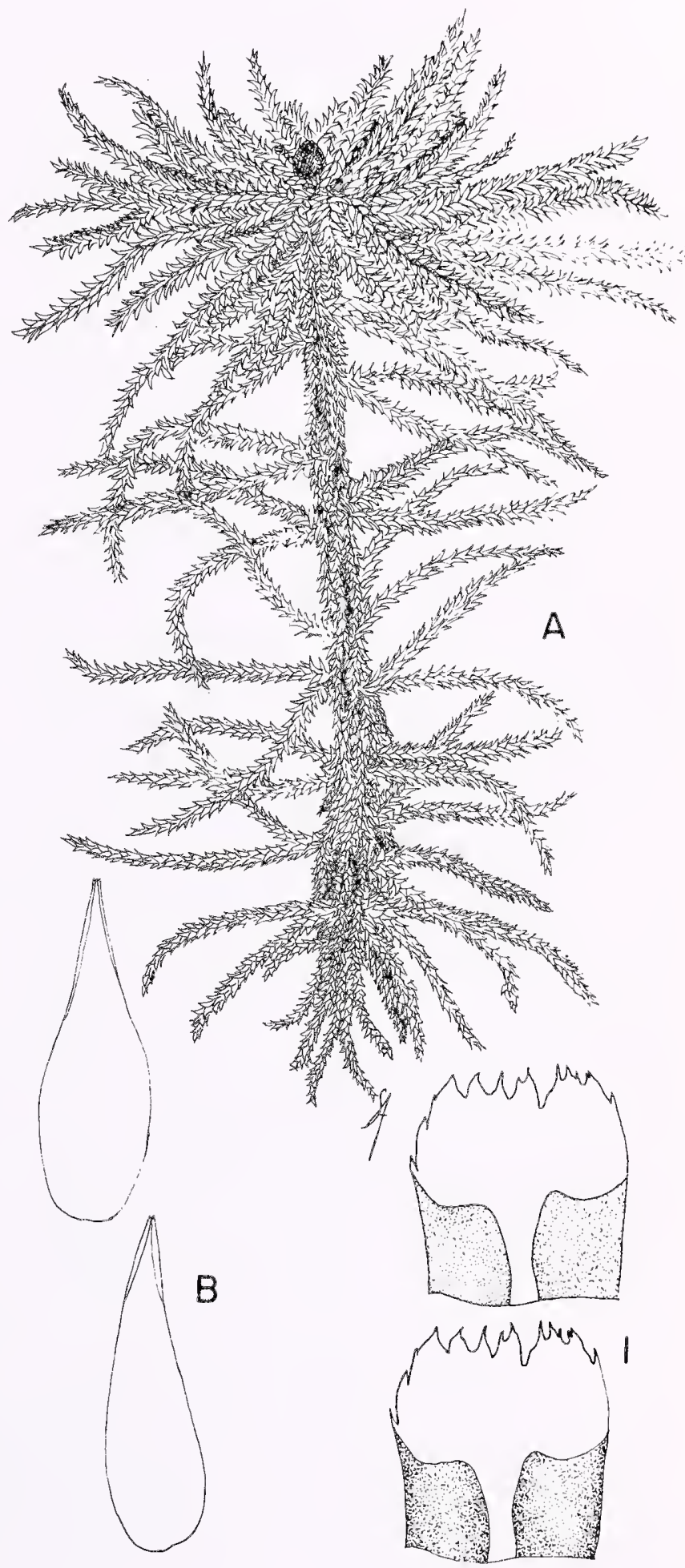


Distinguishing Characters: Due to the robust growth and the 5-ranked branch leaves, confusion is possible with $S$. pulchrum, but the large, lacerate stem leaves

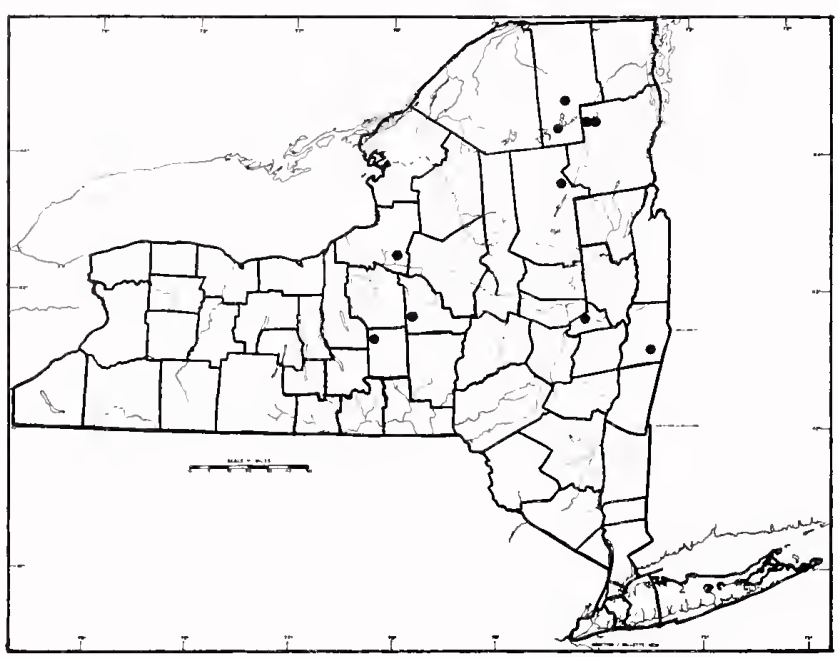

\section{Sphagnum riparium Ångstr.}

Type Description: Ångström, Öfvers. K. Svenska Vetensk-Akad. Förh. 21: 168, 1864.

Ecology: Minerotrophic. Usually growing at water level. Near poor fen margins; commonly associated with Sphagnum fimbriatum, S. girgensohnii, $S$. angustifolium and S. fallax. Also in Thuja occidentalis, Abies balsamea and Acer rubrum fens as well as floating carpets bordering lakes.

Habit: Plants moderate-sized to robust; normally stiff and upright; typically with a conspicuous terminal bud. Forming carpets.

General Distribution: Circumpolar, with continental tendencies in Europe. Also with continental tendencies in North America. In North America from the arctic south to New York, Ohio, Michigan, Wisconsin, Minnesota, Montana and Washington.

Description: Stem pale, its cortex little-differentiated; stem leaves large and triangular-lingulate, with a deep rent in the apex; hyaline cells efibrillose and often divided; branch leaves ovate-lanceolate and only rarely 5 -ranked, when dry weakly undulate and rather abruptly recurved at the apex; hyaline cells on the convex surface with 1-several small pores per cell, these often confluent and appearing as a large hole at the distal end of the cell; concave surface with large, round, pore-like wall-thinnings in the cell angles; chlorophyll cells in transverse section triangular to trapezoidal, the apex normally slightly exposed on the concave surface; pigment brown; plants green, pale yellow or rarely brown. and very dark stem of $S$. lindbergii will easily separate it from S. pulchrum and other large Cuspidata species.

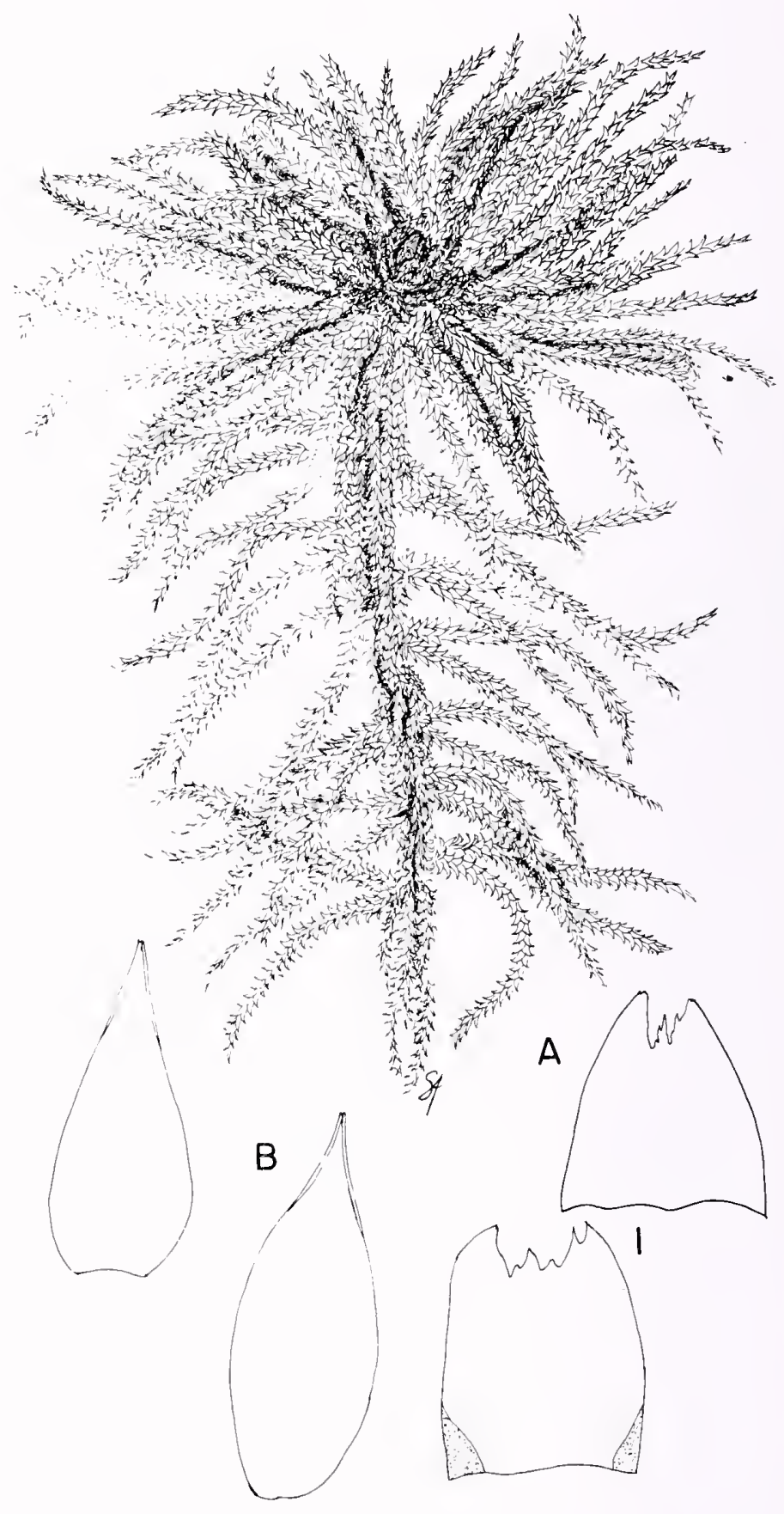


Distinguishing Characters: Sphagnum riparium is a very distinct species, often easily recognized in the field by its robust growth habit and distinct terminal bud. In $S$. lindbergii the stem leaf has its apex broad and lacerate, not tom down the middle as in S. riparium.

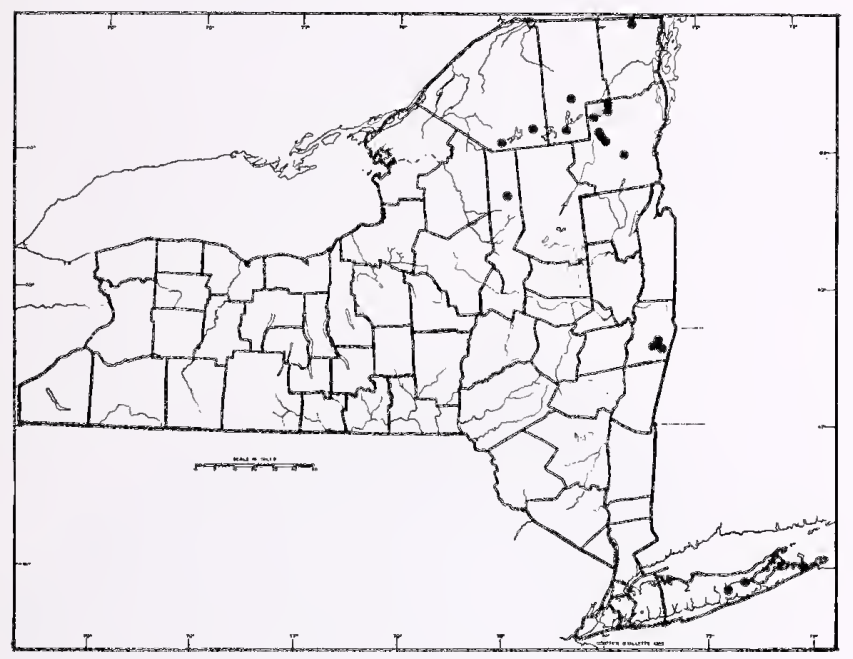

21. Sphagnum pulchrum (Braithw.) Warnst.

Type Description: Warnstorf, Bot. Cbl. 82: 42, 1900. Ecology: Weakly minerotrophic to ombrotrophic. In northern suboceanic regions a characteristic and widespread poor fen species. Near the coast also in ombrotrophic mires. Found in wet, often floating, carpets in poor fens or near the margins of bogs. In upstate New York, commonly associated sphagna include S. papillosum, S. majus, S. fallax, and S. flexuosum. Sphagnum torreyanum and S. cuspidatum are associates on Long Island.

Habit: Plants moderate-sized to large, often quite robust and densely branched. Forming \pm dense carpets.

General Distribution: Amphiatlantic and amphipacific, absent from much of continental interior. In North America from the Hudson Bay Lowlands and Newfoundland south to coastal North Carolina and inland through Pennsylvania, New York, Wisconsin and Michigan. Also in British Columbia and Alaska.

Description: Stem pale green or brown (very rarely pink-tinged); cortex 2-3 layers of enlarged and \pm thick-walled cells; stem leaves triangular to triangularlingulate, apex acute to normally apiculate; hyaline cells undivided and mostly efibrillose; branch leaves ovate to ovate-lanceolate, normally 5-ranked and often subsecund, when dry not usually recurved but sometimes undulate, apex abruptly involute to form a short distinct point; hyaline cells on the convex surface with 0 -several pores and/or pseudopores in the cell ends
Importance: In New York it is quite a minor vegetational element where it occurs, but becoming much more widespread and ecologically important in northern portions of its range (Lange 1969), especially in regions with continental climates.

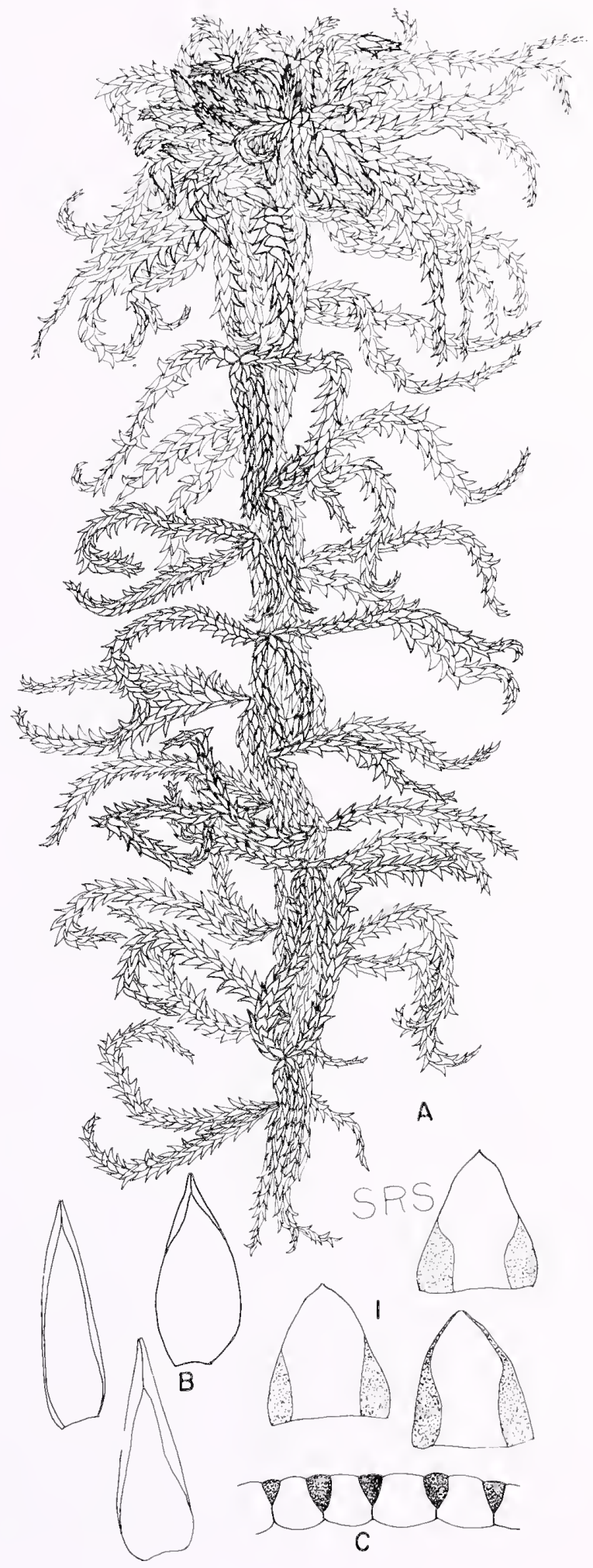


and along the commissures and on the concave surface with round pore-like wall-thinnings in the cell angles; chlorophyll cells in transverse section triangular or triangular-ovate, the apex well enclosed and often reaching only halfway to the concave surface; pigments brown and red, the red very inconspicuous; plants green, yellow-brown, golden-brown to dark brown.

Distinguishing Characters: The distinction between $S$. pulchrum and S. fallax has long troubled bryologists though in recent years nearly all have given $S$. pulchrum specific status. Well-developed S. pulchrum is easily recognizable on aspect alone by its short, thick

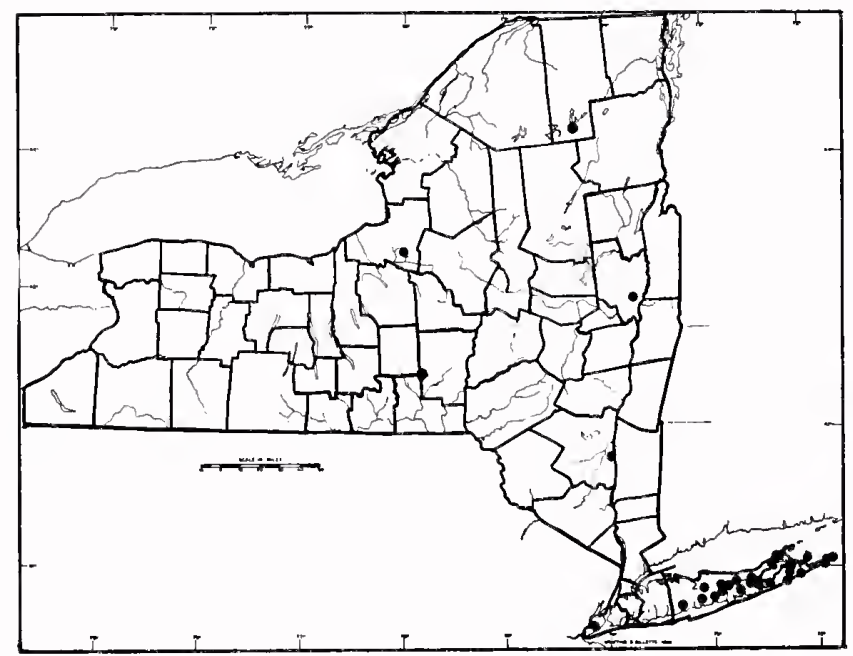

22. Sphagnum recurvum P. Beauv.

Type Description: Palisot de Beauvois, Prodr., p. 88, 1805.

Synonyms: S. pulchricoma C. Müll., S. riparioides Warnst.

Ecology: Weakly minerotrophic. Found at water level.

On Long Island found at the margins of abandoned cranberry bogs and in a wide variety of open and wooded, poor fen habitats. Frequent associates here are S. fallax, S. papillosum, S. torreyanum, S. rubellum, S. lescurii, and S. magellanicum.

Habit: Plants moderate-sized to robust, often quite lax and soft, with the aspect of a large, pale Sphagnum angustifolium. Forming open carpets.

General Distribution: Unclear due to the broad concept of $S$. recurvum employed by most authors. Probably coastal plain with an extension inland around the Great Lakes on the Western Hemisphere Atlantic coast. In North America known from Nova Scotia south to Florida, Alabama, Louisiana and Texas. Inland to Ohio, Indiana, Illinois, Missouri and Arkansas. Also in South America. branches with their broad, abruptly pointed and sharply 5-ranked leaves. Slender forms of S. pulchrum are more troublesome and are best separated from $S$. fallax by their branch leaf chlorophyll cells, well enclosed on the concave surface, and broader, more pointed branch leaves. Sphagnum torreyanum, which has a similar stem leaf shape and chlorophyll cells cross section, can be difficult to separate in some forms. However, its branch leaves are much more elongate toward the branch tips and its stem cortex more clearly differentiated than in S. pulchrum.

Importance: Rare in New York State, but in some boreal suboceanic regions an important peat former.

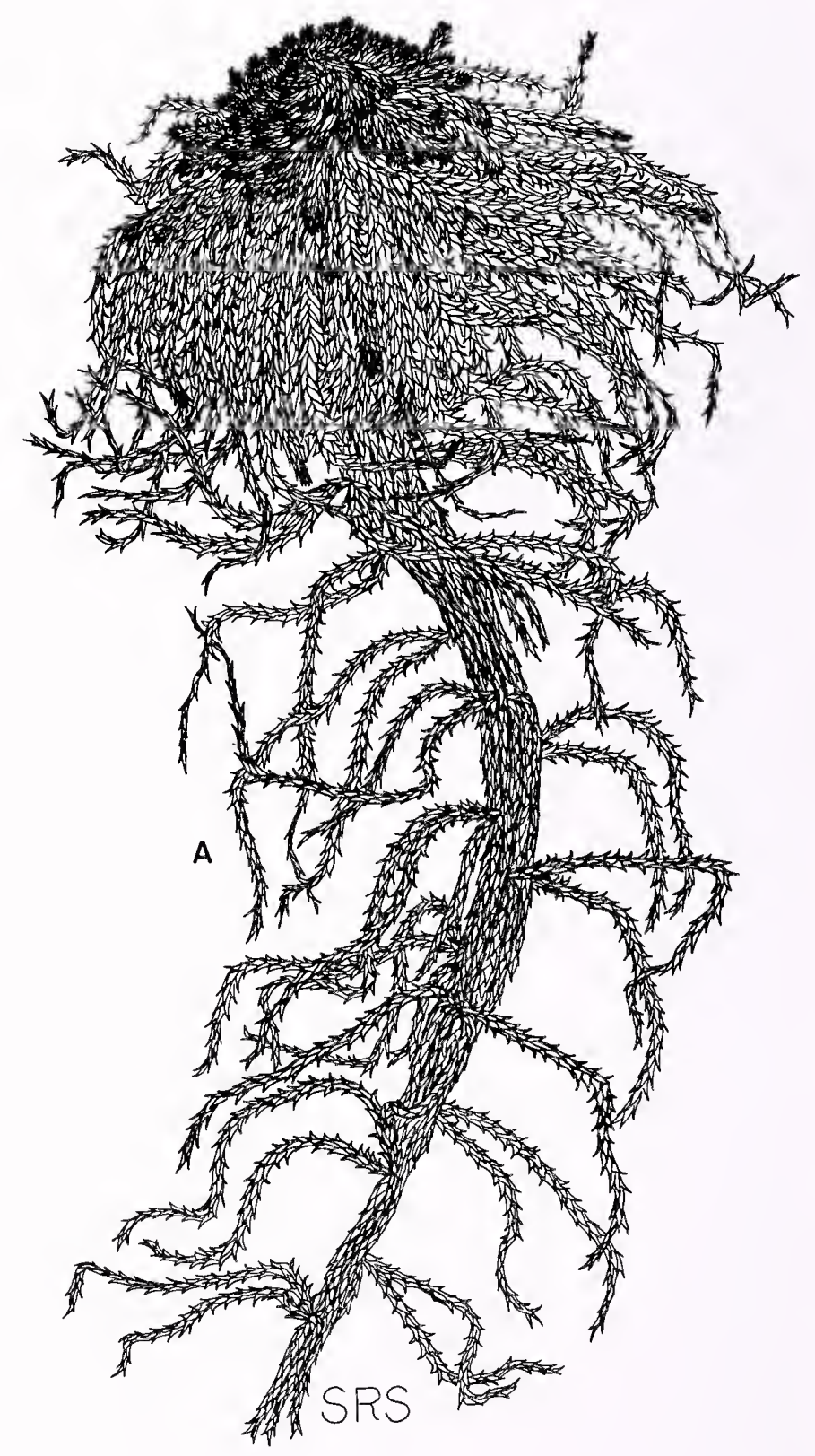


Description: Stem pale, its cortex 2-3 layers of enlarged thin-walled cells; stem leaves triangularlingulate to lingulate and typically erose to fimbriate across the narrowly to broadly obtuse apex; hyaline cells normally undivided and efibrillose; branch leaves long and narrowly ovate-lanceolate, normally 5-ranked, when dry, undulate and recurved; hyaline cells on the convex surface typically with 1 pore at the distal end of each cell with additional pores (if present) at the proximal end and sides; concave surface with small to moderate-sized round pore-like wall-thinnings in the cell angles, these occasionally lacking; chlorophyll cells in transverse section triangular, the apex well enclosed or barely reaching the concave surface; hanging branches strong, their leaves similar to those on spreading branches; pigment brown; plants green, pale yellow or brown-tinged.

Distinguishing Characters: In its characteristic form $S$. recurvum is a large and beautiful plant easily recognized in the field; however, certain forms may be confused with the other species in the complex. Sphagnum fallax is the only similar species found in New York with which significant range overlap occurs. Normally, the apiculate stem leaves will easily separate this species from $S$. recurvum. Some forms of $S$. recurvum have poorly developed stem leaves in which the apex may be drawn together and \pm involute. On such plants, however, typical leaves will usually also be evident. The branch leaf hyaline cells in $S$. recurvum are longer and narrower and their concave surface wall-thinnings smaller than in S. fallax. S. recurvum also has narrower branch leaves, a more distinct stem cortex and the chlorophyll cells are more enclosed on the concave branch leaf surface. These last two characters are of limited usefulness as $S$. fallax in coastal habitats approaches $S$. recurvum in these regards. In mixed communities, which are fairly common on Long Island, $S$. recurvum is larger, softer and paler than $S$. fallax. Sphagnum flexuosum has a similar stem leaf but also has considerably shorter and broader branch leaves that are only rarely 5-ranked, a poorly defined stem cortex, and chlorophyll cells normally exposed on the concave surface. Sphagnum angustifolium is a much smaller, slenderer plant with an undifferentiated stem cortex, smaller stem leaves with an entire apex and a stem that is frequently pale pink.

Importance: A dominant plant in many coastal mires from Massachusetts south through Georgia.

Note: The binomial $S$. recurvum has been used in several senses. Andrews (1913) used it in a collective sense to include $S$. recurvum sensu stricto, S. fallax, S. angustifolium, and S. flexuosum. Used in this broad sense, S. recurvum has often been applied to European material. With a widening recognition of $S$. fal-
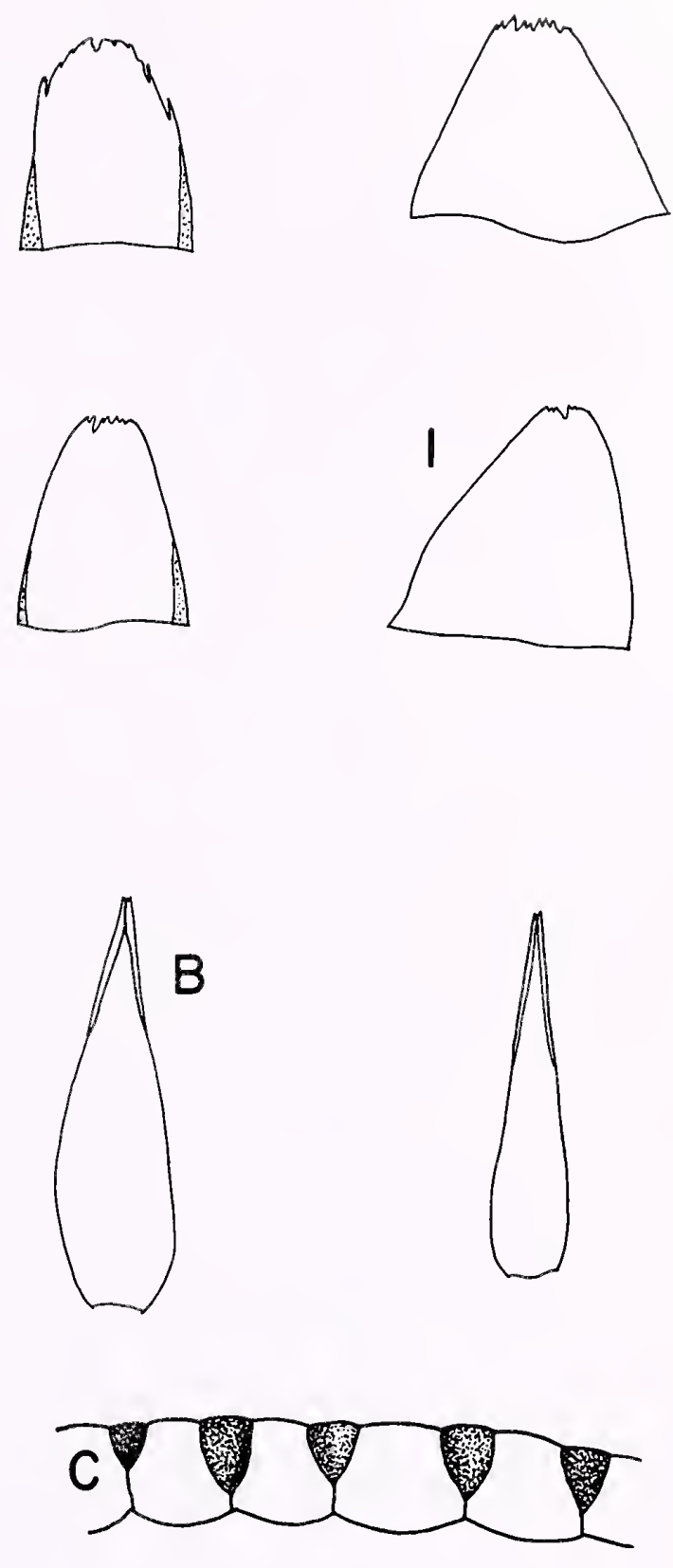

lax, S. angustifolium and S. flexuosum as distinct taxa, it has become clear that the name $S$. recurvum, based on material collected from the coastal plain of North Carolina, probably does not apply to any European taxa (Isoviita, 1966). Resolution of the problem has come through typification of $S$. recurvum (Smith, 1977). Great care must be used, however, in interpreting the use of the name $S$. recurvum by other authors, since it is still widely used in the broad sense (see, for example, Crum, 1976). 


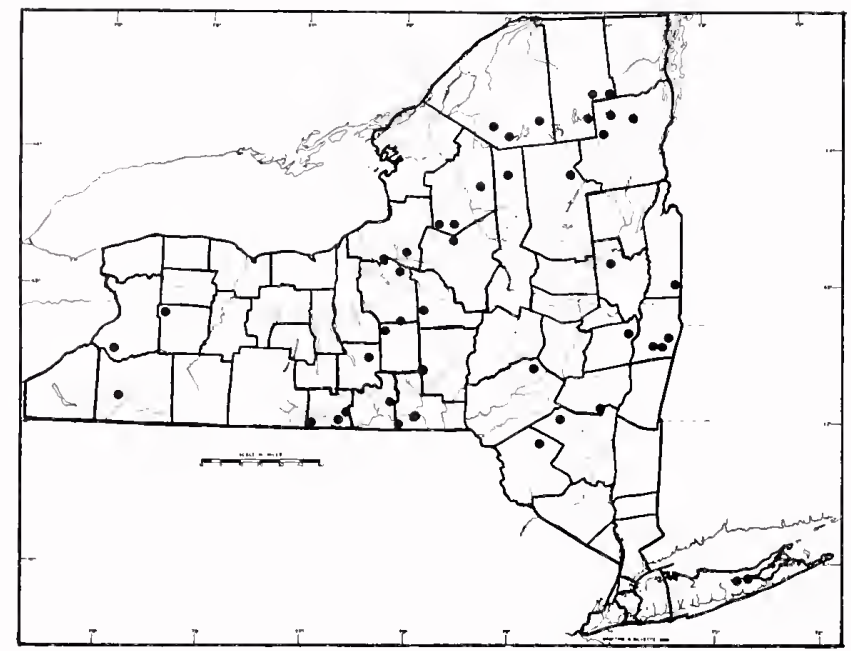

23. Sphagnum flexuosum Dozy \& Molk.

Type Description: Dozy \& Molkenboer, Prodr. Fl. Bat., 11, 1, p. 76, 106, tab. 111, 1851.

Synonym: S. amblyphyllum (Russow) Zickendrath

Ecology: Minerotrophic. Growing at or near water level, near the margin of open poor fens, among heath shrubs at pond margins and occasionally in mire-wide poor to medium fen vegetation. Common associated species include Sphagnum angustifolium, S. majus, S. subsecundum and S. teres. Also in poor, wooded, (most coniferous) fens, often with $S$. centrale and $S$. girgensohnii. Seldom very abundant.

Habit: Plants small- to moderate-sized, often somewhat soft and spreading, forming carpets and occasionally low hummocks.

General Distribution: Amphiatlantic. Details of distribution unclear due to frequent inclusion in $S$. recurvum sensu lato in eastern North America from the subarctic (rare ?) south to at least West Virginia and inland around the Great Lakes to Minnesota.

Description: Stem pale, its cortex undifferentiated or slightly differentiated; stem leaves triangular-lingulate to lingulate; apex narrowly to broadly obtuse and usually erose; hyaline cells undivided and only rarely fibrillose; branch leaves ovate to broadly ovatelanceolate, seldom 5-ranked, when dry undulate and recurved; hyaline cells on the convex surface typically with 1-2 (rarely more) pores at the cell ends and often toward the leaf apex with \pm numerous pseudopores along the commissures and on the concave surface with large round pore-like wall-thinnings in the cell angles; chlorophyll cells in transverse section triangular, typically slightly exposed on the concave surface; hanging branches slender to strong and tightly covering the stem, their leaves often with large holes at the upper ends of the hyaline cells on the convex sur-

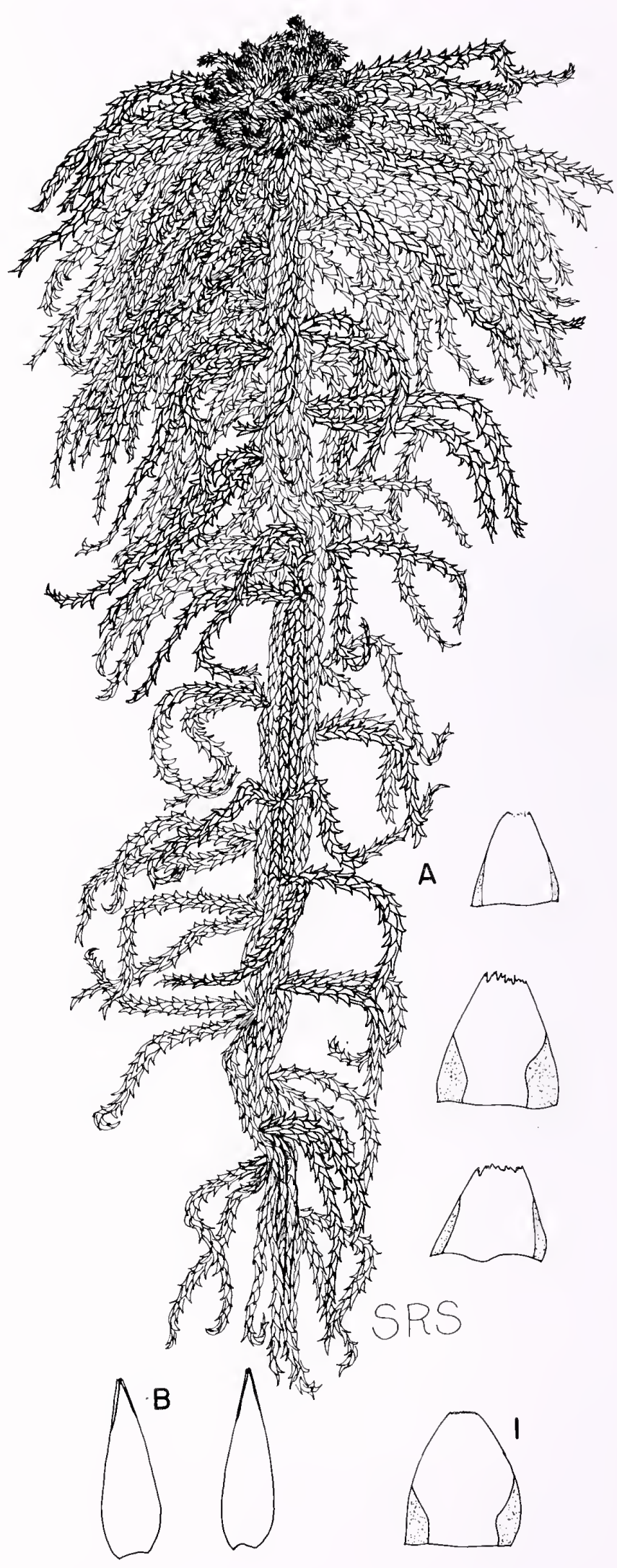


face; pigments brown and red (the red very inconspicuous); plants typically pale yellowish-green, yellowishbrown, or grayish-brown, rarely a fuscous-brown, the branch bases occasionally red-tinged.

Distinguishing Characters: Sphagnum flexuosum can often be recognized in the field by its pale coloration and peculiar, small knot-like capitulum that perhaps

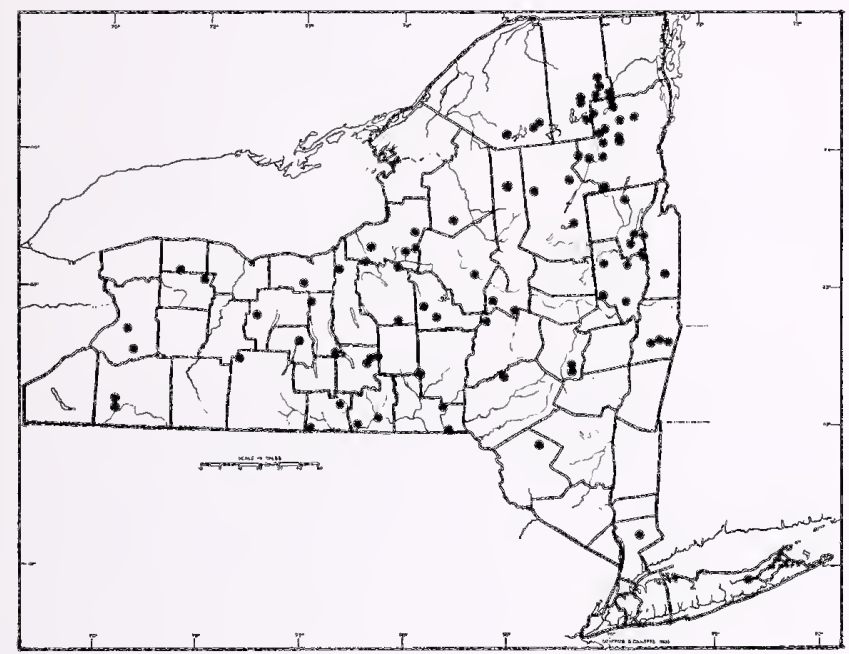

24. Sphagnum angustifolium (Russow) C. Jens.

Type Description: C. Jensen in Tolf, Bih. K. Sv. Vetensk-Akad. Handl. afd. III, 16:9, p. 9, 48, 1891.

Synonyms: S. recurvum var, tenue Klinggr., S. parvifolium (Warnst.) Warnst.

Ecology: Ombrotrophic to moderately minerotrophic. Occurring at or somewhat above water level. Found in a wide variety of very poor to medium-fen habitats. Ombrotrophic at the margins of mires and in open, mire-wide, poor fen vegetation, frequently associated with Sphagnum fallax. Also in somewhat. richer fens, there often with S. flexuosum. Common in poor to medium-wooded coniferous fens associated with $S$. girgensohnii, S. russowii, S. teres, S. warnstorfii and $S$. centrale. In the Adirondack Mts., of New York abundant over exposed wet siliceous slopes.

Habit: Plants small to moderate-sized, usually slender. Forming open to dense carpets and low hummocks.

General Distribution: Circumpolar, with slightly continental tendencies (Isoviita, 1966). In North America from the arctic south at least to West Virginia, Ohio, Indiana, Illinois, Iowa, Minnesota, North Dakota, Colorado, Montana, Utah, Idaho and California. South of New York it is restricted to higher elevations in the mountains. most resembles a tiny, but loose ball of yarn. (See also under S. fallax, and S. angustifolium.)

Importance: Though widespread, S. flexuosum is usually much less important ecologically than the closely related $S$. angustifolium and $S$. fallax, with which it often occurs.

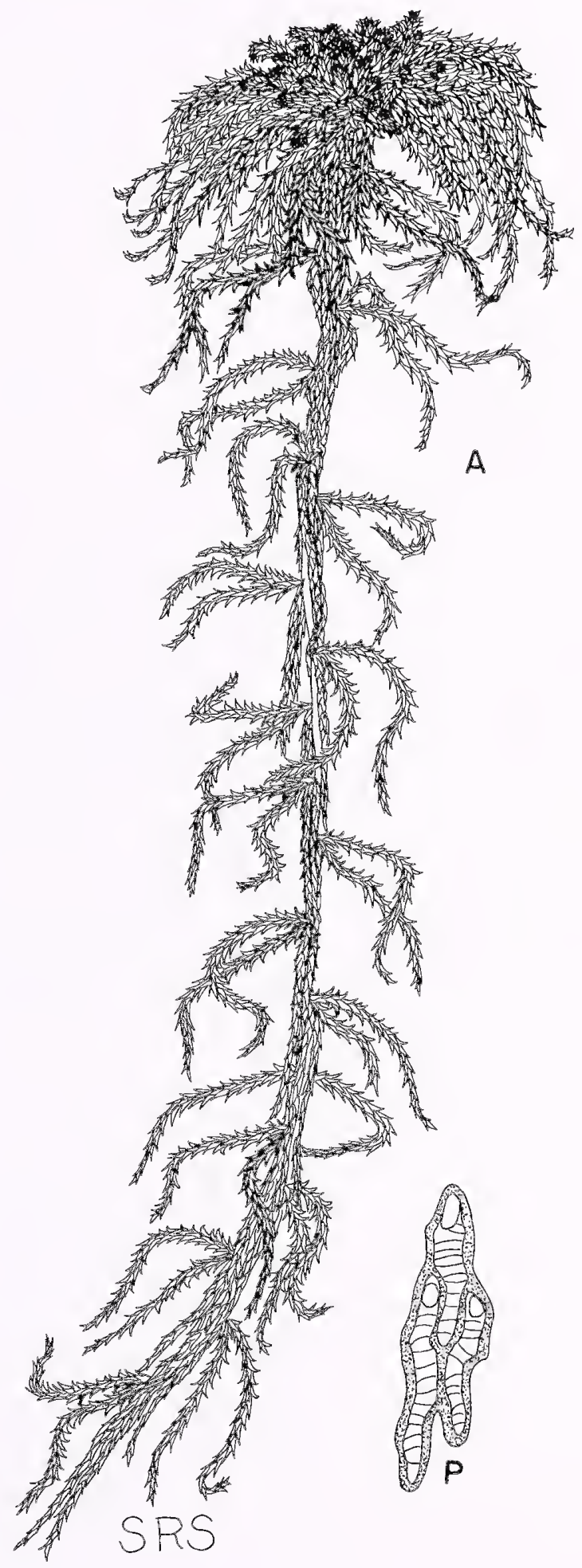


Description: Stem pale and often distinctly pinkish, its cortex undifferentiated; stem leaves small and broadly triangular; apex acute (rarely) grading to broadly rounded and \pm weakly denticulate; hyaline cells undivided and usually efibrillose; branch leaves narrowly ovate-lanceolate and nearly always 5-ranked, when dry undulate and recurved (in more xerophytic forms the undulations reduced or absent); hyaline cells on the convex surface with 1 -several pores at the cell ends and near the commissures, often also with numerous pseudopores along the commissures near the leaf apex and on the concave surface with large, round, porelike wall-thinnings in the cell angles; chlorophyll cells triangular in transverse section, apex typically just enclosed within the concave surface; hanging branches often (but not always) thread-like, their leaves normally with large holes at the distal ends of the hyaline cells on the convex surface; pigments brown and red (the red in the stem and branch bases only); plants green, yellowish-brown or a dark slightly reddishbrown, branch bases typically red.

Distinguishing Characters: In its typical state, $S$. angustifolium is recognizable by its slender form, thin branches, small narrow branch leaves, and small, broadly triangular stem leaves. When present, the pink stem coloration is also useful, as the similar $S$. fallax and S. flexuosum lack this character.

Sphagnum angustifolium frequently grows intermixed with $S$. fallax and can often be easily separated by its darker color and pink stems. In similar mixed collections, $S$. flexuosum is distinguishable from $S$. angustifolium by its knot-like capitula and paler coloration. When all three are found together, S. flexuosum is the palest and S. angustifolium the darkest as well as the only one with pink stems.

Infraspecific Variation: Because of the frequent misapplication of several of its synonyms, S. angustifolium
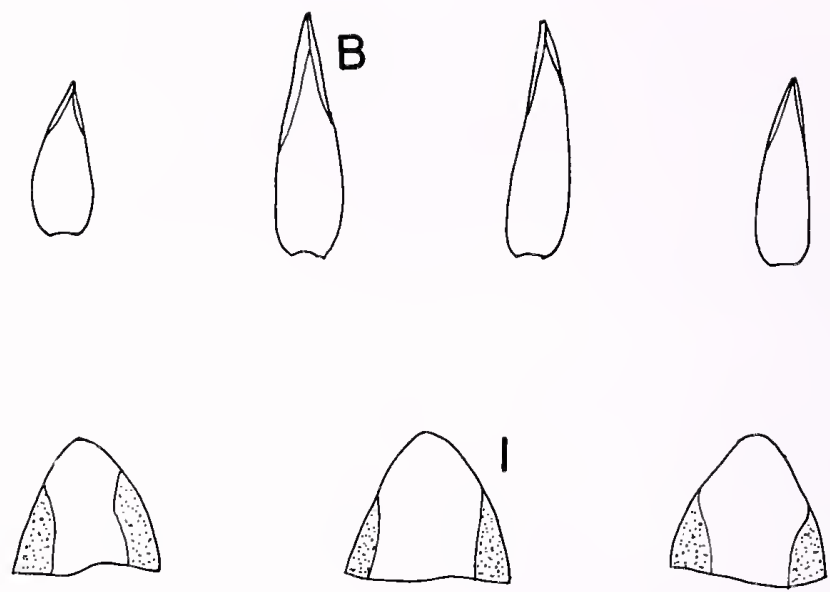

has been a poorly understood species. For example, Sphagnum parvifolium has often been used to designate a $S$. wulfianum-like, xerophytic form with a thickly branched capitula and very long, slender, hanging branches. Though such forms of $S$. angustifolium are common, S. fallax also develops similar modifications. Another infraspecific variation, often recognized as Sphagnum recurvum var. tenue, is a small form of $S$. recurvum s.1., in which the branch leaves, due to their reduced size, have no undulations and in some cases are not even recurved. Such a "variety" is, unfortunately, purely artificial and includes small forms of S. angustifolium, S. fallax, S. flexuosum and S. recurvum. See also under S. fallax.

Importance: Along with $S$. fallax, a dominant carpetforming species in ombrotrophic and weakly minerotrophic mires of boreal suboceanic distribution. Also important ecologically in continental areas, where it is often associated with $S$. riparium. 


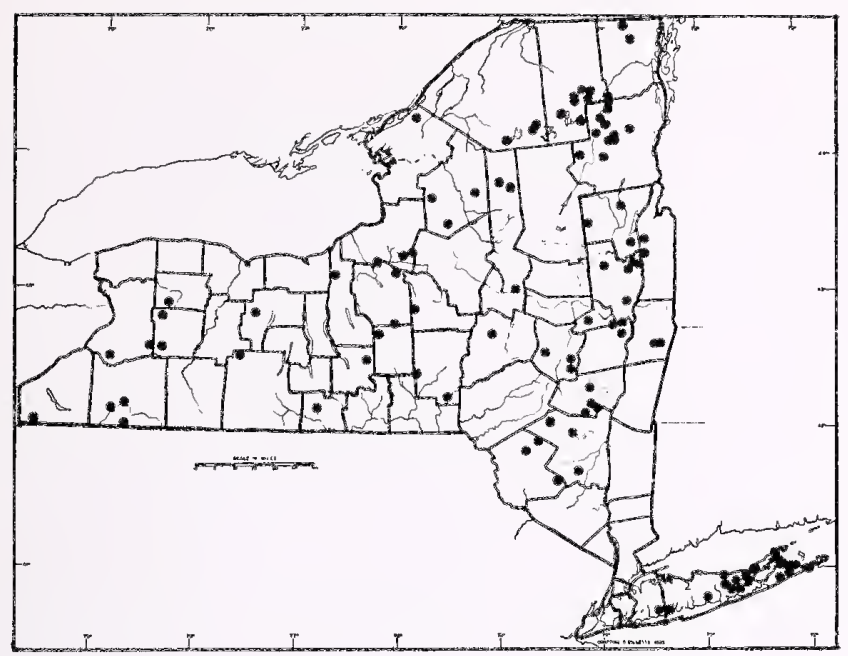

25. Sphagnum fallax (Klinggr.) Klinggr.

Type Description: Klinggraff, Vers. Topogr. Fl. Prov. Westpr., p. 128, 1880.

Synonyms: S. mucronatum (Russow) Zickendrath, S. apiculatum $H$. Lindb., $S$. recurvum auct., non $P$. Beauv., S. intermedium auct., non Hoffm.

Ecology: Ombrotrophic to weakly minerotrophic. Growing at or near water level. A characteristic and widespread poor fen species found in a wide variety of forested and open mires with little or no mineral influences. Common associated species are Sphagnum angustifolium, S. rubellum, S. nemoreum, S. girgensohnii, S. russowii and S. magellanicum. On Long Island, S. recurvum is an important associate. In the Adirondack Mts. of New York $S$. fallax is also common over very wet and exposed siliceous rocky slopes. Often a dominant member of the plant communities in which it is found.

Habit: Plants moderate-sized to fairly large; slender to \pm robust and thickly branched. Forming open to \pm dense carpets.

General Distribution: Amphiatlantic and amphipacific, absent from much of continental interior. North American distribution unclear due to the collective status often given Sphagnum recurvum. In eastern North America from the arctic (probably rare) south to North Carolina and inland around the Great Lakes to Minnesota. In western North America from Alaska south to Washington.

Description: Stem pale, its cortex undifferentiated or sometimes 2 layers of \pm enlarged and thin-walled cells; stem leaves triangular to triangular-ovate, apex typically apiculate, infrequently acute; hyaline cells undivided and normally efibrillose; branch leaves ovate-lanceolate and \pm 5-ranked, when dry undulate and recurved; hyaline cells on the convex surface with

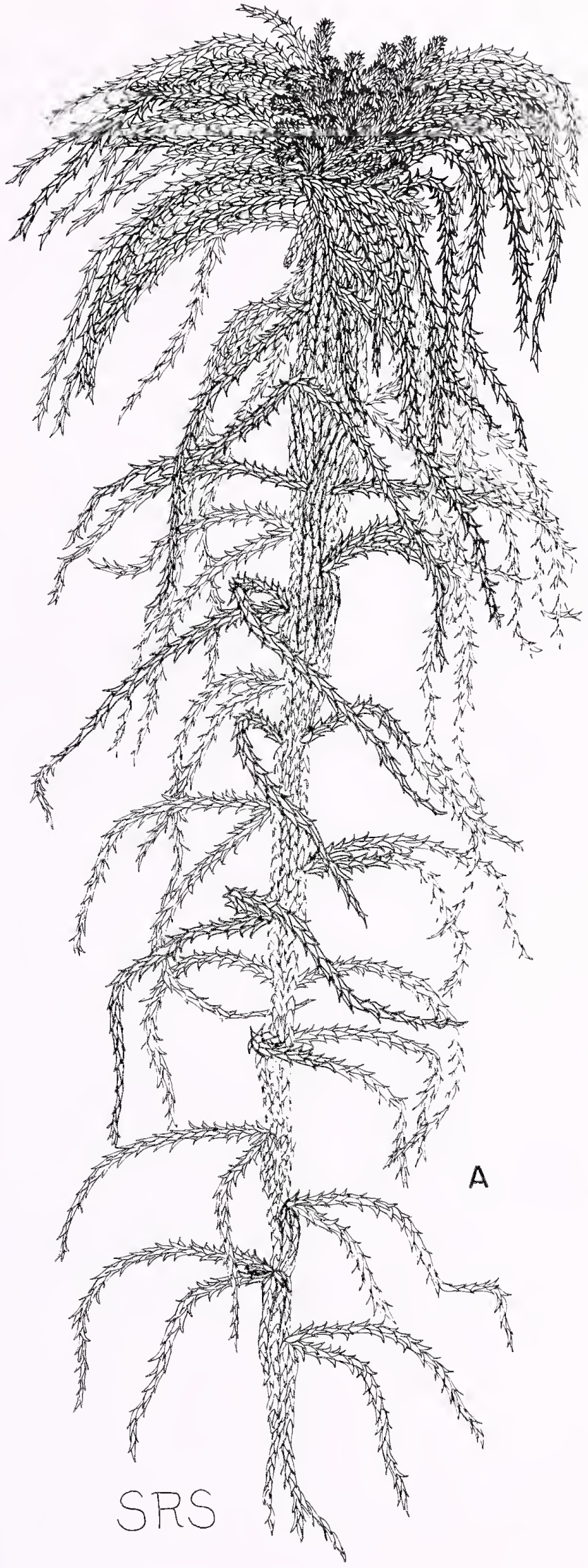


1-2 (rarely more) pores at the cell ends, and sometimes with \pm numerous pseudopores along the commissures toward the leaf apex and on the concave surface with the large, round, pore-like wall-thinnings in the cell angles; chlorophyll cells in transverse section triangular and slightly enclosed to slightly exposed on the concave surface; hanging branches strong, their leaves like those on the spreading branches; pigments brown and red (the red very inconspicuous); plants green, yellowish-brown, or brown, often tinged with dark brown, the branch bases occasionally red-tinged. Distinguishing Characters: See under Sphagnum pulchrum, S. recurvum, S. angustifolium and S. flexuosum.

Infraspecific Variation: Some common aquatic modifications of $S$. fallax can have an acute rather than mucronate stem leaf apex and may be mistaken for $S$. angustifolium if this character is relied upon. Sphagnum angustifolium is, however, less hydrophytic than S. fallax and very rarely aquatic. Sphagnum fallax occasionally is found submerged and such forms can resemble $S$. cuspidatum. Forms of this type, however, differ in their relatively undifferentiated stem cortex, stouter aspect, and branch leaves much less attentuate at the branch tips, as well as not falcatesecund.

Importance: Sphagnum fallax is usually a dominant species in ombrotrophic to weakly minerotrophic mires of boreal oceanic and suboceanic regions.

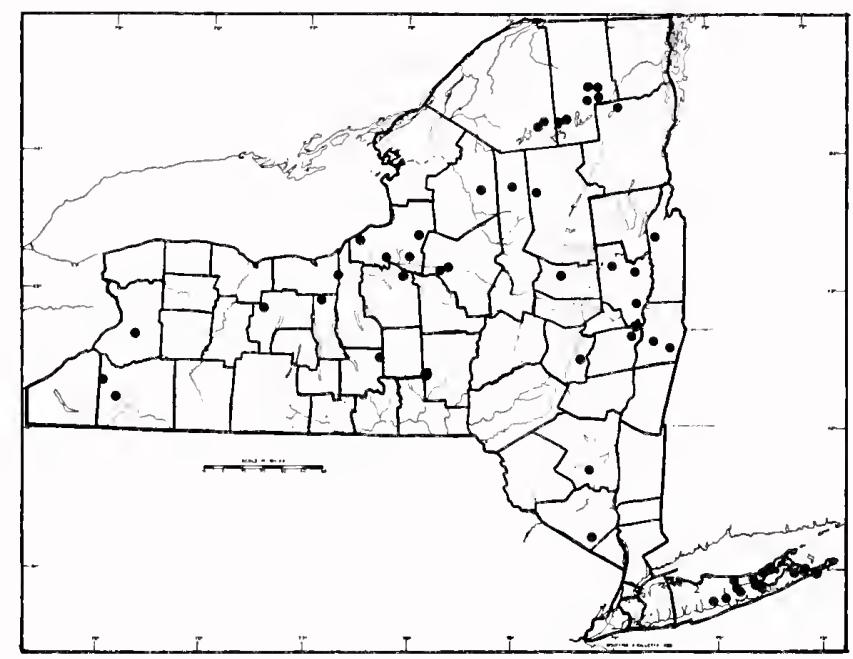

26. Sphagnum cuspidatum Hoffm.

Type Description: Ehrhart ex Hoffman, Deuts. Fl. 2:22, 1795--1796.

Synonyms: S. laxifolium C. Müll, S. virginianum Warnst., S. faxonii Warnst.

Ecology: Ombrotrophic to weakly minerotrophic. Growing submerged or at water level in shallow pools or depressions in floating or firm bog mats,
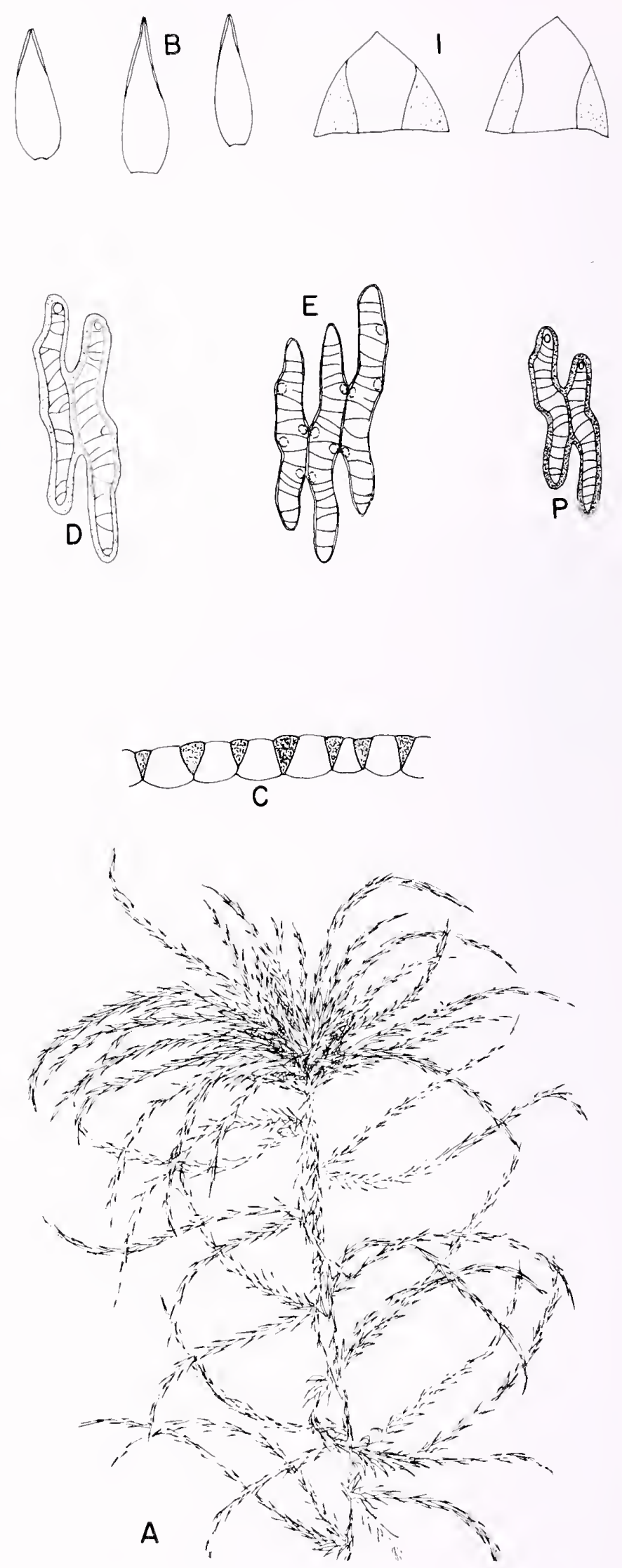
commonly mixed with $S$. majus and associated with S. papillosum, S. rubellum, S. fallax, S. nemoreum, and $S$. fuscum. On the coastal plain also found in shallow, sandy-bottomed, oligotrophic ponds with $S$. torreyanum and S. lescurii.

Habit: Plants \pm moderate-sized; varying from quite plumose in aquatic forms to soft and somewhat compact in emergent forms. Occurring as scattered floating plants or \pm open carpets.

General Distribution: Amphiatlantic and possibly west pacific. In North America from the Hudson Bay Lowlands south to Georgia and inland around the Great Lakes to Michigan, Wisconsin and Minnesota. Also known from southern Illinois, southeastern Kansas and Louisiana. Absent in western North America.

Description: Stem pale, its 2--3 layers of enlarged, thin-walled cells; stem leaves triangular-ovate, apex, acute to apiculate; hyaline cells rarely divided and often fibrillose toward the leaf apex; branch leaves ovate-lanceolate to lanceolate and sometimes 5-ranked, very elongate and falcate-secund toward the branch tips, when dry sometimes weakly undulate and/or weakly recurved; apex involute; hyaline cells on the convex surface with 0 -several pores at the cell ends and along the commissures and on the concave surface with round to elliptic pore-like wall-thinnings in the cell angles, these indistinct (or very rarely lacking) in aquatic forms; chlorophyll cells in transverse section triangular to trapezoidal, narrowly to broadly exposed on the concave surface; pigments brown and red (the red inconspicuous); plants green or yellowish, sometimes tinged with dark brown, the branch bases sometimes red, and the capitula often with a reddish tinge, this especially visible when the head branches are parted in emergent forms.

Distinguishing Characters: See under Sphagnum fallax, S. torreyanum, S. majus and S. lescurii.

Infraspecific Variation: Occasional forms of S. cuspidatum wiil develop weak serrations in the distal portion of the branch leaf margin. Such forms can be separated from Sphagnum trinitense on other characters including the undifferentiated stem cortex and stem leaf hyaline cell divisions of S. trinitense.
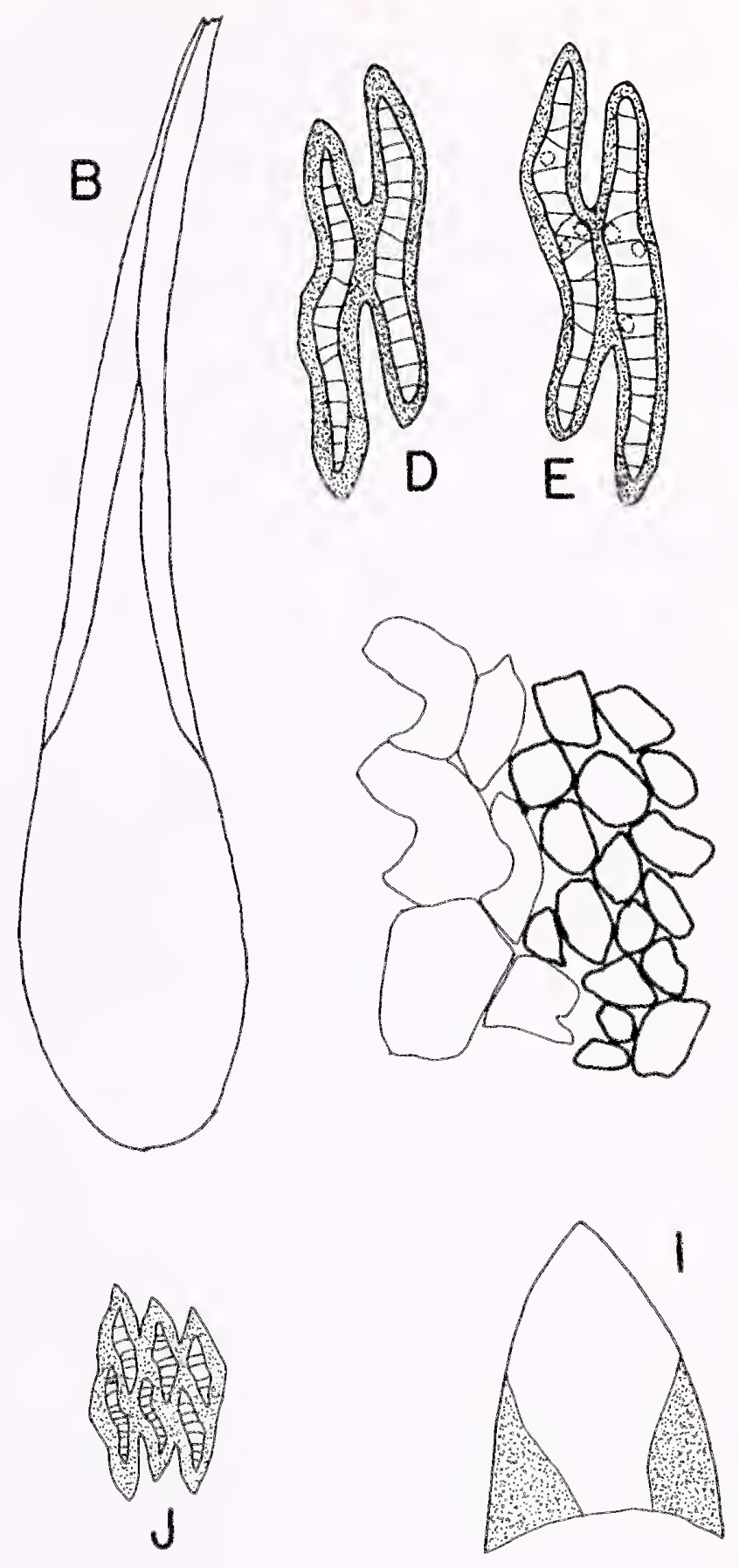


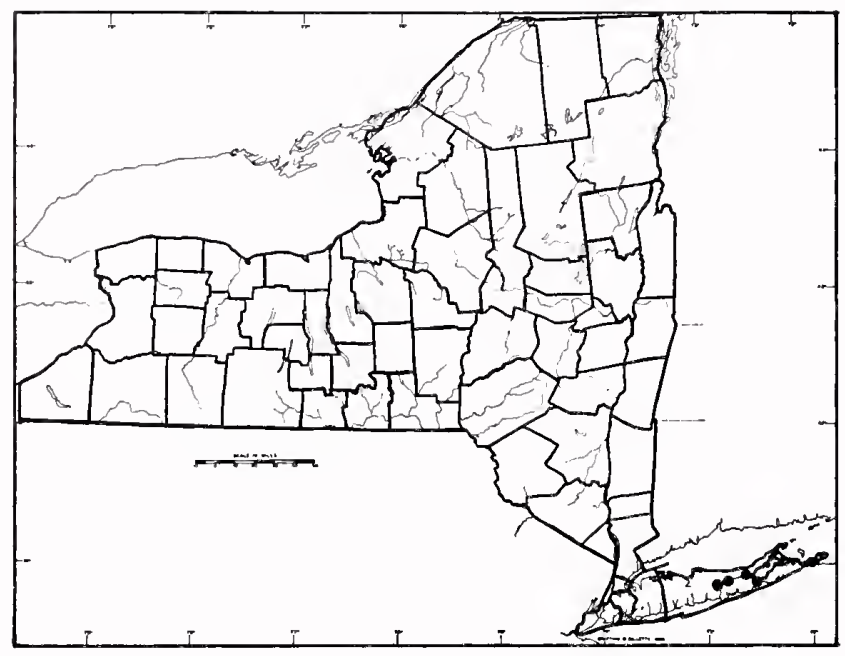

27. Sphagnum trinitense C. Müll.

Type Description: C. Müller, Syn. musc. 1, p. 102, 1848-1849.

Synonyms: S. serratum Aust., S. cuspidatum var. serrulatum auct., non $S$. laxifolium var. serrulatum Schlieph.

Ecology: Weakly minerotrophic, aquatic. Found submerged or stranded in shallow ponds, ditches, marshes, and streams. Common associates include Sphagnum cuspidatum, S. torreyanum, S. macrophyllum and S. lescurii.

Habit: Plants small to medium-sized; often submerged and plumose. Occurring as scattered plants and in \pm dense stands.

General Distribution: A Western Hemisphere Atlantic coastal plain endemic. In North America near the coast from Massachusetts south to Florida and west to Louisiana. Up the Mississippi River drainage to southeastern Kansas and southern Illinois. Also in the West Indies and South America.

Description: Stem pale, its cortex undifferentiated or nearly so; stem leaves triangular-ovate, apex acute to narrowly obtuse; hyaline cells often fibrillose and frequently 1-divided; branch leaves varying from ovatelanceolate at the branch base to very long lanceolatelinear at the branch tips, lax and not 5-ranked, when dry the longer leaves \pm undulate and twisted but not recurved, margin serrulate; hyaline cells on the convex surface with 0 -several small pores at the cell ends and near the commissures and on the concave surface with large, round, pore-like wall-thinnings in the cell angles (these frequently indistinct or lacking); chlorophyll cells in transverse section trapezoidal and quite broadly exposed on the concave surface; pigment brown; plants green to pale yellow.
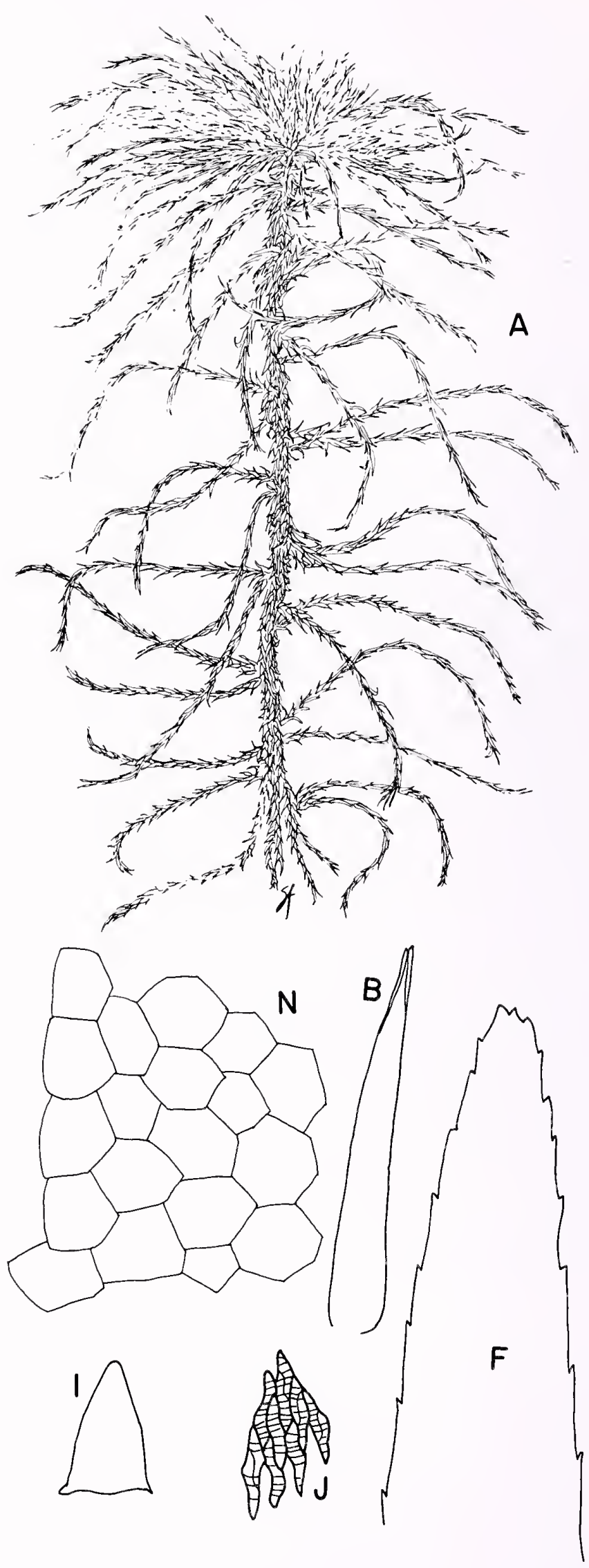
Distinguishing Characters: Sphagnum trinitense can often be field separated from $S$. cuspidatum, especially in mixed collections, by its relatively larger and more

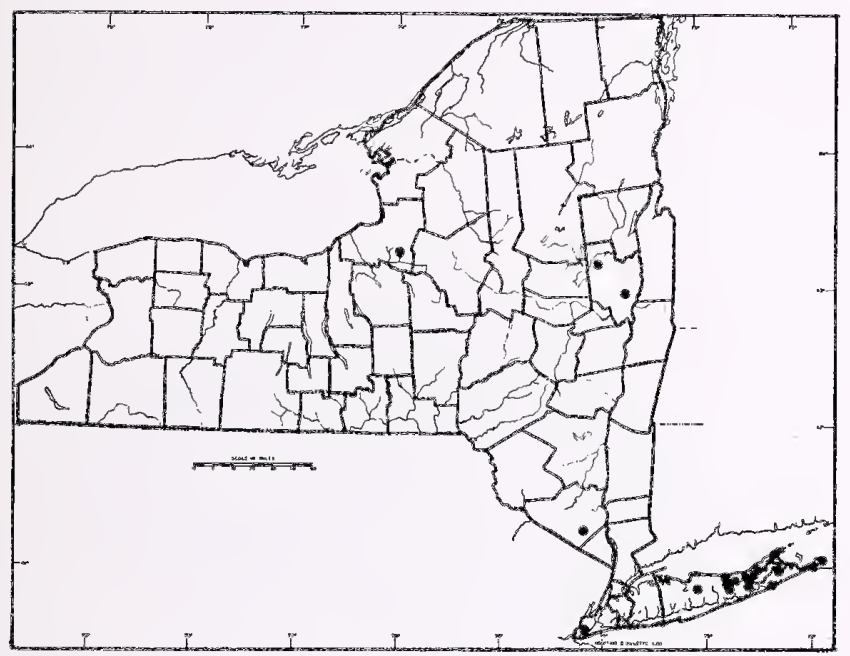

28. Sphagnum torreyanum Sull.

Type Description: Sullivant, Mem. Amer. Acad. Arts Sci., new ser. 4:174, 1849.

Synonyms: S. cuspidatum var. torreyi Braithw., S. kearneyi Warnst.

Ecology: Weakly minerotrophic, aquatic. Usually submerged or stranded and occurring in shallow oligotrophic ponds, in floating Sphagnum mats of poor fen character and along acid, weakly mineralized streams. Often mixed with S. cuspidatum, S. macrophyllum and S. lescurii.

Habit: Plants large; varying from slender and plumose in some aquatic forms to stiff, robust, and plush in emergent or stranded forms. Occurring as scattered plants, submerged stands or open carpets.

General Distribution: A North American Atlantic coastal plain endemic with scattered mountain outliers, near the coast from New Brunswick and Nova Scotia south to North Carolina.

Description: Stem pale, its cortex of 2-3 layers of enlarged thin-walled cells; stem leaves triangularlingulate, apex obtuse, acute, or rarely apiculate; hyaline cells often 1-divided and rarely fibrillose; branch leaves ovate-lanceolate to lanceolate-linear, flat or more frequently long involute to the apex, lax, 5ranked and \pm spreading, very elongate and \pm falcatesecund toward the branch tips, when dry often undulate (not undulate in stiff forms); hyaline cells on the convex surface with 0 -several pores at the cell ends and near the commissures and on the concave surface with round pore-like wall-thinnings in the cell angles, these sometimes indistinct or lacking; chlorophyll cells in transverse section typically well enclosed on the concave stem leaves as well as the tendency of its branch leaves to be quite terete, strongly resembling the tip of a narrow paint brush.

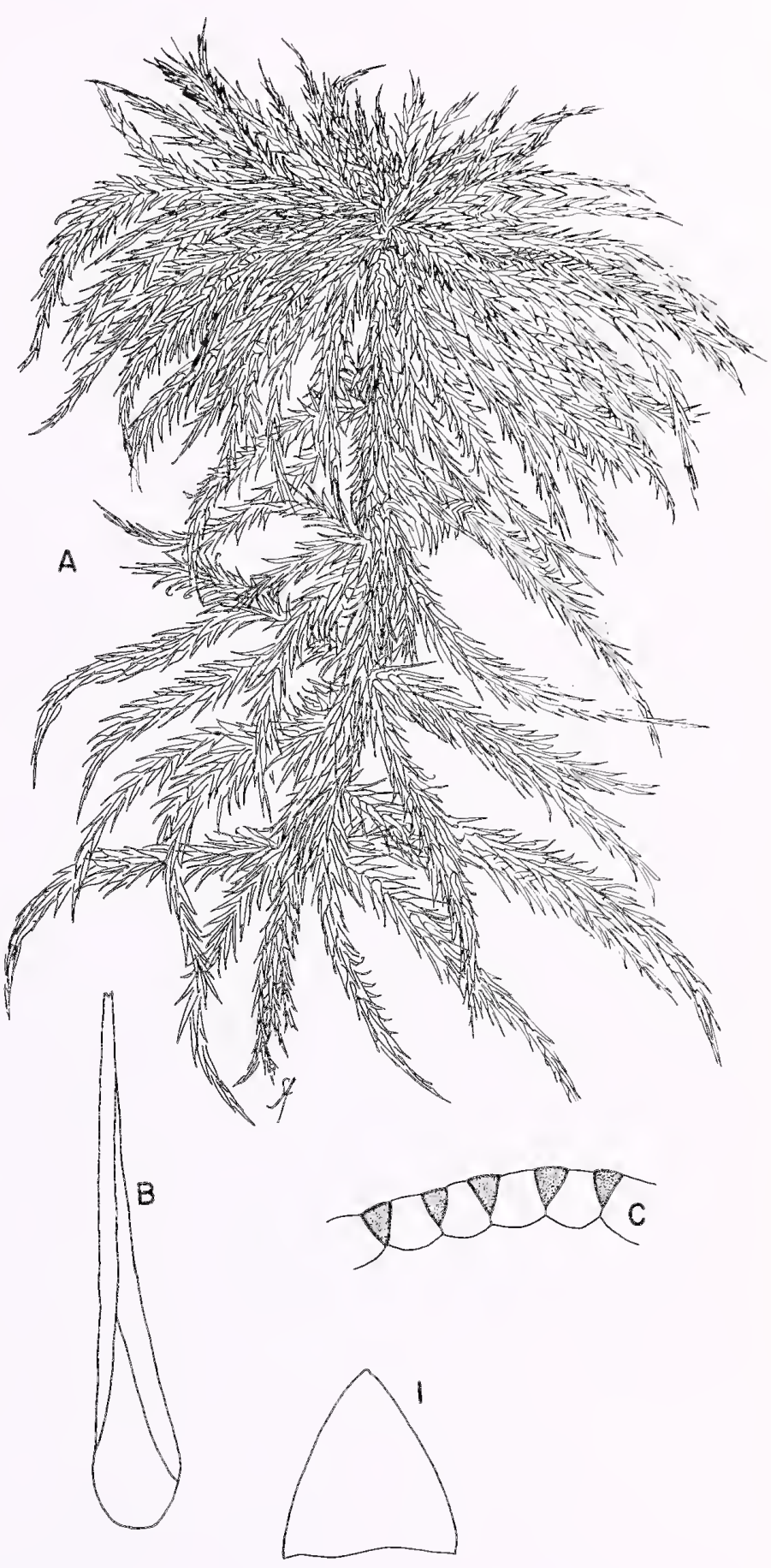


concave surface; pigments brown and red (the red very inconspicuous); plants green, yellowish-brown, or dark brown and in some pale forms the branch bases and/or stems red-tinged.

Distinguishing Characters: Sphagnum torreyanum is a large and often beautiful species usually easily identifiable even in the field. Sphagnum cuspidatum has branch leaves also greatly elongated at the branch tips, but is considerably less robust and is normally easily

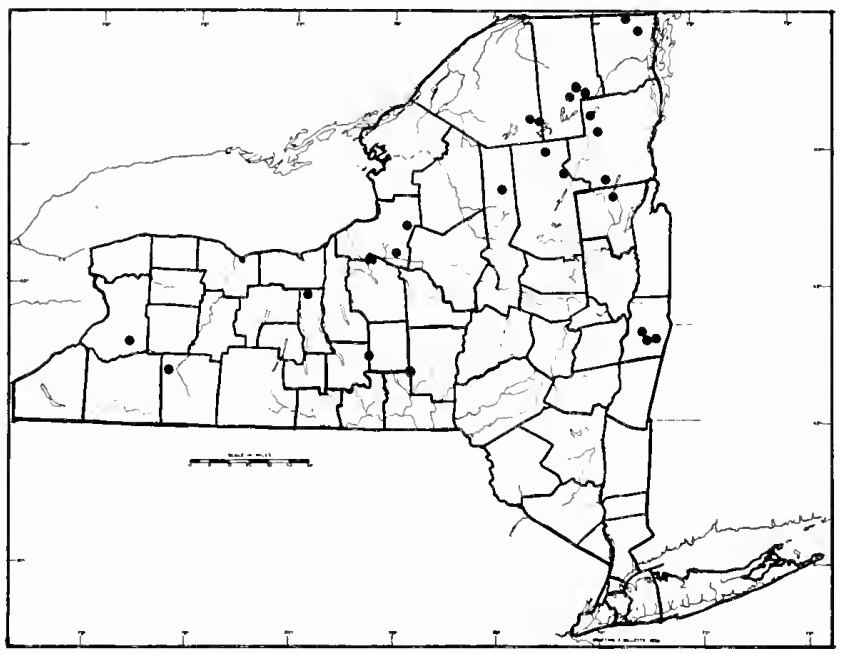

29. Sphagnum majus (Russow) C. Jens.

Type Description: C. Jensen, Dansk. Sphag., p. 106, 1890.

Synonym: S. dusenii Warnst.

Ecology: Weakly minerotrophic. Aquatic or near water level in wet depressions. In poor fens, often mixed with Sphagnum cuspidatum. Also in slightly more minerotrophic habitats. Often near the margins of poor fens, where it is associated with such species as S. flexuosum, S. pulchrum, S. papillosum, S. angustifolium and $S$. subsecundum. A light-demanding species, not found in forested mires.

Habit: Plants moderate-sized to large, forming submerged stands or emergent carpets.

General Distribution: Circumpolar, widespread in eastern North America from the arctic south to Massachusetts, Pennsylvania, Michigan, Wisconsin and Minnesota. Less common in western North America, but known from Alaska to British Columbia and Alberta.

Description: Stem pale, its cortex of 2-3 layers of enlarged and moderately thin-walled cells; stem leaves triangular-lingulate; apex acute to obtuse; hyaline cells undivided and often fibrillose near the leaf apex; branch leaves ovate-lanceolate and \pm 5 -ranked, in aquatic forms greatly elongate and falcate-secund at the branch tips, apex long involute, when dry not re- separable. Sphagnum torreyanum has branch leaf chlorophyll cells always much more enclosed within the concave surface than $S$. cuspidatum, and its stem leaves are also more frequently 1-divided. In some very wet coastal fen habitats, mixed communities of $S$. pulchrum and S. torreyanum can be difficult. Careful observation, however, will reveal that S. pulchrum lacks the greatly elongate branch leaves and divided stem leaf hyaline cells of $S$. torreyanum.

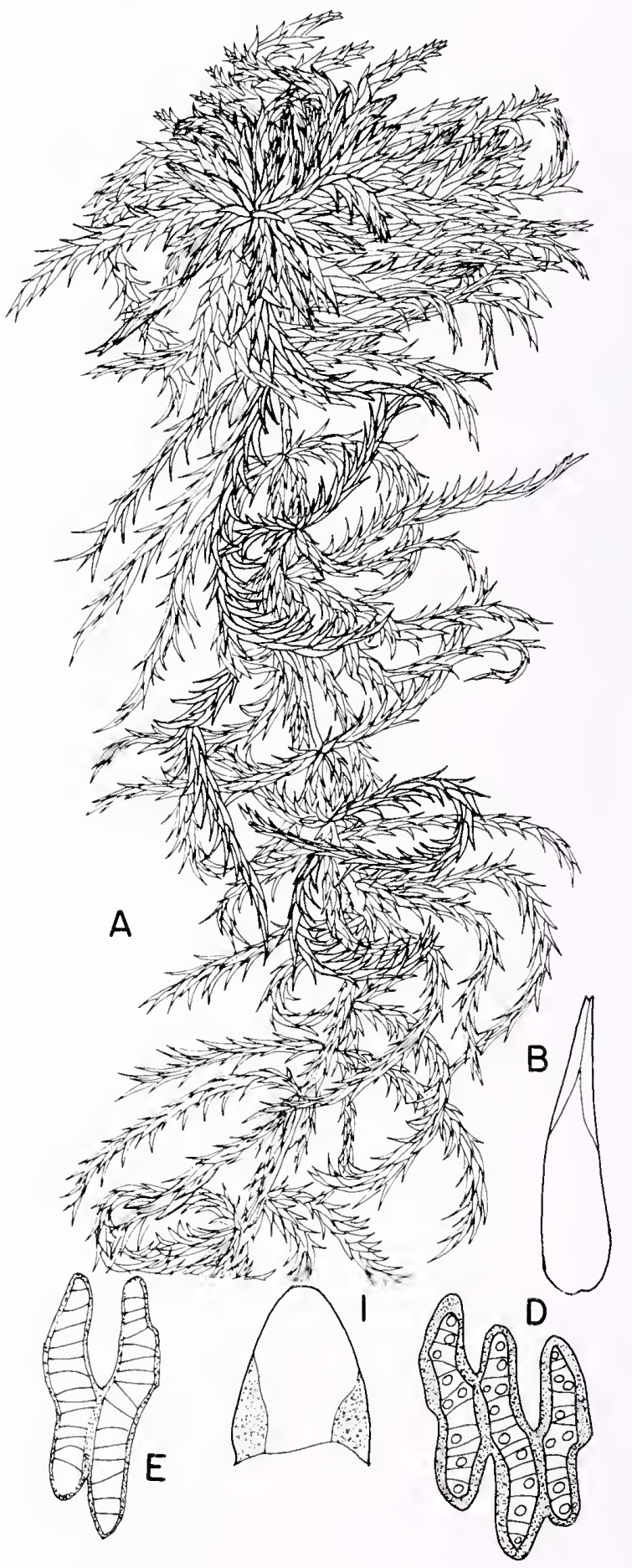


curved and not (or slightly) undulate; hyaline cells on the convex surface with numerous ( \pm 10 ), unringed, moderate-sized pores in 1-2 poorly defined rows free from the commissures, and on the concave surface, usually aporose but very rarely with pore-like wallthinnings in the cell angles; chlorophyll cells in transverse section triangular to trapezoidal, typically nar-

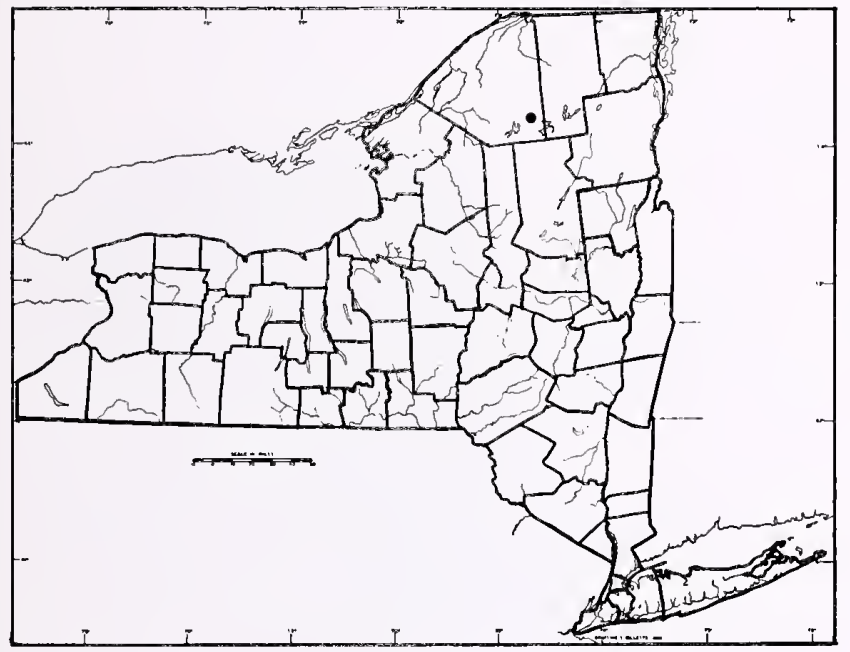

30. Sphagnum jensenii H. Lindb.

Type Description: H. Lindberg, Acta. Soc. F. Fl. Fenn. 18:3, p. 13, 1899.

Synonyms: S. propinquum H. Lindb., S. annulatum var. porosum (Schlieph. and Warnst.) Maass and Isov.

Ecology: Minerotrophic and aquatic. Ecology similar to Sphagnum majus but more minerotrophic (e.g., not found in \pm ombrotrophic bog pools with $S$. cuspidatum). Found near margins of open poor fens and in \pm medium fens, commonly associated with S. subsecundum, S. majus, S. pulchrum and S. flexuosum.

Habit: Plants \pm moderate-sized, with an aspect similar to a slender $S$. contortum. Forming lax to \pm dense carpets submerged or near water level.

General Distribution: Circumboreal, with continental tendencies. In North America from the arctic south to New York, Michigan, Minnesota, Washington, Idaho and Wyoming.

Description: Stem pale, its cortex of 2-3 layers of enlarged, moderately thin-walled cells; stem leaves triangular-lingulate, apex obtuse; hyaline cells only rarely divided and often fibrillose at the leaf apex; branch leaves ovate-lanceolate, often subsecund and infrequently 5-ranked, apex involute and in aquatic forms considerably elongated toward the branch tips, when dry not recurved and not (or slightly) undulate; hyaline cells on the convex surface with very numer- rowly exposed on the concave surface; pigments brown and red (the red very inconspicuous); plants green to dark brown; branch bases and stem very rarely red-tinged.

Distinguishing Characters: When they occur together, S. majus is usually a much deeper brown than S. cuspidatum.

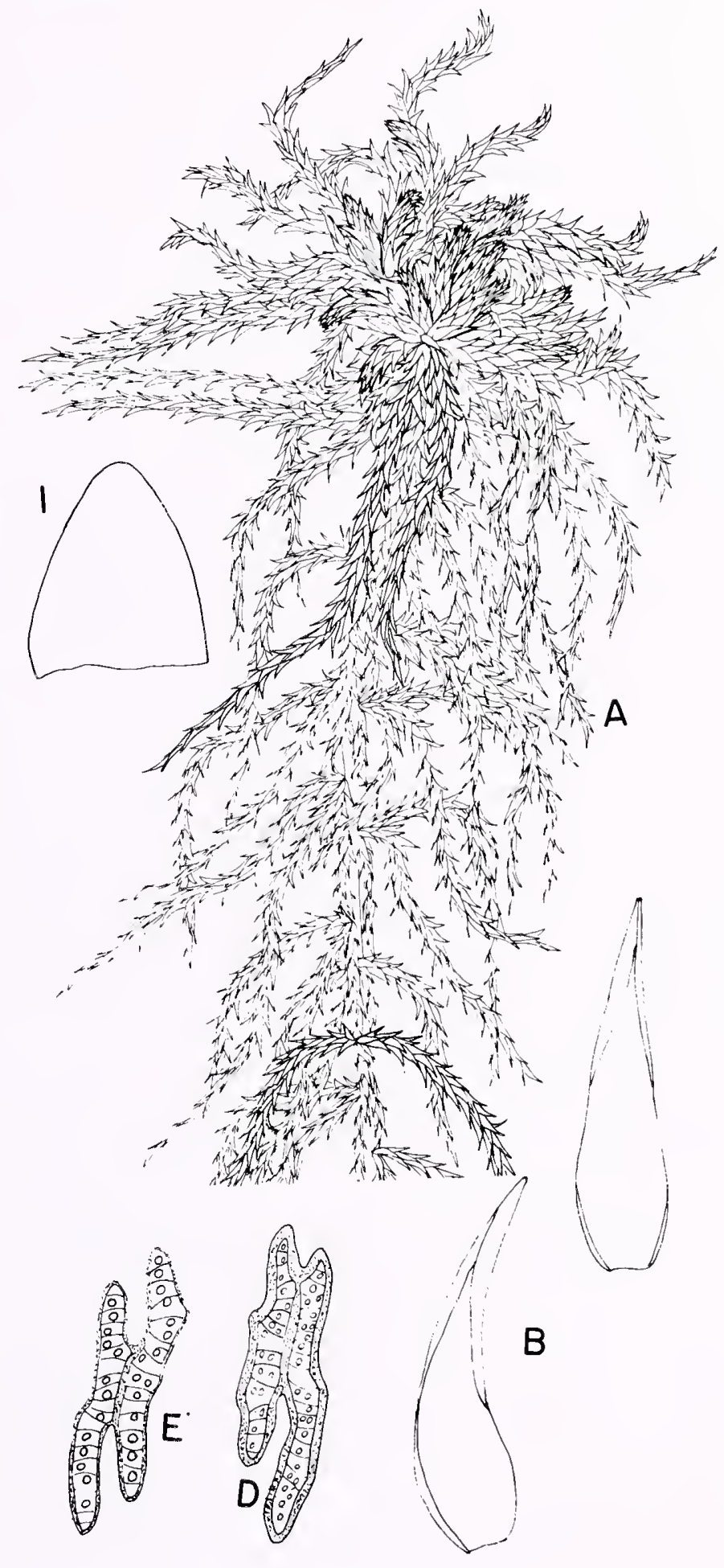


ous (typically 15-20) small, ringed and unringed, round to oval pores in $1-3$ poorly defined rows, free from the commissures, the concave surface with numerous small pores near or along the commissures; chlorophyll cells in transverse section triangular to trapezoidal, usually narrowly exposed on the concave surface; pigment brown; plants yellow-brown, orangebrown or dark brown, sometimes with a blue sheen when dry.
Note: Sphagnum obtusum Warnst. is a northern, continentally distributed member of section Cuspidata that resembles S. jensenii morphologically. Sphagnum obtusum differs in having very small and often indistinct free pores or wall-thinnings on the convex branch leaf surface, and is a strongly minerotrophic species. Since it occurs in Minnesota, S. obtusum may yet be found in New York.

\section{SECTION POLYCLADA}

A monotypic section.

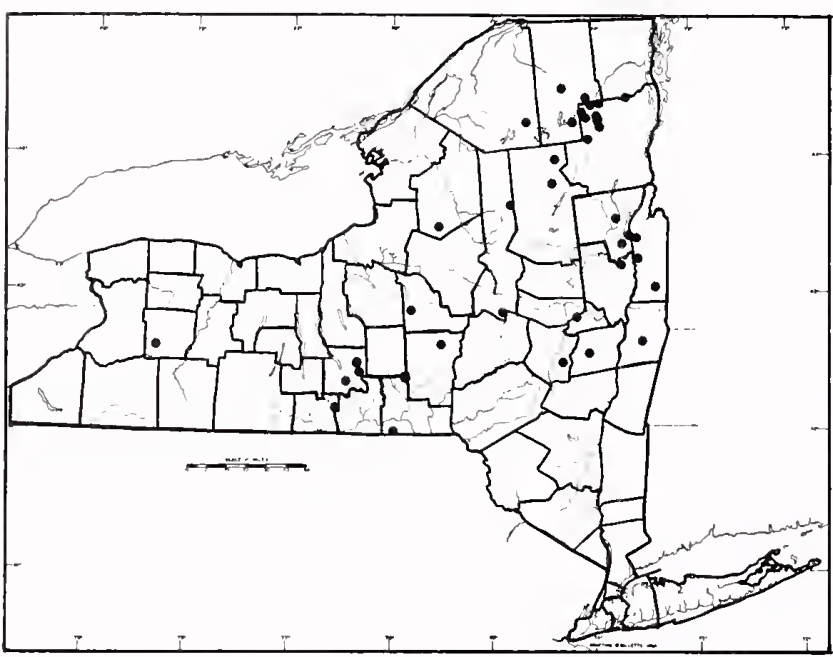

31. Sphagnum wulfianum Girg.

Type Description: Girgensohn, Arch. Nat. Dorpat $2: 173,1860$.

Ecology: Minerotrophic, our most xerophytic species. Typically found growing over damp humus in poor to medium wooded coniferous fens in association with S. squarrosum, S. centrale, S. girgensohnii and S. russowii. Also occasionally in Alnus or Salix carrs and very rarely at the margins of open fens. Widespread in mountainous regions, mostly at lower elevations.

Habit: Plants small to medium-sized, stiff, but often rising upright from a prostrate stem. Forming loose carpets.

General Distribution: Circumpolar, slightly continental. In North America from the subarctic south to Pennsylvania, Ohio, Michigan, Minnesota, Manitoba, Alberta and British Columbia.

Description: Stem cortex of 2-4 layers of enlarged cells; stem leaves small and triangular-lingulate; hyaline cells rhomboidal, efibrillose, aporose, often divided and very rarely hemiisophyllous; branch leaves 5-ranked, spreading, small, and ovatelanceolate, apex involute, border entire; hyaline cells

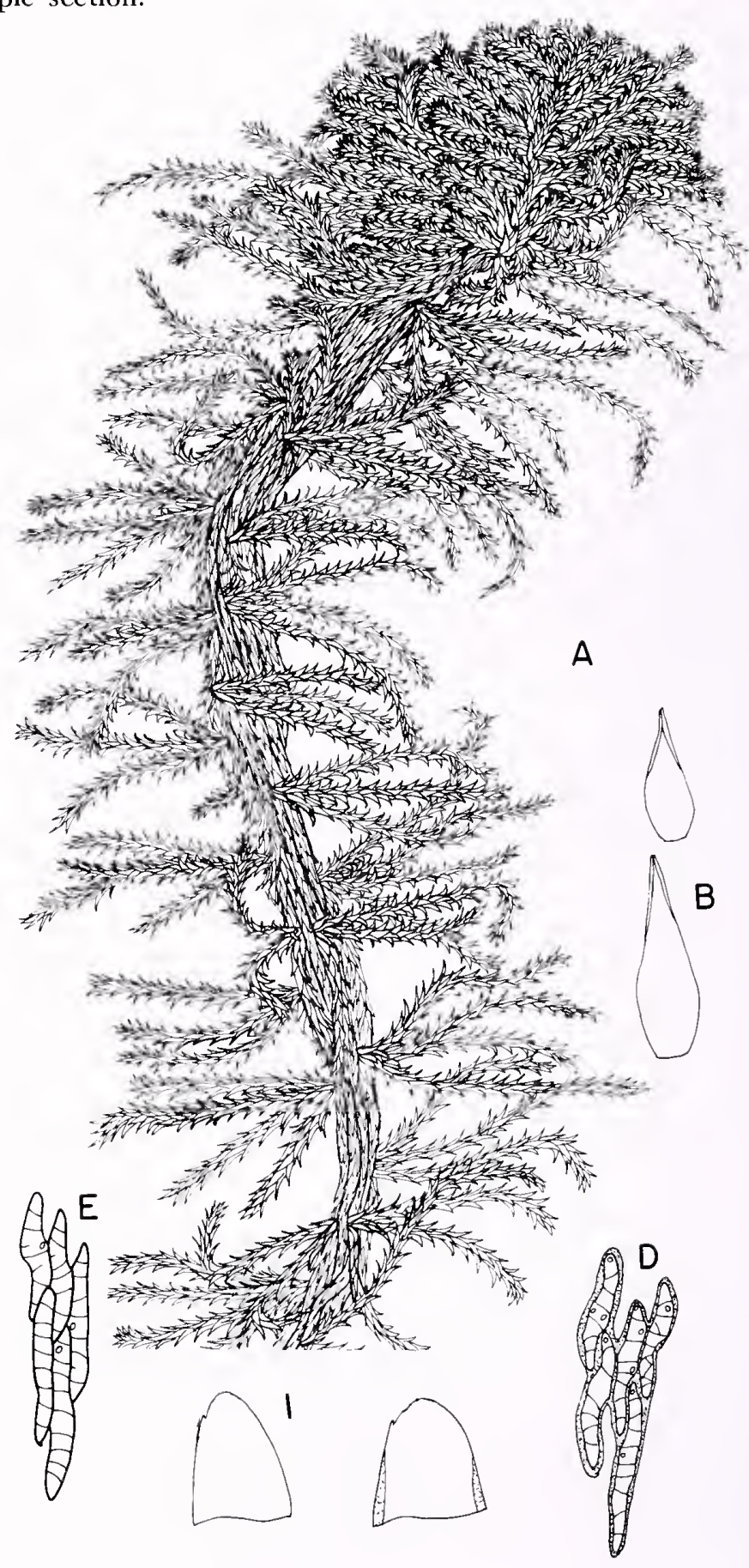


on the convex surface with small ringed pores and on the concave surface with infrequent large round pores in the lower side regions; chlorophyll cells in transverse section elliptic to truncate-elliptic, the adjoining hyaline cell walls finely papillose or smooth; pigments brown and red; plants green, brown or variegated brown and red.
Distinguishing Characters: Sphagnum uulfianum is perhaps our most easily recognized species, being the only Sphagnum with 6 or more branches per fascicle. Some forms of S. warnstorfii, S. quinquefarium and S, angustifolium look superficially similar, but all of these have 5 or fewer branches per fascicle and are easily distinguished on other characters as well.

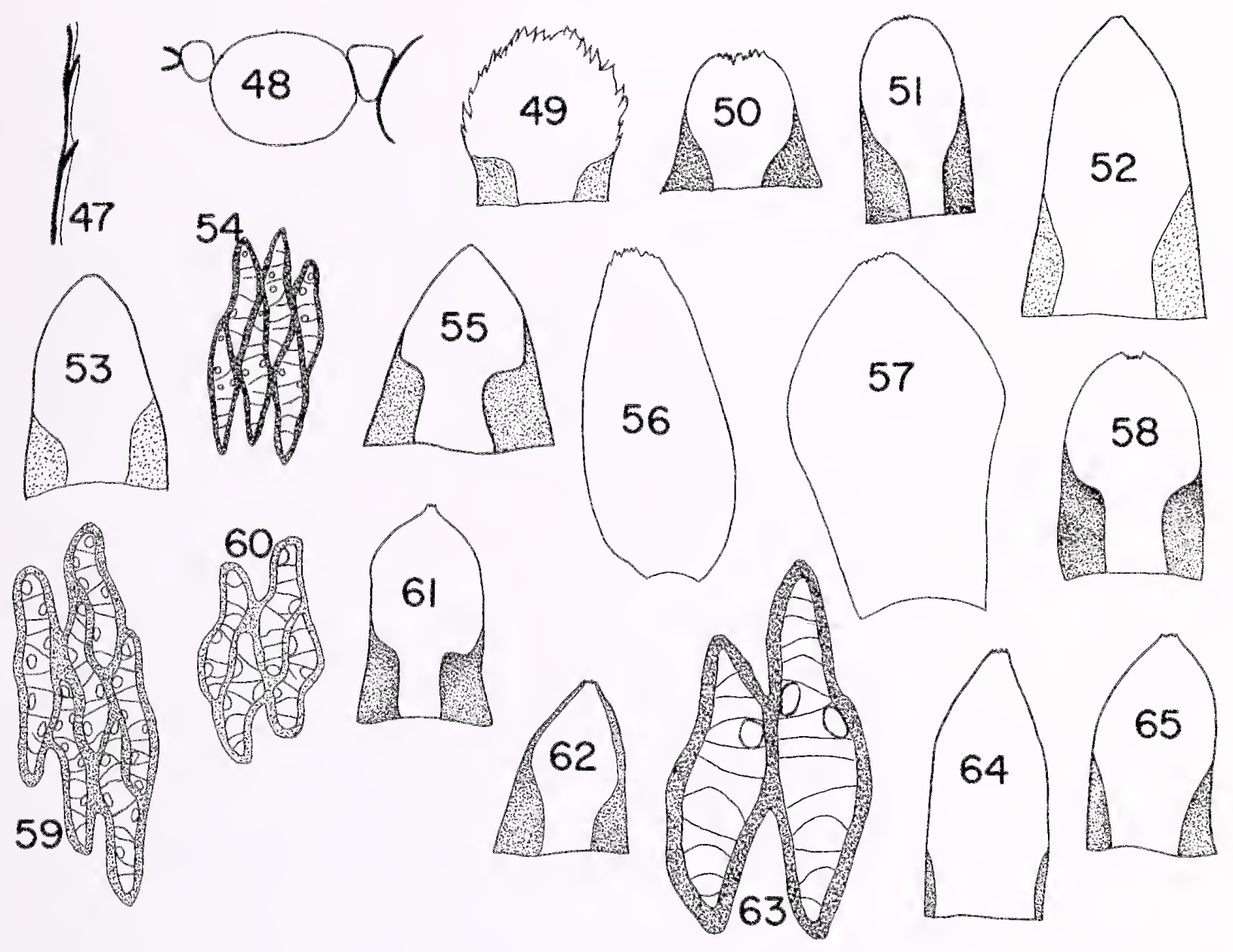

\section{SECTION ACUTIFOLIA}

Description: Stem cortex 2-4 layers of enlarged, thin-walled cells, the outer layer aporose, porose, or with wallthinnings; stem leaves triangular, triangular-lingulate, lingulate, lingulate-triangular, spatulate, ovate, or triangularovate, apex apiculate, entire, denticulate, or lacerate, border entire and slightly to strongly broadened basally; hyaline cells rhomboidal to elongate S-shaped, efibrillose or fibrillose, undivided to frequently divided, in hemiisophyllous and isophyllous forms developing pores as in the branch leaves; hyaline cells walls often resorbed on the ventral (concave) surface; branch leaves ovate to ovate-lanceolate, \pm involute above to a truncate and dentate apex, border entire (or with resorption furrow) and denticulate by projecting cell walls; hyaline cells on the convex surface with numerous very small to medium-sized round to elliptic pores throughout or in the lower side regions only, usually with small pores at the apex also; chlorophyll cells in transverse section triangular or trapezoidal, the broad base exposed on the concave surface; hyaline cells smooth throughout; pigments brown and reddish-purple, sometimes with a violet tinge. 


\section{KEY TO SPECIES OF SECTION ACUTIFOLIA}

1. Branch leaves denticulate margined (Fig. 47), with resorption furrow (Fig. 48) ......46. S. molle (p. 82)

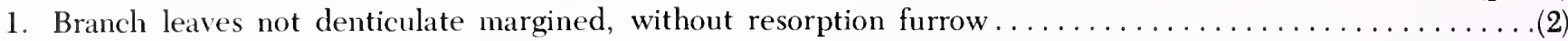

2. Stem leaves with a broad lacerate to fimbriate apex (Figs. 49 and 50), plants never red pigmented...(3)

2. Stem leaves without a broad fimbriate apex, plants red or brown pigmented

3. Stem leaves lacerate across the apex and down the sides (Fig. 49), plants slender and often with a conspicuous

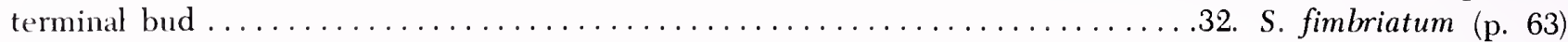

3. Stem leaves fimbriate across the apex (Fig. 50), plants larger and very rarely with a conspicuous terminal bud

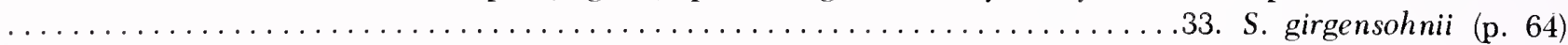

4. Plants brown pigmented, lacking purplish-red, the stem brown even in green forms; branch leaves very

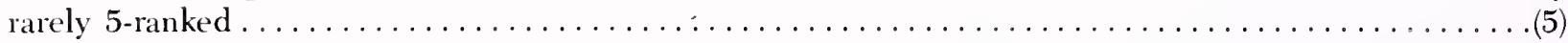

4. Plants purplish-red pigmented, in pale forms the pigment sometimes not discernable; branch leaves va-

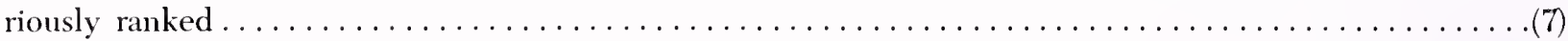

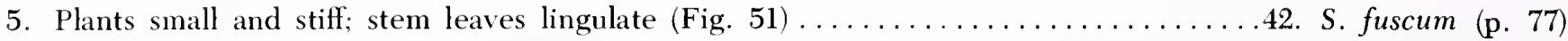

5. Plants moderate-sized to large; stem leaves lingulate-triangular (occasionally lingulate in S. subfulvum)...(6)

6. Plants large and stiff; stem leaves large, narrowly lingulate-triangular (Fig. 52) and normally fibrillose above; an oceanic Atlantic North American coast endemic found from Newfoundland to New Jersey ....

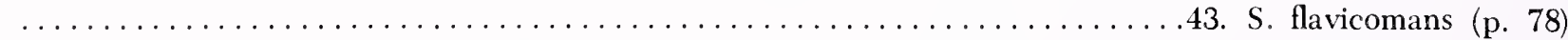

6. Plants \pm moderate-sized and soft; stem leaves moderate-sized, lingulate-triangular to lingulate (Fig. 53) and normally efibrillose above; a northern circumboreal species found southward to New York, Michigan and Minnesota ...................................44. S. subfulvum (p. 79)

7. Branch leaf hyaline cells in the apical region of the convex surface with very small, round and strongly ringed pores (Fig. 54); branch leaves typically sharply 5-ranked and not subsecund .....35. S. warnstorfii (p. 66)

7. Branch leaf hyaline cells in the apical region of the leaf with small to medium-sized, round to elliptic, moder-

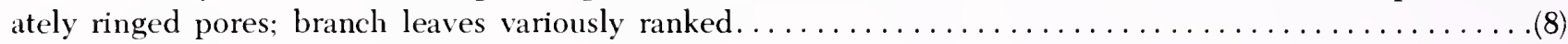

8. Stem leaves triangular (Fig. 55); branch leaves stiffly 5-ranked; spreading branches typically 3 per fascicle

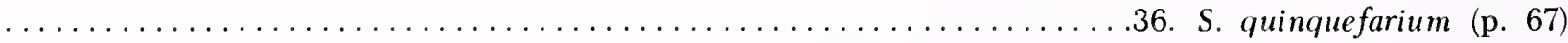

8. Stem leaves not triangular; branch leaves variously ranked; spreading branches typically 2 per fascicle (9)

9. Branch leaves with a conspicuously broad dentate apex bearing 6-10 teeth (Fig. 56); hyaline cells with large round pores throughout on the concave branch leaf surface; stem leaves large and lingulate-triangular, broadest above the middle (Fig. 57); capitulum typically with strongly flattened head branches; an oceanic, amphiatlantic species, rare outside of Nova Scotia ...............45. S. angermanicum (p. 81)

9. Branch leaves with up to 6 apical teeth; hyaline cells with large round pores variously distributed on the concave branch leaf surface; stem leaves not broadest above the middle; capitulum without flattened head

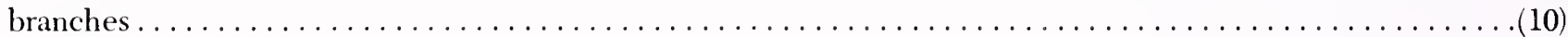

10. Stem leaves strongly lingulate and often fimbriate at the apex (Fig. 58); outer stem cortical layer normally

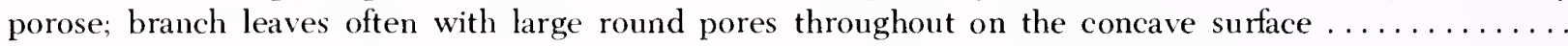
$\ldots \ldots \ldots \ldots \ldots \ldots \ldots \ldots \ldots \ldots \ldots \ldots \ldots \ldots \ldots \ldots \ldots \ldots \ldots \ldots \ldots \ldots \ldots \ldots \ldots \ldots \ldots \ldots \ldots$ S. russowii (p. 65)

10. Stem leaves variously shaped, not lacerate at the apex; onter stem cortical layer very rarely porose; branch leaves with large round pores normally restricted to the lower side regions (throughout in $S$.

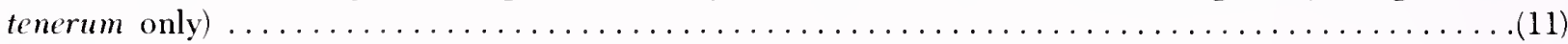

11. Stem leaves lingulate; hyahine cells $1-2$ divided; soft and often hydrophytic plants .............(12)

11. Stem leaves triangular-lingulate, lingulate-triangular, or triangular-ovate (sometimes lingulate in $S$. subtile);

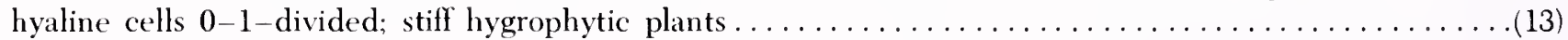

12. Branch leaves 5-ranked and subsecund on at least some branches; two hanging branches per fascicle; hyaline cells in the apical region of the convex sufface with predominantly small round pores (Fig. 59); stem leaf hyaline cells often 2-divided; stem leaf apex not apiculate ......... S7. rubellum (p. 68)

12. Branch leaves unranked, not subsecund; one hanging branch per fascicle; hyaline cells in the apical region of the convex surface with predominately moderate-sized elliptic pores (Fig. 60); stem leaf hyaline cells normally only 1 -divided; stem leaf apex often apiculate (Fig. 61) ......38. S. andersonianum (p. 70)

13. Stem leaves triangular-lingulate to lingulate (Fig. 62), nomally efibrillose, border strongly broadened basally

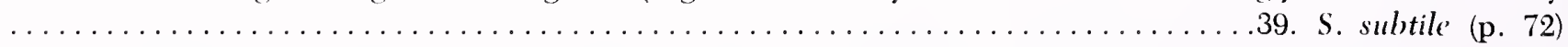

13. Stem leaves hingulate-triangular to triangular-ovate, usually fibrillose above, border moderately to weakly broadened basally. 
14. Branch leaves with large round pores throughout on the concave surface (Fig. 63); stem leaves with very lax areolation, often porose on both surfaces, border little broadened basally (Fig. 64); branches thick and turgid; a temperate to subtropic Western Hemisphere Atlantic coast endemic ...44. S. tenerum (p. 74)

14. Branch leaves with large round pores restricted to the lower side regions on the concave surface; stem leaves with moderately lax areolation, normally aporose or with pores on the convex surface only, border moderately broadened basally (Fig. 65); branches slender; a widespread northern circumboreal species $\ldots \ldots \ldots \ldots \ldots \ldots \ldots \ldots \ldots \ldots \ldots \ldots \ldots \ldots \ldots \ldots \ldots \ldots \ldots \ldots$. n. nemoreum (p. 73)

\section{MULTIPLE-ACCESS KEY TO SPECIES OF SECTION ACUTIFOLIA}

\section{Character}

Stern cortex

Stem leaf shape

Stem leaf apex

Stem leaf margin

Stem leaf hyaline cell septation

Hanging branches/fascicle

Spreading branches/fascicle

Branch leaf ranking

Branch leaf habit

Branch leaf margin

Branch leaf apex
Character State

\section{STEM CORTEX}

1. with pores or wall-thinnings: $32,33,34$

2. lacking pores or wall-thinnings: $34-46$

\section{STEM LEAVES*}

3. spatulate: 32,33

4. ovate: 46

5. lingulate: $33,34,35,37,38,39,44,45,46$

6. lingulate-triangular: $40,41,43,44,45,46$

7. triangular-lingulate: $35,39,41$

8. triangular: 36,41

9. lacerate or fimbriate across broad flat apex: 32,33

10. fimbriate across $1 / 4$ to $1 / 2$ apex: 34

11. entire except for very tip: $34-46$

12. apiculate: 38,43

13. acute to obtuse: $33-46$

14. fimbriate to lacerate: 32

15. entire: all others

16. $\leq 20 \%$ septate: 32,33

17. cells $>20 \%$ once septate: all but 33

18. cells $>20 \%$ twice septate: 37

19. one: 38

20. two: all others

21. three: 36

22. two: all others

\section{BRANCH LEAVES}

23. 5-ranked: $35,36,37,39$

24. not 5-ranked: all

25. falcate-secund: 37

26. not falcate-secund: all but 37

27. imbricate: $32,33,34,39,40,41,42$, $43,44,45,46$

28. lax and/or spreading: $35,36,37,38,39,46$

29. serrulate: 46

30. entire: all others

31. broad, flat and conspicuously toothed: $41,45,46$

32. narrow, involute and inconspicuously toothed: $32,33,34,35,36,37,39,40,42,43,44$

33. concave but not involute: $37,38,46$ 
Branch leaf convex surface

pore (in apical region) shape

Branch leaf convex surface pore size

Branch leaf concave surface pores

Color (at least in part)

34. round: $34,35,36,37,39,42$

35. elliptic: $32,33,34,36,37,38,39,40$ $41,42,43,44,45,46$

36. $\leq 2 \mu: 35$

37. $>2 \mu$ : all others

38. present throughout upper $1 / 2$ of leaf: 41,45

39. restricted to apex and lower side regions: $32,33,34,35,36,37,38,39,40,42,43,44,46$

\section{COLOR}

41. brown: $32,33,42,43,44$

42. red: $34,35,36,37,38,39,40,41,44,45,46$

43. green: all

44. with metallic sheen when dry: $35,38,43,44,45$

45. lacking metallic sheen when dry: all

\section{SPECIES LIST*}

32. S. fimbriatum; 33. S. girgensohnii; 34. S. russowii; 35. S. warnstorfii

36. S. quinquefarium; 37. S. rubellum; 38. S. andersonianum; 39. S. subtile

40. S. nemoreum; 41. S. tenerum; 42. S. fuscum; 43. S. flavicomans

44. S. subfulcum; 45. S. angermanicum; 46. S. molle

* The stem characters given are for anisophyllous forms. Stem leaves that are fibrillose over more than one half their surface will not work well in this key. Plants with such stem leaves are difficult to key out, but can often be determined using other characters. 


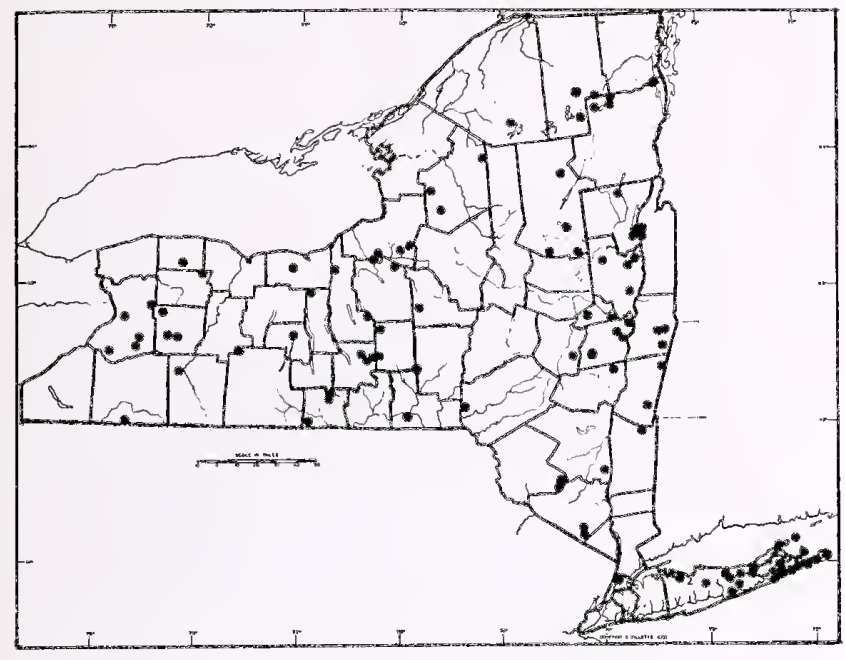

32. Sphagnum fimbriatum Wils.

Type Description: Wilson in Hooker, Crypt. Bot. Antarct. Voyage, p. 92, 1846.

Ecology: Minerotrophic. Common at the mineral soil edges of bogs and poor fens, associated with such species as Sphagnum russowii, S. centrale, S. palustre, S. imbricatum, S. henryense, S. fallax and Drepanocladus exannulatus. Also in poor to medium open and wooded fens, associated with such species as $S$. imbricatum, S. centrale, S. teres and S. warnstorfii.

Habit: Plants typically small and slender, sometimes compact; the small capitulum normally with a conspicuous terminal bud. Typically forming low hummocks or dense carpet patches.

General Distribution: Circumpolar and bipolar. In North America from the arctic south to West Virginia, Ohio, Indiana, Illinois, Iowa, South Dakota Colorado, Idaho and California.

Description: Stem pale green to straw-colored with the outer stem cortical layer mostly with 1 --several pores per cell; stem leaves large, broad-spatulate, strongly lacerate across the apex and partway down the sides, border narrow and scarcely broadened basally; hyaline cells rhomboidal, efibrillose and often 12 divided; branch leaves small, ovate, imbricate, not 5 -ranked, involute apically with the hyaline cells on the convex surface with numerous elliptic pores along the commissures, grading from small pores at the leaf apex to large pores at the leaf base, on the concave surface with large round pores at the leaf apex and side regions; pigment brown; plants green to yellowish-brown.

Distinguishing Characters: Sphagnum fimbriatum is usually easily recognized by its slender aspect, conspicuous terminal bud, and often abundant sporo-

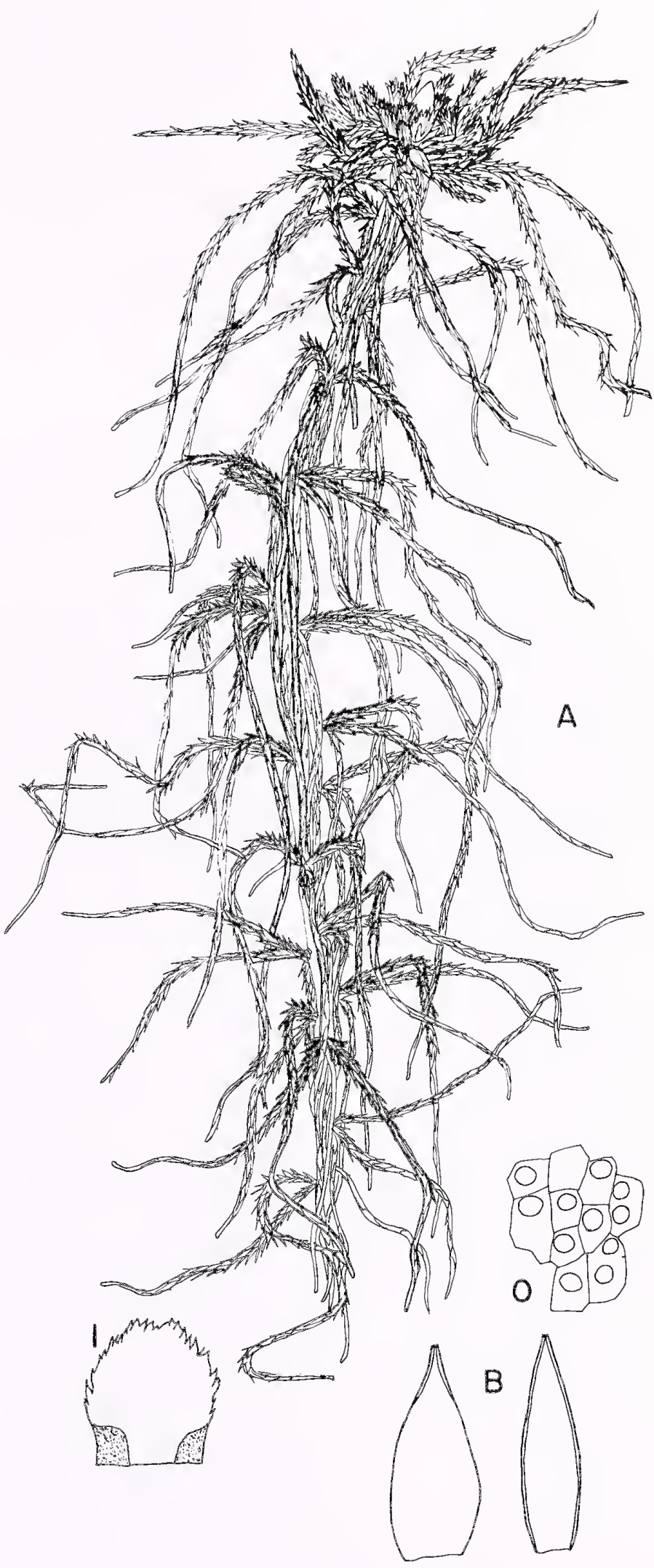


phytes (no other Sphagnum species fruits more freely). Large plants may resemble small forms of Sphagnum teres but the latter has smaller, more lingulate, less lacerate stem leaves and a brown stem. The branch

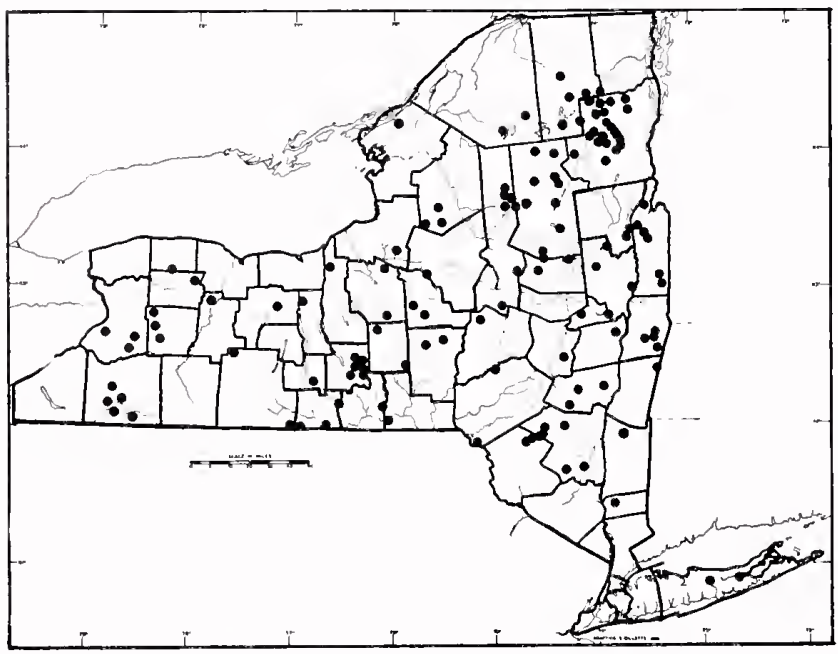

\section{Sphagnum girgensohnii Russow}

Type Description: Russow, Arch. Naturk, Liv-EhstKurl. ser. 2, 7: 46, 1865.

Ecology: Minerotrophic. Near mineral soil margins of open mires and ponds with such species as Sphagnum russowii, S. centrale, S. fallax, and S. fimbriatum and in wooded poor to medium fens associated with $S$. warnstorfii, S. centrale, S. fimbriatum, S. russowii, and S. subtile. In mountainous regions very widespread forming carpets in poorly drained, forested habitats and along small streams up through the subalpine zone, often associated with S. russowii. A very shade-tolerant species.

Habit: Plants moderate-sized to robust, open, stiff and slender, less frequently \pm compact; capitulum flat, often large and distinctly 5-parted. Plants forming open to dense carpets.

General Distribution: Circumpolar. In North America from the arctic south to North Carolina, Tennessee, Ohio, Indiana, Illinois, Iowa, North Dakota, Alberta, Idaho and Washington.

Description: Stem pale green to yellow-brown, outer stem cortical layer mostly with 1 pore per cell, rarely aporose; stem leaves lingulate, broad-lingulate, or lingulate-spatulate, apex broad, truncate and lacerate, border strong and much broadened basally; hyaline cells rhomboidal, efibrillose, and rarely divided; branch leaves small, ovate, imbricate (except in rare squarrose forms), strongly involute apically and never 5 -ranked; hyaline cells on the convex surface with numerous elliptic pores along the commissures, grading from small pores at the leaf apex to large pores at the leaves of $S$. teres, especially in small forms, are often squarrose in shaded portions of the plant; branch leaves of $S$. fimbriatum are not.

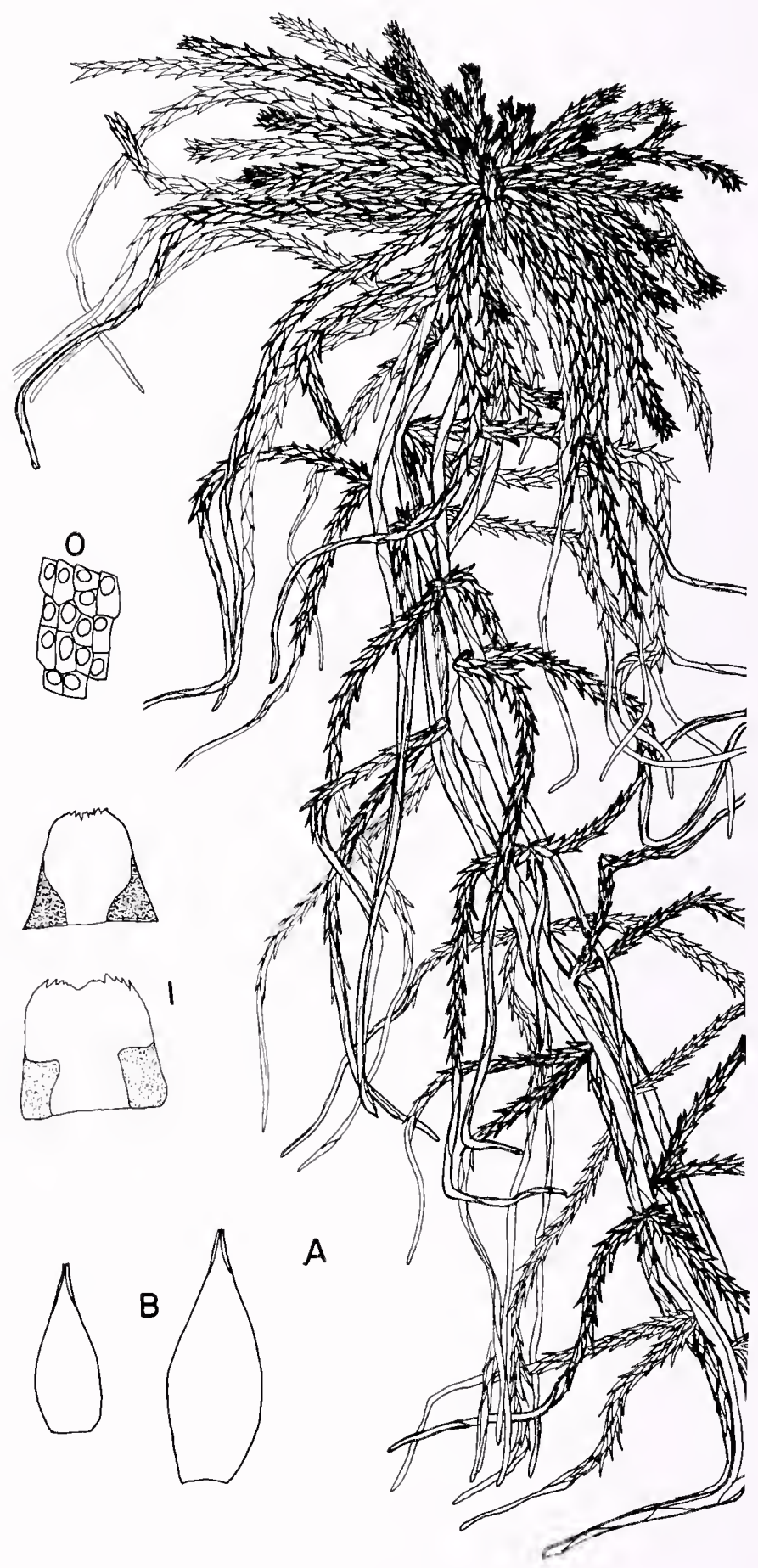


leaf base, concave surface with large round pores at the leaf apex and side regions; pigment brown; plants typically deep green in shade-grown forms to yellowish-brown in sun-grown forms.

Distinguishing Characters: Sphagnum girgensohnii is often confused with $S$. russowii without red pigment. Sphagnum russowii and S. girgensohnii, however, also differ clearly in stem leaf morphology, with the latter having shorter and broader stem leaves with the hyaline cells less divided and the apex lacerate over a broader portion. Forms of $S$. teres with pore-like wallthinnings in the cortex may also be confused with $S$. girgensohnii, but $S$. teres has a much darker stem and

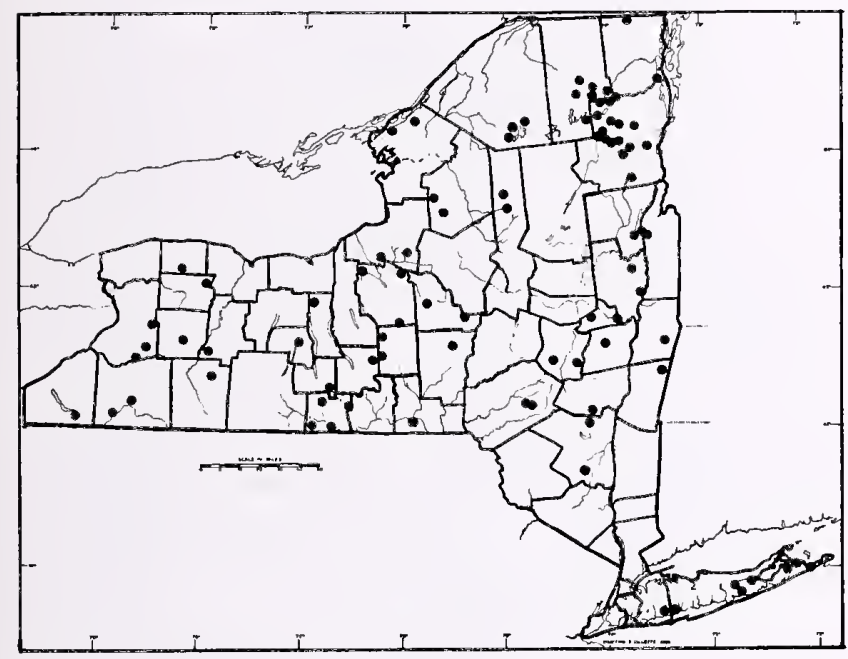

34. Sphagnum russowii Warnst.

Type Description: Warnstorf, Hedwigia 25: 225, 1886. Synonym: S. robustum (Warnst.) Card.

Ecology: Minerotrophic. Shade tolerant. Common up to timberline in mountainous regions in wet coniferous forests, often associated with $S$. girgensohnii. Associated with S. centrale, S. squarrosum, S. fallax, S. fimbriatum and $S$. girgensohnii at the margins of bogs and fens; also found in low hummocks and sides of hummocks in open portions of poor to rich fen. Although a widespread species with a broad ecological amplitude, S. russowii is seldom very abundant, occurring instead as scattered plants or small stands.

Habit: Plants \pm moderate-sized; stiff and open; compact on exposed sites; capitulum flat and often 5parted; aspect of a small, slightly stout S. girgensohnii. Forming dense carpets and low hummocks.

General Distribution: Circumpolar. North American distribution unclear due to confounding with other members of section Acutifolia. From the arctic south to at least North Carolina, Kentucky, Missouri, Iowa, Colorado, Utah, Idaho, and California. stem leaves are fimbriate partway down the sides. Infraspecific Variation: Sphagnum girgensohnii becomes hemiisophyllous fairly easily and may then be impossible to distinguish from unpigmented hemiisophyllous forms of $S$. russowii and S. nemoreum, particularly since such plants are often aberrant in characters that might provide alternative means of determination.

Importance: An ecologically important ground cover plant in poorly drained, higher elevation portions of the Adirondack region, but never a significant peatformer.

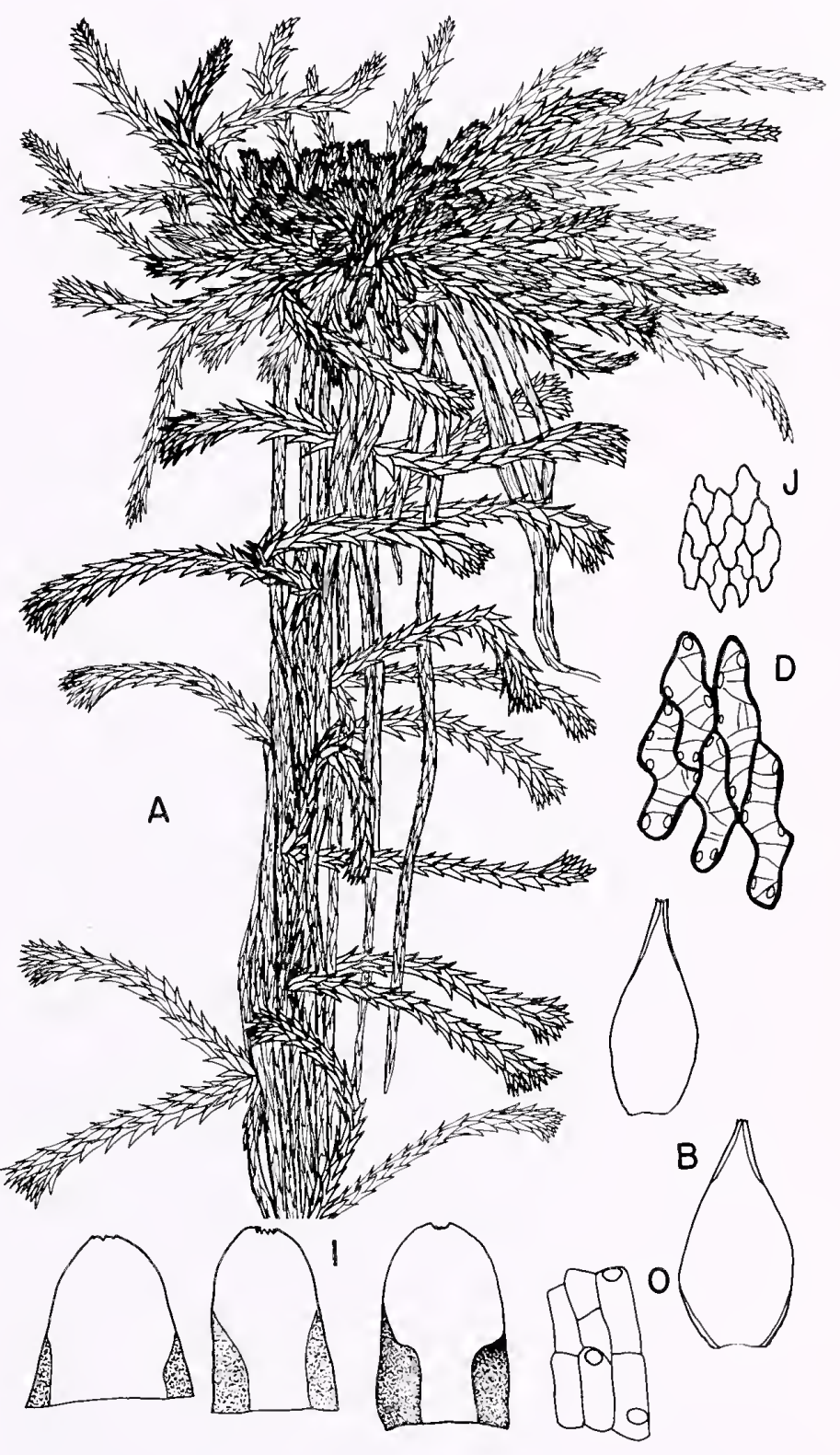


Description: Stem typically mixed green and red with the outer stem cortical layer having many cells bearing one round pore (porose cells sometimes infrequent or absent); stem leaves moderate-sized and lingulate, the apex broadly rounded, notched and denticulate to lacerate at the center, border strong and much broadened basally; hyaline cells short sinuoidrhombic, efibrillose and 0-1 divided (except in hemiisophyllous forms); branch leaves moderate-sized, ovate-lanceolate, imbricate, strongly involute apically and never 5-ranked; hyaline cells on the convex surface with numerous round to elliptic pores along the commissures, grading from small round pores at the

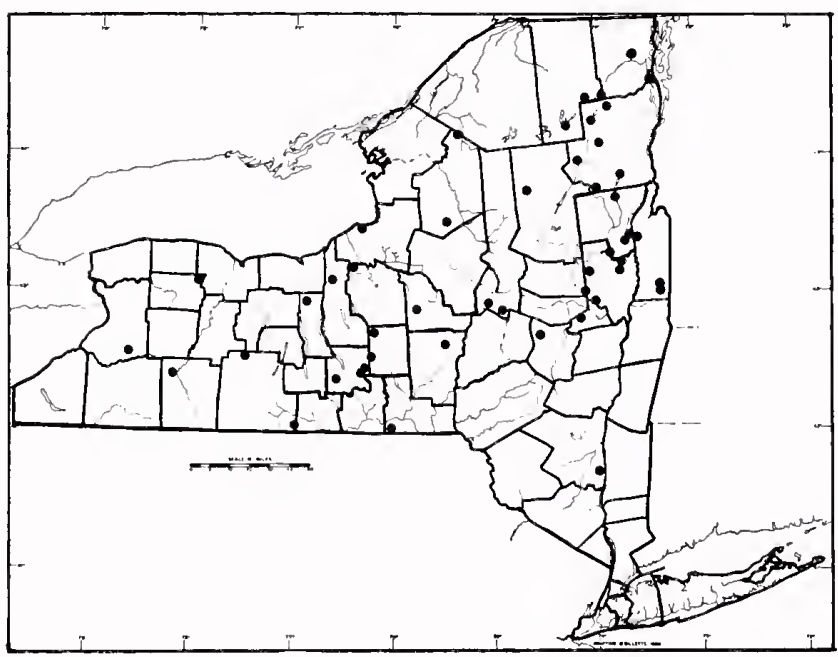

\section{Sphagnum warnstorfii Russow}

Type Description: Russow, Sitzungsber. Naturf. Ges. Dorpat 8:315, 1887.

Synonym: S. warnstorfianum DuRietz

Ecology: Strongly minerotrophic. Hygrophytic. Frequent in medium to rich fens. Commonly associated with Thuja occidentalis, Abies balsamea and Picea rubens in richer wooded mires. Typical associated bryophytes include $S$. teres, S. centrale, S. squarrosum, Calliergonella cuspidata and Campylium stellatum.

Habit: Plants small, less frequently moderate-sized; slender; capitulum flat-topped and often 5-parted. Forming loose carpets and low hummocks.

General Distribution: Circumpolar, with continental tendencies. In North America occurring from the arctic south to New Jersey, Pennsylvania, Ohio, Indiana, Illinois, Wisconsin, Minnesota, South Dakota, Colorado, Utah, Idaho, and California.

Description: Stem red to green with the outer stem cortical layer aporose; stem leaves small and triangular-lingulate to lingulate, apex broadly rounded or sometimes pointed, border very strong and much apex to large, elliptic pores basally, the concave surface typically with large, round pores throughout, but these sometimes restricted to the lower side-regions; pigment purplish-red; plants green or variegated red and green.

Infraspecific Variation: Because of the high frequency of hemiisophyllous forms and its broad ecological amplitude, S. russowii, like S. nemoreum, can be a difficult species to separate. Modified forms of $S$. russowii are often determined as $S$. nemoreum, and indeed may not always be separable. (See also under $S$. girgensohnii.)

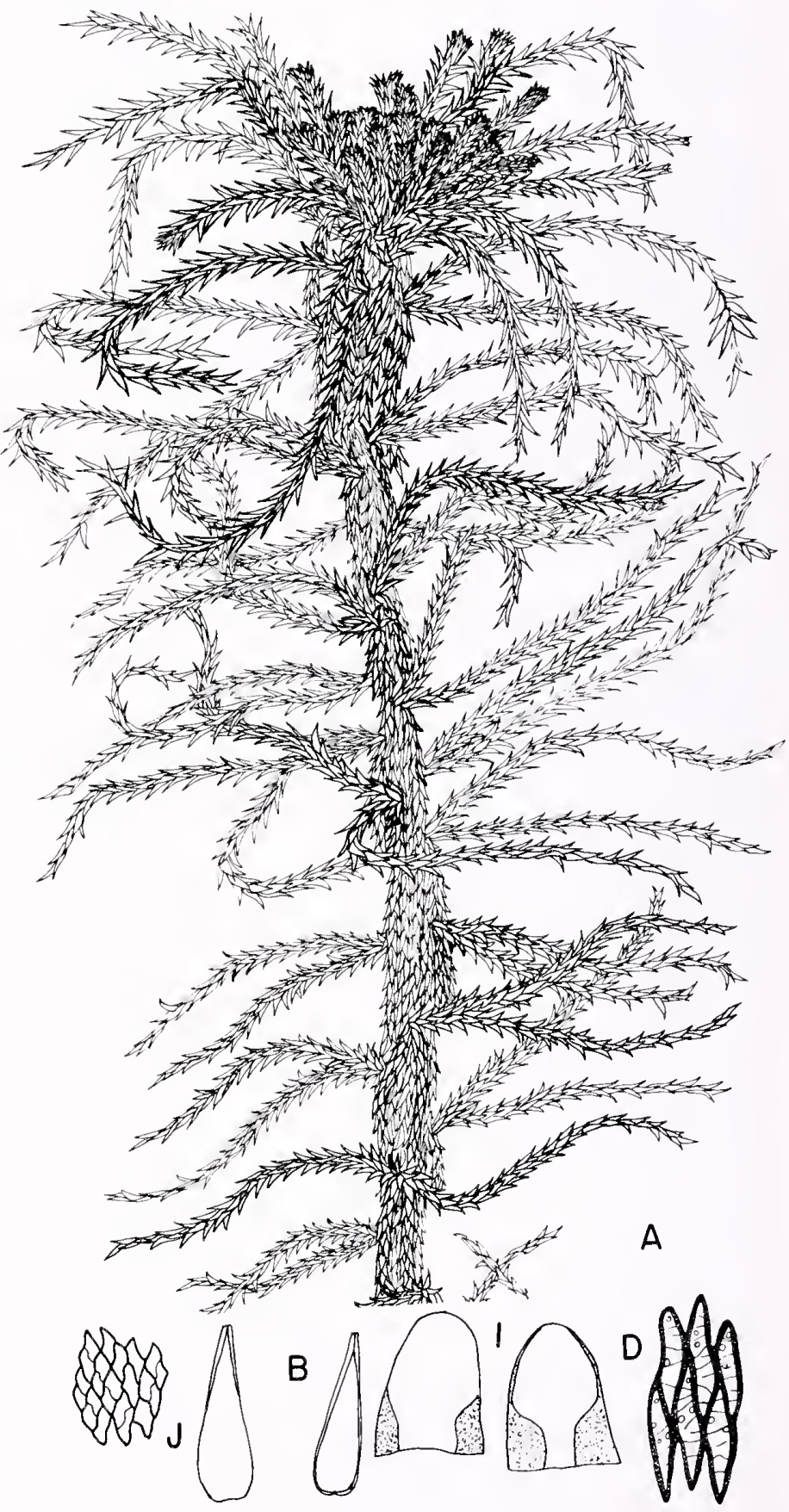


broadened basally; hyaline cells small, rhombic, 1divided and normally efibrillose; branch leaves small, ovate-lanceolate, spreading, 5-ranked and involute apically; hyaline cells on the convex surface with very small ringed pores along the commissures near the leaf apex, changing abruptly to large elliptical pores basally, the concave surface with large round pores in the lower side-regions; pigment purplish-red; plants green or dark purplish-red and green, rarely red throughout.

Distinguishing Characters: Sphagnum warnstorfii is

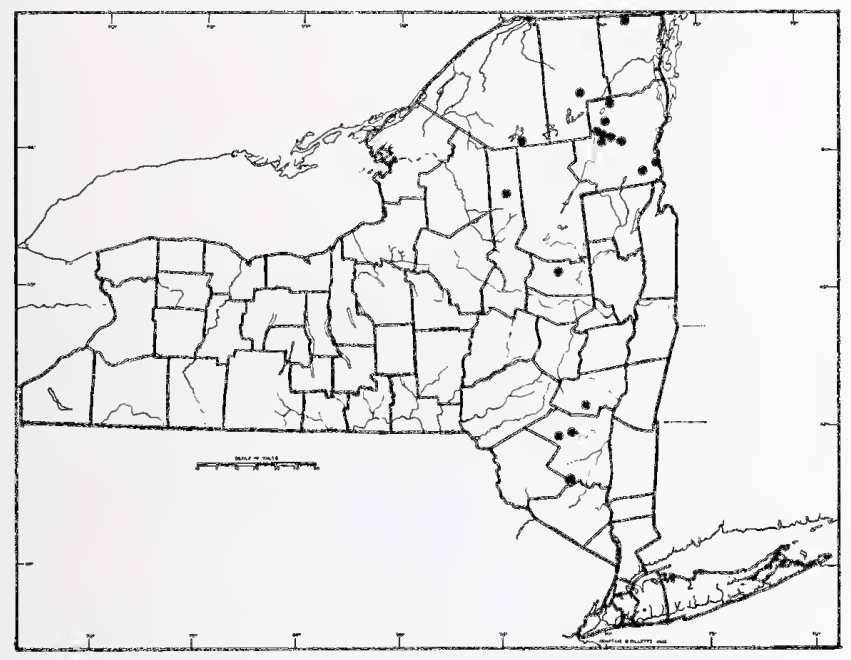

\section{Sphagnum quinquefarium (Braithw.) Warnst.}

Type Description: Warnstorf, Hedwigia 25: 222, 1886. Synonym: S. bartlettianum auct., non Warnstorf.

Ecology: Weakly minerotrophic. Hygrophytic. Found in drier sites than nearly any other New York Sphagnum. In New York, on wet mineral detritus and rock in mountainous regions, often on the side or base of a rock face. Also on damp coniferous humus at higher elevations. Prefers shaded microsites. Commonly associated species include $S$. girgensohnii, S. russowii, and S. nemoreum.

Habit: Plants of \pm moderate size; typically stiff and compact; capitulum typically hemispherical. Plants forming compact low cushions or carpets.

General Distribution: Amphiatlantic and east-pacific (possibly amphipacific), absent from much of continental interior. In eastern North America from Newfoundland and eastern Quebec south through New England to New York and from there south in the higher Appalachian Mts, to North Carolina (Michigan and Minnesota). On the Pacific coast from Alaska to Oregon.

Description: Stem pale green or yellowish, rarely redtinged, the outer cortical stem layer aporose, porose, or with faint round to hemispherical wall-thinnings; found in much more minerotrophic habitats than similar Acutifolia members, and is normally easily recognizable by its small, straight, spreading and sharply 5ranked branch leaves. Microscopically, the best eharacter is the convex branch leaf surface with very small, strongly ringed pores at the leaf apex, that change rather abrupted (at mid-leaf) to the large elliptic pores found basally. All other members of the New York Acutifolia have larger apical pores that exhibit a gradual transition in size to the large elliptic pores of the basal area.

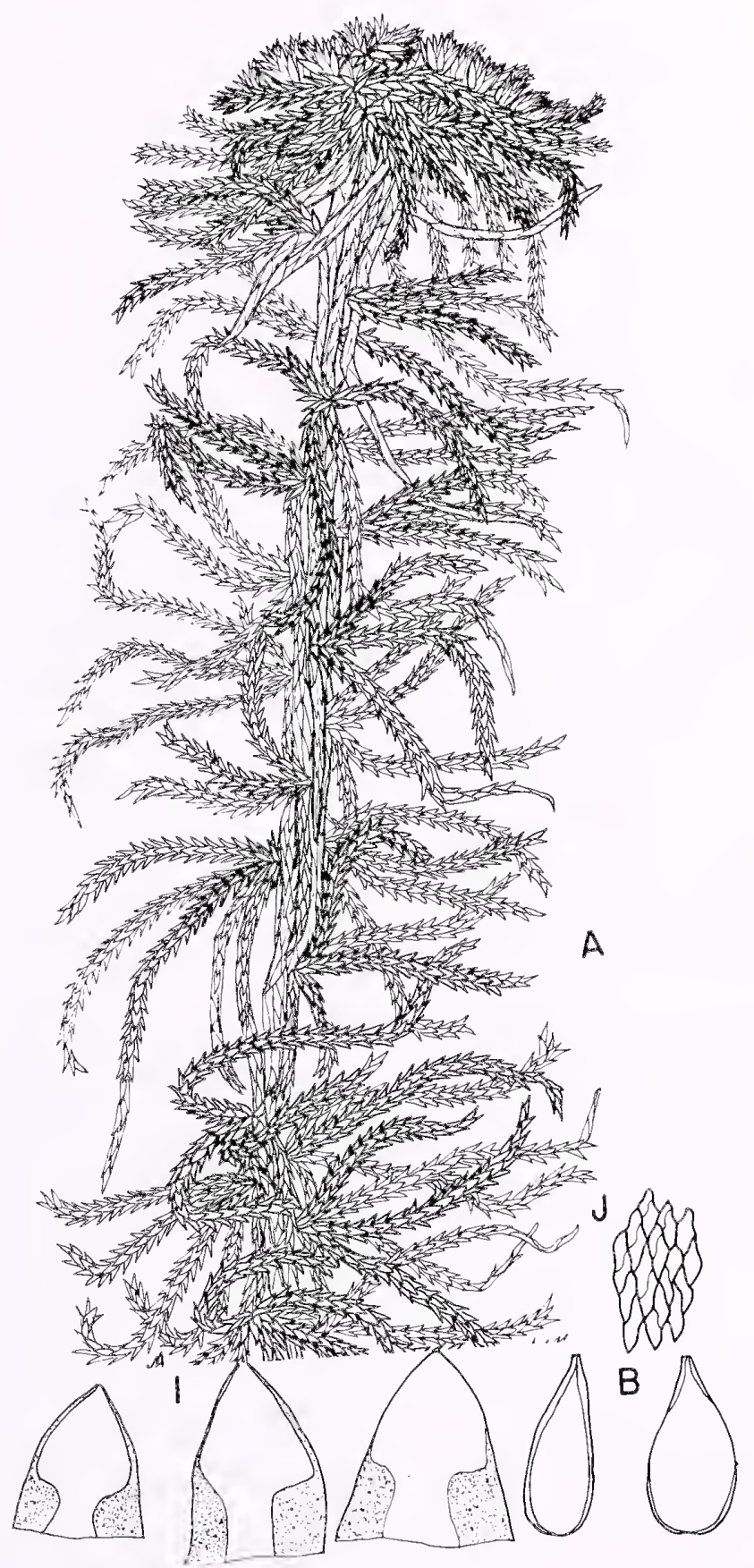


stem leaves small to moderate-sized, triangular to lingulate-triangular, involute above and usually apiculate, border strong and greatly broadened basally; hyaline cells narrowly rhomboidal, mostly 1-divided and normally efibrillose; branch leaves small, ovate to ovate-lanceolate, imbricate to loosely spreading, typically stiffly 5 -ranked and slightly involute apically; hyaline cells on the convex surface with numerous round to elliptic pores along the commissures, grading from small pores at the leaf apex to large pores at the leaf base, the concave surface with large round pores in the lower side-regions; pigment purplish-red; plants green, grayish-white, pale yellow, purplish-red, sometimes with a metallic luster when dry.

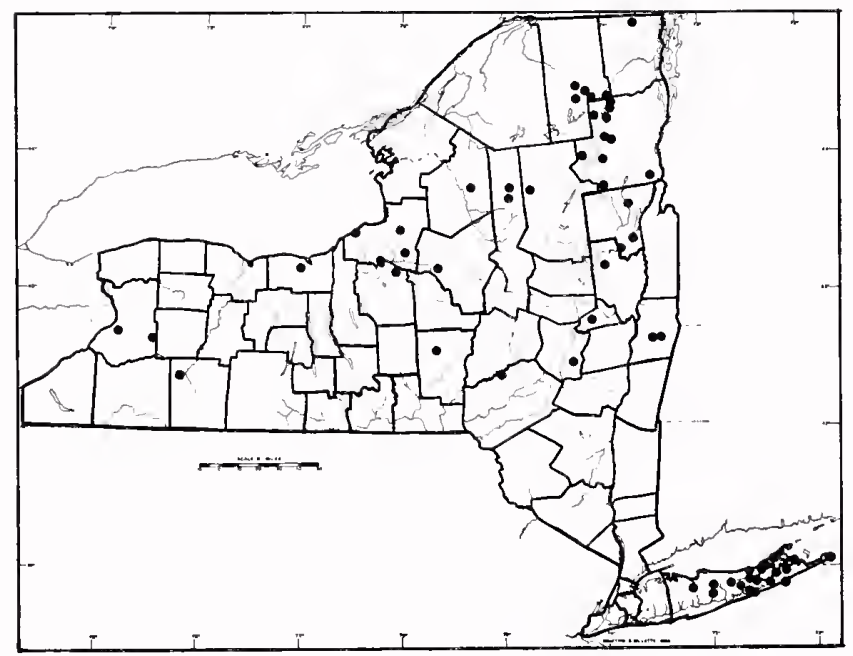

\section{Sphagnum rubellum Wils.}

Type Description: Wilson, Bryol. Brit., p. 19, 1855. Synonyms: S. capillaceum var. tenellum (Schimp.) Andrews, S. capillifolium var. tenellum (Schimp.) Crum.

Ecology: Ombrotrophic. Hydrophytic. In coastal regions forming hummocks and carpets in raised bogs and poor fens. Associated species on Long Island include S. papillosum, S. cuspidatum, S. torreyanum, S. recurvum, S. fallax and S. magellanicum; further north along the coast, S. pulchrum, S. tenellum and S. fuscum become important associates. At inland locations it less frequently forms hummocks, but instead is usually found in wet carpets, especially floating mats, with S. papillosum, S. fuscum, S. cuspidatum, S. fallax, S. angustifolium and S. magellanicum.

Habit: Plants small to moderate-sized; slender and open, less often compact; fairly stiff, but soft; capitulum flat to slightly rounded, often 5-parted.
Distinguishing Characters: One of our most distinctive species, $S$. quinquefarium has three spreading branches per fascicle while other Acutifolia normally have only two. This plus the sharply 5 -ranked branch leaves gives the species an aspect quite similar to $S$. wulfianum. Stem leaves on occasional plants may approach the more lingulate shape of $S$. rubellum, but the latter is a softer plant with often subsecund branch leaves. Their habitats also differ markedly and very rarely, if ever, overlap.

Infraspecific Variation: Infrequently $S$. quinquefarium may lack the 5-ranking in its branch leaves but habitat and stem leaf shape will identify such forms.

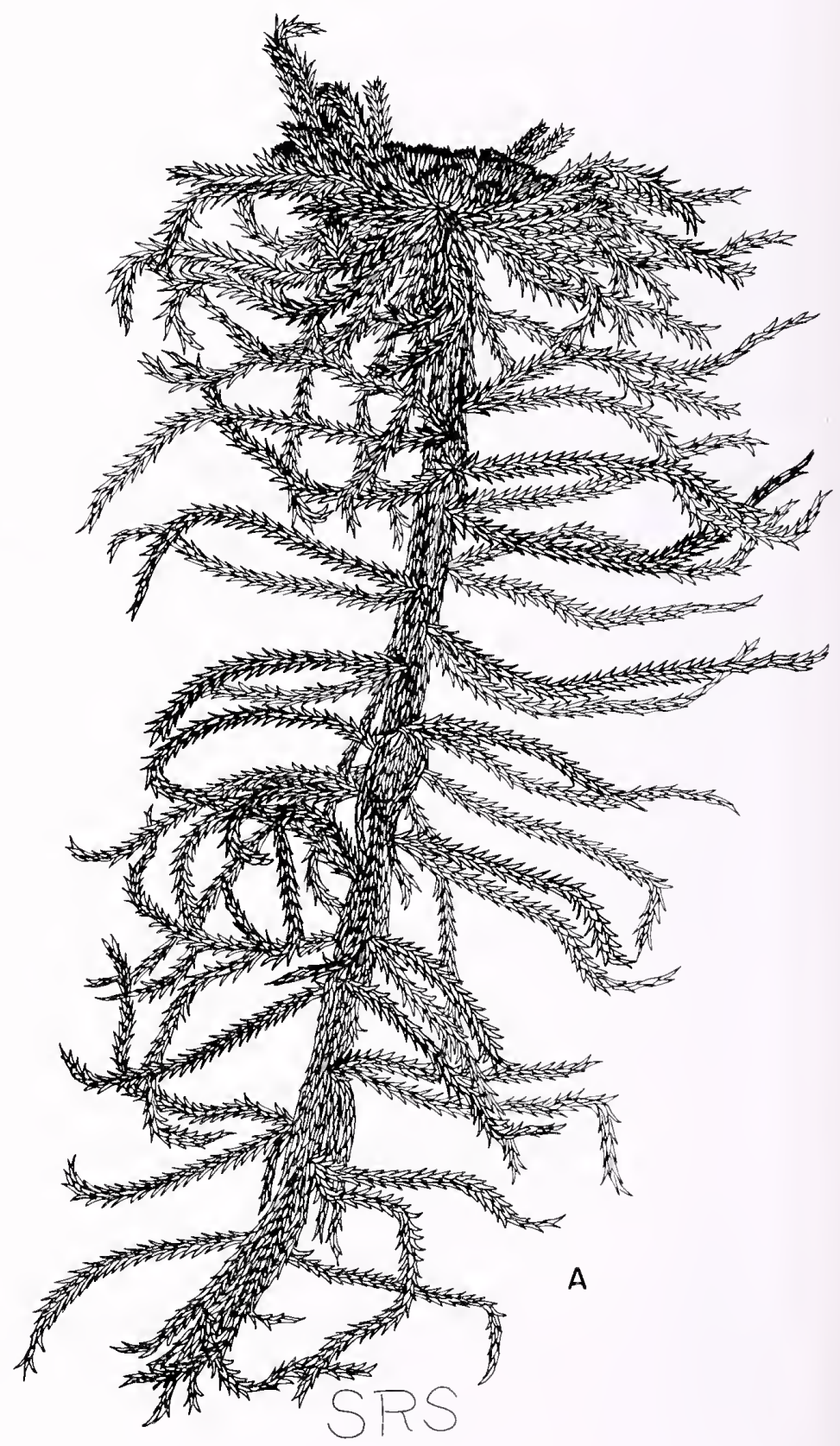


General Distribution: Circumpolar, absent from much of continental interior. In eastern North America from the arctic south to South Carolina, West Virginia, Ohio, Michigan, Illinois, Wisconsin and Minnesota. South of New York rare and restricted to high mountain sites. On the Pacific coast from Alaska south to Washington.

Description: Stem red, yellowish or pale green, the outer stem cortical layer aporose; stem leaves moderate-sized and lingulate, apex broadly rounded (becoming acute in hemiisophyllous forms), border strong and moderately broadened basally; hyaline cells moderatesized, rhombic, 1-2 divided and usually fibrillose; branch leaves small, ovate to ovate-lanceolate, imbricate to moderately lax, 5-ranked and subsecund on at least some branches, involute apically; hyaline cells on the convex surface with numerous round to elliptic pores along the commissures, grading from small round pores at the leaf apex to large elliptic pores basally, the concave surface with large round pores in the lower side regions; pigment purplish-red; plants deep maroon-red to variegated red and yellowishgreen.

Distinguishing Characters: Sphagnum rubellum differs from $S$. nemoreum in its 5-ranked, subsecund branch leaves, lingulate stem leaf with more frequently divided hyaline cells, softer aspect, and deeper pigmentation. Sphagnum nemoreum is also less hydrophytic than S. rubellum and is very rarely found in water level carpets or floating mats. Although its stem leaf shape is also lingulate, S. russowii is easily distinguished by its porose stem cortex (not always present), stiff appearance, fewer stem leaf hyaline cell divisions, and branch leaves neither 5-ranked nor subsecund. Sphagnum warnstorfii often resembles $S$. rubellum but the much smaller and more strongly ringed pores in the branch leaf hyaline cells are always diagnostic for the former. S. warnstorfii also has smaller stem leaves, nonsubsecund and more spreading branch leaves and much more minerotrophic habitat requirements (see also under $S$. andersonianum).

Infraspecific Variation: Coastal forms of S. rubellum, at least in the southern part of its range, are more weakly pigmented and more hemiisophyllous than inland forms.

Note: Following the lead of Andrews (1913), American authors have nearly all recognized $S$. rubellum as var. tenellum under S. capillaceum (= S. nemoreum). Crum (1971) considers this var. tenellum to be the anisophyllous end of a series of forms grading into $S$. capillaceum var. capillaceum and thence into a nearly isophyllous var. tenerum. European workers have usually given $S$. rubellum specific rank. Stem leaf morphology, though a very useful character, must be used

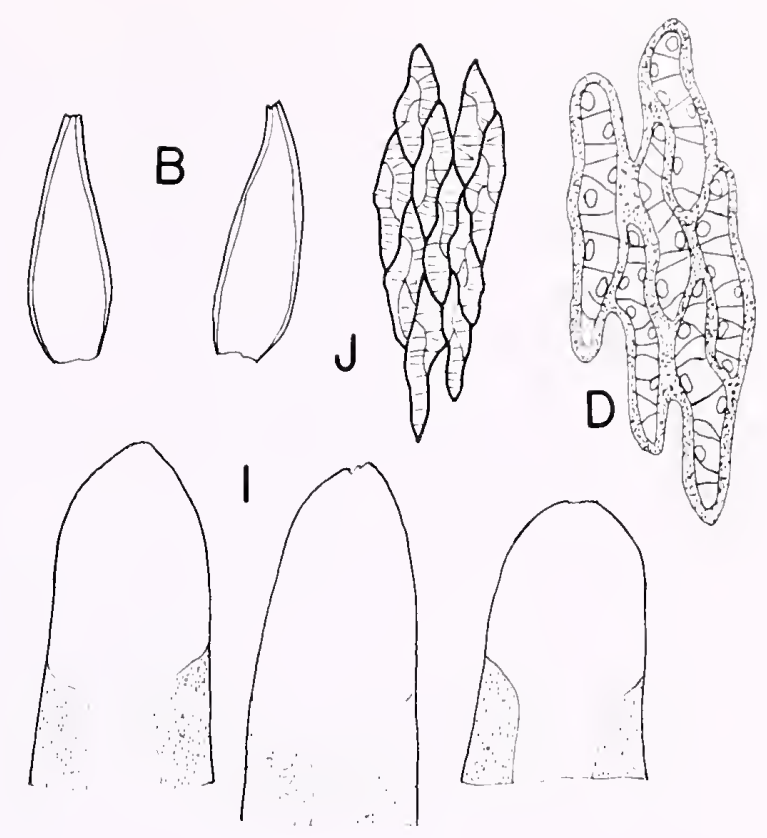

with care in separating Acutifolia species because of the strong tendencies toward hemiisophylly in several species. It is possible, for example, to demonstrate a complete series from anisophyllous through isophyllous forms for S. rubellum alone, as well as for $S$. nemoreum, S. tenerum, S. subtile, S. russowii and others. Since hemiisophyllous stem leaves of many Acutifolia are often indistinguishable, other characters must be employed, such as those summarized in Table 3 for $S$. rubellum, S. nemoreum and S. subtile. Considering morphological as well as ecological and distributional differences, S. rubellum clearly merits specific status. As further evidence, several mixed populations of $S$. rubellum and $S$. nemoreum have been found in New York, and individuals are separable macroscopically in these. Sphagnum rubellum is widespread and, like many other broadly distributed sphagna, exhibits considerable plasticity in form and morphology over its range. Northern plants are smaller, more compact, and have more ovate branch leaves with the apex less involute. Their stem leaves also differ in being smaller, more strongly bordered and efibrillose. Such forms can be difficult to distinguish from S. andersonianum. New York plants of S. rubellum, especially those from Long Island, are often hemiisophyllous, a common phenomenon for many members of section Acutifolia near their southern range limits.

Note: Sphagnum bartlettianum Warnst. is a closely related oceanically distributed Atlantic coastal plain endemic that occurs from Florida to New Jersey. It differs from S. rubellum in having narrower, straight branch leaves and longer, narrower stem leaves, with acute apices and less frequently divided hyaline cells. 


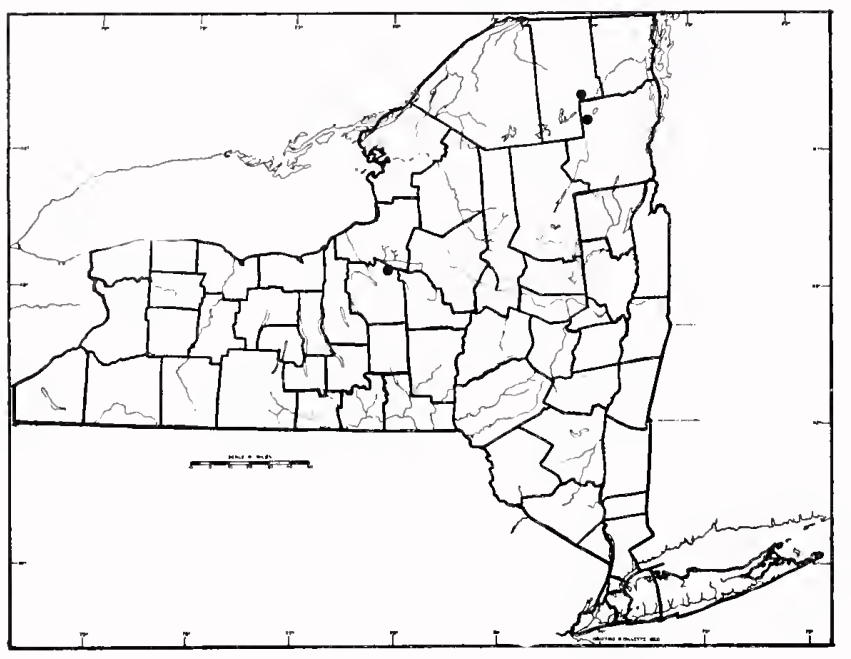

38. Sphagnum andersonianum Andrus

Type Description: Andrus, Bryologist, 83: 60, 1980

Synonym: Sphagnum tenuifolium auct., non-Warnstorf.

Ecology: Weakly minerotrophic. Perhaps our most hydrophytic member of section Acutifola. In New York found in poor fens, often associated with $S$. fallax, $S$. angustifolium and S. rubellum. Forming carpets or low hummocks at or near water level.

Habit: Plants small, soft and slender; capitulum small, with an aspect intermediate between $S$. rubellum and S. tenellum.

General Distribution: From Labrador south to New York.

Description: Stem purplish-red, sometimes paler, the outer stem cortical layer porose or aporose; stem leaves moderate-sized and lingulate, apex rounded, sometimes slightly apiculate, border moderately strong and moderately broadened basally; hyaline cells rhombic, 1-divided and fibrillose or efibrillose; branch leaves small, ovate, laxly imbricate, non-5-ranked, concave and not conspicuously more involute apically, apex dentate, often conspicuously so, with up to 6 teeth; hyaline cells on the convex surface with elliptic pores along the commissures, grading from the smaller pores at the leaf apex to larger pores basally, the concave surface with large round pores in the lower side-regions; pigment purplish-red; plants pale pink, pale purplish-red or deep purplish-red.

Distinguishing Characters: The small, ovate, concave branch leaves give $S$. andersonianum a very soft, slender and delicate $S$. tenellum-like appearance. Sphagnum andersonianum is the only Acutifolia species that has most branch fascicles with one hanging branch. The remaining species all have fascicles with two hanging branches. Sphagnum rubellum, however,

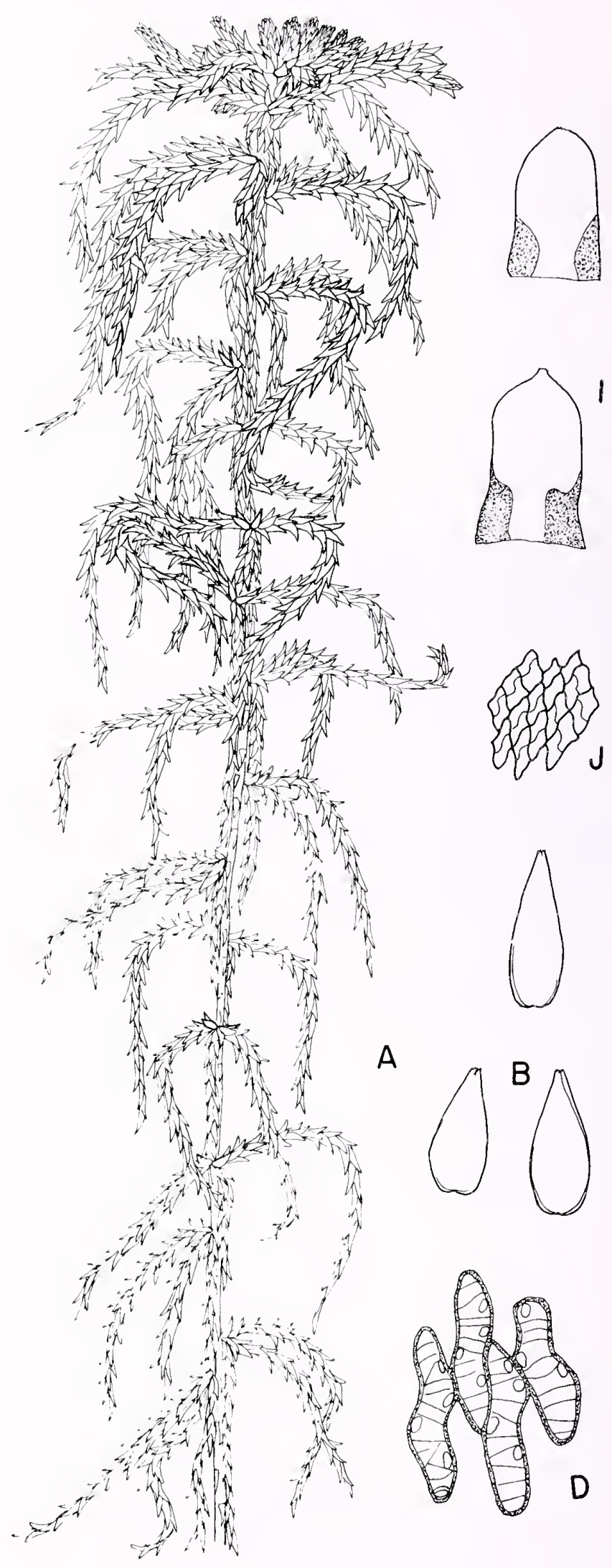


in more northern and humid portions of its range, bears a striking resemblance to a robust $S$. andersonianum. Sphagnum rubellum from Risley Moss in England, the type locality, has the same ovate and noninvolute-tipped branch leaves that characterize $S$. andersonianum. Moreover, the stem leaves are also quite similar. The Risley Moss, S. rubellum, does, however, have two hanging branches per fascicle. There can be no doubt that $S$. andersonianum is specifically distinct from $S$. rubellum, since they are clearly separable when associated. A mixed collection is known. When growing together, S. andersonianum is softer, slenderer and paler than S. rubellum.

TABLE 3. COMPARISON OF SPHAGNUM RUBELLUM, S. SUBTILE, AND S. NEMOREUM

\section{Character}

Stem leaf shape

Stem leaf hyaline cells

Stem leaf

Branch leaves

Capitulum

Hemiisophyllous forms

Ecology

Distribution

\section{S. rubellum}

lingulate to lingulatetriangular

rhombic, moderatesized, 1-3 septate, often fibrillose

strong, moderately broadened basally

5-ranked, usually subsecund

flat-topped to slightly rounded, often with 5 parted stellate appearance

fairly common, developing elliptic pores on outer surface

ombrotrophic, hydrophytic, in open mires, forming carpets or occasionally hummocks

suboceanic tendencies, in $\mathrm{N} . \mathrm{Y}$. common upstate and on Long Island
S. subtile

triangular-lingulate to lingulate

rhombic, small $1(2)$ septate, usually efibrillose

very strong, greatly broadened basally

5-ranked in coastal forms not 5-ranked in inland forms, not subsecund

flat-topped, neither hemispherical nor markedly stellate in appearance

less common, often developing large membrane gaps on outer surface

weakly minerotrophic, hygrophytic, wet coniferous forests or pond margins, forming carpets or rarely hummocks

suboceanic tendencies?, in N.Y. common upstate and on Long Island
S. nemoreum

lingulate-triangular

S-shaped, moderatesized, 0-1 septate, usually fibrillose and often porose

strong, moderately broadened basally not 5-ranked, not subsecund

hemispherical "pompom" appearance

very common, developing elliptic pores on outer surface

ombrotrophic to weakly minerotrophic, hygrophytic, open or heathshrub mires, also wooded mires, forming hummocks

not suboceanic, in N.Y. common upstate and absent on Long Island 


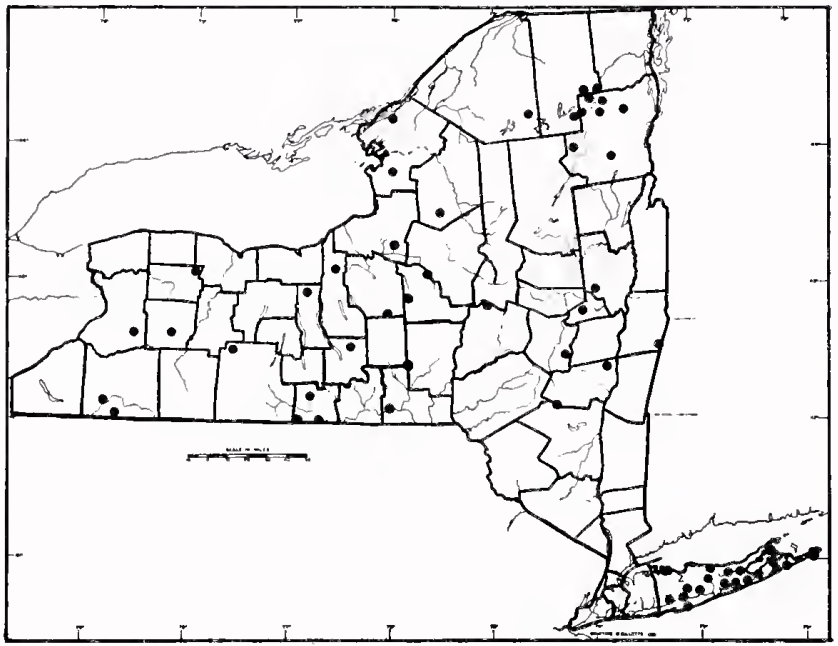

39. Sphagnum subtile (Russow) Warnst.

Type Description: Warnstorf, Krypt. Brandenburg, 1:409, 428, 1903.

Ecology: Moderately minerotrophic. Hygrophytic. On damp coniferous humus in forested mires, often associated with $S$. girgensohnii, S. centrale, and $S$. russowii. Also at margins of mires and ponds. Near the coast occurring in open mires.

Habit: Plants small to occasionally moderate-sized; slender and stiff; capitulum moderate-sized, \pm flattopped; aspect similar to $S$. warnstorfii or slender forms of $S$. nemoreum. Forming carpets and low hummocks.

General Distribution: Amphiatlantic and east Pacific. From Labrador to New Jersey and inland. Near the Great Lakes in Quebec, New York, Ontario, Ohio, Indiana, Illinois, Wisconsin, Michigan and Minnesota. South through the Appalachian Mountains to North Carolina. Also near the coast in British Columbia and Washington.

Description: Stem green to red with the outer stem cortical layer aporose; stem leaves small, triangularlingulate to lingulate, apex broadly rounded and occasionally \pm pointed, border very strong and much broadened basally; hyaline cells rhomboidal, normally efibrillose, and mostly once-divided; branch leaves small, ovate-lanceolate, imbricate to moderately lax, not 5-ranked (5-ranked in coastal forms) and moderately involute apically; hyaline cells on the convex surface with numerous round to elliptic pores, along the commissures grading from small pores at the leaf apex to large pores at the leaf base, the concave surface with large round pores in the lower side-regions; pigment purplish-red; plants green or weakly pigmented, deep red forms sometimes found.

Distinguishing Characters: Sphagnum subtile is best recognized by its distinctive stem leaf with a strong border, greatly broadened basally.

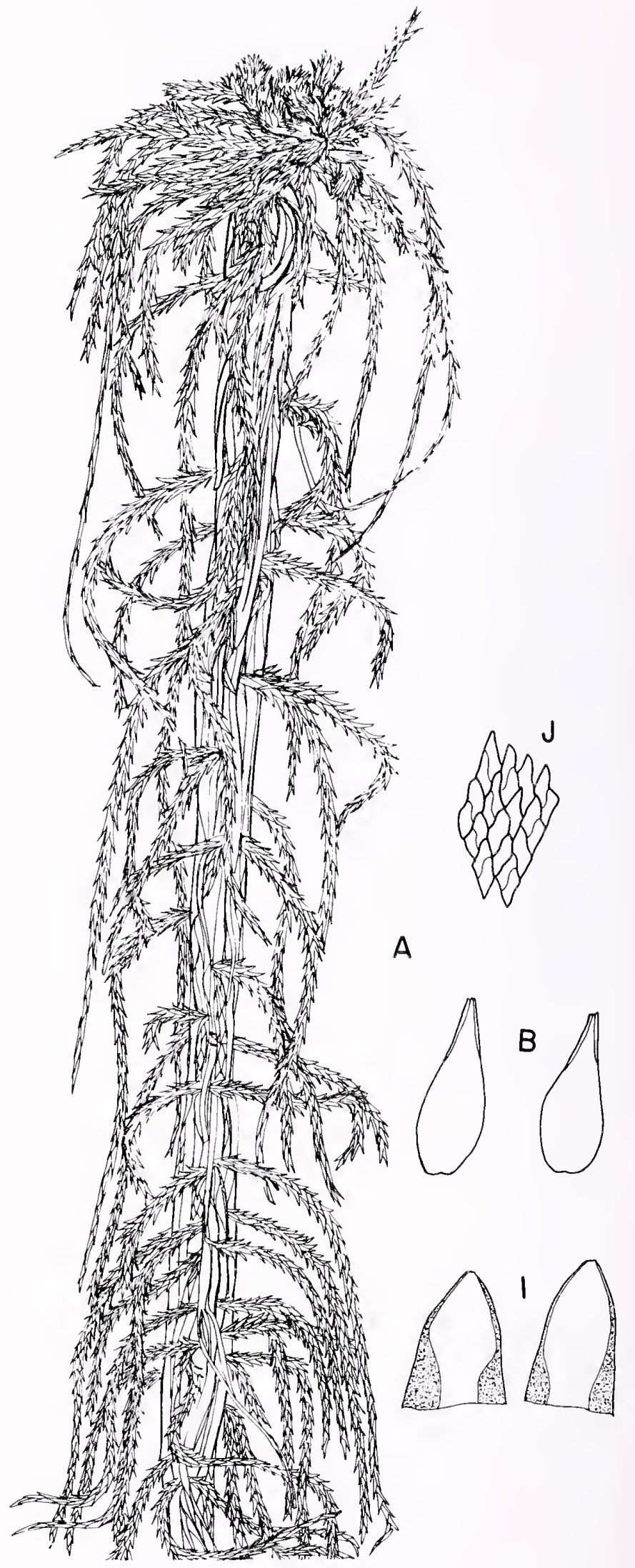




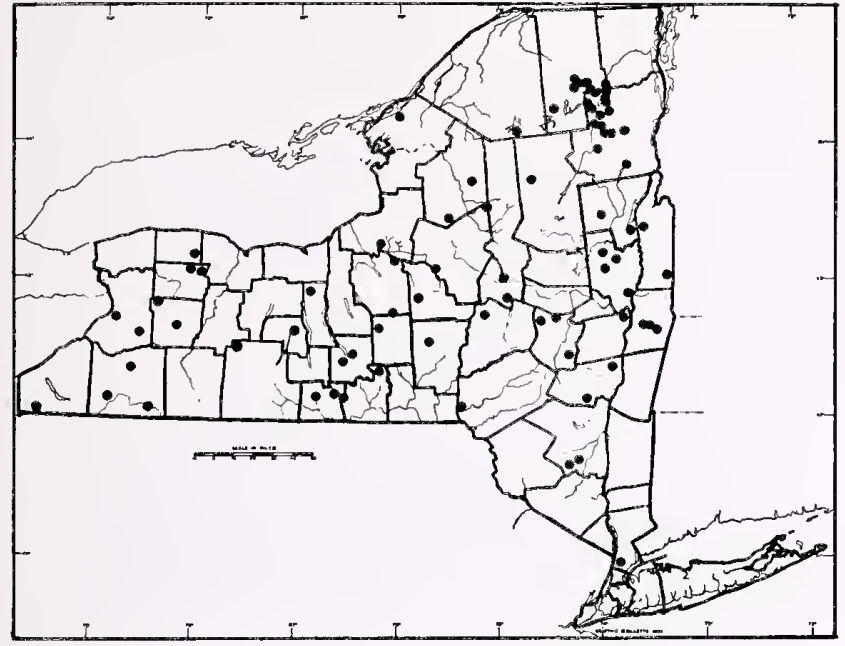

40. Sphagnum nemoreum Scop.

Type Description: Scopoli, Fl. Carn. ed. 2, p. 305, 1772.

Synonyms: S. capillifolium (Ehrh.) Hedwig, S. capillaceum (Weiss) Schrank, S. acutifolium Ehrh. ex Schrad., S. tenerum auct., non Sull. \& Lesq.

Ecology: Ombrotrophic to weakly minerotrophic. Weakly hygrophytic. This species is found in a wide variety of acidic habitats. Most common and abundant in ombrotrophic heath vegetation associated with $S$. magellanicum, S. fallax, $S$, angustifolium, $S$. fuscum, S. rubellum, Polytrichum juniperinum and $P$. commune. Also abundant forming dense mats over wet, acidic rocks and peat, especially at higher elevations. Less frequent in wooded fen vegetation. Like S. fuscum and S. magellanicum, S. nemoreum seems to appear as an occasional component in suitably acidic microsites in an exceptionally wide range of mire types (see under $S$. fuscum).

Habit: Plants small to moderately large, compact to fairly slender, normally stiff and erect; capitulum typically hemispherical, with the aspect of a pompom. Forming low to high hummocks.

General Distribution: Circumpolar (Isoviita 1966). In North America from the arctic south to North Carolina, West Virginia, Indiana, Illinois, Wisconsin, Minnesota, Kansas, Colorado, Montana and Washington. In its eastern North American distribution becoming restricted to high elevations in the Appalachians, south of New York. Unknown from the coastal plain on Long Island and south.

Description: Stems green to red, the outer stem cortical layer aporose or (rarely) with a few scattered small pores; stem leaves moderate-sized, lingulate-triangular and \pm involute apically to a narrow, rounded and weakly toothed apex, border moderately strong and moderately broadened basally; hyaline cells S-shaped,

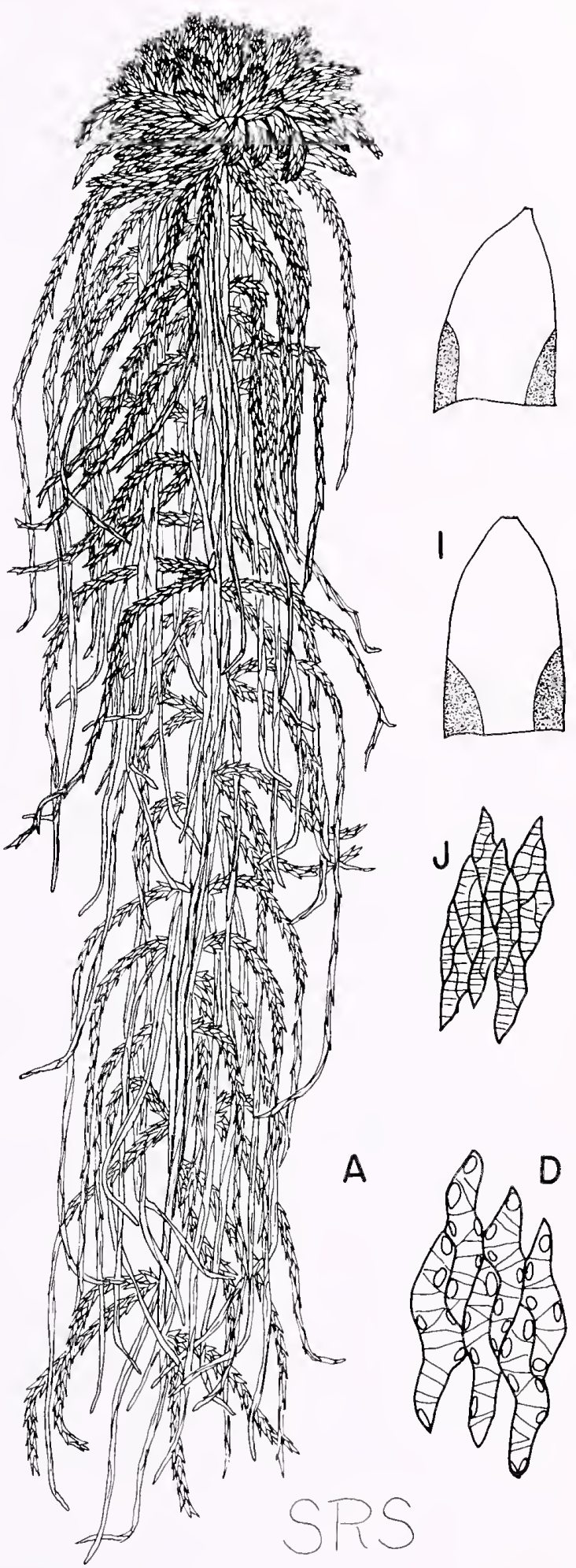


often 1-divided, fibrillose at least at the leaf apex and frequently porose as well; branch leaves small and ovate-lanceolate, imbricate to moderately spreading, not 5-ranked, strongly involute apically; hyaline cells on the convex surface with elliptic pores along the commissures, grading from moderate-sized pores at the leaf apex to large pores at the leaf base, the concave surface with large round pores in the lower side regions; pigment purplish-red; plants red or mottled red and green, green forms frequent.

Distinguishing Characters: See under S. subtile, S. rubellum and $S$. tenerum for distinctions from those species. Hemiisophyllous and isophyllous forms of $S$. russotcii are often difficult or impossible to distinguish from $S$. nemoreum. If present, the large stem cortical pores of $S$. russowii will distinguish it. Sphagnum russowii also usually has numerous large round pores near the branch leaf apex on the concave surface while $S$. nemoreum in the same position either lacks pores or has a few small oval pores in the cell ends. Near the

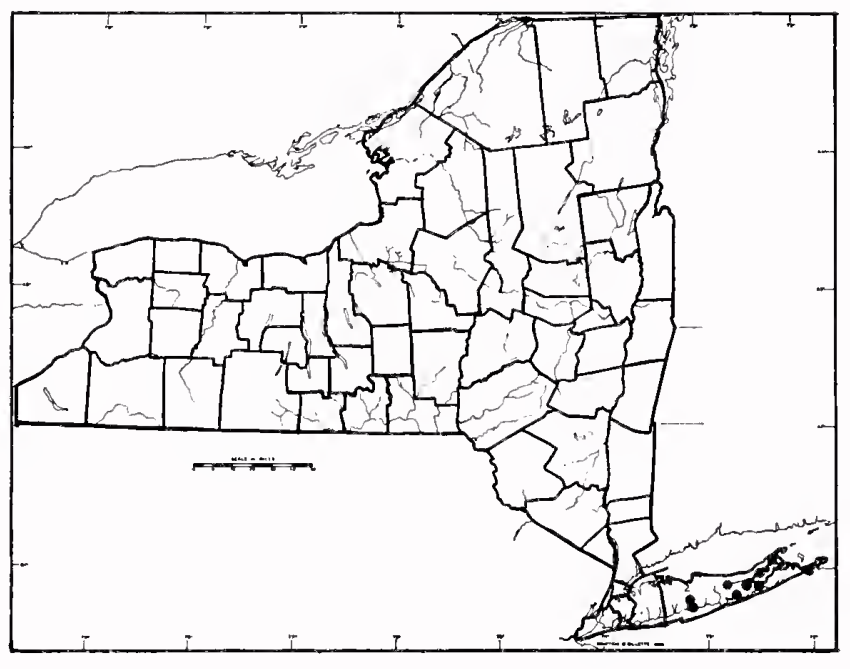

41. Sphagnum tenerum Sull. \& Lesq.

Type Description: Sullivant in Gray, Man. Bot. ed. 2, p. $611,1856$.

Synonym: S. tenerum Warnst.

Ecology: Weakly minerotrophic. Weakly hygrophytic. Occurring on damp sand and thin humus especially at pond margins. Often found in sites that are periodically dessicated.

Habit: Plants \pm robust; weak-stemmed and compact; capitulum normally hemispherical, with the aspect of a large, turgid-branched, S. nemoreum. Typically forming low to tall hummocks.

General Distibution: North American Atlantic coast endemic. Near the coast from Massachusetts to Florida and Alabama and occasional in mountainous areas in Tennessee, South Carolina and Alabama. apex on the convex branch leaf surface, S. russowii has smaller, rounder and more numerous pores than $S$. nemoreum.

Note: Some treatments have used the epithet tenerum at the varietal level to refer to hemiisophyllous and isophyllous forms of S. nemoreum (Nyholm 1969, Crum 1976). This is an incorrect application of the epithet tenerum, which refers to a distinct taxon; it also seems of questionable value to give varietal status to what seems clearly to be only an environmental modification. The epithets $S$. nemoreum, S. capillaceum, and $S$. capillifolium, are all in common usage for this species. The nomenclatural difficulties are summarized in Isoviita (1966) and Crum (1975). The policy in this treatment is to use the widely known $S$. nemoreum until such time as the type of $S$. capillifolium can be examined by a bryologist thoroughly familiar with the Acutifolia group.

Importance: A major peat former in boreal mires of suboceanic distribution.
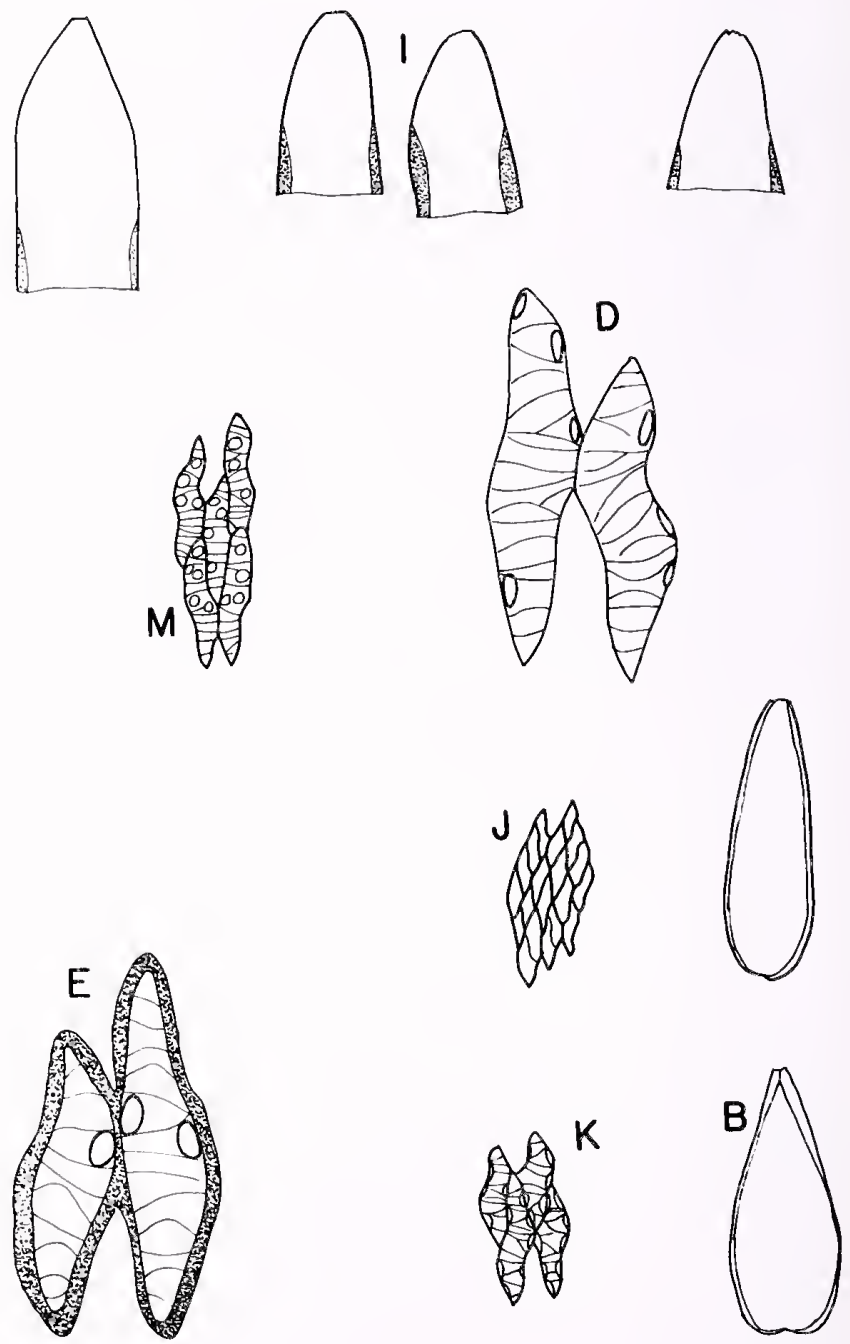
Description: Stem pale yellow-green to pink, the outer stem cortical layer aporose; stem leaves moderatesized to large, elongate triangular to elongate triangular-ovate and \pm involute above to the conspicuously toothed apex, border narrow and little broadened basally; hyaline cells large, narrowly rhombic to $\mathrm{S}$ shaped, \pm 1 -divided, fibrillose and usually porose (hemiisophyllous forms very common); branch leaves large, ovate, tightly imbricate, non-5-ranked and weakly involute toward the relatively broad and conspicuously toothed apex; hyaline cells on the convex surface with round to elliptic pores along the commissures, grading from moderate-sized pores at the leaf apex to large pores basally, the concave surface with large round pores throughout; pigment purplish-red; plants typically mottled pale yellow-green and purplish-red.

Distinguishing Characters: Although their ranges scarcely overlap (probably only in coastal Massachusetts or Connecticut), S. tenerum is frequently confused with hemiisophyllous forms of $S$. nemoreum. Numerous points of difference exist, however, as summarized in Table 4 . The separation of $S$. tenerum from hemiisophyllous and isophyllous forms of $S$. nemoreum is an undeniably vexing problem. However, using the broad range of characters in Table 4 , all but the most aberrant forms of species should be positively identifiable. Similar problems can occur with hemiisophyllous forms of $S$. russowii, which, unlike $S$. nemoreum, does overlap S. tenerum in New York. Sphagnum russowii, however, is much slenderer and less robust in all its parts.

Infraspecific Variation: Andrews (1913) utilized the greater free convexity of the branch leaf chlorophyll cells on the outer leaf surface ("usually more than one half their diameter") as a key character to separate $S$. tenerum, S. tabulare ( $=S$. molle), and S. plumulosum (sensu lato) from related members of the Acutifolia. Unfortunately, hyaline cell convexity is not an especially constant character, and its usage as a major key character is of dubious validity, since $S$. nemoreum, $S$. fuscum and other Acutifolia develop abnormally high convexities under some conditions. The converse is true for S. tenerum and S. plumulosum sensu lato.

Note: Due to its superficial similarity to $S$. nemoreum, $S$. tenerum has long been one of our most misunderstood sphagna. A number of bryologists (Warnstorf 1899, 1911, Roth, 1906, Sherrin 1927, Lange 1955, Malmer 1966) have reported S. tenerum for Europe, far outside its normal range. Others (Zerow 1928, Andrews 1958, Ronning 1958, Isoviita 1966) have recognized that such reports were based upon modifications of $S$. nemoreum.

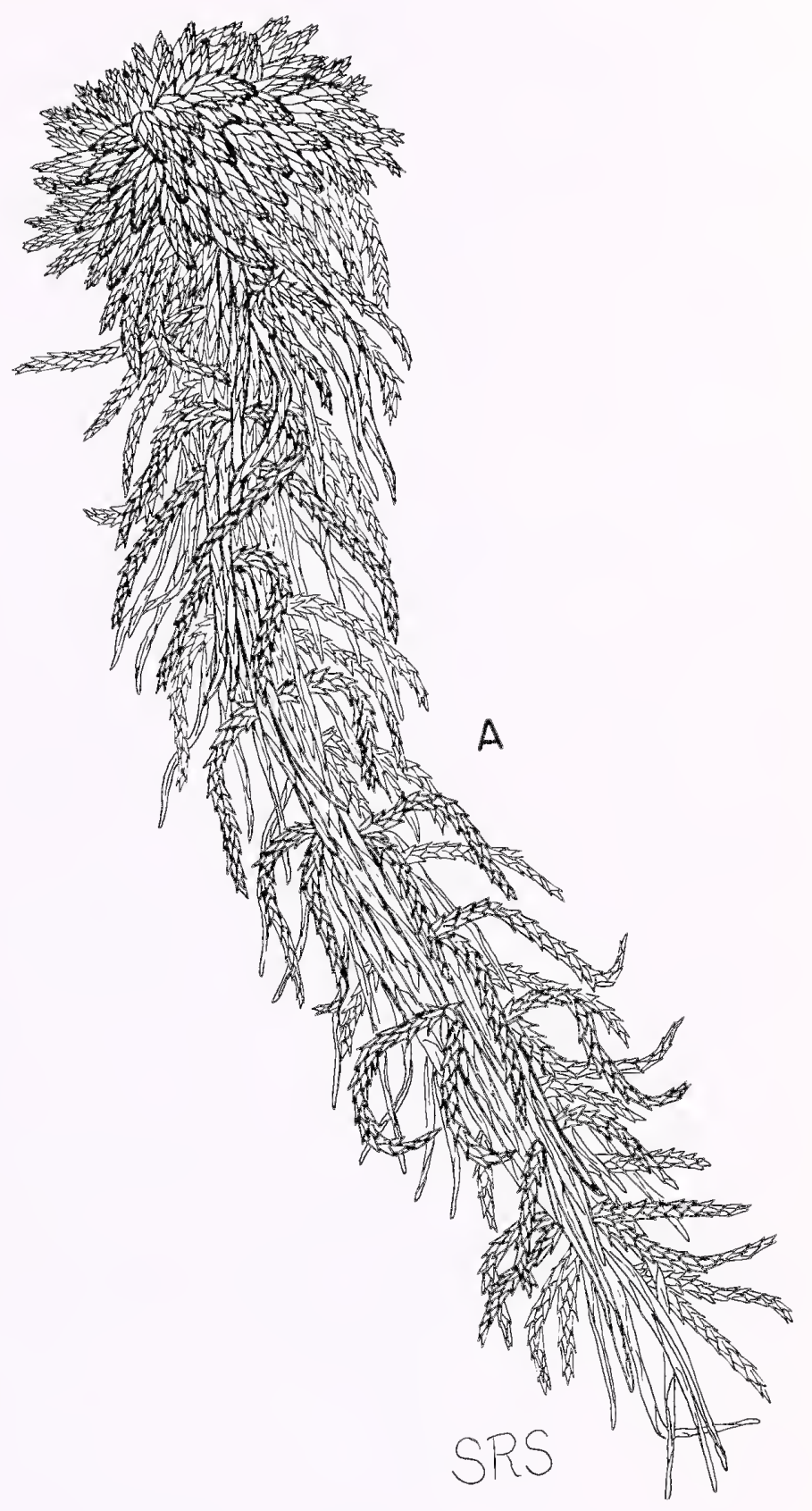


TABLE 4

COMPARISON OF SPHAGNUM TENERUM AND S. NEMOREUM

\section{Character}

Size and aspect

Stem leaf *

shape

areolation

hyaline cells

porosity

hemiisophyllous and isophyllous

forms

border

apex

Branch leaves

shape

apex

areolation

large round pores on concave

surface

arrangement
S. tenerum

\pm robust

elongate-triangular to elongate

triangular-ovate

very lax, leaf with a very open texture

large, elongate rhombic to S-

shaped

usually porose in upper $1 / 2$ and often throughout

hemiisophyllous forms very common, isophyllous forms fairly common

narrow and little broadened basally

strongly toothed

ovate

weakly involute, strongly toothed

very lax

numerous throughout

tightly imbricate, branches with a turgid appearance

\section{S. nemoreum}

\pm moderate-sized

triangular-lingulate

not especially lax, leaf texture not especially open

S-shaped

usually porose apically, infrequently throughout

hemiisophyllous forms frequent, isophyllous forms rare

moderately strong and moderately broadened basally

weakly toothed

ovate-lanceolate

strongly involute, weakly toothed

not unusually lax

in lower side regions only

loosely imbricate, branches with a slender appearance

* Stem leaf characterizations are based upon the forms most frequently encountered. In the case of S. tenerum, hemiisophyllous forms are most frequent. Anisophyllous forms of $S$. tenerum are found, however, and stem leaves of such forms are pictured in the accompanying figures. 


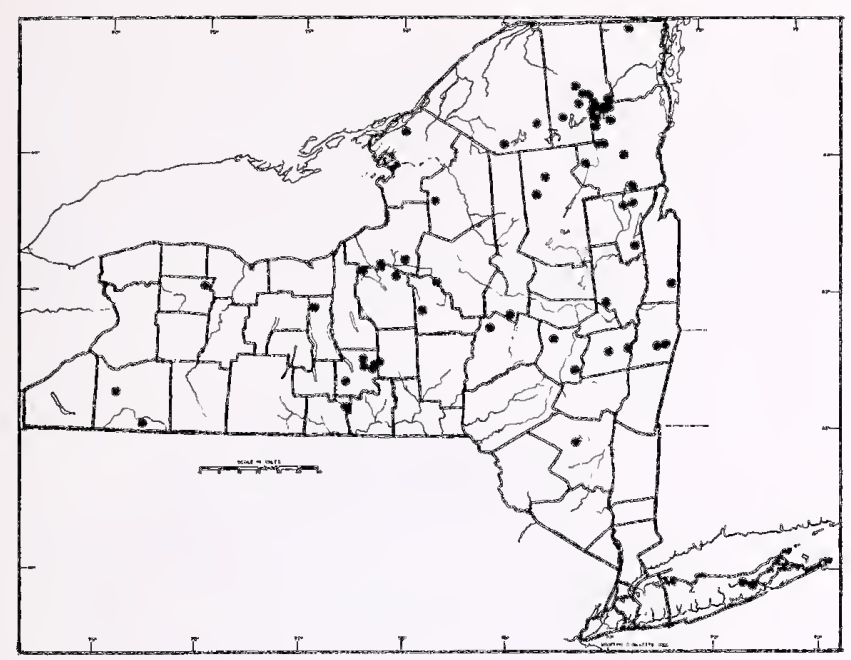

42. Sphagnum fuscum (Schimp.) Klinggr.

Type Description: Klinggraff, Schrift. Phys. Oek. Ges. Köningsberg 13(1): 4, 1872.

Synonym: S. tenuifolium Warnst.

Ecology: Ombrotrophic to weakly minerotrophic. Weakly hygrophytic. Widespread in ombrotrophic mires, associated with $S$. rubellum, $S$. nemoreum, $S$. magellanicum, S. fallax and S. angustifolium. With these same species plus $S$. papillosum on poor fen floating mats. Also common on alpine mountain summits. As in the ecologically similar S. nemoreum, the weakly hygrophytic nature of $S$. fuscum often allows it to survive wherever suitably acidic microsites are available (often among other already established sphagna). Sphagnum fuscum is even found in rich fens, where the growth of such species as $S$. warnstorfii and S. teres may, through cation exchange, create a much lower $\mathrm{pH}$ value within the colonies than is found in the ambient water.

Habit: Plants small, slender, stiff and often compact, capitulum small and flat. Typically forming low to tall hummocks.

General Distribution: Circumpolar, with slightly continental tendencies. In North America from the arctic south to Virginia, West Virginia, lllinois, Wisconsin, Minnesota, Colorado, Utah, Idaho and Oregon. Rare south of New York and confined to high elevations.

Description: Stem dark reddish-brown with the outer stem cortical layer aporose; stem leaves lingulate, apex rounded and entire, sometimes slightly mucronate or denticulate, border strong and greatly broadened basally; hyaline cells rhombic, 1-2 divided, and efibrillose, branch leaves small, ovate-lanceolate, imbricate to slightly spreading, only very rarely 5ranked, strongly involute apically; hyaline cells on the convex surface with round to elliptic pores along the

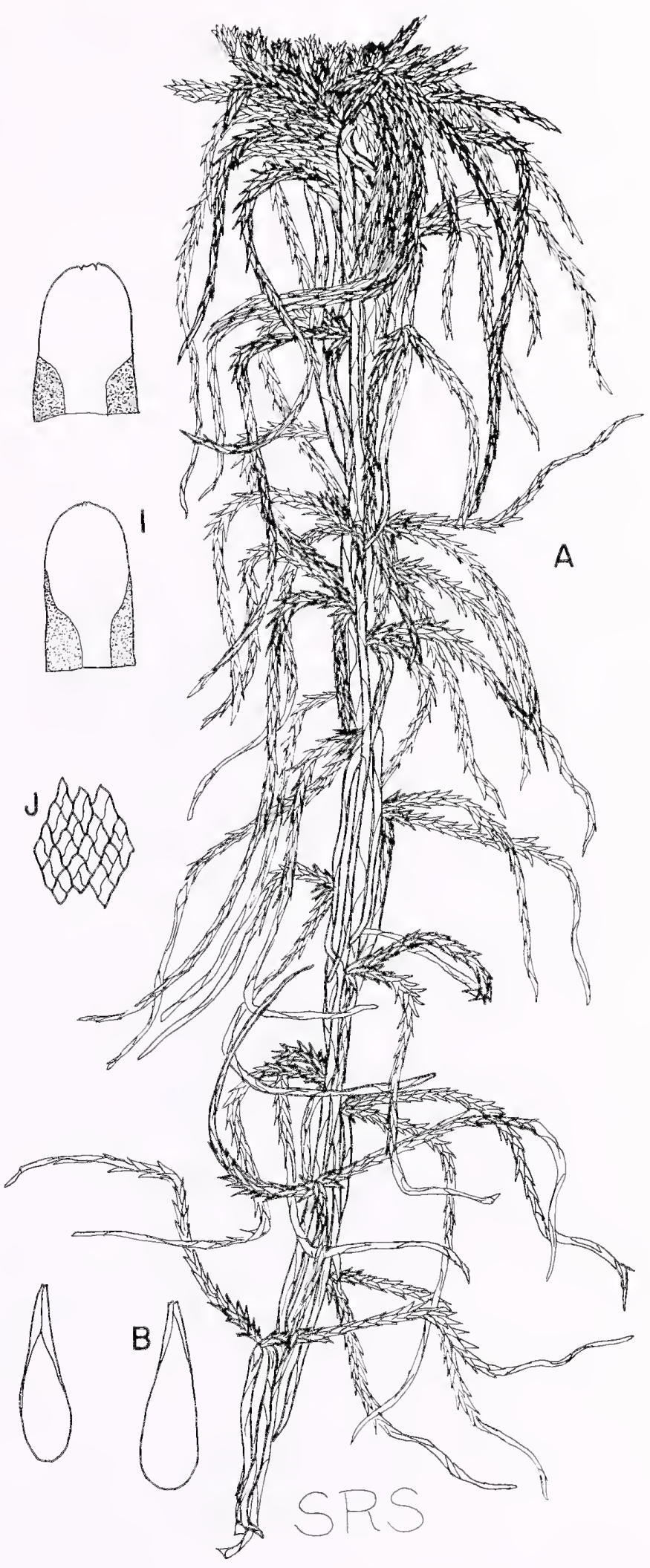


commissures, grading from small pores at the leaf apex to large pores at the leaf base, the concave surface with large round pores in the lower side-regions; pigment brown; plants typically deep, reddish-brown, green forms infrequent.

Distinguishing Characters: As our only small brown member of the Acutifolia, S. fuscum is usually easily recognized. Sphagnum subfulvum is a more robust and softer plant that has larger stem leaves with apices mostly right-angle pointed at the tip.

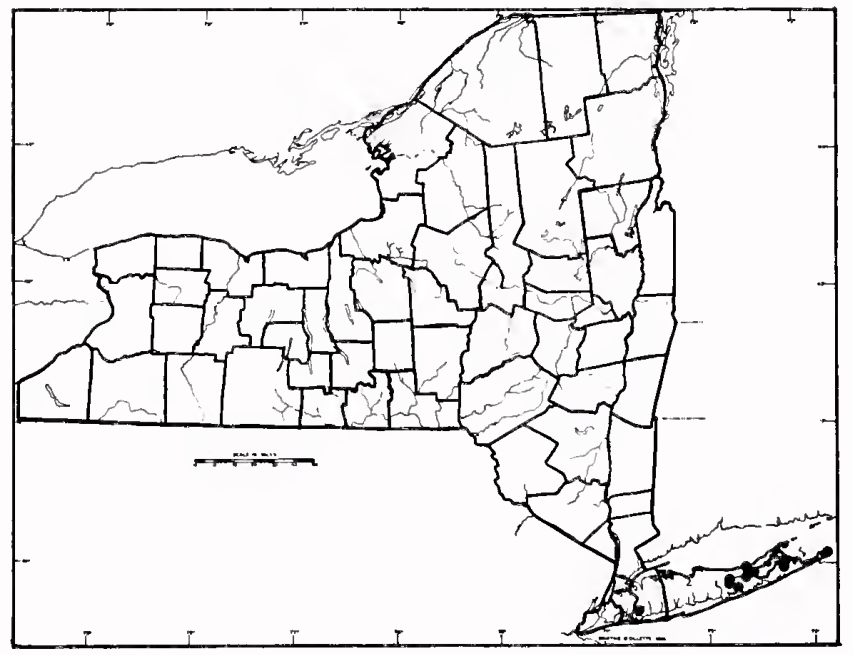

43. Sphagnum flavicomans (Card.) Warnst.

Type Description: Warnstorf, Sphagn. Univ., p. 79, 1911.

Ecology: Ombrotrophic to weakly minerotrophic. Hygrophytic. On Long Island forming hummocks at pond margins and in poor fens where some shade is available. Common associates are $S$. papillosum, $S$. rubellum, S. tenerum, S. torreyanum and S. cuspidatum. Also occasionally forming carpets in wet woods. From Maine northward also found in ombrotrophic habitats (Osvald, 1940).

Habit: Plants are normally robust, sometimes moderate-sized, stiff and erect; capitulum large and typically hemispherical with the aspect of a very large $S$. fuscum. Principally a hummock former.

General Distribution: A North American Atlantic coastal plain endemic, found near the coast from Newfoundland to New Jersey.

Description: Stem dark reddish-brown with the outer stem cortical layer aporose; stem leaves large, narrow lingulate-triangular, apex right-angled to apiculate, border moderately strong and greatly broadened basally; hyaline cells rhombic, 1-divided, and normally fibrillose toward the leaf apex; branch leaves large, ovate-lanceolate, imbricate, non-5-ranked, strongly involute apically; hyaline cells on the convex surface
Importance: A major peat former in boreal mires, especially raised bogs. Probably the most important peat-forming Sphagnum species on a worldwide basis. Note: Previous work (Andrus, 1974) has recognized S. tenuifolium as a distinct species. Reexamination of the type has caused me to agree with Andrews (1913) that it is identical with $S$. fuscum.

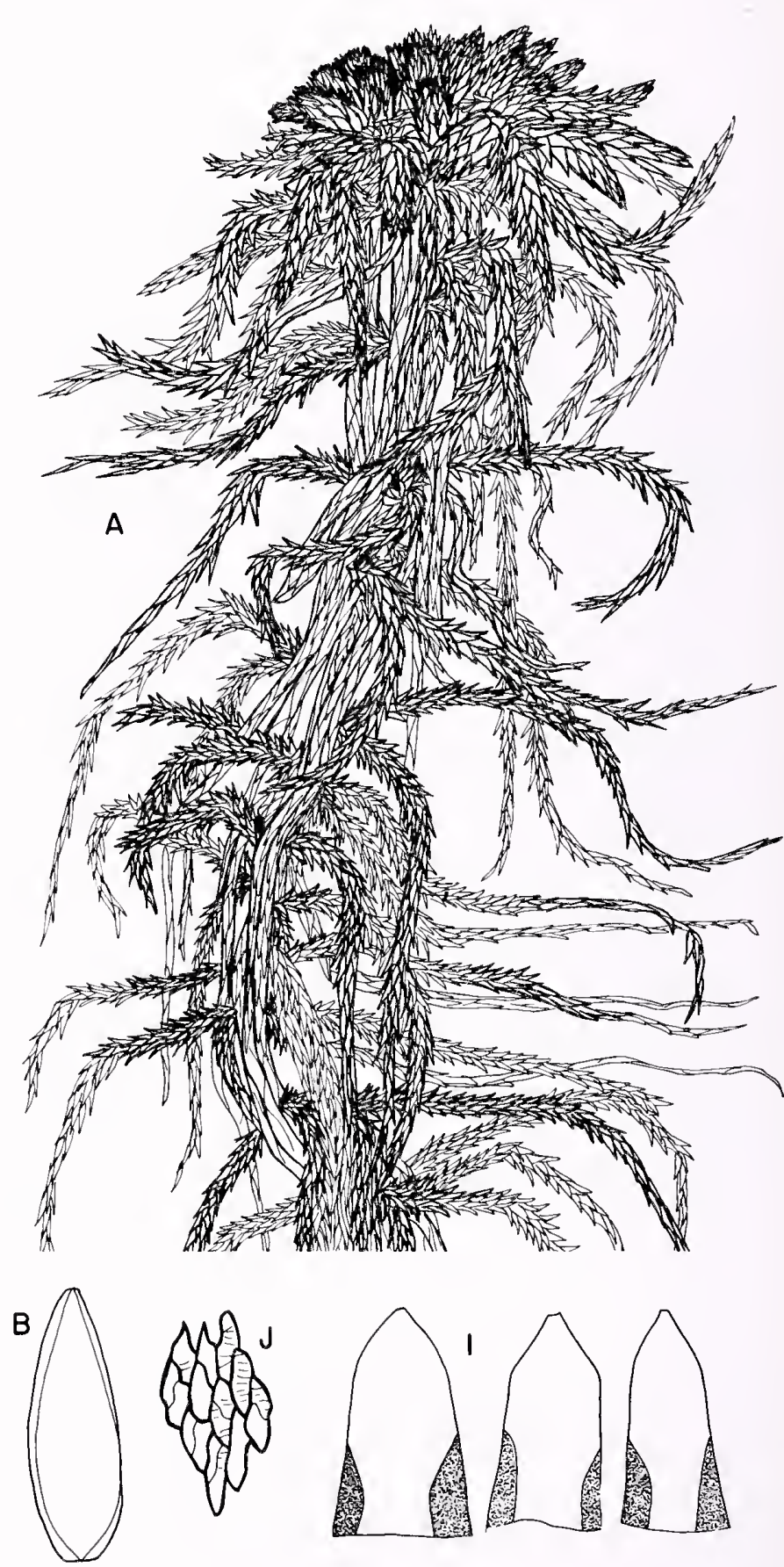


with elliptic pores along the commissures, grading from moderate-sized pores at the leaf apex to large pores at the leaf base, the concave surface with large round pores in the lower side-regions; pigment brown; plants usually deep brown, frequently with a faint metallic purplish lustre when dry.

Distinguishing Characters: Because of its distinctive aspect, like a greatly enlarged S. fuscum. S. flavicomans is usually readily recognized both fresh and dried. Our only other large, brown member of the

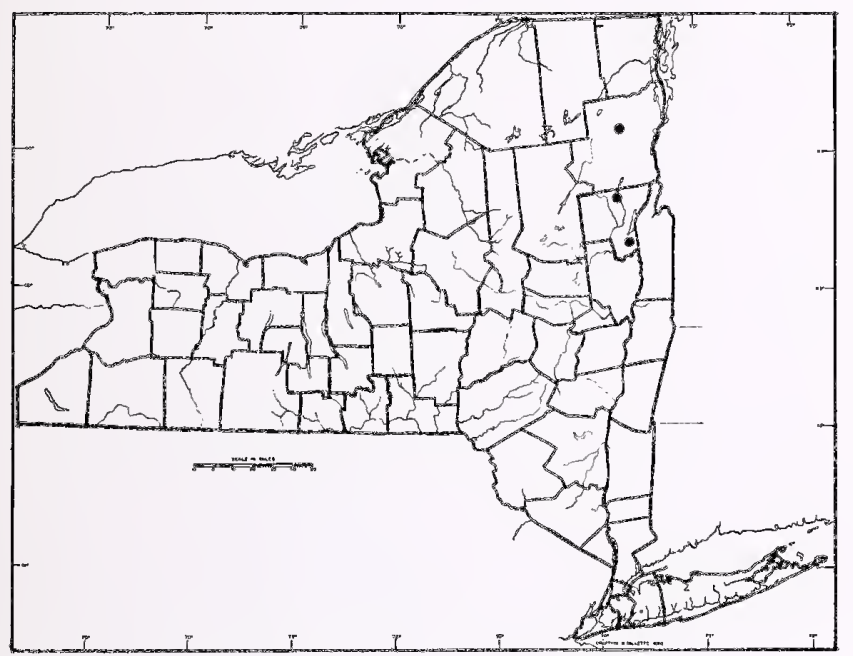

\section{Sphagnum subfulvum Sjörs}

Type Description: Sjörs, Svensk. Bot. Tidskr. 38:413, 1944.

Synonym: S. nitidum Warnst. (nomen nudum?)

Ecology: Minerotrophic and hygrophytic. Details of ecology unclear because of rarity; has been found in medium and rich fens of shrubby and wooded character; its most prominent associates in New York are the more minerotrophic sphagna-S, warnstorfii, S. centrale, $S$. contortum, $S$. subsecundum and $S$. teres.

Habit: Plants moderate-sized, infrequently robust, usually soft and lax, sometimes moderately stiff; capitulum typically enlarged and flattened. A hummock former.

General Distribution: Circumpolar. In eastem North America from the arctic south to New York, Michiw gan, and Minnesota. Rare south of Canada. Also in Alaska and adjacent Canada, Europe and Japan.

Description: Stem yellowish-brown to dark brown with the outer stem cortical layer aporose; stem leaves moderate-sized, broadly lingulate to broadly lingulatetriangular, apex broadly rounded, obtusely angled, or rarely apiculate, border very strong and much broadened basally; hyaline cells rhombic, \pm 1 -divided
Acutifolia, S. subfulvum, is a far northern species most unlikely to be found in New York's coastal area and probably overlaping $S$. flavicomans distributionally only in Newfoundland. Sphagnum flavicomans is, however, easily distinguished from S. subfulvum by its much stiffer growth habit and more ombrotrophic habitat requirements. Its stem leaves are also larger, more lingulate-triangular and more consistently fibrillose toward the apex than S. subfulvum.

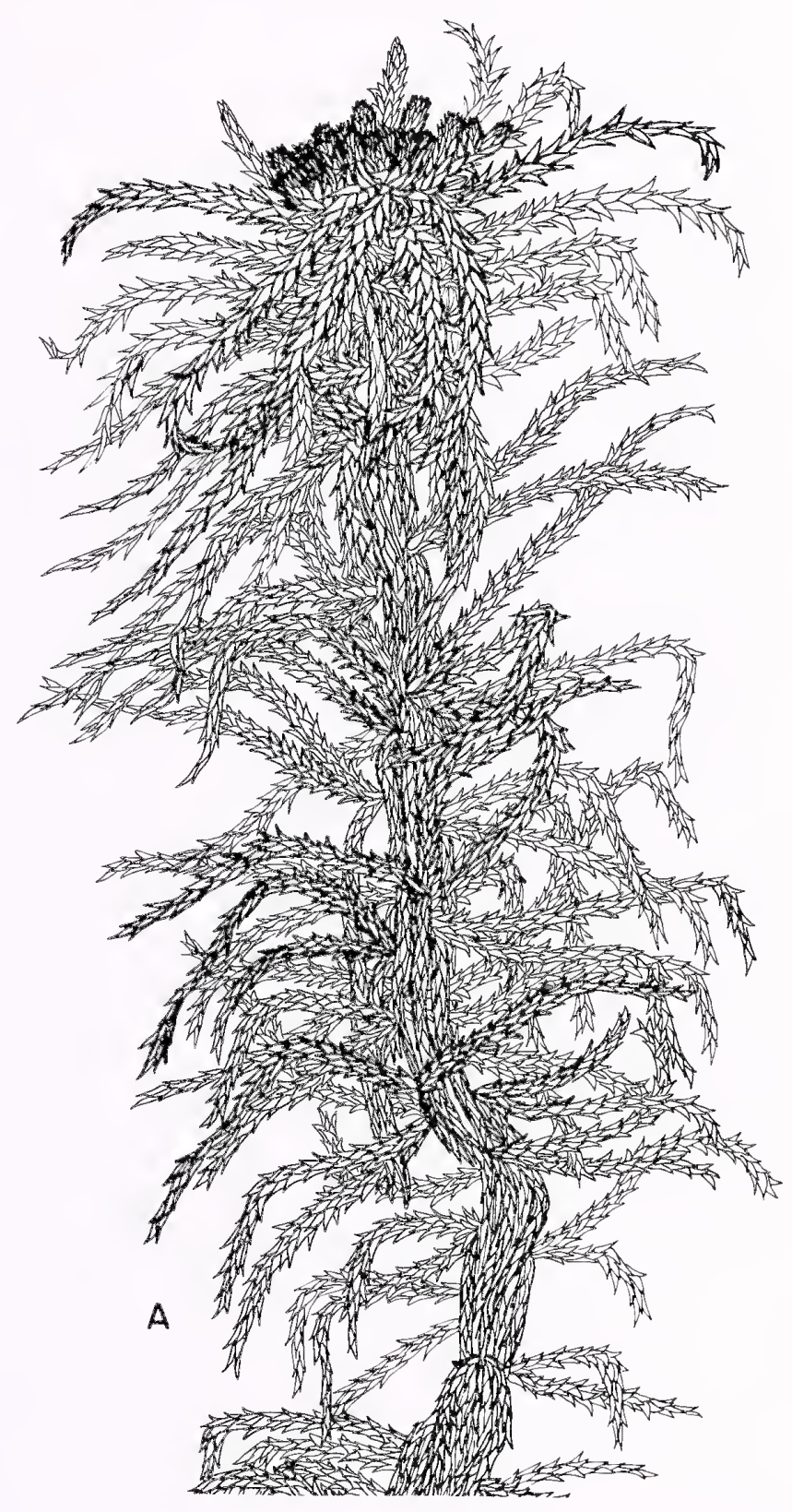


and mostly efibrillose; branch leaves moderate-sized, ovate, imbricate or slightly lax, non-5-ranked and involute apically; hyaline cells on the convex surface with elliptic pores along the commissures, grading from moderate-sized pores at the leaf apex to large pores basally; the concave surface with large round pores in the lower side-regions; pigment brown; plants green to goldish-brown, unshaded plants often with reddishpurple, spreading branches and a purplish metallic sheen when dry.

Distinguishing Characters: Sphagnum flavicomans is easily distinguished by its stiffer aspect and long, more sharply pointed stem leaves. Typical open-growing forms are a much darker brown than S. subfulvum. Extremely robust hydrophytic modifications of $S$. fuscum are occasionally confusing, but these always have characteristic, lingulate stem leaves, while on $S$. subfulvum at least some are lingulate-triangular.

Note: In northern Europe, the separation of S. subnitens and S. subfulvum often presents considerable difficulty. For eastern North America such difficulties are not encountered as S. subnitens is apparently absent. A major reason for the confusion of S. subfulvum and S. subnitens lies in the original Sjörs (1944) description of the former species. He asserts that a major distinguishing character is the purple pigment present in S. subnitens and absent in S. subfulvum. In North American material, at least, this is inaccurate, as open grown plants of $S$. subfulvum, especially those on the sides of hummocks, often develop a reddish-purple coloration in the spreading branches. As dried specimens age, this coloration becomes even more noticeably purplish or bluish and plants that seemed only brown when collected can become quite strongly purple to blue-tinged in the herbarium. The deeper coloration that develops with age is not the red-purple pigment, which fades with time, but apparently a structural color. Sphagnum subnitens commonly has a strong red-purple color while S. subfulvum expresses this pigment much less frequently and less strongly, usually appearing quite brown or green.
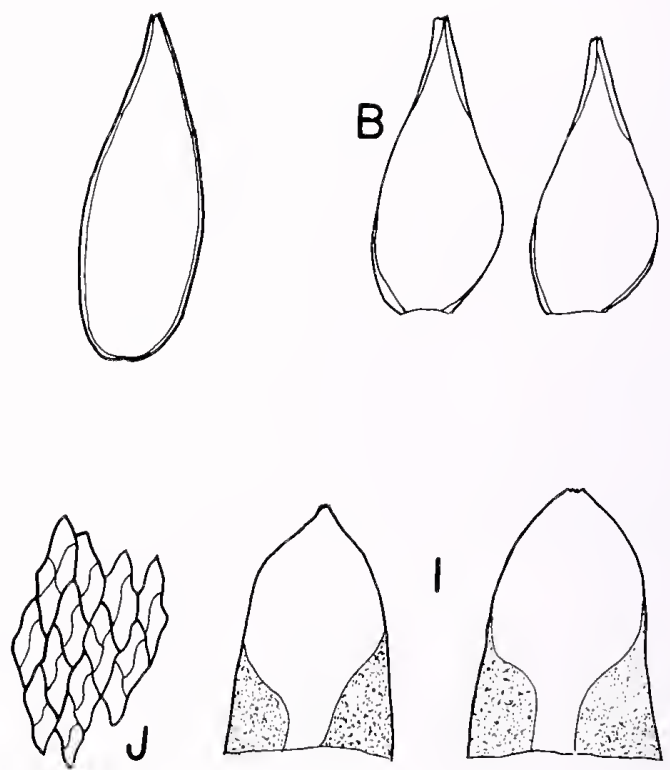


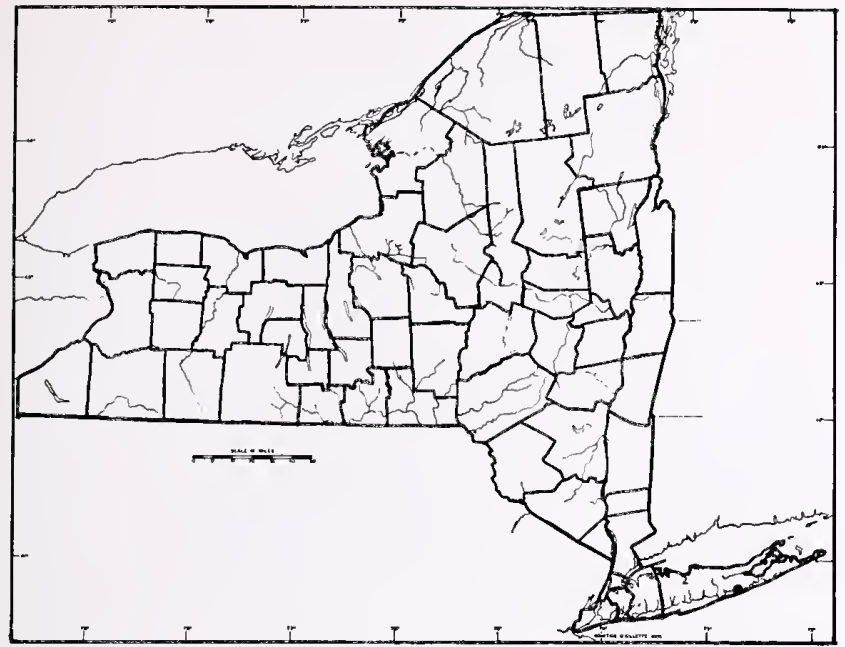

45. Sphagnum angermanicum Melin

Type Description: Melin, Svensk. Bot. Tidskr. 13:22, 1919.

Ecology: Minerotrophic and hydrophytic. A poor fen species (Maass, 1967), very hydrophytic for a member of the Acutifolia. Common associated species include S. papillosum, S. rubellum, S. flavicomans, S. imbricatum and S. pulchrum.

Habit: Plants of moderate size, soft and lax; capitulum large with head branches often distinctively blunt and transversely flattened. Forming carpets or low hummocks.

General Distribution: Amphiatlantic. In eastern North America near the coast, from Labrador to New Jersey.

Description: Stem pale green to purplish with the outer stem cortical layer occasionally porose; stem leaves large, broad, lingulate-triangular, widest at or above the middle, apex obtuse and dentate, border narrow and little broadened basally; hyaline cells narrowly rhomboidal to S-shaped, normally once divided, often fibrillose at the leaf apex; branch leaves large, ovate, imbricate, not 5-ranked, weakly involute apically, apex broadly truncate and bearing 6-10 conspicuous teeth; hyaline cells on the convex surface with elliptic pores along the commissures and on the concave surface with large round pores in the upper half and lower side regions; pigment purplish-red; plants usually pale green with a weak purplish coloration often evident in late summer and fall, often with a weak metallic lustre when dry.

Distinguishing Characters: Sphagnum angermanicum is a distinctive species apparently not closely related to others in section Acutifolia. Field recognition is made by the pale coloration, flattened head branches and soft texture. Microscopically, S. angermanicum is our only member of the Acutifolia having branch leaves

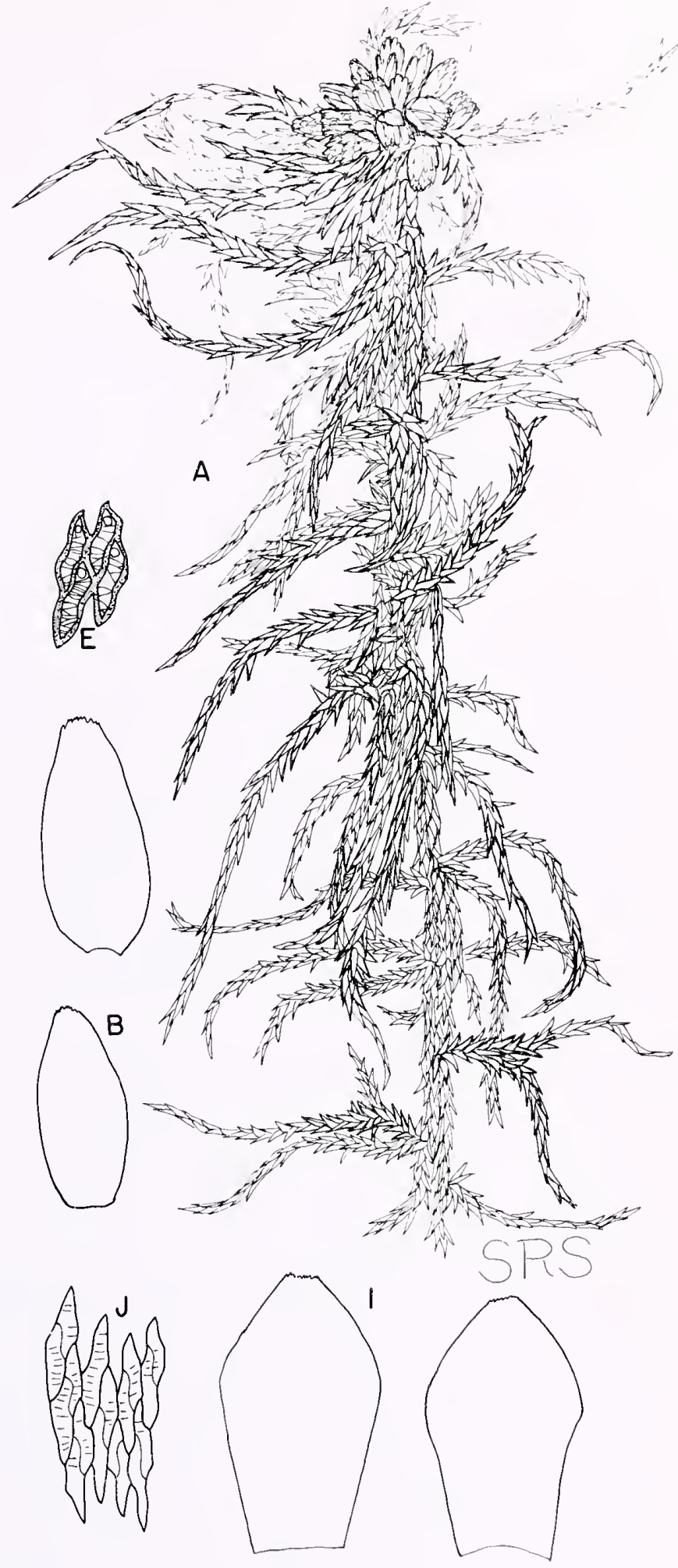


with both margins entire and with a conspicuously dentate apex. Sphagnum molle can appear superficially similar, but is clearly separable by its denticulate

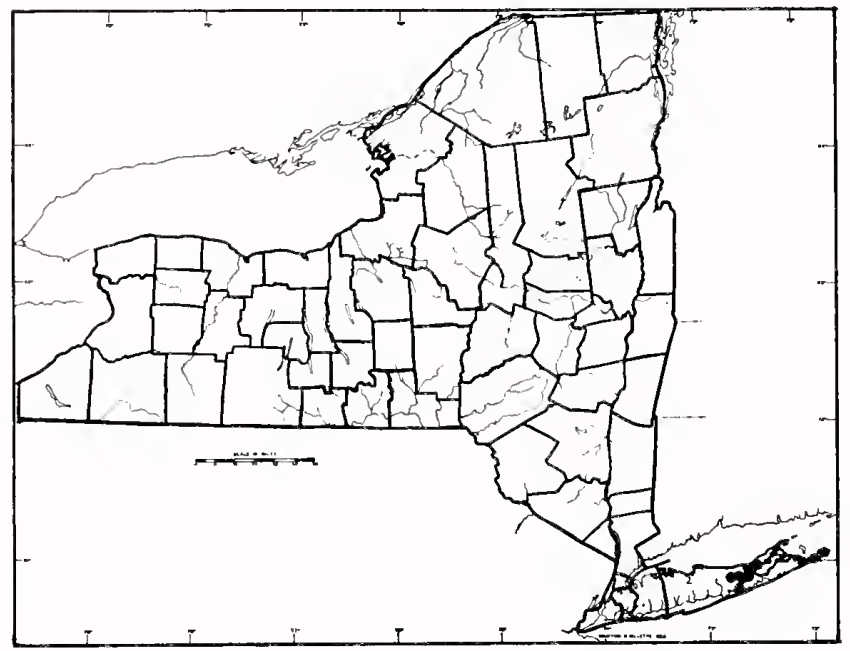

46. Sphagnum molle Sull.

Type Description: Sullivant, Musci Allegh. 205, 1845. Synonym: S. tabulare Sull.

Ecology: Weakly minerotrophic. Hygrophytic. Found on Long Island in poor fens among sand dunes, at margins of ponds and in abandoned cranberry bogs. Usually on sand, thin peat or muck, often where periodic desiccation is common.

Habit: Plants \pm moderate-sized, soft and lax when wet, stiff when dry, typically compact; capitulum flat and frequently large. Forming thin mats and occasionally low hummocks.

General Distribution: Amphiatlantic. Distributed in North America near the coast from Newfoundland south to Florida and across the Gulf Coast to Louisiana, and inland in the southern Appalachians to eastem Tennessee.

Description: Stem pale green to straw-colored; outer stem cortical layer aporose; stem leaves usually variable, elongate-lingulate to ovate, broadest above the middle, apex broad and toothed, border narrow and little broadened basally; hyaline cells narrowly rhombic, \pm fibrillose; branch leaves moderate-sized, ovate, stiffly involute, rarely 5-ranked and imbricate, spreading or subsquarrose, apex broadly truncate with up to 8 large teeth, border denticulate due to cell wall resorption and projecting cell walls; hyaline cells on the convex surface with elliptic pores along the commissures, grading from smaller pores at the leaf apex to large pores at the leaf base, the concave surface with large round pores in the lower side regions; pigment purplish-red; plants pale whitish, yellowish or purplish, rarely a deep purple-red. margined branch leaves. For a good discussion of $S$. angermanicum, see Maass (1967).

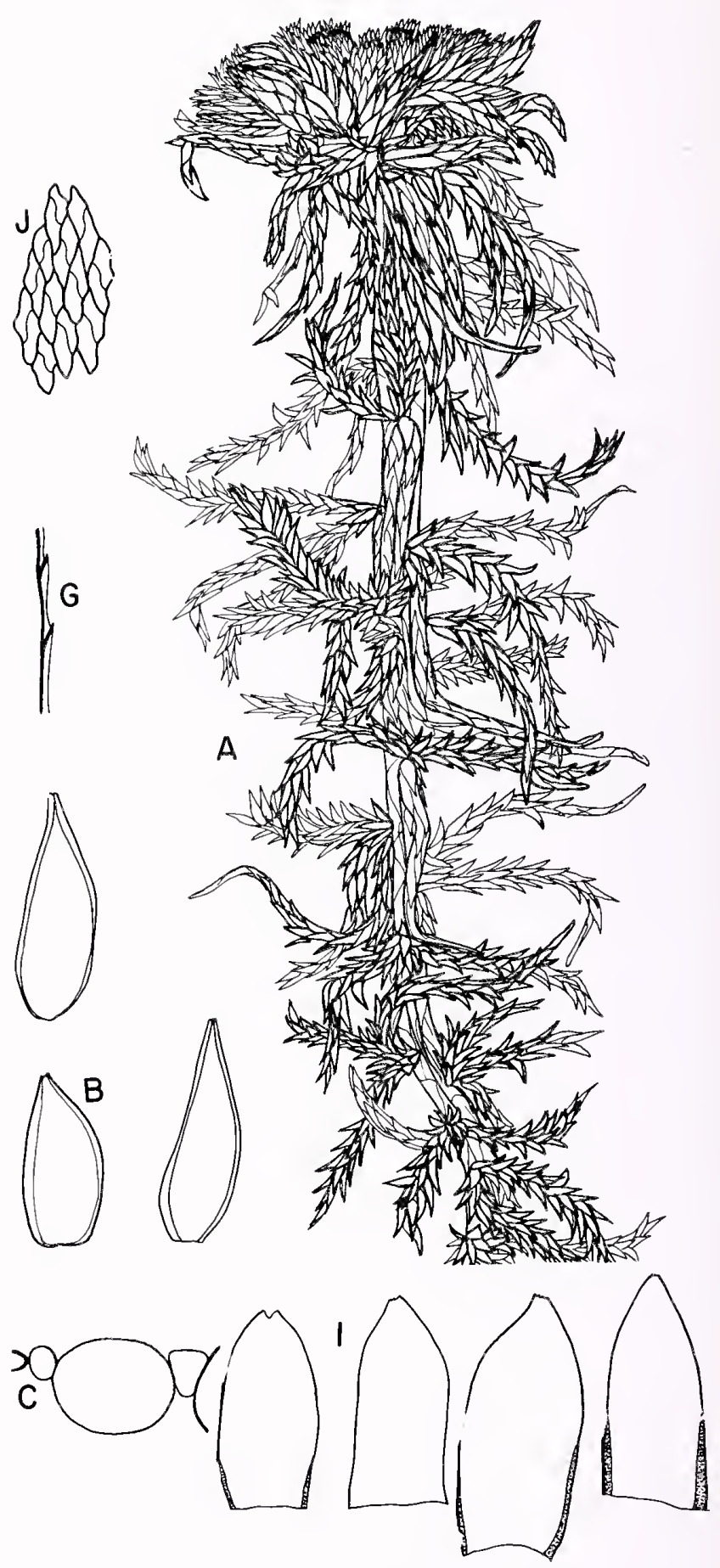


Distinguishing Characters: Sphagnum molle is our only species of Acutifolia with denticulate-margined branch leaves. On poorly developed plants the denticulations may not be clearly evident; on such forms, transverse sectioning of the leaf will reveal the resorption furrow.
Note: Sphagnum tabulare, the name most frequently used in America, was valid only under the old American Code.

\section{GLOSSARY}

anisophyllous. Having stem leaves unmodified by environmental stress and distinct morphologically from branch leaves. cf. pp. 23--26.

amphiatlantic. Distributed oceanically or suboceanically along both the North American and European Atlantic coasts.

amphipacific. Distributed oceanically or suboceanically along both the North American and Asian Pacific coasts. apiculate. Ending abruptly in a sharp point, as in leaf tips.

bog. A mire in which the water supply is strictly atmospheric; i.e., there is no mineral soil water influence. cf. fen. capitulum. The head of the Sphagnum plant, formed by densely packed newly developing branches.

carr. A Willow- or Alder-dominated minerotrophic mire, often adjoining a water course.

circumpolar. Continentally or widely distributed completely around the Northern Hemisphere.

comb-fibrils. Parallel, ridge-like growths on the branch leaf hyaline cell walls where they overlie chlorophyll cells. commissures. The seams along which leaf cells join.

continental. Distribution clearly concentrated toward the middle of continental land masses, though not necessarily completely limited to such areas.

cucullate. Curled over and appearing like a hood, as in the branch leaf apices of Section Sphagnum spp.

dentate. With strong outward-pointing teeth, as in leaf margins and apices.

denticulate. With small, weak, outward-pointing teeth, as in leaf margins.

crose. Margin appearing worn and irregular, as in stem leaves.

fen. Any peat-forming wetland whose water supply has at least some nutrient input from mineral soil water, i.e., a mire whose water supply is not completely atmospheric. cf. bog.

fimbriate. Margin fringed with cilia formed by projecting cell walls.

free pores. Pores positioned free of the commissures, especially in branch leaves.

hanging branches. See wick branches.

hastate. Arrowhead-shaped, with the basal flanges pointing outwards.

hemiisophyllous. Having stem leaves moderately modified by environmental stress and morphologically somewhat similar to branch leaves.

hydrolabile. Tending to form strong morphological and size variations in response to differing hydrologic regimes. cf. hydrostable.

hydrophytic. Typically found in very wet sites, often in carpets at or close to the water table. cf. hygrophytic.

hydrostable. Tending to maintain a stable morphology and size in response to hydrological stress. cf. hydrolabile. hygrophytic. Typically found in damp sites such as hummocks or carpets over moist humus. cf. hydrophytic.

involute. Lateral margins inrolled, especially in leaves.

isophyllous. Having stem leaves strongly modified by environmental stress and morphologically strongly resembling branch leaves.

lacerate. With an irregularly cut or torn appearance. 
minerotrophic. Characteristically associated with sites having a distinct input of dissolved minerals from soil water. Also used to refer to mires with such an input. cf. ombrotrophic.

mucronate. Ending in a short, abrupt point.

oligotrophic. Refers to ponds, lakes and mires with low amounts of dissolved nutrients.

ombrotrophic. Characteristically associated with sites having a nutrient input derived entirely or almost entirely from atmospheric sources. Also used to refer to mires with such an input. cf. minerotrophic.

pseudopores. Pore-like featured developed along the commissures in branch leaves, formed by extensions of the reinforcing fibrils that extend parallel to the commissures and perpendicularly between the fibril bands. cf. wallthinnings.

raised bog. A bog with a convex cross section, the center being higher than the margins. Characteristic of coastal areas with high precipitation and humidity.

resorbed (resorption, n.). Absent due to absorption by natural processes, especially in cell walls on either the convex or concave stem leaf surface of certain species.

resorption furrow. As seen in transverse section, a groove along the leaf margin formed by resorption of the hyaline cell walls.

retort cells. Branch cortical cells with conspicuous outward-pointing, open-ended necks.

serrate. With strong, sharp, forward-pointing teeth, especially in leaf margins.

serrulate. Serrate with fine teeth.

simplex. Lacking branches.

spreading branches. In a fascicle, those branches spreading outward from the stem. cf. wick branches.

subsimplex. With 1-2 branches per fascicle.

wall-thinnings. Pore-like structures formed by thinning of cell walls, sometimes termed shadow pores.

wick branches. In a fascicle, those branches hanging downward along the stem, also termed hanging branches.

widely distributed. Distribution not clearly concentrated either inland or along the coast. 


\section{LITERATURE CITED}

Abramova, L. A., L. I. Savich-Lyubitskaya and E. N. Smirnova, 1961. A Guide to the Leafy-stemmed mosses of the Aretic U.S.S.R. (transl. from Russian). Kamarov Bot. Inst.

Andrews, A. L., 1913. Order Sphagnales. Family 1. Sphagnaceae. North American Flora 15 (1):1-31. 1958. Notes on North American Sphagnum. Review. Bryologist 61:269-276.

Andrus, R. E., 1974. The Sphagna of New York State. Ph.D. Thesis, State Univ. New York, College of Environmental Science and Forestry, Syracuse, N.Y.

$83: 60-64$.

1980. Sphagnum andersonianum, a new species endemic to Northeastern North America. Bryologist

Anschutz, I. and F. Gessner, 1954. Des Ionenaustausch bei Torfmoosen. Flora, Jena 141:178-236.

Bendz, G., O. Martensson and $\mathbb{E}$. Nilsson, 1965. Moss pigments. III. Isolation of some reddish pigments from Sphagnum species. Ark. Kemi 25:215-221.

Broughton, J. G., D. W. Fisher, Y. W. Isachsen, and L. V. Rickard, 1966. Geology of New York: a short account. Educ. Leaflet No. 20, N.Y.S. Museum, Albany, N.Y. vi. + 50 pp.

Clymo, R. S., 1963. Ion exchange in Sphagnum and its relation to bog ecology. Ann. Bot. N.S. 27:309-324.

Conway, V. M., 1949. The bogs of central Minnesota. Ecol. Monogr. 19:173-206.

Coupal, B. and J. M. Lalancette, 1976. The treatment of waste waters with peat moss. Water Research 10:1071.

Craigie, J. S. and W. S. G. Maass, 1966. The cation exchanger in Sphagnum. spp. Amn. Bot. N. S. 30:153-154.

Crum, H. A., 1971. Nomenclatural changes in the Musci., Bryologist 74:165-174.

1975. Comments on Sphagnum capillaceum. Contr. Univ. Mich. Herb. 11:89-93.

1976. Mosses of the Great Lakes forest (rev.ed.) Univ. Mich., Ann Arbor, Mich.

Damman, A. W. H., 1977. Geographic changes in the vegetation pattern of raised bogs in the Bay of Fundy region of Maine and New England. Vegetatio 35:137-151.

1978. Distribution and movement of elements in ombrotrophic peat bogs. Oikos. 30:480-495.

1979a. Geographic patterns in peatland development in eastern North America. Proc. Int. Symp.

Classif. Peat and Peatlands, Int. Peat Soc., pp. 42-57.

1979b. Amphiatlantic correlations in the Oxycocco-sphagneta: a critical evaluation. Documents phytosociologiques, N.S. IV: $187-195$.

Dansereau, P. and F. Segados-Vianna, 1952. Ecological study of the peat bogs of eastern North America. I. Structure and evolution of vegetation. Can. Jour. Bot. 30:490-520.

DuReitz, G. E., 1949. Huvudenheter och huvudgranser i svensk myrvegetation (Main units and main limits in Swedish mire vegetation). Svensk Bot. Tidskr. 43:274-309.

1954. Die Mineral bodenwasserzeigergrenze als Grundlage einer natülichen Zweigleiderung der nord-und mitteleuropäischen Moore. Vegetatio 5--6:571-585.

Fenneman, N. M., 1938. Physiogeography of Eastern United States. McGraw-Hill Book Co., Inc. N.Y. and London xiii +714 pp. + VII pls.

Gorham, E., 1953a. Chemical studies on the soils and vegetation of waterlogged habitats in the English Lake District. Jour. Ecol. 41:345-360.

1953b. A note on the acidity and base status of raised and blanket bogs. Jour. Ecol. 41:153.

and W. H. Pearsall, 1956. Acidity, specific conductivity and calcium content of some bog and fen waters in northern Britain. Jour. Ecol. 44:129-141. 
Green, B. H., 1968. Factors influencing the spatial and temporal distribution of Sphagnum imbricatum Hornsch. ex Russ. in the British Isles. Jour. Ecol. 56:47-58.

and M. C. Pearson, 1968. The Ecology of Wybunbury Moss, Cheshire. I. The present vegetation and some physical, chemical, and historical factors controlling its nature and distribution. Jour. Ecol. 56:245-267.

Heinselman, M. L., 1963. Forest sites, bog processes, and peatland types in the Glacial Lake Agassiz Region, Minnesota. Eccl. Monogr. 33:327-374.

1970. Landscape evolution, peatland types, and the environment in the Lake Agassiz Peatlands Natural Area, Minnesota. Ecol. Monogr. 40:235-261.

Heising, L. F., 1974 (1977). The mineral industry in New York in U.S. Bur. Mines Minerals Yearbook, v. 2: 493-502 .

Hennezel, F. and B. Coupal, 1972. Peatmoss--a natural absorbent for oil spills. Can. Min. Met. Bull. 65:51-53.

Horikawa, Y. and H. Suzuki, 1954a. Ecological observations in the sphagna in the Oze district. Sci. Res. Ozegahara Moor: 498-536. Tokyo.

, 1954b. Sphagnum species in the Oze district. Jap. Jour. Bot. 14:325-348.

Huss, T., 1977. The cranberry bogs of Long Island. The Conservationist 32(6): 5-8.

Isoviita, P., 1966. Studies on Sphagnum L. I. Nomenclatural revision of the European Taxa. Ann. Bot. Fenn. 3:199-264.

Jeglum, J. K., A. N. Boissoneau and V. F. Haavisto, 1974. Toward a wetland classification for Ontario. Can. For. Serv., Sault Ste. Marie, Ont. Inf. Rep. O-X-215.

Kivinen, E., 1963 (1968). On the spread and characteristics of bogs in Finland. in Trans. Second Int. Peat Congr., Leningrad I: $15-26$.

Kurz, H., 1928. Influence of Sphagnum and other mosses on bog reactions. Jour. Ecol. 9:56-69.

Lange, B., 1955. Sphagnum tenerum Sull. and Lesq. and Sphagnum tenerum (Aust.) Warnst. Bot. Tidskr. 52:4347.

Maass, W. S. G., 1966. Untersuchungen uber die Taxonomie und Verbreitung von Sphagnum VI. Sphagnum pylaesii Brid. und das boreo-atlantische Florenelement unter den Torfmoosen in Sudamerika. Nova Hedwigia $\mathrm{Z}$. Kryptogamenka 12:81-105 + V pls.

1967. Studies on the Taxonomy and Distribution of Sphagnum II. Sphagnum angermanicum Melin on North America and its relation to allied species. Nova Hedwigia Z. Kryptogamenka 13:449-465 + Tbl. 116-128.

Malmer, N., 1959. De Svenska Sphagnum arternas systematik och ekologi. Rev. 1966 by Mats Sonesson. Mimeogr. paper, Lund, 46 pp.

1962, Studies on mire vegetation in the Archaen area of southwestern Gotaland (South Sweden). I. Vegetation and habitat conditions on the Akhult mire. Opera Bot. 7(1): $322 \mathrm{pp}$.

Mårtensson, O. and E. Nilsson, 1974. On the morphological color of bryophytes. Lindbergia 2:145-159.

Mickelsen, D. P., 1976. Peat. pp. 889-897 in Minerals Yearbook 1974. V. I. Metals, Minerals and Fuels. U.S. Bur. Mines.

Miller, H. M. S., 1963 (1968). Use of peat as a domestic fuel in Ireland. in Trans. Second Int. Peat Congr., Leningrad I: 471-482.

Miller, W. J., 1913. The Geological History of New York State. N.Y.S. Museum Bull. 168, 130 pp. +52 pls.

Moore, P. D. and D. J. Bellamy, 1973. Peatlands. Springer-Verlag, New York.

Mörnsjö, T., 1969. Studies on vegetation and development of a peatland in Scania. South Sweden, Opera Bot. 24:186 pp. + VIII pls. Lund.

Morris, R. B., 1977. Structural colour in the moss Sphagnum subnitens Russo and Warnst. Jour. Bryol. 1977: 387392.

Nyholm, E., 1969. Illustrated Moss Flora of Fennoscandia. II. Musci. Fasc. 6:647-799. 
Olenin, A. S., 1963 (1968). Peat Resources of the U.S.S.R. in Trans. Second Int. Peat Congr., Leningrad I: $1-14$. Osvald, H., 1955. The vegetation of two raised bogs in northeastern Maine. Svensk. Bot. Tidskr. 49:110-118.

Paton, J. A. and P. J. Goodman, 1955. The conditions promoting anthocyanin-formation in Sphagnum nemoreum Scop., Trans. Brit. Bryol. Soc. 2:561--567.

Pearsall, W. H., 1941. The "mosses" of the Stainmore district. Jour. Ecol. 29:161-175.

Persson, A., 1961. Mire and spring vegetation in an area north of Lake Tometrask, Torne, Lappmark, Sweden, Opera Bot. 6(1):187 pp.

Poots, V. J. P., G. McKay and J. J. Healy, 1976. The removal of acid dye from effluent using natural absorbents. I. Peat. Water Research 10:1061.

Ratcliffe, D. A. and D. Walker, 1958. The Silver Flowe, Galloway, Scotland, Jour. Ecol. 46:407-445.

Rigg, G., 1940. Comparisons of the development of some Sphagnum bogs of the Atlantic Coast, the interior, and the Pacific Coast. Amer. Jour. Bot. 27:1-14.

Rónning, O. I., 1958. Studies in Sphagnum molle Sull. and related forms. Acta Borealia A. Sci. 14:1-24.

Rose, F., 1953. A Survey of the ecology of the British lowland bogs. Proc. Linn. Soc. Lond. 164:186-211.

Roth, G., 1960. Die europaischen Torfmoose. Nachtrageheft zu den europäischen Laubmoosen. VIII + 80 pp. + XI pls. Leipzig.

Rudolph, H., 1964. Zur Frage der Membranechromie bei Sphagnen. Flora, Jena 155:250-293.

Sherrin, W. R., 1927. An illustrated Handbook of the British Sphagna. X + 74 pp. + VIII pls. London.

Sjörs, H. C., 1944. Sphagnum subfulvum n. sp. and its relations to S. flavicomans (Card.) Warnst. and S. plumulosum Warnst. Svensk. Bot. Tidskr. 38:403-427 + pls. VII-VIII.

$2: 241-258$

1950a. On the relation between vegetation and electrolytes in north Swedish mire waters. Oikos

1950b. Regional Studies in north Swedish mire vegetation. Bot. Not. 2:173-222.

1959. Bogs and fens in the Hudson Bay lowlands. Arct., Jour. Arct., Inst. North Am. 12:2-19.

1963. Bogs and fens on Attawapiskat River, northern Ontario. Can. Dept. N. Aff. Res., Nat. Mus.

Can. Bull. 186, Contrib. to Bot.: 45-133.

Smith, G. L., 1977. Sphagnum recurvum. Phytologia 36:171-176.

Spearing, Ann M., 1972. Cation-exchange capacity and galacturonic acid content of several species of Sphagnum in Sandy Ridge Bog, central New York State. Bryologist 75:154-158.

Suzuki, H., 1956a. Sphagnological notes on the Numanohara Moor of the Daisetsu Mountains of Hokkaido. Seibutsugakkaishi 7:4-8.

1956b. Variations in Sphagnum junghuhnianum var, pseudomolle Warnst. and the status of Sphagnum kiiense Warnst. Jap. Jour. Bot. 15:186-198.

1958. Taxonomical studies on the Subsecunda Group of the Genus Sphagnum in Japan, with Special reference to Variation and Geographical Distribution. Jap. Jour. Bot. 16:227-268.

1960. Collecting Sphagnum on Mt. Gassan, Yamagata Prefecture, northern Honshu. Hikobia 2:54-59.

Tansley, A. G., 1939. The British Islands and their vegetation. 930 pp. Cambridge.

Tsuprov, S. A. and A. A. Sokolov, 1963 (1968). Peat production in the U.S.S.R. in Trans. Second Int. Peat Congr., Leningrad. I: 241-248.

Vidal, H., 1963 (1968). Importance of northwestern and central European bogs as regulators of water balance and climate. in Trans. Second Int. Peat Congr., Leningrad I: 167-168.

Vitt, D. H. and R. E. Andrus. 1977. The genus Sphagnum in Alberta. Can. Jour. Bot. 55: 331-357.

D. H., H. Crum and J. A. Snider, 1975. The vertical distribution of Sphagnum species in hummockhollow complexes in northern Michigan. Mich. Bot. 14:190--200. 
Warnstorf, C., 1899. Neue Beiträge zur Kryptogamenflora der Mark Bradenburg. Verzeichnis der in der Niederlausitz beobachteten Moose nebst Kritischen Bemerkungen zu verschiedenen Arten, sowie Mitteilungen über neue Beobachtungen aus andered Teilen der Mark. II. Specieller Teil. Abh. Bot. Ver. Prov. Brandenb. 41:1980.

1911. Sphagnales-Sphagnaceae (Sphagnologia universalis). A. Engler (ed.), Das Pflanzenreich. Regni vegetabilis conspectus 51 . IV +546 pp. Leipzig.

Wetzel, R. G., 1975. Limnology. W. B. Saunders, Philadelphia.

Zerow, D., 1928. Die Torfmoose der Ukraine. Academie des Sciences de l'Ukraine. Memoires de la Classe des Sciences Physiques et Mathematiques. Tome X, livre 1 . 


\section{SPECIES INDEX}

Sphagnum

PAGE

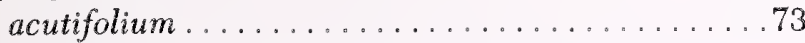

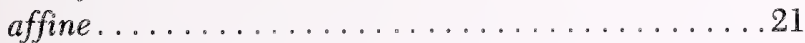

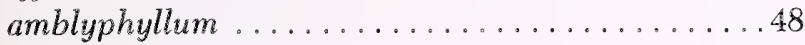

andersonianum.................... 70

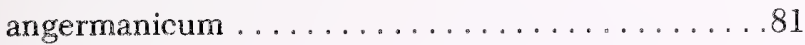

angustifolium $\ldots \ldots \ldots \ldots \ldots \ldots \ldots \ldots \ldots \ldots$

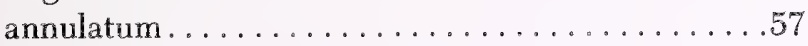

apiculatum ....................... . . .

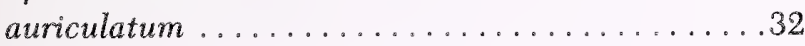

austinii ........................21

bartlettianum ....................67

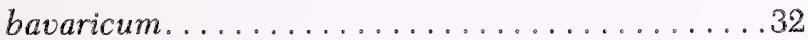

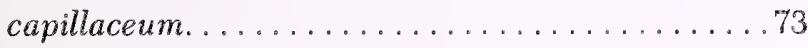

capillifolium .................... 73

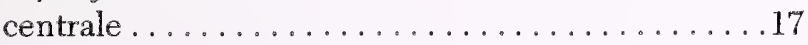

compactum .......................24

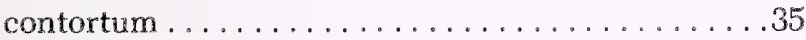

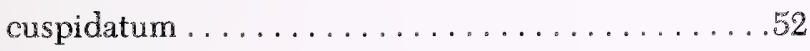

cyclophyllum $\ldots \ldots \ldots \ldots \ldots \ldots \ldots \ldots \ldots \ldots . \ldots \ldots \ldots$

cymbifolium ..................... 18

dusenii........................56

fallax...........................51

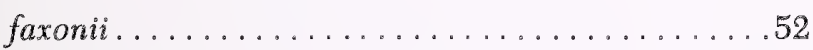

fimbriatum ......................63

flavicomans ......................... . . . . .

flexuosum . . . . . . . . . . . . . . . . . .48

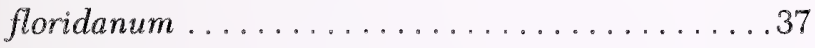

fuscum.........................

garberi........................25

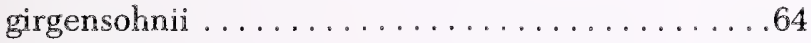

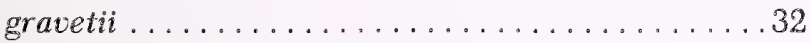

henryense ......................... 19

imbricatum ....................21

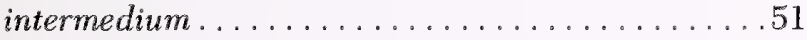

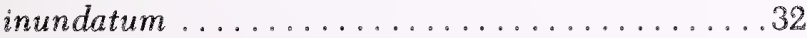

jensenii . ......................... 57

kearneyi ......................52

laxifolium .........................

lenense .......................43

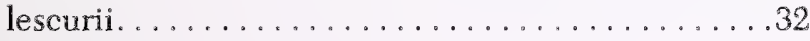

lindbergii.......................43

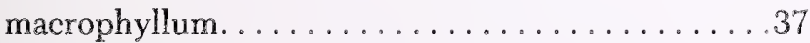

magellanicum ......................... 16

majus ..........................56

medium ...........................16 molle ..........................., 82

molluscum......................42

mucronatum ......................51

nemoreum......................73

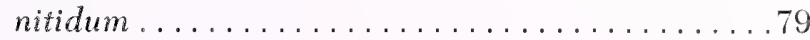

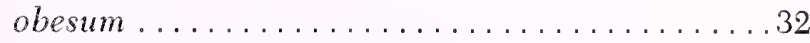

obtusum ..........................58

palustre ........................... 18

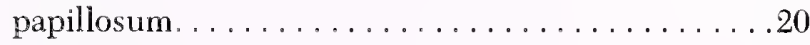

parvifolium......................... 49

perichaetiale......................21

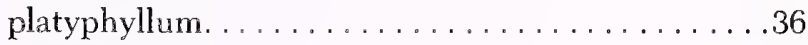

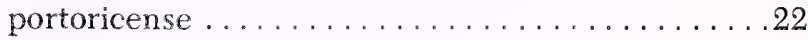

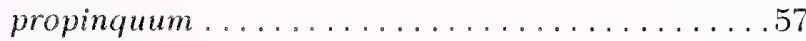

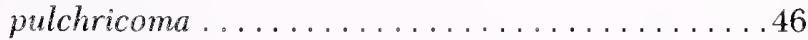

pulchrum........................... 45

pylaesii ............................

quinquefarium ...................... 67

recurvum. ......................46

rigidum ............................24

riparioides.......................46

riparium ..........................

robustum..........................65

rubellum ........................68

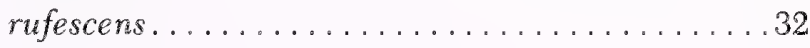

russowii .........................65

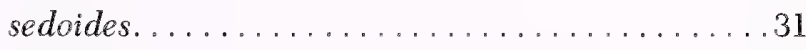

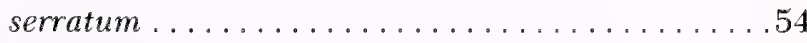

squarrosum.......................28

strictum...........................25

subbicolor......................... 18

subfulvum ........................79

subnitens.......................80

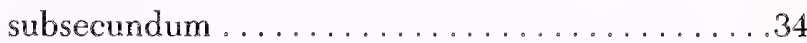

subtile ..........................72

sullivantianum .....................22

tabulare. . . . . . . . . . . . . . . . . . . . .82

tenellum .........................42

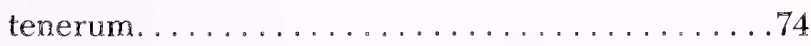

tenuifolium ......................... 70

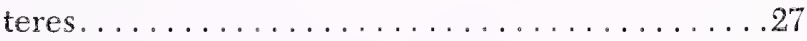

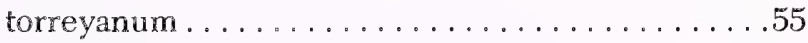

trinitense........................ . . . .

virginianum $\ldots \ldots \ldots \ldots \ldots \ldots \ldots \ldots \ldots \ldots \ldots \ldots \ldots$

warnstorfianum ...................66

warnstorfii. . . . . . . . . . . . . . . . .66

wulfianum .......................58 



\section{Contributions Completed to Date ${ }^{1}$}

1. Mitchell, Richard S. and J. Kenneth Dean. 1978. Polygonaceae, (Buckwheat Family) of New York State. Contributions to a Flora of New York State I. N. Y. State Museum Bull. No. 431, 81 p.

2. Mitchell, Richard S. and Ernest O. Beal. 1979. Magnoliaceae through Ceratophyllaceae of New York State. Contributions to a Flora of New York State II. N. Y. State Museum Bull. No. 435, 62 p.

3. Ketchledge, Edwin H. 1980. Revised Checklist of the Mosses of New York State. Contributions to a Flora of New York State, Checklist I. N. Y. State Museum Bull. No. 440, 19 p.

4. Andrus, R. E. 1980. Sphagnaceae (Peat Moss Family) of New York State.

Contributions to a Flora of New York State III. N. Y. State Museum Bull. No. 422, 89 p.

${ }^{1}$ To purchase copies of these publications, contact: 


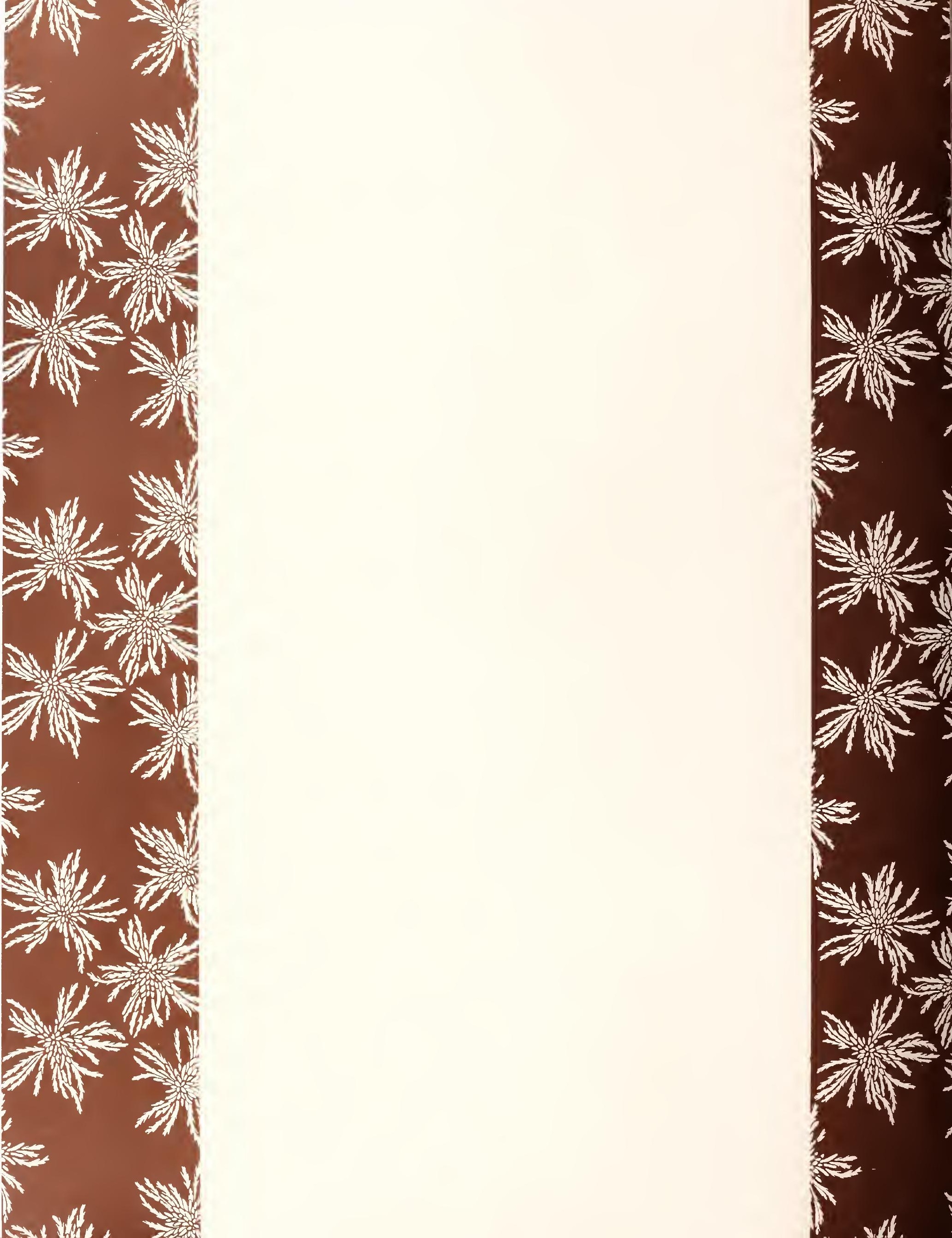

